\title{
COAL, LIGNITE, AND PEAT.
}

\section{SURVEY WORK ON COAL DURING 1905.}

\author{
By Marius R.. Campbel.
}

\section{GENERAL STATEMENT.}

Coal is by far the most valuable mineral product of the United States. According to the statistics of production for 1904, a the four mineral-products which stand highest in the list of values are as follows:

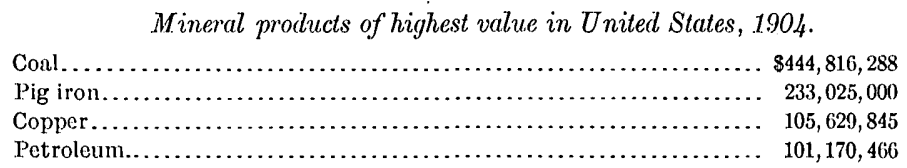

Although in 1904 the production of coal was not quite equal to that of the preceding year, greater activity than in any previous year was manifest throughout the country in prospecting and developing new fields, and in efforts to determine better methods of utilization.

This was largely due to the establishment of a coal-testing plant at St. Louis, for which Congress appropriated the sum of $\$ 60,000$. The interest taken in this work by coal operators, coal consumers, and the general public shows plainly that the people are keenly alive to anything that tends to the cheaper production and the better utilization of the fuels of the country.

The immcdiate results obtained during 1904 resulted in an appropriation for 1905 amounting to $\$ 202,000$ for the continuation of the coal-testing work, and incidentally an increase was made in the appropriation for geologic work of the Survey, with the express provision that this increase should bo used in the investigation of the fuel resources of the country.

In order to carry out the intention of Congress, a committee was appointed by the Director of the United States Geolological Survey to consider the best methods of exploiting the fuel resourcs of the country, and also methods for their better utilization. This committee consists of Dr. C. W. Hayes, gaologist in charge of geology; Prof. J. A. Holmes, superintendent of the coal-testing plant; Mr. E. W. Parker, statistician, and Mr. M. R. Campbell, geologist. The members of this committee represent the varied phases of fuel work carried on by the Geological Survey, and their office is to advise and direct the work so as to cover the entire ground of geologic occurrence, utilization, and statistics of production.

\section{GENLOGIC WORK OF rgo5.}

The geologic work on the coals was placed under the general direction of the writer, and plans were at once made for the continuation of systematic detailed work in the old and well-known coal fields of the East and of special reconnaissance surveys in the westen fields.

Pennsylvania.-In the eastern part of the United States geologic work was carried on as usual in the bituminous-coal field of Pennsylvania, in cooperation with the State authorities. Under this arrangement three 15-minute quadrangles, the Newcastle, Claysville,

\ Mineral Resources U. S. for 1904, U. S. Geol. Survey, 1905, pp. 32, 33. 
and Punxsutawney, covering a territory of about 750 square miles, were surveyed by George H. Ashley, who was assisted by Frank W. De Wolf, Frederick B. Pcck, and M. J. Munn. In this region the coals are fairly well known and little information regarding new seams or new territory was developed. The object of the work was to determine the cxact correlation of the various beds, the extent of the workable areas, and the geologic structure of the field. The latter was perhaps the most important object, since it not only has a direct bearing on the commercial development of the coal, but also on the accumulation of oil and gas, for which this region is particularly noted.

Kentucky.-In northeastern Kentucky the Kenova quadrangle was thoroughly investigated by W. C. Phalen, under the dircetion of G. H. Ashley, and the geologic relations of the coal beds were studied and mapped with considerable detail. The area examined is embraced in a 30 -minute quadrangle, and covers approximately 950 square miles. In this region the main object of the work was to trace the outcrop and to correlate the various coal and clay beds, also to determine the thickness and extent of the workable parts of the beds and the general structure of the region.

Alabama.-In the southern Appalachians work of a similar detailed character was carried on by Charles Butts in the coal field near the city of Birmingham. In this region one 30 -minute quadrangle in the vicinity of Birmingham was mapped, with the exception of the southeast corner. The territory examined lay mostly in the Big Warrior coal field, and the coal saams were very carefully examined and plotted on the map. Correlations were made and also accurate determinations of the extent and quality of the workable coal.

No work was done in the coal fields of the Mississippi Valley during the past year.

New Mexico-Colorado.-In the Rocky Mountain region a number of parties were at work making reconnaissance surveys of some of the little-known coal fields. In southern Colorado and northwestern New Mexico F. C. Schrader, assisted by M. K. Shaler, made a reconnaissance examination of about 2,050 square miles of territory. This party began operations at Durango, Colo., following the outcrop of the coal-bearing rocks to the east and south into the Mount Taylor region of New Mexico, and then swinging to the west and following in a general way the outcrop of the coal beds to Gallup, N. M., where there are several large mines in operation. For a number of years this field has been attracting attention and numerous railroad surveys have been made across it, presumably with the intention of developing its coal resources, but so far little practical development has occurred, except in the vicinity of Gallup, on the Santa Fe Railway, and around Durango and Monero, on the Denver and Rio Grande Railroad. During the past year a branch of the latter system has been built south from Durango to San Juan River, affording access to a very important part of this coal field. The work done by Schrader's party consisted in determining the areal distribution of the coals, correlating the beds worked at the various points, and determining the geologic horizons at which the coal occurs.

Colorado.-In the northwestern part of Colorado the Yampa or Routt County coal field has likewise attracted great attention for a number of years. Surveys have been made into the region by the Union Pacific Railroad and the Burlington System, but up to the present time no line has been constructed, and consequently the field has remained in an undeveloped condition. Recently public attention has been directed to this field through the building of the Denver, Northwestern and Pacific Railroad from Denver into Middle Park and its projection to the west down Yampa Valley. In order to meet the demand for reliable information regarding the coal of the Yampa field, a careful reconnaissance survey was made by N. M. Fenneman and H. S. Gale, assisted by R. C. Allen. A very detailed reconnaissance examination was made of a territory covering about 1,200 square miles along Yampa River, from a few miles below Steamboat Springs to the small village of Lay, near the center of the county. The feature of this field that has attracted the most attention is the occurrence of anthracite in the northern part, and some controversy has been carried on regarding the extent and value of these deposits. Considerable time was spent in an examination of this small anthracite area, in the hope that sufficient evidence might be obtained to determine its extent and commercial value, but owing to the broken condition 
of the conl-bearing rocks and the presence of considerable intrusive material, a great amount of surface wash, and a heavy covering of timber, it was almost impossible to determine the areal extent of metamorphism without thorough prospecting with the drill. There is no doubt that a good quality of anthracite occurs in this area, but until prospecting has been done there is great uncertainty regarding its geographic extent. The local character of the metamorphism of the coal makes it seem doubtful whether this area will ever be of very great commercial importance, bat the field as a whole is undoubtedly very important, since there are a number of thick seams of good bituminous coal throughout its extent. This alone, will amply repay development. Beyond the territory covered by this reconnaissance the coals are lignitic and of much poorer grade than they are in the territory surveyed.

North Dakota-Montana:-In view of the rather extrnordinary results obtained at the coal-testing plant in making producer gas from brown lignite of North Dakota, it seemed desirable to determine more fully than heretofore the extent of such deposits in North Dakota and eastern Montana. For this purpose A. G. Leonard, assisted by Innis Ward and H. L. McDonald, made an examination of the country along Little Missouri River, from the crossing of the Northern Pacific Railway into South Dakota. They also examined the territory west of the Little Missouri between that and Yellowstone River and up the latter stream as far as Miles City, obtaining a large amount of information on the occurrence of workable beds of lignite and the general question of correlation with other parts of the field. In this region there are some thick beds of lignite, but they occur as lenticular masses, frequently having an area of only a few square miles and sometimes only a few acres. They are so common, however, that almost every section contains a bed of workable thickness. The work done in this region shows that similar conditions prevail over the western half of North Dakota and a large area in the southeast corner of Montana: At the present time there is little demand for these lignites, but with the simplification of the producergas apparatus and gas engine, the production of power from brown lignite will doubtless be attempted in many places. The tests $a$ show that in the producer plant 3.47 pounds of Williston brown lignite were required to produce one electrical horsepower per hour, while in the steam plant it required 3.40 pounds of the best West Virginia steam coal to produce the same result. This shows that the brown lignite, though containing practically 40 per cent of water as it was fired in the producer, is almost as valuable for the production of power as the best West Virginia coal used under the steam boiler. When this method of production of power comes into common use doubtless it will bring new industries into the Dakota country and stimulate those that have already obtained a foothold. The lignitebearing beds are not limited to the area just described, but extend indefinitely to the southwest and presumably are connected with the Sheridan field at the base of the Bighorn Mountains.

Wyoming.-The coal fields of Wyoming are among the more important ones of the Rocky Mountain States. Published data regarding some of them are available. Many of the others; though fairly well developed, have never been described. This is the case of the Hams Fork field, which lies in the southwestern part of the State. A survey of this interesting field was made during the past season by $A$. C. Veatch, assisted by Alfred R. Schultz. That part of the coal field covered by this survey has an area of 700 square miles, extending from a line somewhat north of the Oregon Short Line Railway in the vicinity of Kemmerer southward to the Utah line. Much data had already been obtained by the systematic prospecting of private parties in the region, and consequently the most important part of Veatch's work was the determination of the horizons of the various conl beds, the geologic structure, and the amount of unclaimed coal lands in this field. The report shows that it still contains a large acreage of Government land which can be entered as coal lands. A small oil field, known as the Spring Valley field, was also thoroughly examined and a corisiderable amount of new data on it was obtained.

Utah.-Geologic work was also carried on in the coal fields of Utah, which have long been :ecognized as among the most important in the West, but regarding which little published 
information is available. Considerable prospecting has been done, and large mines have been developed by the Utah Fuel Company at Castle Gate, Winter Quarters, Clear Creek, and Sunnyside.

The outcrop of the coal-bearing rocks shows continuously from Grand Junction, Colo., westward into Utah, in what is generally known as the Book Cliffs. This outcrop crosses the line of the Rio Grande Western Railway at Castle Gate, and at that point a large mine has been in operation for a number of years. West of Castle Gate the outcrop swings to the south along the eastern front of the Wasatch Plateau. Some development has taken place along this line to the south, and also to the north in an isolated field in the vicinity of Coalville, where considerable mining has been done.

During the past year J. A. Taff, assisted by C. D. Smith, made a reconnaissance of most of this territory, giving particular attention to the Book Cliffs field. This was done for the purpose of determining the number and extent of the workable beds, the quality of the coal, and the amount of coal land still unclaimed.

Other fields.-In addition to the work already mentioned, which was done expressly for the purpose of determining the extent of the fuel resources of the country, surveys were made of coals in other fields in the course of general geologic work. This was particularly the case in Wyoming, where C. A. Fisher obtained valuable information on the coals of the Bighorn basin; in New Mexico, where Willis T. Lee obtained data on the scattering coal fields of the central and southern part of the Territory, and in Utah, where G. B. Richardson obtained information on similar outlying fields in the central part of the State.

\section{WORK OF THE FUEL-TESTING DIVISION.}

The plan for the work of fuel testing was originally proposed by Prof. J. A. Holmes, chief of the mines and metallurgy department of the Louisiana Purchase Exposition, but the actual work of building up the plant and carrying on the tests for the first year was done by a committee. Th:s committee was appointed by the Director of the Geological Survey and consisted of E. W. Parker, J. A. Holmes, and M. R. Campbell.

The conditions imposed by the act of Congress under which this work was done were that all the apparatus and material to be tested should be supplied free of charge to the Government, but even with this restriction and the small appropration available a fairly efficient plant was established on the exposition grounds, with facilit:es for making chemical tests, washing tests, steaming tests, coking tests, briquetting tests, and producer-gas tests. Each of these lines of work was placed under a man who had made a specialty of work of this sort and was considered an expert. The plant was run continuously from about September 1, 1904, until January 1, 1905, and, after a shut down of a few months for alterations and repairs, was again put in operation in the spring of 1905 . A preliminary statement of the first season's work was published several months ago as Bulletin No. 261 of the United States Geological Survey, and a more detailed report of that work has just been issued (Professional Paper No. 48).

Of the general results it is not necessary here to speak, but it seems desirable to call attention to the geologic bearing of the work. This may be divided into two parts-first, that which concerns the chemical composition of the coal; and second, the geographical distribution of the samples that were tested and their representative character.

CHEMICAL WORK.

The chemical work of the coal-testing plant was placed in charge of Prof. N. W. Lord, of the Ohio State University, Columbus, Ohio. Professor Lord has probably done more original work on the chemical composition of coals than any other man in the country, and the committee was extremely fortunate in being able to secure his services.

Sampling.-Samples were taken not only of the carload of coal when it reached St. Louis, but also of each individual lot as it was tested in the var:ous departments. Two mine samples were also taken in the mine from which the carload was derived. This was done practically for all samples tested, and the result is a great mass of chemical data, showing the 
composition of the coal as it was sumpled under various conditions. Proximate analyses were made of all of these samples and one ultimate anilys $\mathrm{s}$ for each carload that was tested. These analyses provided material for study regarding, first, the different modes of sampling, and second, the chemical composition of the coal. It is the first instance in this country where a like number of ultimate analyses has been made. In fact, it is almost the only case in which such work has been done, especially on such a var:ety of coals, and the resulting data afford a most valuable basis for generalizations regarding the questions of coal compi... sition and origin.

One result of th's work was a paper by the writer on "The commercial value of coal-mine sumpling," $a$ in which the data derived from the analyses just mentioned. were compared and some very important conclusions were reached regarding the value of coal-mine sampling, especially with reference to the impurit:es, such as mo:sture, ash, and sulphur. It was found that the moisture in the car sample as it reached St. Lou:s in general was about the same as that originally contained in the coal of the coul bed, as shown by the analyses of the mine samples, which were sealed in air-tight galvanized-iron cans as soon as collected. 'The sulphur and ash, however, were different, and in the great majority of cases were much greater in commercial coal than in the mine samples. This s.mply means that in cutting the mine samples more care was exercised in cxcluding impurities than was done by the miners in the ordinary course of mining and loading coal.

The experience ga ned by th.s work seems to show that it is pract:cally impossible to make the two kinds of samples agree. Hence coefficients of increase were determined for the 50 samples that were tested. In the case of sulphur the amount in the car'samples in genc:al was found to be 1.04 times the amount in the mine samples, and consequently to obtain the amount of sulphur in commercial coal the amount shown by the mine analys.s should be multiplied by the coefficient 1.04. Similarly, the amount of ash in the car samples was found to be in general 1.3 times the amount shown in the mine samples. Therefore, to obtain the amount of ash in commercial coal the amount as shown by the analysis of the mine sumples should be multiplied by 1.3. Heretofore there has been no such determination of the general relation between impurities in mine samples and in commercial coal, and analyses made of mine samples have generally been accepted as ind.cat:ng the commercial value of any given coal. The results of this work show that such a determination is subject to very grave errors and that in general the ash and sulphur so determined should be multiplied by some such coefficients as those given above.

The general conclusions regarding the value of mine sampling were expressed as follows:

As already stated, the rules and regulations adopted for mine sampling in this work aimed to secure samples which would correspond with the commercial product of the mine. The results show that this was not attained, and, furthermore, they show that a strong personal element necessarily comes in where certain things are left to the judgment of the sampler. Such a system may be fairly satisfactory where one man does all the sampling. but this is seldom possible. In the light of the results obtained in this work it seems to me that some arbitrary system that will eliminate the personal equetion entirely is much better for general work, and therefore I recommend the following method of mine sampling:

Proposed method of mine sampling.-1. Select a fresh face of coal, and clean it of all powder stains and other impurities.

2. Cut a channel perpendicularly across the face of the coal from roof to floor, with the exceptions noted in 3 , of such a size as to yield at least 5 pounds of coal per foot of thickness of coal bed; that is, 5 pounds for a bed 1 foot thick, 10 pounds for a bed 2 feet thick, 20 pounds for a bed 4 fect thick, etc.

3. All material encountered in such a cut should be included in the sample, except partings or binders of more than 0.25 inch in thickness and except all lenses or concretions of sulphur or other impurities greater than 2 inches in maximum diameter and 0.5 inch in thickness.

4. The sample may be sent to the laboratory as it is cut, or it may at once be quartered down to about the size of aquart. If it is quartered down it should be pulverized to about three-eighths of an inch, and after thorough mixing it should be divided in to quarters and opposite quarters rejected. The operation of mixing and quartering should be repeated until the desired size of sample is obtained. The operation of pulverizing and quartering should be done as rapidly as possible, so as to prevent a serious change in the moisture content, and then the sample should be sealed in either a glass jar or screw-top can, bound with tire tape, and sent to the laboratory for analysis.

5. The analysis of such a sample will show the grade of conl that may be obtained by careful mining and picking. In the majority of cases the sulphur and ash in the commerical output of the mine will

a Trans. Am. Inst. Min. Eng., Washington meeting, May, 1905.

Bull. 285-06-14 
exceed thanount obtained from the sample, lut this can be approximated by multiplying by certain coefficients. The coeflicients determined in the work of the Geological survey coal-testing plant last year will not be strictly applicable, since the sampling was not done under this system, but they are approximately the same and can be used until more accurate coefficicnts ard determined. When sufficient data are at hand, it seems possible that specific coefficients may be determined for certain fields; that is, a coefieient for the A ppalachian field, another coefficient for the Eastern Interior ficld, etc., and, finaliy, coefficients may be determined for local subdivisions of the larger fields or for certain beds of coal within those fields.

6. All descriptions of samples should state definitely how the samples were obtained, so that the reader may judge for himself the value of the results obtained; and when analyses are recalculated the coefficients of increase or decrease should be given, together with the authority for using this coefficient or the data on which it was determined.

\section{CLASSIFICATION OF COALS.}

The material made available by the work of the chemical laboratory led to another line of investigation-that is, the classification of coals. It has been generally agreed that proximate analyses aflord no adequate basis for classification, though such a basis was proposed for the Pennsylvania coals many years ago. This, however, failed when it was applied to the lignitics and low-grade bituminous coals.

As a result of the work of the coal-testing plant there became a vailable fifty-six ultimate analyses of coals of all clisses from brown lignite to anthracite, and this seemed to aflord a favorable opportunity for an attempt at classification. After various trials the ratio of the carbon to the hydrogen seemed to present the best basis for a classification. This ratio runs from 26.7: 1 in Pennsylvania anthracite to 9.4:1 in Texas brown lignite. With the data available it seems as if cleven groups may be recognized and separated by such a scheme of classification, as follows:

$$
\text { Groups } A, B \text {, and } C \text {. }
$$

Carbon-hydrogen ratio.

Graphite and anthracites (only one representative-Pennsylvania anthracite) ......... 26.7

Group D.

Semianthracite (not represented).

$$
\text { Group } E \text {. }
$$

Semibituminous (only one representative-highest class A rkansas coal) $\ldots \ldots \ldots \ldots \ldots \ldots \ldots$

Group $F$.

Highest graḍe bituminous (best West Virginia and western $A$ rkansas coals)

Group $G$.

Second-grade bituminous (second-class West Virginia, first-class Kentucky and Alabama coals)

Group H.

Third-grade bituminous (first-class Indian Territory, Kansas, Missouri, Iowa, and Illinois

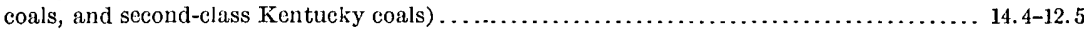

\section{Group 1.}

Lowest grade bituminous (includes majority of Iowa, Missouri, Illinois, and Indiana coals and some of the Wyoming and Montana coals)...

Group $J$.

Lignite (includes all lignites, both brown and black, that were tested) $11.2-9.3$

Group $K$.

Peat

It is not expected by the writer that such a classification will ever be used in a commercial way. The trade names are now well established, and it is not feasible to attempt to replace them by such a scientific classification as the above. There is, however, demand for just such a classification to definitely fix the position and the relative value of a coal. For instance, if the ultimate analysis of a sample of coal shows a carbon-hydrogen ratio of 14:1, 
the place of the coal in the above scheme of classification is definitely fixed, and in a general way, impurities being excluded, the true value of the coal is also fixed. The groups proposed are put forward tentatively. From the analyses at hand they, seem to represent all the grades of conl with which wo are acquainted, but it is possible that with further data the limits of the groups may be changed to some extent. It is not probable, however, that this change will be serious, and it is hoped that the limiting figures as given will stand.

There is no sharp separation between the lignites and the lowest grade bituminous coals, but the above grouping probably represents the facts in the case. It is possible, however, that in future work the carbon-hydrogen ratio of some ligintes may be slightly higher than that of some bituminous coals. It is anticipated that there will always be a certain amount of merging along this line, but according to the present scheme the lignites fall within one general group, and hence it seems to apply to them as well as to the bituminous coals.

\section{GEOGRAPHIC DISTRIBUTION OF SAMPLES.}

The geologist is more or less interested in the question of what coals were tested and how well the samples represent the entire coal fields of the United States. It is difficult to show in a brief way these facts. The following table gives the distribution of the samples which had been tested up to January 1, 1906, and these are compared with the production of the various States for the year 1904 and also with the estimated area of the coal fields within the various States:

Comparative table shoiving production, number of tests, and area of' coal, fields of the various States.

\begin{tabular}{|c|c|c|c|}
\hline State. & $\begin{array}{l}\text { Production } \\
\text { in } 1904 .\end{array}$ & $\begin{array}{l}\text { Number } \\
\text { of mines } \\
\text { sampled. }\end{array}$ & $\begin{array}{l}\text { Estimated } \\
\text { area of } \\
\text { coal fields. }\end{array}$ \\
\hline & Short tons. & & Sq. miles. \\
\hline Alabama......... & $11,262,046$ & 2 & 6,000 \\
\hline 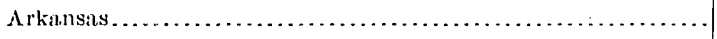 & $2,009,451$ & 4 & 2,500 \\
\hline 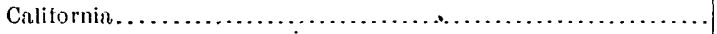 & 78,888 & 1 & 200 \\
\hline 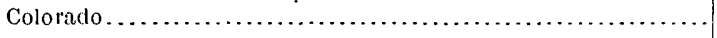 & $6,658,355$ & 1 & 7,000 \\
\hline Georgiu.......... & & & 167 \\
\hline North Carolina............ & 390,191 & 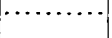 & 150 \\
\hline 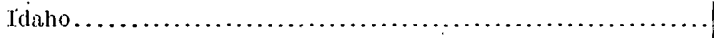 & 3,480 & ......... & $\ldots \ldots \ldots$ \\
\hline Illinois............ & $36,475,060$ & 12 & 42,900 \\
\hline Indiann $\ldots . . . \ldots \ldots \ldots \ldots$ & $10,934,379$ & 11 & 6,500 \\
\hline Indian Territory .......... & $1,046,539$ & 6 & 17,000 \\
\hline lowa $\ldots \ldots \ldots \ldots \ldots \ldots . . . .$. & $6,519,933$ & 5 & 10,000 \\
\hline 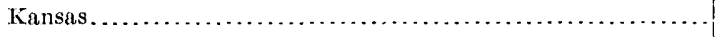 & $6,333,307$ & 5 & 15,000 \\
\hline Kentucky ................. & $7,566,482$ & 8 & 16,980 \\
\hline Maryland ................... & $4,813,622$ & & 450 \\
\hline Michigan ............... & $1,342,840$ & & 7,500 \\
\hline Missouri................ & $4,168,308$ & 4 & 14,000 \\
\hline Montana.............. & $.1,358,919$ & 1. & 32,000 \\
\hline New Mexico.................... & $1,452,325$ & 2 & 2,700 \\
\hline 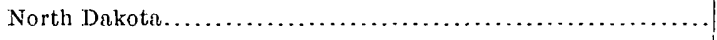 & 266,128 & 3 & 28,620 \\
\hline 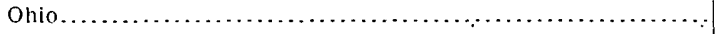 & $24,434,812$ & 8 & 12,000 \\
\hline 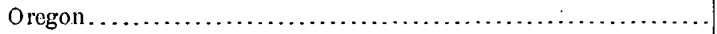 & 111,540 & & 300 \\
\hline Pennsylvania............ & $97,952,267$ & 8 & 12,200 \\
\hline Tennessee................ & $4,782,211$ & $\ldots \ldots \ldots$ & 4,400 \\
\hline 'l'exns........... & $1,195,944$ & 2 & 35,000 \\
\hline 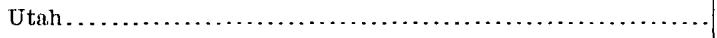 & $1,493,027$ & $\ldots \ldots \ldots$ & 2,500 \\
\hline Virginia................ & $3,583,914$ & 4 & 1,550 \\
\hline 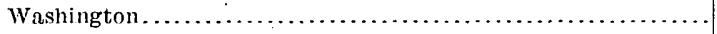 & $3,137,681$ & $\ldots \ldots \ldots$ & 100 \\
\hline West Virginia................ & $32,602,819$ & 21 & 24,780 \\
\hline Wyoming . . . . . . . . . . . . & $5,178,556$ & 2 & 8,000 \\
\hline
\end{tabular}


GENERAL RESULTS.

In addition to the above chemical and geologic data obtained by the coal-testing plant, it is desirable to call the attention of geologists to a new and improved method, developed during the course of this work, of utilizing coal in the production of power. This method consists of the conversion of the coal into producer gas and the use of this gas in an explosive gas engine. A brief preliminary statement of the results of these tests has been published in Bulletin No. 261, and full and complete descriptions are contained in the detailed report given in Professional Paper No. 48. Briefly, the results show great economy in the use of fuel for the production of power by this method. From the results so far obtained it seems probable that a gain in efficiency of 100 per cent may be expected over the ordinary practice with the steam engine. Although this gain applies to all grades of coal that were tested, the most striking results were obtained from the use of low-grade bituminous coals and lignites. The results were of such a character that they seemed to foretell a revolution in the mode of generating power in the near future, and if they are borne out in actual practice the low grade, dirty coals of Iowa and Missouri may be made to yield as valuable results as are at present obtained by the highest grade steam coals of West Virginia. This method also offers a great opportunity for the utilization of brown lignites of the northwest and of Texas, which, up to the present time, have been little used for such purposes.

Since the amount of ash has little effect in producer practice, unless clinkers are formed, it is probable that this method will afford a solution of the present great problem of the utilization of slack coals. This is one of the most serious questions that confront coal operators in this country, and the experiments so far conducted at St. Louis seem to show that waste products of this kind can be utilized to decided advantage in a producer plant. 


\title{
THE WARRIOR COAL BASIN IN THE BIRMINGHAM QUAD- RANGLE, ALABAMA.
}

\author{
By Charles Butts.
}

\section{INTRODUCTION.}

The present paper is a preliminary and provisional report on a comparatively welldeveloped and well-known area. It is based on work done in the past field season, continuing the geologic survey of the Birmingham district. The region has been described by Mr. Henry McCalley, assistant State geologist, in the reports of the Alabama Geological Survey entitled "On the Warrior Coal Field" (1886) and "Report on the Warrior Coal Basin," with map (1900). Much help has been derived from these reports. The writer also acknowledges the receipt of valuable information from many individuals and $\cdot$ mining companies operating in the region.

\section{LOCATION.}

The Birmingham quadrangle lies mainly to the north of Birmingham, Ala., and includes most of the city. It is a rectangular area of nearly 1,000 square miles, included within the parallels $33^{\circ} 30^{\prime}$ and $34^{\circ}$ and the meridians $86^{\circ} 30^{\prime}$ and $87^{\circ}$. The northern boundary runs just north of Bremen and Cleveland, the eastern is a short distance east of Chepultepec and Henryellen, the southern passes through the southern part of Birmingham, and the western lies just west of Littleton and Bremen. The part of the area containing the coal beds described below is shown in the sketch map (Pl. V). On this map the areas underlain by workable coal beds are inclosed by the line representing the outcrop of the Black Creek seam. There are two principal areas-one in the southwestern part, wedge-shaped, broadest to the southwest, and extending northeastward to beyond the center of the quadrangle, and one in the northwest corner in the region of Arkadelphia Mountain. These will be designated as the southern and northern fields of the quadrangle. A few small outliers of coal occur near Arkadelphia Mountain and a considerable area in the vicinity of Creel. The combined areas equal about 250 square miles.

\section{TOPOGRAPHY.}

The surface of the coal-bearing territory is rough. Altitudes vary from 300 feet along the forks of Black Warrior River to 800 feet in the highest hills. Between the large streams are generally flat ridges, from which run off long, narrow spurs, separated by deep ravines. The larger valleys are narrow and crooked along a large part of their length, and bordered by bluffs or cliffs in many places.

Locust Fork of Black Warrior River drains the southern coal field and Mulberry Fork the northern. The minor drainage of the southern field is northwestward; that of the northern is southeastward. In the southern field, Village, Fivemile, Crooked, Cunningham, Turkey, and Gurley creeks are the most important streams; in the northern field Dorsey Creek is the only large stream.

Notwithstanding the roughness of the country it has been possible without great expense to reach by railroad many points at which the several seams of coal can be mined to advantage. There seem to be no serious obstacles to reaching all other points also at which mines can be advantageously located. 


\section{GEOLOGY.}

\section{STRATIGRAPHY.}

The coal-bearing rocks are of Pottsville age, like those of the New River and Kanawha coal fields of West Virginia and the lower rocks of the anthracite fields of Pennsylvania. They are sandstone and shale, with occasional thin limestones. The sandstone horizons are persistent, and some particular beds can be traced over large areas. The coal scams are generally closely associated with sandstone. The total thickness of rocks from the highest beds in the center of the syncline to the bottom of the Black Creek conl seam, as compiled from measurements in different parts of the basin, is 1,216 feet. Below is a generalized section:

Generalized section of coal-bearing rocks above the floor of the Black Creek coal.

\begin{tabular}{|c|c|c|}
\hline & Thickness. & Depth. \\
\hline ITorizon of Gwin coal. & Feet. & Fect. \\
\hline Shale............... & 10 & · 10 \\
\hline Sandstone...................... & 30 & 40 \\
\hline Shale............................ & 100 & 140 \\
\hline Conl $(\mathrm{Cobb}) \ldots \ldots \ldots \ldots$ & 2 & 142 \\
\hline Shale.................... & 5 & 147 \\
\hline 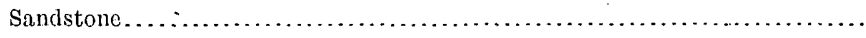 & 40 & 187 \\
\hline Shale and sandsțone................. & 260. & 447 \\
\hline Coal (Pratt) $\ldots \ldots \ldots \ldots \ldots \ldots \ldots \ldots \ldots$ & 3.5 & 450.5 \\
\hline Sandstone.................. & 35 & 485.5 \\
\hline Coal (Nickel Plate) ............ & 2.5 & 488 \\
\hline Sandstone.................. & 20 & 508 \\
\hline Shale..................... & 40 & 548 \\
\hline Coal (Curry) ............ & 1 & 549 \\
\hline Shale and sandstone.... & 30 & 579 \\
\hline Conl (Gillespie) $\ldots \ldots \ldots \ldots \ldots \ldots \ldots \ldots \ldots$ & .5 & 579.5 \\
\hline Shale and sandstone ................... & 313.5 & 893 \\
\hline Coal (Newcastle) ........................ & 2 & 895 \\
\hline Shale.................. & 28 & 923 \\
\hline Coal (Mary Lee) ........ & 6 & 929 \\
\hline Shale or sandstone $\ldots \ldots \ldots \ldots \ldots \ldots$. & 60 & 989 \\
\hline 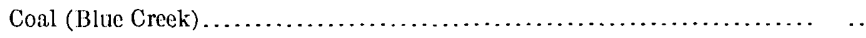 & 2 & 991 \\
\hline 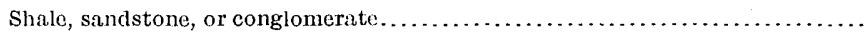 & 50 & 1,041 \\
\hline 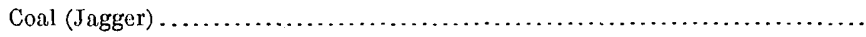 & 3 & 1,044 \\
\hline 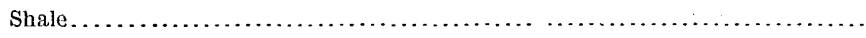 & 10 & $.1,054$ \\
\hline 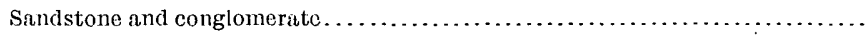 & 25 & 1,079 \\
\hline 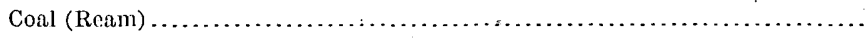 & 1 & 1,080 \\
\hline 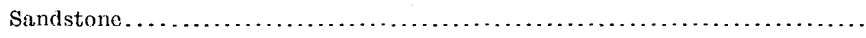 & 40 & 1,120 \\
\hline 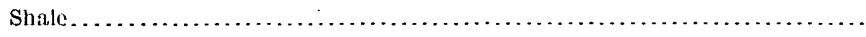 & 40 & 1,160 \\
\hline 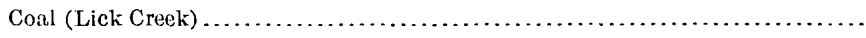 & 1 & 1,161 \\
\hline 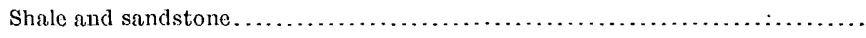 & 40 & 1,181 \\
\hline 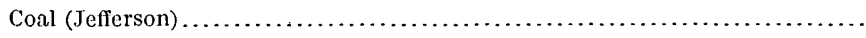 & 2.5 & $1,183.5$ \\
\hline 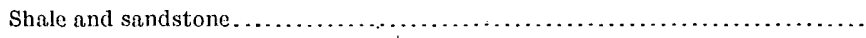 & 30 & $1,213.5$ \\
\hline Coal (Black Creek) ............................................ & 2.5 & 1,216 \\
\hline Shale and sandstone. & & \\
\hline
\end{tabular}

In this section the details of thickness and character of the rocks are only an approximate average, but the intervals between the principal coal beds are fairly correct. The distance between the Cobb and Pratt coal beds was determined west of Wylam and Ensley, where the elevation of the Cobb coal was determined from its outcrop, and the elevation of the 


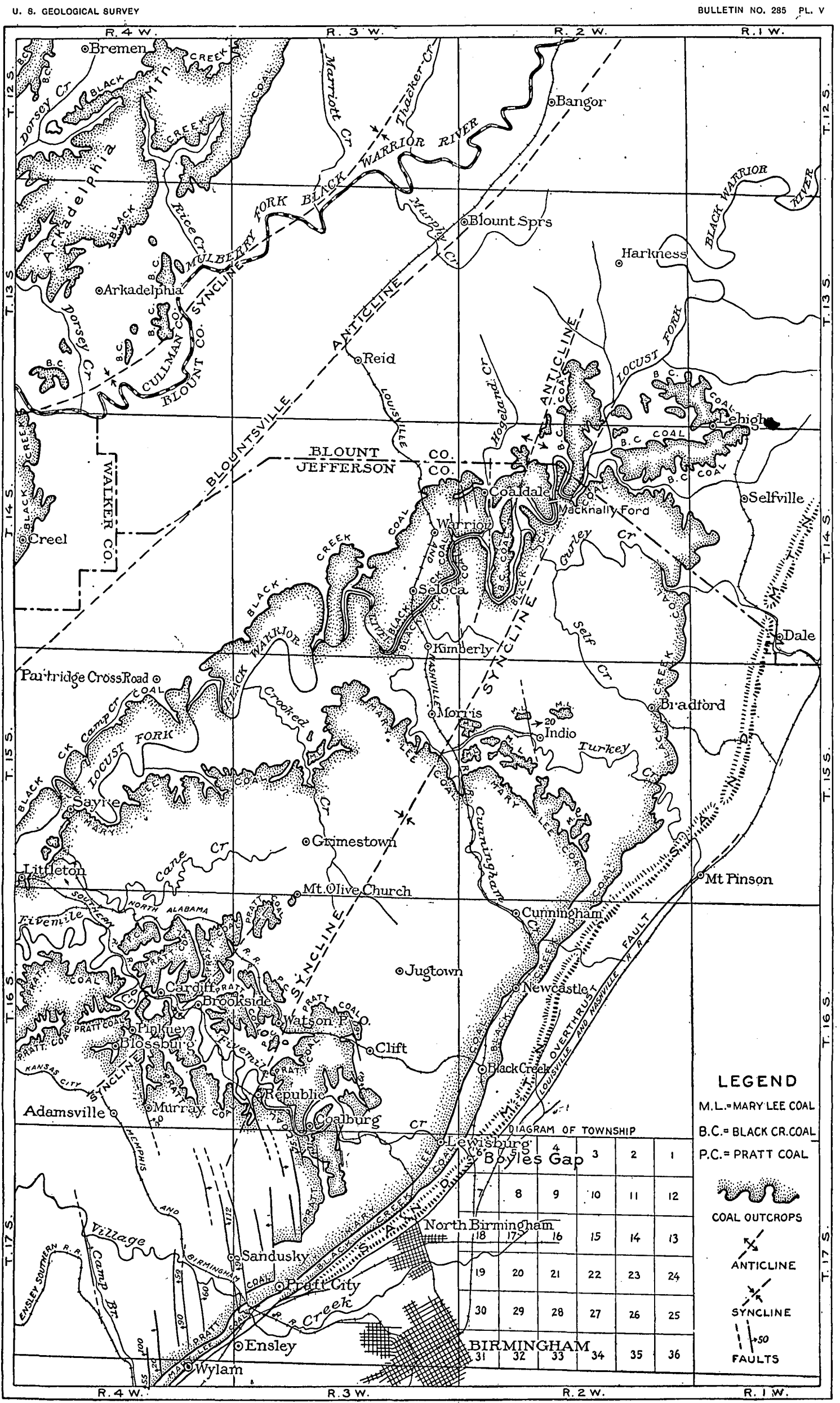

MAP OF THE WARRIOR COAL BASIN, IN THE BIRMINGHAM QUADRANGLE, ALABAMA. 
Pratt seam directly below is given in mine levels and bore holes. The average of two determinations of the interval by this means is 325 feet. The interval between the Pratt and Mary Lee seams, 473 feet, is obtained from the log of a bore hole in Sleepy Hollow near Blossburg. The interval between the Mary Lee and Jagger coals is compiled from observations made west of Morris, and is about right. The section between the Jagger and Black Creek coals was measured in a mine shaft at Kimberly

\section{STRUCTURE.}

To the southeast of the southern field a great thrust fault extends from Birmingham to Mount P. .nson. The fault approaches nearest the coal measures from Pratt City to Wylam. Northeastward it diverges more and more to Mount Pinson. The rocks bounding the fault on the northwest are vert:cal or overturned to the west, with a southeasterly dip. West of the vertical zone the northwesterly dip decreases, so that in a distance of from 1 to 2 miles the rocks dip only $10^{\circ}$ or $15^{\circ}$ to the northwest or are nearly flat. Along the western edge of the field the rocks dip at a small angle to the southeast. In the southern field, as a whole, the rocks d.p, in generkl, from the margin toward a line following Black Warrior River through Macknally Ford and extending southwestward to Republic, beyond which the rocks are so nearly horizontal and so much faulted that it would be difficult, with the data now at hand, to locate the ax.al line. The axis of the syncline pitches regularly to the southwest. The elevation of the Black Creek coal is about 500 feet above the sen on the axis near Dean Ford and about 450 feet below sea level south of Republic, making the total descent of the seam between the two points 950 feet. The basin is therefore spoonshaped. There is a low ant:cline running about midway between the main synclinal axis and Coaldale and Kimberly, and a low syncline near Brooks:de and Pinkney. The southern field is also much faulted, especially along the southeastern margin. These faults are abundant from Wylam to Clift, on the Northern Alabama Railway, or at least are much better known in that area, where they have been encountered in mining. There are faults also in the vicinity of Warrior and Coaldale. $\Lambda$ fault passes just west of Indio and another was encountered in mining the Black Creek seam just east of Newcastle. The position of these faults is shown on the sketch map (PI. V). The course of noarly all of the faults is N. $10^{\circ}$ to $20^{\circ} \mathrm{W}$. The displacement var.es from 10 to 112 feet. The fault planes are nearly vertical, generally making an angle of $70^{\circ}$ to $80^{\circ}$ with the horizon. The coal is reported undisturbed and workable r:ght up to the faults. Between Newcastle and Cunningham stat:on is a disturbed area, the rocks exposed in the ra:lroad cuts midway between the two places being greatly distorted. This disturbance is spoken of as a fault, but it appears to be an overturned anticline. The disturbed zone extends northeastward parallel to Sand Mounta:n and about 1. mile northwest thereof to Turkey Creek, though the disturbance is not so great at all points along this course as it is between Newcastle and Cunningham station.

The structure of the northern field is very simple. A synclinal axis p.tching to the southwest appears to pass through Arkadelphia and cross the western margin of the quadrangle near Locust Fork of Black Warrior River. The strata of Arkadelph:a Mountain dip southenstward and those of the area north of Creel dip northeastward to the axis. The dip is low in both areas, probably not exceeding 100 feet to the mile.

COALS.

\section{GENERAT, STATEMENT.}

The coal seams of the Warrior basin were divided by Henry McCalley $a$ into six groups, wh:ch, in descending order, are as follows: Brookwood, Gwin, Cobb, Pratt, Mary Lee, and Black Creek. Each group consists of two or more seams, separated by from 20 to 60 feet of shale or sandstone, or both, though sandstone generally predominates. The intervals between groups vary from 100 to 300 feet. The rock filling these intervals is usually shale. 
BROOKWOOD AND GWIN GROUPS.

The Brookwood and Gwin groups are so high in the series that they do not occur in the Birmingham quadrangle, though the sandstone ridge south of Camp Branch reaches up to the horizon of the Gwin seam. No traces of that seam were seen, and if it is present it occurs only in small areas under thin cover in the southwest corner of the quadrangle, and is of no commercial importance.

COBB GROUP.

The Cobb group of conls occurs only in the southwest corner of the quadrangle and is not economically important, so w.ll not be discussed here.

PRATT GROUP.

The Pratt group includes the Pratt, N.ckel Plate, Curry, and Gillesp:e seams. Only the Pratt and Nickel Plate are important. Generally the Curry and Gillespie seams are not minable.

Pratt seam.-This has been the most important mining seam in the quadrangle, but its area is less than that of any of the other prominent seams, as shown by its outcrop on the map (Pl. V). Its thickness, character, and quality are fairly constant. In an area lying, in a general way, south of Fivem:le Creek, and including Republic, Pinkney, and Blossburg, the seam has two or three partings. The following sections are the average of three measurements each of the seam in th.s area. Section No. 1 represents its condition in that part of the area in which there are three partings and section No. 2 where there are only two partings.

Average sections of Pratt seam in the Republic-Blossburg region.

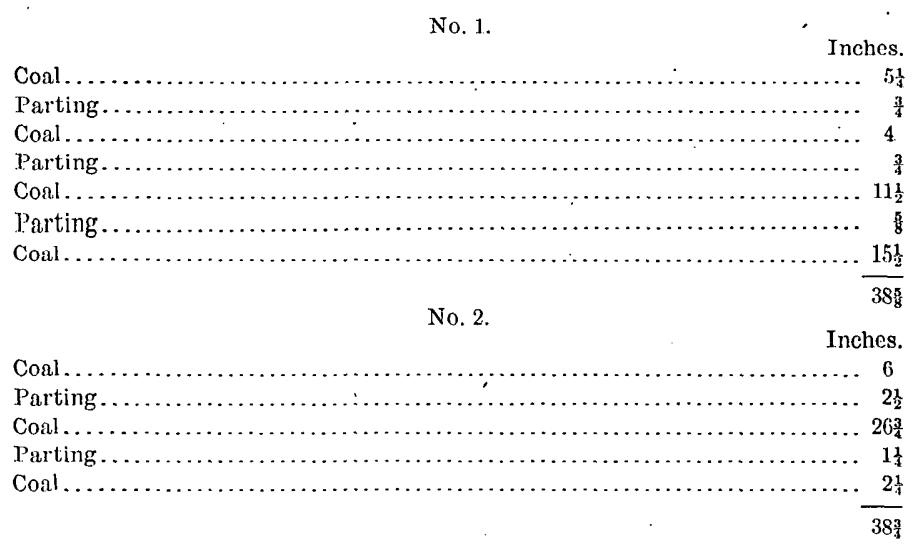

Outside of the area discribed above, on the northern and eastern margins of the field, the Pratt seam has almost universally one parting, as shown in the following section, which is the average of 26 measurements:

Average section of Pratt seam around northern and eastern margins of field.

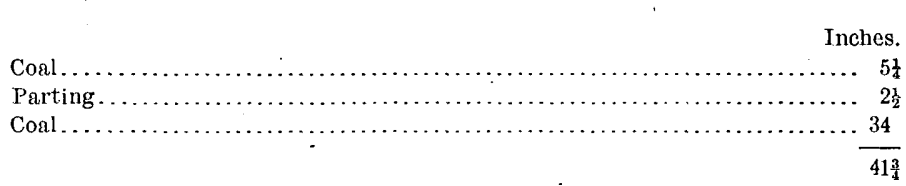

The above sect:ons ind cate a thinning as well as a deterioration in the character of the seam to the northwest. The Pratt seam has been more extensively mined than any other 
in this part of tne Warrior basin and is the standard coking and steam coal of the Birmingham district. Its chemical composition is shown by analyses Nos. 1 to 10 in the table on page $2 \dot{2} 1$.

Nickel Plate seam.-The Nickel Plate of this region is the same as the American seam of McCalley's report.a Nickel Plate is the name universally used by the miners of the region and for that reason is adopted here. It is known to be a workable seam in a large part of the territory between its northwestern outcrop and a line roughly drawn from Jugtown to Adamsville. The Nickel Plate is 35 to 40 feet below the Pratt seam. The interval between them is usually filled by sandstone, which in most of the region closely overlies the lower seam. So far as known, the Nickel Plate seam is greatly broken by partings, and probably it is of little value along its southeastern outcrop. The seam, where workable, is uniformly about 32 inches thick and is generally divided into two nearly equal benches by a 2 -inch parting in the middle, as shown by the following section:

Average of nine measurements of the Nickel Plate seam.

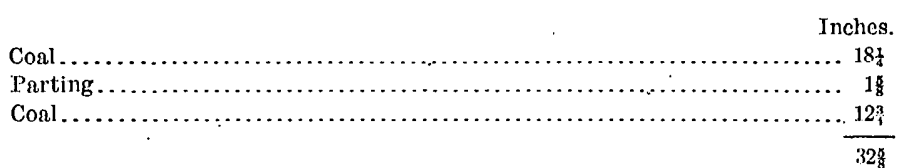

The upper bench is the purer conl, the lower bench carrying a larger proportion of ash and sulphur, as shown in analyses Nos. 11 to 14 , on page 221.

\section{MARY LEE GROUP.}

This group consists of the Newcastle, Mary Lee, Blue Creek, Jngger, and Ream seams. Wiih the probable exception of the Ream seam, these are all workable to a greater or less extent in the quadrangle.

Newcastle seam.-The Newcastle seam appears to be of minable dimensions only at Newcastle, where it exhibits the following average section:

Average of two measurements of Newcastle seam at Newcastle.

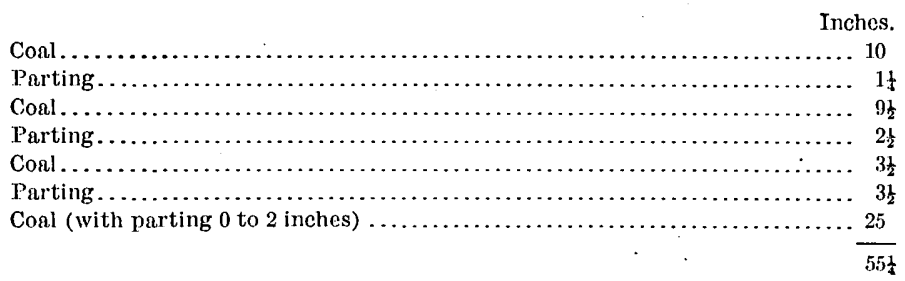

The seam as exhibited in this section is certainly known only over $\Omega$ small area wcst of Newcastle. A seam of similar character occurring at about the same horizon is known to the northeast and north of Newcastle as far as Morris. This may be either Newcastle or Mary Lee, or a seam formed by the union of both. It is regarded here as the Mary Lee, since there appears to be one seam of the group wanting in the region. Southwest of Morris the Newcastle seam is thin, so far as known, and from 5 to 40 feet above the Mary Lee seam.

Mary Lee seam.-The Mary Lee seam is of great importance, since on account of its extent, thickness, and composition it is destined to become the main source of supply of coking coal in the region when the Pratt seam is exhausted. It is best known at Littleton and Sayre, on its northwestern outcrop, and at Lewisburg and Sayreton, on its southeastern outcrop. The seam can be identified with certainty from Sayre to Crooked Creck. From the vicinity of Morris around the northeastern outcrop to Newcastle there is doubt 
whether the top seam of the Mary Lee group is Newcastle or Mary Lce. It is treated here as Mary Lee. The sam is not well known along its outcrop southwest of Sayreton.

The Mary Lee is a thick but very dirty seam. The coal requires washing before it is made into.coke. The following average sections from various points exhibit its general character: Average section of Mary Lee seam at Littleton and Sayre.

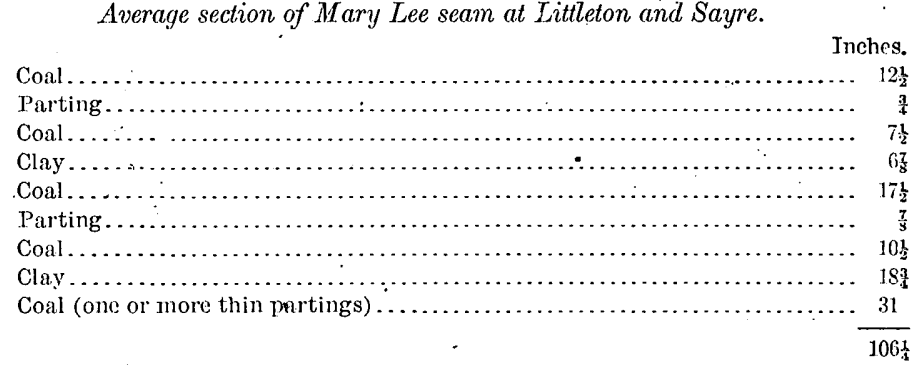

The two thick clay partings aro pcrsistent features of the seam in this locality. They divide the coal into three thick benches, which are more or less broken by thin sporadic partings.

West of Morris, in the vicinity of Crooked Creek, the tripartite character of the seam is not quite so conspicuous, although it still persists, as shown in the section below:

Average section of Mary Lee seam near Morris and Crooked Creek.

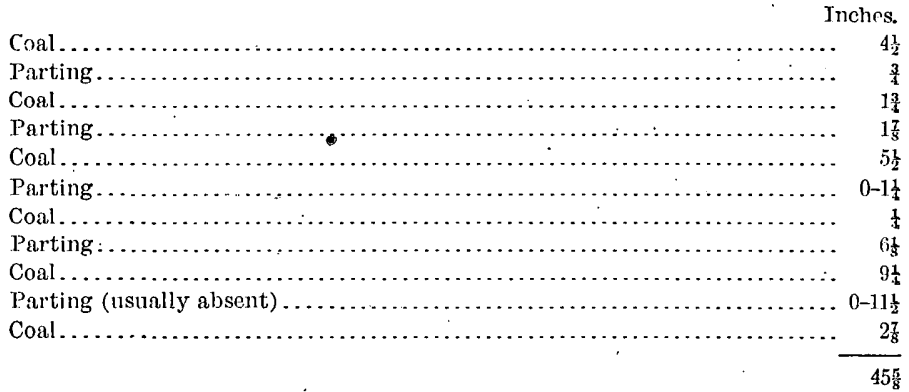

The partings of $1 \frac{7}{8}$ and $6 \frac{1}{3}$ inches shown in this section appeared in every section from which the average was obtained, and are constant features in the locality. They are probably the same as the two thick partings farther west. Northeast of Morris are a few outliers of this saam. To the east, at. Fedora, along Flat Creek, and thence southwestward, it shows at a number of points. The coal is very dirty and generally thinner than it is farther south. It is always overlain by shale and underlain by sandstone. It is probably of Iess value along this part of its outcrop than elsewhere in the quadrangle. At Lewisburg and Sayreton it is a thick but dirty seam, as shown in the following section:

Average section of Mary Lee coal seam at Lewisburg and Sayrefon.

Inches.

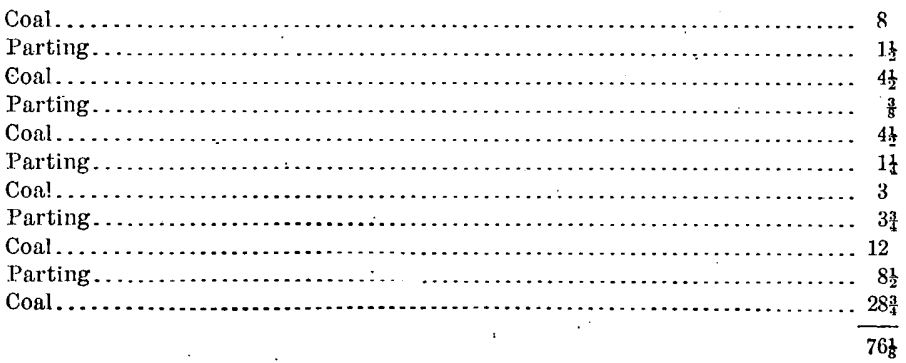


Farther southwest, in the SE. $\frac{1}{4}$ sec. 16 , T. 17 S., R. 31 W., the following section was measured at an old mine in what appears to be the Mary Lee seam:

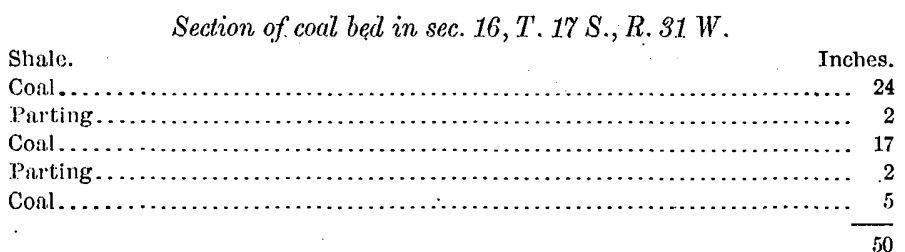

A seam outcropping in the road to Republic, about one-fourth mile north of its intersection with the Pratt City-Birmingham road, is probably Mary Lee. The only other point at which coal was seen that is possibly an outcrop of this seam is in Wylam, near the siding to Pratt No. 5 mine and about midway between the mine and the post-office. At this point a vertical outcrop shows the following section:

Section of coal bed in Wylam.

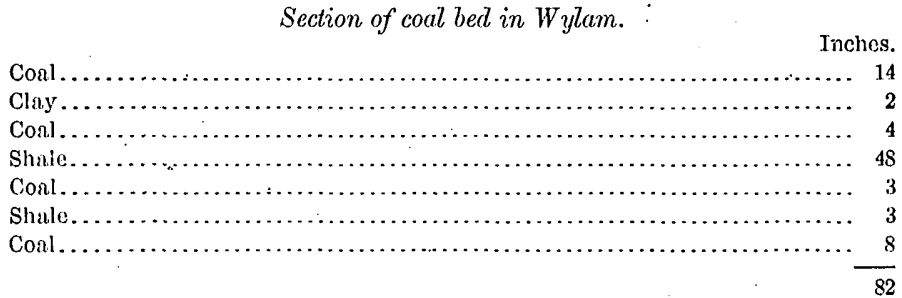

The position of this outcrop with regard to that of the Pratt seam, together with the dip of the strata, suggests that the coal is Mary Lee, though it may be some other seam of the Mary Lee group. On account of the weathering and crushing which the coal has undergone, the above section probably does not correctly represent its character in this locality.

Diamond-drill holes in the center of the basin show the Mary Lee coal to be of good thickness. It probably is a minable seam througbout. Analyses Nos. $1.5-20$ of the table on page 221 show the composition of the coal. It is coked and also used as a steam coal.

Blue Creek seam.-So far as known, the Blue Creek coal seam is of value only in the northenst end of the southern field, west, north, and east of Morris. The seam is of good thickness in this region, but, like the other seams of the Mary Lee group, it is very dirty, as shown by the following average of six sections measured at different points:

Average section of Blue Creek coal seam in the vicinity of Morris.

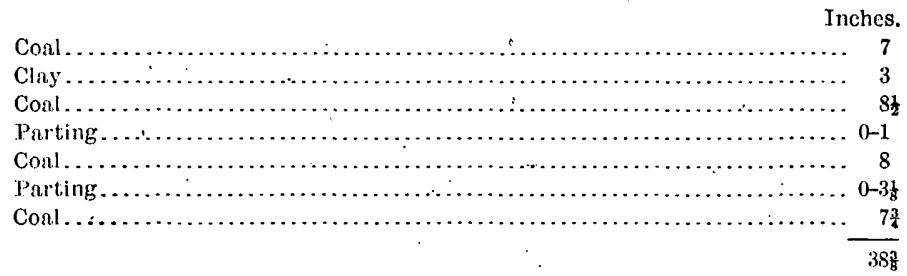

The partings are so distributed that generally there is no clean bench of coal over 14 inches thick. In only one section is there a clean bench 18 inches 1 hick. In sec. $27, T$. 1.5 S., R. 2 W., the Blue Creek seam reaches a great thickness, but is so full of partings as to be acarly worthless. Below is the section at this point: 
Section of Blue Creek coal seam in sec. 27, T. 15 S., R. $2 W$.

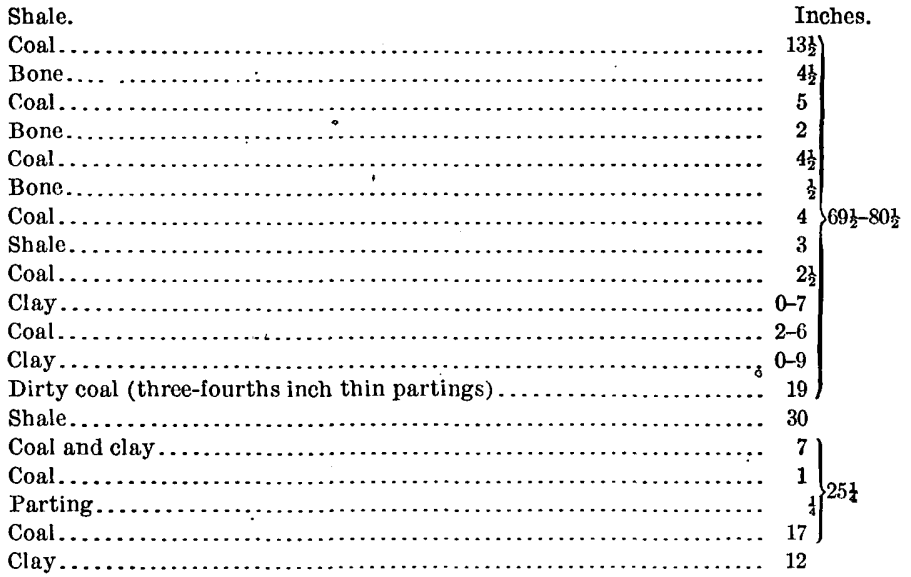

There is no evidence that the seam as developed at this point is of considerable extent in the locality.

The seam is probably not known southwestward of the point described above to beyond Newcastle, but on the Louisville and Nashville Railroad, about one-fourth mile north of the junction of the Northern Alabama Railway, a seam is exposed which is probably Blue Creek. Below is the section:

Section of Blue Creek coal seam on Louisville and Nashville Railroad, one-fourth mile north of junction of Northern Alabama Railway.

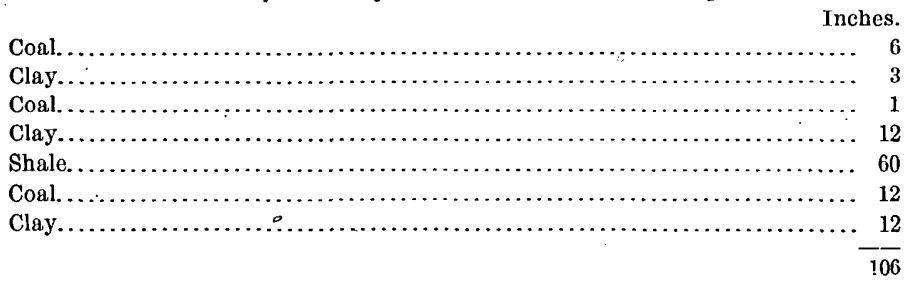

Farther south little or nothing is known of this seam and it is probably of no value along the outcrop.

Jagger seam.-The Jagger is a minable seam on Trouble Creek, along the river to the north of this creek, and perhaps along the river southwest of these localities. On Trouble Creek the top of the seam was seen in old pits and $2 \frac{1}{2}$ to $3 \frac{1}{2}$ feet of coal were reported by a man who had helped open the pits. On the south bluff of the river one-fourth mile west of the mouth of Whites Creek the following section was measured:

Section of Jagger coal seam one-fourth mile west of mouth of Whites Creek.

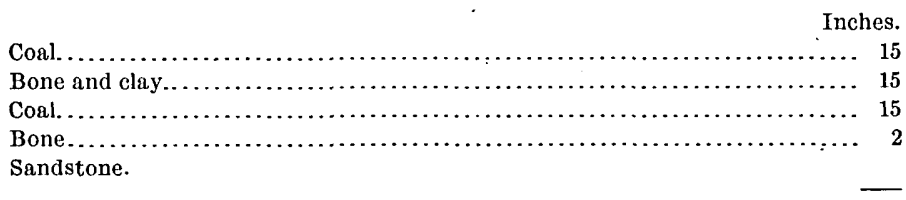

On the head of Whites Creek it is thin and lies under a coarse sandstone. Around the northeast end of the field it is thin or very dirty, as at Kimberly and Seloca, where it is exposed in railroad cuts. It is everywhere worthless in this region. 


\section{BLACK CREEK GROUP.}

This' is the lowest group of workable coals in the quadrangle and it has the greatest cxtent: The outcrop of the Black Creek seam on the map (Pl. V) shows the areas underlain by workable conl in the Warrior Basin. The Black Creek group comprises the Lick Creek, Jefferson, and Black Creek seams. Only the Jefferson and Black Creek are workable coals.

Jefferson seam.-The Jefferson seam is reported 29 inches thick about 1 mile west of Littleton. Along the northwestern outcrop, from Littleton to Cane Creek near Watt, the Jefferson seam is not well known and appears to be of little value. In the Watt-SelocaKimberly region it is a minable seam running over 30 inches thick with partings. An. average of seven sections in this region is given below:

Average section of Jefferson coal seam in Watt-Kimberly region.

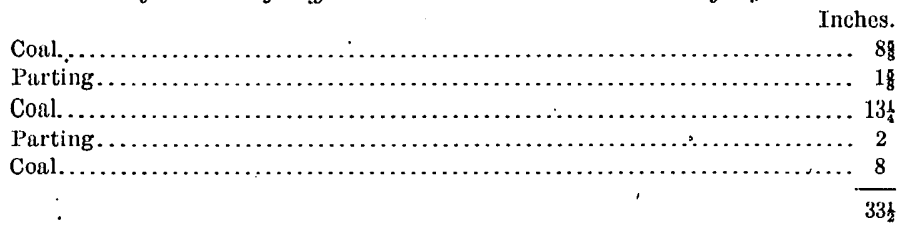

At Warrior the seam is split into two or three benches, separated by shale of varying thickness up to 20 feet. Along the outcrop north of Warrior the seam appears to have returned to normal conditions, as revealed in mining operations. Around the northeast end of the basin toward Lehigh and Self ville the Jefferson coal is thin and worthless. At Indio, however, it is of good thickness, but is broken into three benches by thick partings, as shown in the following section, which is the average of two measurements at the Indio shaft:

Average section of Jefferson coal seam at Indio.

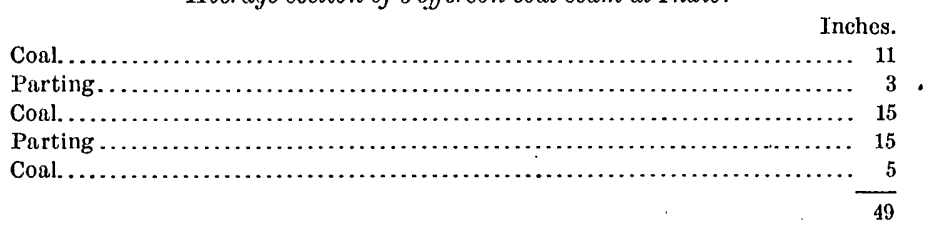

It is doubtful whether the Jefferson seam is of value anywhere along its southeastern outcrop from Lehigh to. Wylam.

In the Creel area south of Locust Fork McCalley $a$ gives measurements of this seam at three points, at two of which it is 30 inches thick and at the third 14 inches. It is not known in the Arkadelphia Mountain area.

As a whole this seam is variable in thickness and is workable only in certain regions, though its workable areas are of considerable extent.

Black Creek seam.-The Black Creek coal appears to be the most uniform in thickness and character of all the seams of the basin, except the Pratt. From Sayre to Warrior, including the mines at Kimberly, Watt, and Seloca, it runs about 2 feet of clear coal. Eight sections at points east of Warrior to Macknally Ford gave an average of $27 \frac{3}{8}$ inches of clear coal. At and south of Coaldale a parting occurs and the seam is slightly thicker. The following is an average of six sections in this locality:

Average section of Black Creek coal at Coaldale.

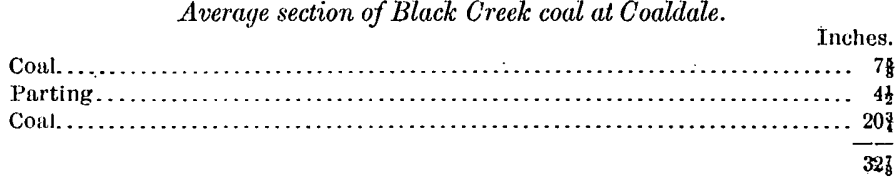


The average in the Lehigh district is 30 inches of clear conl and at Bradford and Indio 41 inches of clear coal. According to McCalley it will run from 24 to 20 inches as far south as Newcastle, where it is reported 31 inches thick at an old mine $\Lambda$ coal exposed in a railroad cut about one-half mile south of Hughes siding and identified by the writer as the Black creek senm has the following section:

Section of Black Creek coal one-half mile south of Hughes siding.

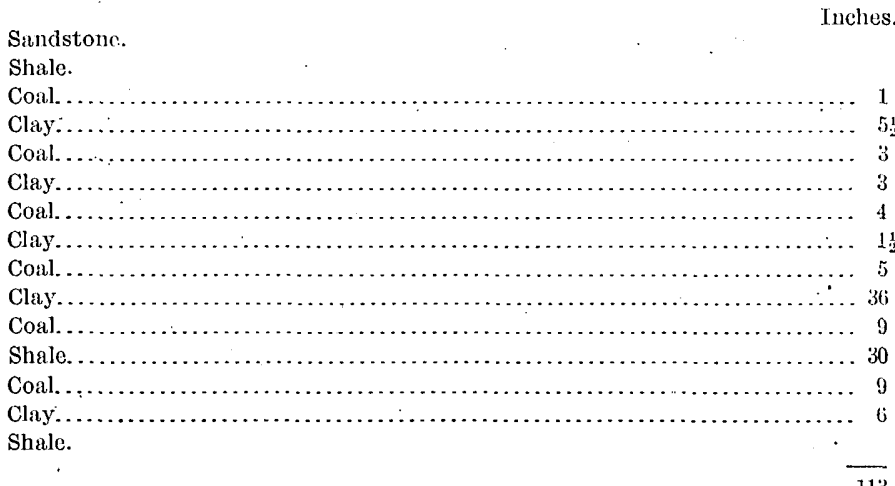

If this is the Black Creek seam it has undergone a great change between this point and the Newcastle mine. At an exposure $2 \frac{1}{2}$ miles farther southwest the scam shows a similar condition, though there is a clear bench of coal $26 \frac{1}{2}$ inches thick. From Sayreton to the southern edge of the quadrangle the seam is practically unknown.

In the Creel area the coal runs 30 inches thick, generally of clean coal. In the Arkadelphia Mountain area the seam averages 26 inches of clear coal. It is immediately or closely overlain throughout this area by a thick, coarse sandstone and over large parts of the area it is underlain by sandstone.

The Black Creek coal is one of the most highly esteemed of the Alabama coals for steam and domestic purposes. On account of its great extent, its generally uniform thickness and character, and its excellent quality it must be reckoned as a very valuable resource. It will furnish future supplies of coal after the thicker seams of the basin have been exhausted.

\section{MINING CONDITIONS}

Mining conditions are generally favorable. Except along the southeastern margin of the field from Bradford to Wylam the dip is low and even along this line only the lower coals dip more than $15^{\circ} \mathrm{NW}$. as far south as Lewisburg. From Lewisburg southward the dip increases rapidly and at Wylam the seams of the Mary Lee group are vertical on the outcrop and the Pratt dips $30^{\circ}-40^{\circ} \mathrm{NW}$. The coal of the basin can mostly be'mined out from the outcrop. The roof is generally firm. The coal separates readily from the roof and partings. The mines are but little affected by water and gas. The worst obstacles to mining so far encountered are the faults described on page 213. Many of these are now known and they can be taken into consideration in planning future operations in the lower seams, but undiscovered faults probably exist which will add an element of uncertainty to future calculations.

\section{DEVELOPMENTS.}

Operations in this part of the Warrior Basin have so far been confined to six seams, namely, the Pratt, Nickel Plate, Newcastle, Mary Lee, Jefferson, and Black Creek. The Pratt has been most largely mined and extensive tracts have been worked out. Of the other seams comparatively small areas only have been mined out.

At present there are 38 mines operating in the Pratt seam, 11 in the Nickel Plate, 1 in the Newcastle, 8 in the Mary Lee, 4 in the Jefferson, and 8 in the Black Creck. A few of these mines have been idle for a year or more on account of labor and other troubles. 


\section{CHARACTER AND COMPOSITION OF THE COAL.}

The coals of the region are all bituminous. They average about 58 per cent fixed carbon, 27 per cent volatile hydrocarbons, 10 per cent ash, 2 per cent moisture, and 2 per cent sulphur. They are good fuel and steam coals and make excellent coke. The coking property of these coals gives them exceptional value. The coal from the Mary Lee seam everywhere and from the Pratt seam in localities is so full of impurities-clay, shale, and slate-that it is unfit for coking as it comes from the mines. These impurities are derived from the many partings that occur in the seams, as can be seen by a study of the detailed sections given in the preceding pages of this report. It is therefore necessary in the worst cascs and desirable in others to remove these impurities by washing the slack and crushed coal in specially constructed washeries.

The composition of the Pratt, Nickel Plate, and Mary Lee seams is shown in the following table. These analyses were made under the supervision of Prof. N. W. Lord at the fuel-testing plant of the United States Geological Survey at St. Louis, Mo. The samples analyzed were taken in the following manner: From a freshly exposed face of conl a section was cut from top to bottom of the seam or bench sampled of sufficient width and depth to yield about 50 pounds of coal, rejecting, so far as possible, such impurities as are excluded from the coal in mining. By pulverizing and quartering down the sample was then reduced to convenient size and sealed up in a glass jar or galvanized-iron can. It was then soon sent to the coal-testing plant, where it was sealed in a glass jar until analyzed. In this way it is believed that samples were obtained that closely represent the quality of the coal that is put on the market.

Analyses of coal from Warrior field, Alabama.

\begin{tabular}{|c|c|c|c|c|c|c|c|c|c|c|}
\hline . & 1. & 2. & 3. & 4. & 5. & (i. & 7. & 8. & 9. & 10. \\
\hline Moisture.......... & 2.51 & 2.68 & 2.07 & 2.27 & 1.83 & 2.88 & 2.27 & 2.66 & 1.63 & 1.80 \\
\hline volatile matter... & 27.10 & 25.17 & 26.80 & 27.00 & 29.28 & 29.56 & $26.86^{\circ}$ & 29.93 & 30.81 & 28.52 \\
\hline Fixed carbon...... & 59.96 & 61.82 & 61.28 & 57.70 & 57.53 & 56.91 & 55.82 & 59.04 & 64.03 & 64.73 \\
\hline$\Lambda s h \ldots \ldots \ldots \ldots . . .$. & 10.43 & 10. 33 & 9.85 & 13.03 & 11.36 & 10.65 & 15.05 & 8.37 & 3.53 & 4. 89 \\
\hline Sulphur........... & 1.68 & 1.86 & 2.13 & 1.79 & 4. 24 & 2.04 & 2.45 & 1.71 & .57 & 2. 27 \\
\hline $\begin{array}{l}\text { Calorific value de- } \\
\text { termined: }\end{array}$ & & & & & & & & & & \\
\hline - Calories....... & 7,571 & & & & & 7,477 & & & & \\
\hline $\begin{array}{c}\text { British ther- } \\
\text { mal units.... }\end{array}$ & 13,628 & & & & & 13,459 & & & & \\
\hline $\begin{array}{l}\text { Air - drying loss, } \\
\text { per cent.............. }\end{array}$ & 1. 60 & 1.80 & 1.40 & 1.40 & .90 & 1. 60 & 1. 10 & 1.60 & & \\
\hline & 11. & 12. & 13. & 14. & 15. & 16. & 17. & 18. & 19. & 20. ' \\
\hline Moisture..... & 3.35 & 3.10 & 2.86 & 1.76 & 3.14 & 3. 40 & 2. 89 & 3.35 & 2. 49 & 2. 16 \\
\hline Volatile matter... & 26. 41 & 25.31 & 29.08 & 28. 52 & 28.46 & 26.68 & 28.87 & 26.92 & 27.34 & 27.11 \\
\hline Fixed carbon...... & 57.58 & 56.15 & 65.29 & 54.08 & 59.35 & 59.53 & 59.94 & 59.01 & 57.14 & 55.47 \\
\hline Ash.............. & 12.66 & 15.44 & 2.77 & 15. 64 & 9.05 & 10. 39 & 8.30 & 10.72 & 13.03 & 15.26 \\
\hline Sulphur............ & 1.84 & 3.11 & .95 & 4.05 & 1.05 & .65 & .63 & .67 & 1.37 & .93 \\
\hline $\begin{array}{l}\text { Calorific value de- } \\
\text { termined: }\end{array}$ & & & & & & & & & & \\
\hline Calories........ & 7,247 & & & & & & & 7,369 & & \\
\hline $\begin{array}{c}\text { British ther- } \\
\text { mal units.... }\end{array}$ & 13,045 & & & & & & & 13,264 & & \\
\hline $\begin{array}{r}\text { Air - drying loss, } \\
\text { per cent............... }\end{array}$ & 2.10 & 1.90 & 1.30 & 1.00 & 1. (i) & 2.00 & 1.60 & 2.20 & 1.20 & 1.30 \\
\hline
\end{tabular}


1. Pratt seam, Warner drift, Republic, Ala. Republic Iron and Steel Company, owner. E. E. Somermeier, analyst. Chas. Butts, collector.

2. Pratt seam, Warner drift, twelfth left heading, room No. 19, Republic, Ala. Republic Iron and Steel Company, owner. E. E. Somermeier, analyst. Chas. Butts, collector.

3. Pratt seam, Tutweiler No. 4 drift, seventh left heading, 900 feet from main entry, Pinkney, Ala. Tutweiler Coal and Coke Company, owner. E. E. Somermeier, analyst. T. M. Campbell, collector.

4. Pratt seam, Tutweiler No. 4 drift, ninth right heading, 600 feet from main entry, Pinkney, Ala. Tutweilér Coal and Coke Company, owner. E. E. Somermeier, analyst. T. M. Campbell, collector.

5. Pratt seam, No. 16 Pratt mine, scction 3, face heading mouth of fourth left entry, 1 mile west of Cardiff, Ala. Pratt Consolidated Coal and Coke Company, owner. E. E. Somermeier, analyst. E. M. Dawson, jr., collector.

6. Pratt seam, No. 16 Pratt mine, section 5, right heading entry No. 3, 1 mile west of Cardiff, Ale. Pratt Consolidated Coal and Coke Company, owner. E. E. Somermeier, analyst. E. M. Dawson, jr., collector.

7. Pratt seam, Kosmo mine, room No. 3, Mineral Springs, Ala. Pratt Consolidated Coal and Coke Company, owner. E. E. Somermeier, analyst. E. M. Dawson, jr., collector.

8. Pratt seam, Clift mine, Clift station, Ala. Pratt Consolidated Coal and Coke Company, owner. E. E. Somermeier, analyst. Chas. Butts, collector.

9. Pratt seam, No. 4 mine, six th cross heading, room No. 1, Wylam, Ala. Tennessee Coal, Iron, and Railroad Company, owner. F. M..Stanton, analyst. E. M. Dawson, jr., collector.

10. Pratt seam, No. 4 mine, room No. 5, Kelso entry, Wylam, Ala. 'Tennessee Coal, Iron, and Railroad Company, owner. F. M. Stanton, analyst. - E. M. Dawson, jr., collector.

11. Nickel Plate seam, Tutweiler No. 3 drif, fourth right heading, Pinkney, Ala. Tutweiler Coal and Coke Company, owners. E. E. Somermeier, analyst. T. M. Campbell, collector.

12. Nickel Plate seam. Tutweiler No. 3 drift, second left heading, Pinkney, Ala. Tutweiler Coal and Coke Company, owner. E. E. Somermeier, analyst. T. M. Campbell, collector.

13. Nickel Plate seam, No. 16 Pratt drift, upper bench, ff th right beading, 1 mile west of Cardiff, Ale。 Pratt Consolidated Coal and Coke Company, owner. E. E. Somermeier, analyst. E. M. Dawson, jr., collector.

14. Nickel Plate seam, No. 16 Pratt drift, lower bench, fifth right heading, 1 mile west of Cardiff, Ala. Pratt Consolidated Coal and Coke Company, owner. E. E. Somermeier, analyst. E. M. Dawson, jr., collector.

15. Mary Lee seam, Thomas slope, ninth left cross heading, top bench, Littleton, Ala. Little Warrior Coal and Coke Company, owner. E. E. Somermeier, analyst. T. M. Campbell, collector.

16. Mary Lee seam, Thomas slope, ninth left cross heading, middle bench, Littleton, Ala. Little Warrior Coal and Coke Company, owner. E. E. Somermeier, analyst. T. M. Campbell, collector.

17. Mary Lee seam, Thomas slope, ninth left cross heading, bottom bench, Littleton, Ala. Little Warrior Coal and Coke Company, owner. E. E. Somermeier, analyst. T. M. Campbell, collector.

18. Mary Lee seam, Thomas slope, tenth left cross heading, whole seam, Littleton, Ala. Little Warrior Coal and Coke Company, owner. E. E. Somermeier, analyst. T. M. Campbell, collector.

19. Mary Lee scam, Lewisburg slope, bottom of main slope in manway, 60 feet from main slope, top bench, Lewisburg, Ala. Alabama Consolidated Coal and Iron Company, owner. F. M. Stanton, analyst. E. M. Dawson, jr., collector.

20. Mary Jee seam, Lewisburg slope, bottom of main slope in manway, 60 feet from main slope, bottom bench, Lewisburg, Ala. Alabama Consolidated Coal and Iron Company, owner. F. M. Stanton, analyst. E. M. Dawson, jr., collector. 


\title{
COAL IN THE MOUNT DIABLO RANGE, MONTEREY COUNTY, CAL.
}

\author{
By Ratph Arnold.
}

Location and topography.-A deposit of coal $a$ of commercial importance and also worthy of note because of its occurrence in such a comparatively recent formation as the Lower Miocene is found in Stone Canyon, near the middle of the Mount Diablo Range, Monterey County, Cal. The range in this region consists of a main divide, attaining an elevation of over 3,000 feet, and several less prominent parallel ridges, all trending in a general southeastnorthwest direction. The coal outcrops about midway down the western flank of the main ridge. The locality is about 23 miles northeast of Bradley, and may be reached over wagon road from either Bradley, San Miguel, or Coalinga.

Geology and structure.-The formations involved in the geology of the range in the immediate vicinity of the coal deposit are the serpentine, chert, and other metamoiphosed rocks of the Franciscan (pre-Cretaceous) complex, the Lower Miocene sandstone, and the basal sandstone and white shale of the Santa Margarita (Upper Miocene) formation. The Franciscan forms the core of the main ridge, outcropping intermittently along its top and also in a band along its western flank. The Lower Miocene sandstone, at the base of which is the conl bed, overlies the Franciscan unconformably and forms a steeply northeastwarddipping belt along the eastern side of the western band of Franciscan. A thickness of at least 500 feet of the Lower Miocene sandstone is exposed in the vicinity of Stone Canyon. About 35 feet above the top of the coal bed is a thin fossiliferous stratum in the sandstone, yielding the fauna which determines the age of the formation. The Santa Margarita beds, consisting of from 100 to 200 feet of conrse sandstone overlain by $1,000+$ feet of thinly laminated hard white shale, rest unconformably upon the Lower Miocene and cover considerable portions of the main ridge. In the immediate vicinity of Stone Canyon the Santa Margarita forms a southeast-northwest syncline, which separates the Franciscan area on the top and northeastern flank of the main divide from the Franciscan and coal-bearing Lower Miocene outcrops on the southwestern flank.

The local structure, as shown by fig. 9, is essentially that of a syncline of the Santa Margarita sandstone and shale resting on a post-Monterey (Middle Miocene) erosion surface. The Lower Miocene formation, including the coal at its base, is separated from the Franciscan complex by an unconformity, and possibly also by a zone of faulting.

Coal bed.-As previously stated, the productive coal bed occurs at the base of and conformable with the lower Miocene sandstone. The bed averages between 14 and 16 feet in thickness, and, in the places where it has been exploited, has a dip of about $70^{\circ} \mathrm{N} .40^{\circ} \mathrm{E}$. At some places along the outcrop where apparently the creep of the rocks down the side hill has affected it, the dip is as low as $30^{\circ}$ and the coal bed is pinched out to an exposure less

a A brief description, of this deposit and of the Stone Canyon coal mine is given in the Eighth Ann. Rept. Cal. State Mineralogist, 1888, pp. 403-404.

Bull. 285-06-15 
than 4 feet in thickness. The bed is said to extend for at least $2 \frac{1}{4}$ miles along the strike, the exploited area, however, being only some 3,000 or 4,000 feet long. The roof is of sandstone,

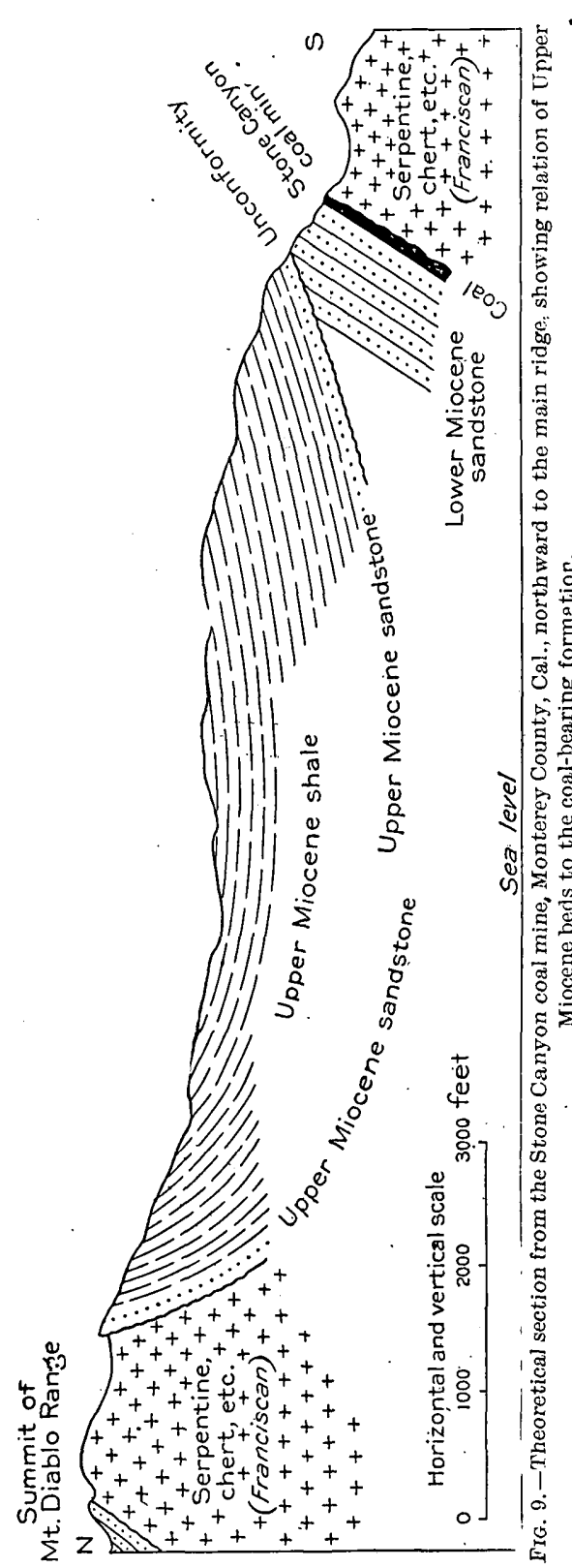

while the floor is clay, made up of decomposed serpentine and other Franciscan rocks. Whether or not this clay represents the residuum from pre-Miocene surface decomposition or is finely ground material along a fault zone, the writer is not prepared to state:

Properties of the coal.a-The coal is hard and exhibits a clean black fracture. Although called a lignite, it appears to approach bituminous. It carries no iron pyrites, the large quantity of contained sulphur occurring principally, so it is said, in the form of calcium sulphate. The coal does not take fire spontaneously and is noncoking. Heating tests show its calorific power to be 13,000 British thermal units. The following analyses, taken from a mining engineer's report on the mine, are said to represent fair averages from different parts of the mine:

Analyses of coal from Stone Canyon mine.

\begin{tabular}{r|r|r|r|r|r}
\hline $\begin{array}{c}\text { Sample } \\
\text { from- }\end{array}$ & Water. & $\begin{array}{c}\text { Volatile } \\
\text { carbon. }\end{array}$ & $\begin{array}{c}\text { Fixed } \\
\text { carbon. }\end{array}$ & Ash. & $\begin{array}{c}\text { Sull- } \\
\text { phur. }\end{array}$ \\
\hline & $P . c t$. & $P . c t$. & $P . c t$. & $P . c t$. & $P . c t$. \\
Tunnel & 6.13 & 50.08 & 36.39 & 7.40 & 4.65 \\
Do. & 6.14 & 48.57 & 38.84 & 6.51 & 4.82 \\
Do. & 5.50 & 50.34 & 37.61 & 6.55 & 5.09 \\
Do. & 7.12 & 49.15 & 34.88 & 8.93 & 4.74 \\
Shaft.. & 4.80 & 51.40 & 34.21 & 10.59 & 6.41 \\
Do. & 4.42 & 46.30 & 30.54 & 18.71 & 5.79 \\
Do. & 3.82 & 53.28 & 38.35 & 4.55 & 4.88 \\
Do. & 2.99 & 53.38 & 38.28 & 5.38 & 5.40 \\
& & & & & \\
\hline
\end{tabular}

Conclusions.-The coal appears to have been formed in a basin previous to the principal Miocene subsidence. The limits of this basin are unknown, although a deposit of coal found near La Panza, nearly 50 miles southeast, and occupying a similar stratigraphic position to that of the Stone Canyon bed offers evidence of rather widespread coal-forming conditions at the beginning of the Miocene.

Considerable prospecting has been carried on along the top of the range at the contact between the Santa Margarita sandstone and the Franciscan rocks, in an apparently analogous position stratigraphically to that in which the coal occurs on the west side of the syncline,

$a$ The writer is indebted to Mr. M. J. Horswell, assistant superintendent of the Stone Canyon coal mine, for a large part of the following information concerning the physical and chemical properties of the coal. 
a position in which, were the analogy true, coal would most likely be found. Paleontologic and structural evidence, gathered during a brief reconnaissance of this territory, appears, however, to indicate that this analogy is not true and that, in reality, the sandstones resting on the Franciscan along the top of the range lie stratigraphically unconformably above the coal-bearing sandstones, and are, therefore, not likely to contain coal. Fig. 9, illustrating the probable structural relations in the area under discussion, will indicate better than words the reasons for this last statement. 


\title{
THE YAMPA COAL FIELD, ROUTT COUNTY, COLO. ${ }^{a}$
}

\author{
By N. M. Fenneman and Hoy't S. Gale.
}

LOCATION.

The existence of important coal resources in northwestern Colorado has been known for many years. The region of greatest interest is in the eastern half of Routt County, lying in the upper valley of Yampa River. The area covered by this survey of the field is approximately 1,200 square miles and this is practically the extent of the Yampa coal field. It lies at the western foot of the Park Range of the Rocky Mountains. On the north are the high peaks and ridges of the Elkhead Mountains. On the south the field is interrupted by an east-west anticlinal fold through Axial Basin, supposed to the be eastward extension o: the Uinta uplift, which merges into the White River Plateau. To the west and northwest the coal-bearing rocks extend to an undetermined distance, disappearing beneath formations of later age.

The coal field lies approximately midway between the Union Pacific Railroad on the north and the Denver and Rio Grande Railroad on the south. Steamboat Springs, the most prominent town of the district, is usually reached by stage from Wolcott, Colo. The field is also reached by stage from Middle Park and Rifle, Colo., and from Rawlins, Wyo. A number of regular stage lines run through the field.

The prospect of a railroad through the center of the area has in recent years stimulated exploration and careful study. It seems almost certain that with more adequate transportation facilities the Yampa coal field will become an important factor in the supply of the western market. 'The coals are for the most part a good grade of bituminous, and anthracite of good quality is known to exist within a certain limited area.

- The field centers about a broad area of rolling country, of characteristically smooth slopes, although at places showing considerable relief. This is bounded by a sharply dissected rim of sandstone ridges rising to 1,200 or 1,500 feet above the drainage level. Yampa River cuts across the field in a westerly course, flowing through broad, open bottom lands where the course lies over the soft rocks of the prairie land and through canyons where it has cut across the sandstone ridges.

\section{STRUCTURE.}

This coal field as a whole is a well-defined structural unit. It is the extreme southeastern point of a huge synclinal basin of the coal-bearing rocks, the axis of which passes al :ac: directly through the towns of Yampa and Hayden. Since the basin as a whole plunges 10 the northwest, the beds along the axis dip in that direction. Following this axis from the extreme point of the fold, one passes over successively higher and higher members of the coal-bearing series until in Twentymile Park the uppermost group of coal beds is entered: These in turn are overlain by dark clay shale distinct in character from the rocks of the coalbearing formation.

The major syncline just described is interrupted by a number of cross folds or wrinkles. The most prominent of these minor folds is an anticline the axis of which follows the crests of the high ridges on the west side of 'Twentymile Park and crosses Yampa River at the mouth of Tow Canyon. On the north side of the river the axis bends a little west of north,

a This paper is a preliminary report, to be followed later by one giving fuller detals and a more complete map. 

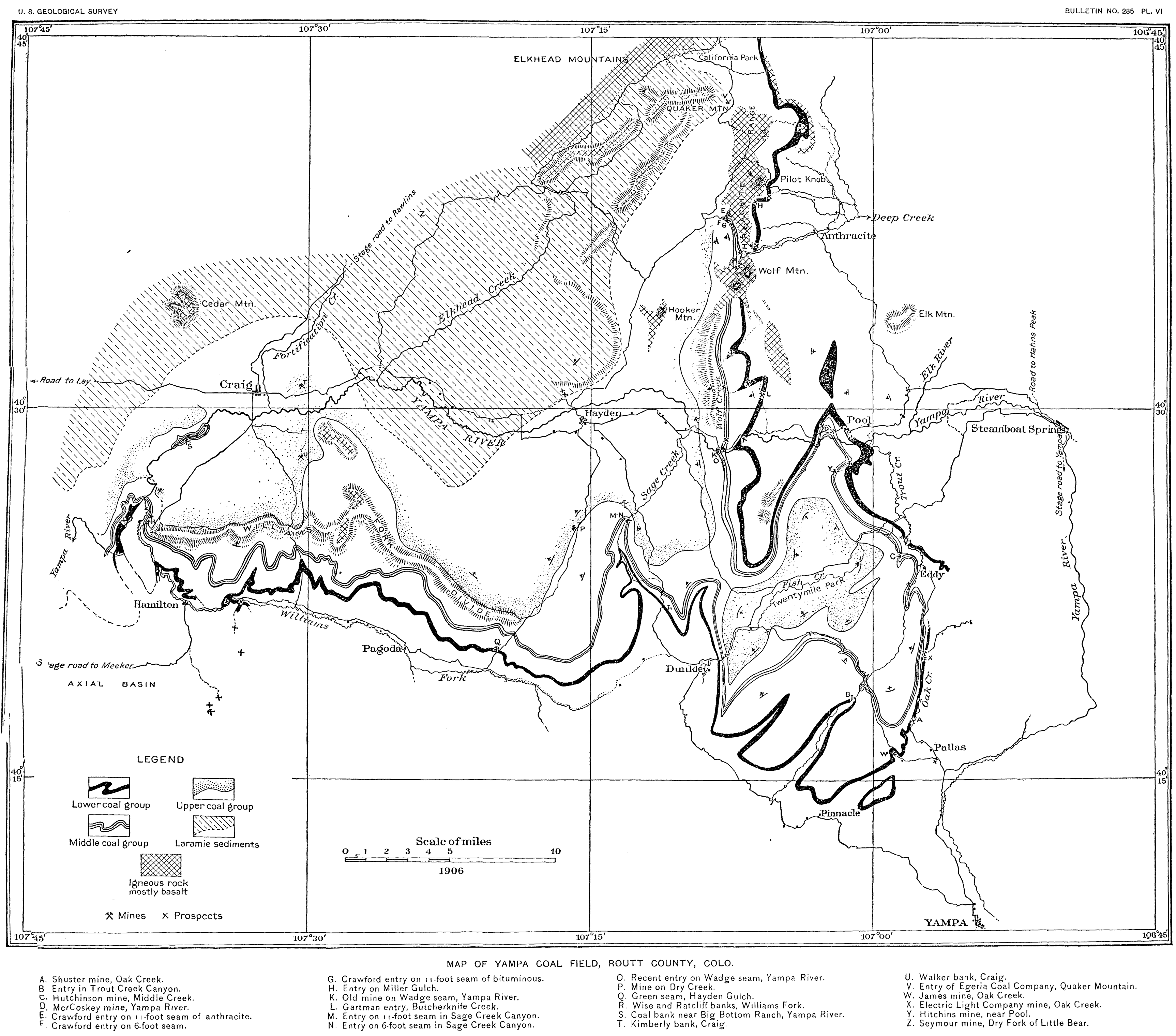

MAP OF YAMPA COAL FIELD, ROUTT COUNTY, COLO.

A.
C. Hutchinson mine, Middle Creek.
D. Mrchoskey mine, Yampa River.
E. Crawford entry on 11.foot seam of anthracite.
F. Crawford entry on 6.foot seam.

G. Crawford entry on 11-foot seam of bituminous.
H. Entry on Miller Gulch.
K. Old mine on Wadge seam, Yampa River.
L. Gartman entry, Butcherknife Creek.
M. Entry on 1 . foot seam in Sage Crek Canyon.
N. Entry on 6 foot seam in Sage Creek Canyon.

O. Recent entry on Wadge seam, Yampa River.
P. Mine on Dry Creek.
Q. Green seam, Hayden Gulch.
R. Wise and Ratcliff banks. Williams Fork.
S. Coal bank near Big Bottom Ranch, Yampa River.
T. Kimberly bank, Craig

U. Walker bank, Craig.
V. Entry of Egeria Coal Company, Quaker Mountain.

W. James mine, Oak Creek.
$X$. Electric Light Company mine, Oak Creek.

Z. Seymour mine, Dry Fork of Little Bear. 
disappearing into an area of igneous eruptives in the direction of Wolf Mountain. This cross buckle of the strata lies approximately at right angles to the major axis and cuts ofl a structural basin on the southeast or Yampa end of the field. The center of this subordinate basin is marked by the open prairie land of Twentymile Park.

The rest of the field is a broadly opened syncline whose outer rim is made up of ridges formed by the massive sandstones of the coal-bearing series. Within this rim, which is a marked topographic feature, is a belt of open prairie and valley land eroded on the soft black shale that overlies the coal beds. These in turn are replaced in the center of the syncline north and west of the town of Hayden by beds of the overlying Laramie formation. The latter dip away to the northwest until they are covered by the overlying Tertiary rocks, which are supposed to cover all of the region along the Colorado and Wyoming line.

West of Twentymile Park the sandstone ridges swing to the west and form a low range of mountains on the north side of Williams Fork, called the Williams Fork Mountains. The sharply dissected southern slope of these mountains exposes the upturned edges of the whole coal series for over 20 miles. The coal beds dip to the north, passing under the barren shale which forms the valley of Yampa River.

The rim of sandstone ridges bounds the east side of Hayden Valley from near Twentymilo Park to Wolf Mountain and Pilot Knob of the Anthracite Range. North of Pilot Knob the sandstones are much broken by intrusions of sheets and dikes of basaltic lava and consequently the rim of the basin is not well marked, but the coal beds have been traced in this direction as far as the flanks of Sand Mountain. All along this eastern rim of the field the rocks have a general westerly dip, also passing under the barren shale of the valley of Yampa River. In all probability the coals of the eastern rim extend beneath Hayden Valley and are continuous with the conl beds showing in the Williams Fork Mountains.

\section{STRATIGRAPHY.}

On the eastern side of the great syncline strata as old as Triassic lie tilted against the Archean core of the Park Range. To the west the.Dakota, Benton, and Niobrara are crossed, each in its turn dipping under the next higher formation. Above these, at a distance of several miles from the Archean core, is a thick mass of coal-bearing strata. Thcse rocks have been previously considered as of Laramie age, but fossils collected from them during the past scason's work were sufficient to determine definitely that they belong to the Montana group of the Cretaceous. This group is the equivalent of the Pierre and Fox Hills formations of other fields, although this subdivision can not well be applied here.

Stratigraphic sections in different parts of the field do not agree in their minor details, but a few of the dominant members of the series are very persistent throughout the area and serve as useful horizon markers. The chief of these are some of the massive sandstone beds and the three groups of coal seams. The following is a generalized section, compiled from inany such sections measured in various parts of the region:

Laramie:

\section{Generalized section of the coal-bearing series.}

Alternating soft sandstone and shale, with frequent lignite seams.............

Feet.

$900+$ Montana:

(1) Dark-colored clay shale, with calcareous seams, estimated as............ 1,000-2,000

(2) Coal-bearing rocks, consisting of-

(a) Alternating sandstone (at places massive) and shale containing the upper

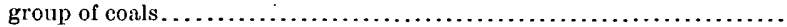

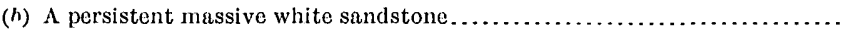

(c) Alternating sandstone and shale beds containing in their lower half the mid-

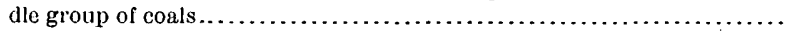

(d) A persistent massive white sandstone $\ldots \ldots \ldots \ldots \ldots \ldots \ldots \ldots \ldots \ldots \ldots \ldots \ldots \ldots \ldots \ldots \ldots \ldots$
(e) Alternating sandstone and shale beds containing near their middle the lower

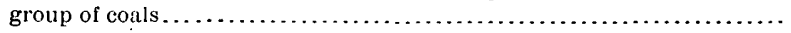

(f) Alternating sandstone and shale beds, massive sandstone predominating,

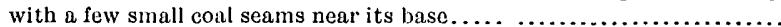

400

$50-\quad 150$

1,000

50- 150

800

800

(3) Dark-colored clay shale $\ldots \ldots \ldots \ldots \ldots \ldots \ldots \ldots \ldots \ldots \ldots \ldots \ldots \ldots \ldots \ldots \ldots \ldots \ldots \ldots \ldots \ldots 1,000-1,500$ 
Each group of coal seams ranges through a wertical distance of from 200 to 400 feet and the several groups are separated by from 500 to 1,000 feet of barren shale and sandstone. The number and thickness of coal beds constituting ench group vary from place to place. Usually there are in each group at least three seams of workable thickness and a number of smaller seams. Single beds of coal occur up to a thickness of about 20 feet.

At or near the base of each coal group are found conspicuous sandstone beds. These are characteristically massive and white and frequently more than 100 feet thick. While generally ridge or ledge makers, the exposed surfaces readily weather to a friable condition. The broad exposures are frequently marked by cracks making polygonal figures a foot or more in diameter. Great concretions and stains of iıon oxide are also common.

Below the three coal groups is a great series of very massive sandstone beds, sometimcs designated as the "barren sandstones." Where exposed these are usually prominent as a series of hogbacks. . As stated in the generalized section, a few small seams of coal are found low down in this series.

The Laramie, overlying the Montana, is composed of alternating sandstones and clay shales: At least 900 feet of such sediments are embraced in the steep scarp on the north bank of Yampa River at Hayden. In this bluff indications of lignite were found at twenty horizons, distributed somewhat regularly throughout the upper two-thirds of this thickness.

\section{COAL.}

For convenience in describing the various mines and outcrops the field has been divided into four main structural districts, as follows: (1) Twentymile basin, including the extreme southeast point of the syncline and bounded on the northwest by the cross anticlinal fold mentioned on a previous page; (2) Williams Fork Mountains, including the southern rim of the main basin west of the cross anticline and Twentymile Park, and the outcrops in Yampa Valley in the vicinity of Craig; (3) Wolf Creek and Anthracite Range, including the coal beds exposed on the eastern rim of the main basin from Yampa River as far. north as the coals have been traced; (4) Lower Elkhead and Fortification creeks, including the lignite coals of the Laramie formation and lying in the structural center of the main basin of the field.

\section{TWENTYMILE BASIN.}

This structural basin includes the coal beds exposed on Oak, Trout, Middle, and Fish creeks and a small area on and near Yampa River about 2 miles west of Pool post-office. In this basin all the coal-bearing rocks dip in general toward its center, which is Twentymile Park, and thus they form a single structural basin. Each creek valley, however, forms a distinct district or commercial unit, for the developments in a single valley are in the main subject to similar conditions of accessibility and convenience to market, and these conditions are usually different from those of adjacent valleys in the same structural basin.

Oak Creek district.--Coal seams outcrop along the upper valley of Oak Crack for a distance of at least 9 miles. The valley of this creek practically outlines the extreme southeastern limit of the coal field. Coal beds occur in the high bluff north of Pinnacle postoffice and probably they are continuous along the bluff on the north side of the creek as far as the Yampa and Eddy road. By the side of this road in a small tributary valley of Oak Creek there are a number of openings, which are generally known as the James mine ( $W$ on map, PI. VI). There is some doubt as to the position of the beds opened in these mines, but they probably belong to the lower coal group. Openings have been made on three seams, separated by intervals of about 35 feet each. The coal dips about $10^{\circ} \mathrm{NW}$. The principal mine is on the uppermost bed that is exposed. An entry has been driven in on the coal bed for some distance, and considerable coal has been mined for local use and to supply the growing town of Yampa. The mine was not in operation at the time it was visited, and a complete section could not be obtained. The exposed part of the bed is as follows: 
Shale, dark.

Section of upper cort bed at. Jomes mine.

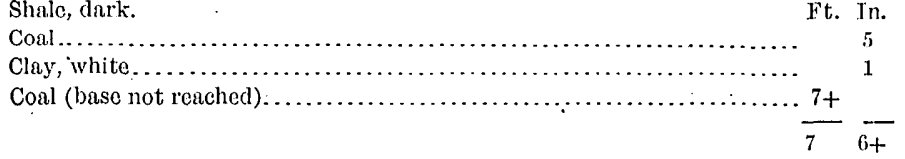

The next or middle coal seam was not accessible, and consequently was not measured: An incomplete section of the lower seam, as shown in the principal opening at this point, is as follows:

Section of lower coal bed at James mine.

Tt. In.

Coal, good, bright.......................................... 2

Coal, dirty . . . . . . . .

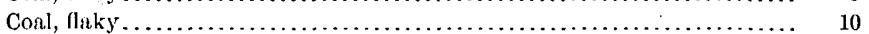

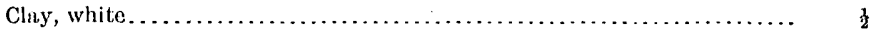

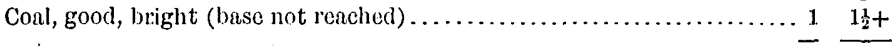

Farther down the creek a coal bed also belonging to the lower conl group is opened by the side of the road leading from Yampa to Eddy post-office. This opening is generally known in the region as the Shuster mine (A). An entry has been driven in on the coal bed for several hundred feet and a large amount of coal has been taken out for local use. At the time of the visit the coal was being hauled from this point to Steamboat Springs for use in the electric-light plant. The section of the conl bed in this mine is as follows:

Section of coal bed in Shuster mine.

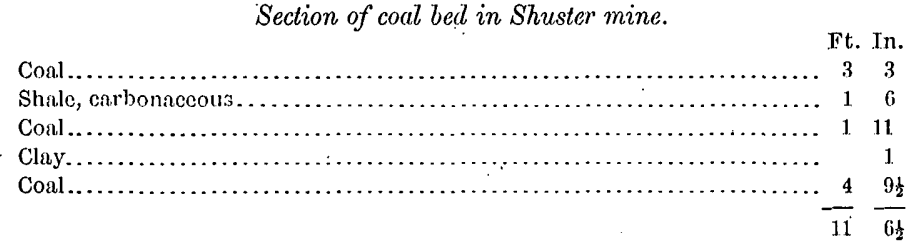

The seam dips in general to the northwest, at an angle of about $20^{\circ}$. A sample was taken at this mine for chemical analysis. It was obtained by making a cut across the face of the coal in one of the rooms of the mine, and it includes all of the two lower benches of the coal, exclusive of the clay parting.

\section{Analysis of coal (sample A) from Shuster mine.a}

[F. M. Stanton, analyst.]

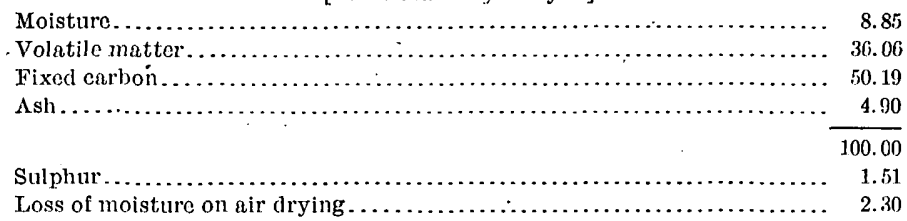

Below the Shuster mine the coal beds of the lower group have been opened in a number of places along Oak Creek, but the most important development has been at the point where the Oak Creek leaves the coal field and turns east toward Yampa River. Here a great deal of mining has been done in the past. The only mine now operating at this point is one on the south side of the creek, owned and operated by the Steamboat Springs Electric Company $(\mathrm{X})$. The coal is considerably crushed. At the time this mine was visited it was

$a$ Samples for analysis were taken in a uniform manner throughout the field. $A$ face of the coal seam was first cut down so as to expose fresh coal. A channel was then cut across the whole seam, only that part which would be saved in actual mining or such as appeared to be good merchantable coal being saved for the sample, and all bony seams and partings being thrown out. 'This large sample was pnlverized and quartered down to convenient size at the mine and there sealed in an air-tight galvanizedverized and quartered down to convenient size at the mine and there sealed in an air-tight galvanized-
iron can. The analy ses were made under the supervision of Prof. N. W. Lord, of the Ohio State University, at the laboratory of the United States Geological Survey coal-testing plani, St. Louis, Mo. 
impossible to secure a detailed measurement, but the coal bed appears to be the same as that operated at the Shuster mine and to have a similar thickness. Six coal seams show on the north side of the creek in a section about 230 feet thick. The sandstone and coal beds dip about $45^{\circ} \mathrm{W}$.

The middle coal group outcrops near the summit of the bluff on the west side of Oak Creek, about 500 feet above the Shuster mine. The outcrops appears to be continuous from this point to Eddy post-office, but only prospect pits were found, and these seemed to indicate that the coal beds are not so valuable as are those of the lower group in this locality.

Trout Creek Canyon district.-A number of coal seams are exposed on upper Trout Creek near the mouth of the canyon, about 6 miles above Eddy post-office. The seams are opened near the road that crosses from Oak Creek, and they probably occur in the middle coal group. About three-fourths of a mile above this point another group of coal seams has been prospected. These probably belong to the lower group, which is thought to follow down Trout Creek on the crests of the ridges in approximately horizontal position from Pinnacle postoffice to near the mouth of Trout Creek Canyon, where this coal group suddenly dips below water level. On one of these seams of the lower group an entry has been driven in 40 feet, showing 6 feet 3 inches of coal (B). The coal was slightly weathered, but a sample cut across the face of the seam gave the following analysis:

\section{Analysis of lower coal (sample B) in Trout Creek Canyon.}

[F. M. Stanton, analyst.]

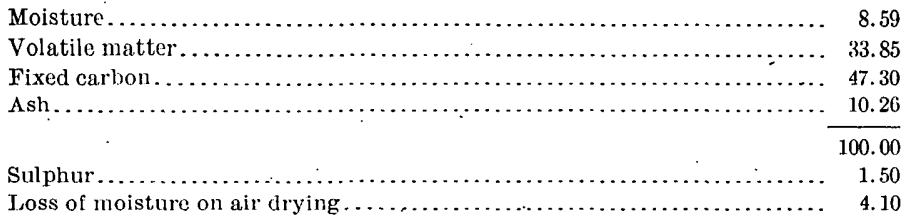

Eddy district.-The middle and lower coal groups cross Trout Creek in the vicinity of Eddy post-office, and mines and prospects show that both groups carry workable coals. A coal bed of the lower group is opened at the Jones mine, on the north side of Trout Creek, $1 \frac{1}{4}$ miles below Eddy. The coal is nearly horizontal and shows the following section:

Section of coal bed at Jones mine.

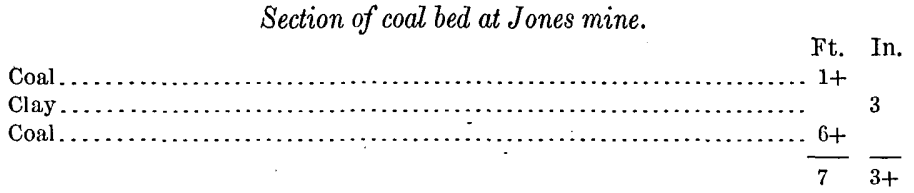

This coal group contains a number of thick beds, as shown by the section on the county road which crosses Trout Creek 2 miles below Eddy.

The middle group of coals has been opened on the Hutchinson property on Middle Creek (C), just above the crossing of the public road west of Eddy. The principal seams shows a thickness of 9 feet 6 inches of clear coal in the mine near Mrs. Hutchinson's house. A sample for analysis was taken at a new opening a few rods down the creek. This sample was obtained by making a cut across the lower part of the seam and represents a thickness of 5 feet of coal. The analysis is as follows:

\section{Analysis of coal (sample C) from Hutchinson mine.}

\section{[F. M. Stanton, analyst.]}

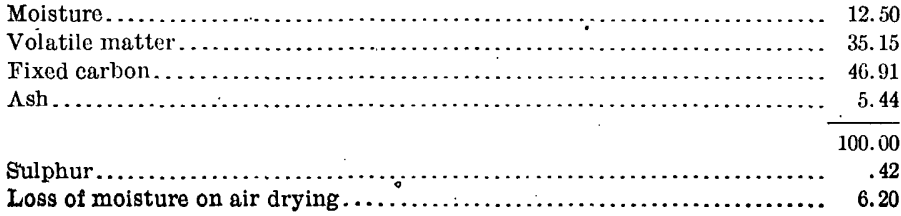


Another seam, 25 feet below the Hutchinson seam, has been opened a little farther down the creek, and to judge from the appearąnce of the dump heap, considerable coal has been taken from it. This bed shows a thickness of 6 feet 2 inches of clear coal. There are many other openings and prospects in this vicinity, but those given are representative of the larger seams.

Pool district.-At the mouth of Trout Creek Twenty-mile Basin extends to the north in the form of a narrow syncline and the coals of the middle and lower groups cross Yampa River. The situation will probably be best understood by reference to the map. Seams of both groups have been opened in this district. A lower seam of the middle group is opened at the McCroskey mine (D), on the north side of the river, a little less than 2 miles west of Pool post-office. At the time of visit this was the only mine being worked in the district. The coal is used for domestic purposes and is hauled as far as Steamboat Springs. The mine is driven in 400 feet and the following measurements were made:

Section of coal bed at McCroskey mine, on Yampa River.

Ft. In.

Sandstone roof.

26

to 3

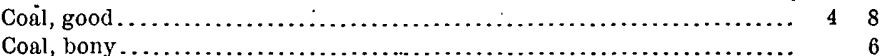

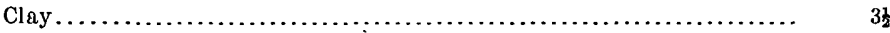

Coal, good..................................................... 311

Coal, bony ............................................... 1

Sandstone floor.

$\overline{10} \overline{62}$

The following analysis was made from a sample representing all the good coal of this seam:

Analysis of coal (sample D) from the $\mathrm{McC}$ roskey mine.

[F. M. Stanton, analyst.]

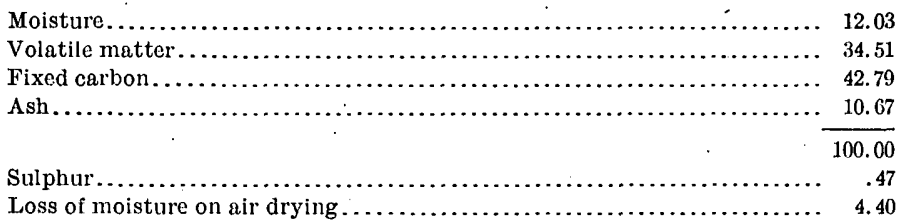

This coal is one of several seams of this group showing in the face of the hill just north of the road. The amount of available coal at this point is, however, limited by the sharp tilting up of the point of the syncline a short distance north of this mine.

The lower coal group is well shown in the tilted sandstones along the stage road just east of Tow Canyon. Several of the seams have been burned in outcrop.

Coals of both the middle and lower groups have been opened south of the river. A seam of the lower group is opened at the old Brooks mine, situated in a gulch that opens into Trout Creek from the southwest near its junction with Yampa River. This seam is slightly over 5 feet thick and shows a face of solid, bright coal lying between massive beds of white sandstone. The middle group is developed in an old opening known as the Hitchins mine $(\mathrm{Y})$, one-half mile southwest of the Brooks mine, in the same gulch and about .250 feet above the creek valley. This is a seam 10 or 11 feet thick. When visited the entrance was locked and the roof in bad condition.

A small structural basin of coals of the lower group lies on the summits of the ridges a few miles northwest of Pool post-office. These coals have been prospected by drifts in a number of places and are reported to be of workable thickness, but the prospects were not visited. The basin is a comparatively small one. 
The western side of Twentymile Park is bounded by ridges of steeply upturned strata. Fish Creek cuts through this wall in a sharp canyon a short distance below Dunkley postoffice. In this canyon the section of nearly the whole coal-bearing series is well exposed within a short distance. Seams of the lower and middle groups have been worked for local use. An old entry on a seam of the middle group measured 12 feet, more or less, of coal, overlying 8 feet of thin-bedded sandstone and shale. Under this is another seam of coal 3 feet thick. The dip is $56^{\circ} \mathrm{E}$.

The coals of the upper group are exposed in many places in Twentymile Park: The representation on the map of the outcrop of this coal group is only approximate, for these coals lie above the more massive beds of sandstones of the coal-bearing series and are themselves covered by beds of soft and easily eroded shale. As both the upper coals and the overlying shale in large part occupy an approximately horizontal position, slight undulations of these beds may bring these coals to outcrop almost anywhere in the shale valleys and, on the other hand, may also carry the same coal seams to a considerable depth under the shale cover, without necessarily showing in the sagebrush prairic any surface indication of this structure. This is true of the upper coal group throughout the field, with the exception of the few districts in which the coals are tilted at such high angles as to make their outcrop a fairly definite line. The inferior quality of the coal in some of these seams that have been opened is probably due to lack of sufficient cover to have afforded protection from atmospheric agencies. The probability is, however, that a large proportion of this coal group lies sufficiently buried to have preserved the coal from such deterioration. The seams most deeply buried are not the ones most readily opened in prospecting.

\section{WILLIAMS FORK MOUNTAINS.}

This general district includes all the coals on the south side of the main field and west of Twentymile basin. The coals are exposed in outcrop on the crest and flanks of Williams Fork Mountains, which constitute the divide between Williams Fork and Yampa River. This definition of the district includes the Sage Creek coals, although these extend in outcrop, following the Sage Creek anticline, considerably north of the general trend of the coal groups of this district. From Sage Creek westward the outcrop of the three coal groups approximately parallels the crest of the Williams Fork divide, but is complicated by cross folds near the junction of Yampa River and Williams Fork. The cross folds are repeated for 8 or 10 miles to the west of the area shown in the map (Pl. VI) and finally disappear beneath the overlying strata in the vicinity of Lay post-office.

Sage Creek Canyon.-A little over 5 miles south of Hayden, Sage Creek emerges from a canyon eroded on the axis of a minor anticlinal fold. This fold, like that on the west of Twentymile Park, is not symmetrical; and has a steep dip on the east flank and a much lighter dip to the west. The three coal groups are exposed as indicated on the map. On the north slope a seam of the upper group has been opened and worked for the Hayden market. In the canyon two seams of the middle group have been opened by drifts and are now being worked for domestic use in and about Hayden. One of these seams $(\mathrm{N})$ of the middle group measured 6 feet 10 inches of clear coal, and a sample for analysis representing the whole face was taken at the breast of a 300 -foot drift. This seam dips $28^{\circ} \mathrm{NE}$. The analysis is as follows:

Analysis of coal (Sample N) from the Barnes mine.

[F. M. Stanton, analyst.]

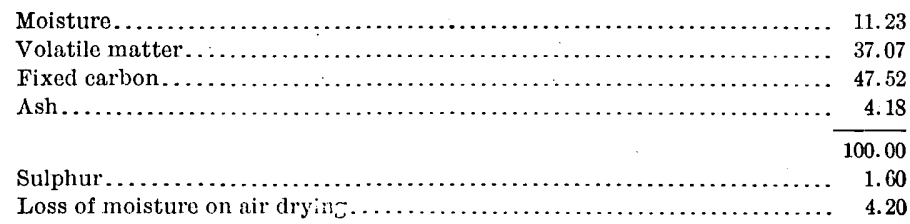


About 75 feet below this seam, in the same group, is another seam (M) which measured 11 feet 5 inches. A sample of this conl, for analysis representative of the whole face, was also taken:

$$
\text { Analysis of 11-foot seam (Sample M) in Sage Canyon. }
$$

[F. M. Stanton, analyst.]

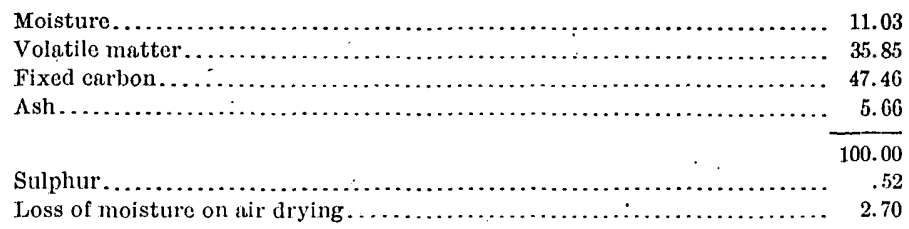

These openings are on the eastern or steep side of the anticline. About 11 miles up the creck, on a small side gulch from the east, is a prospect on a seam of the lower group, showing alout 10 feet of coal. This dips at an angle of $35^{\circ} \mathrm{NE}$.

Dry Creek district.-The coals exposed along Dry Creek are of the upper group and lie agninst the west flank of the Sage Creek anticline. These coals have been opened at a number of places, and one entry $(P)$ was being worked to supply the Hayden market at the time of visit. A sample of this seam, representing 7 feet 10 inches of solid conl that was being mined, was taken for analysis:

\section{Analysis of coal (Sample P) from Dry Creek.}

[F. M. Stanton, analyst.]

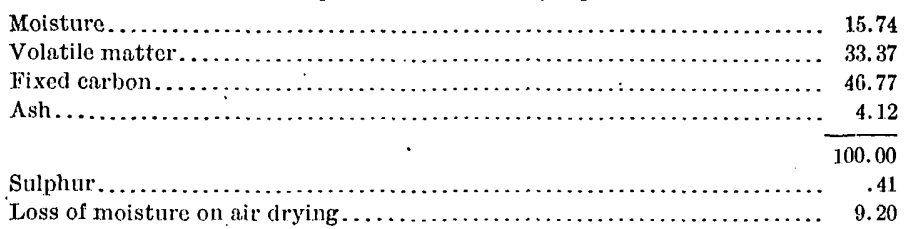

The whole section of the upper group as exposed in this vicinity was measured as follows:

Section of upper coal group on Dry Creek.

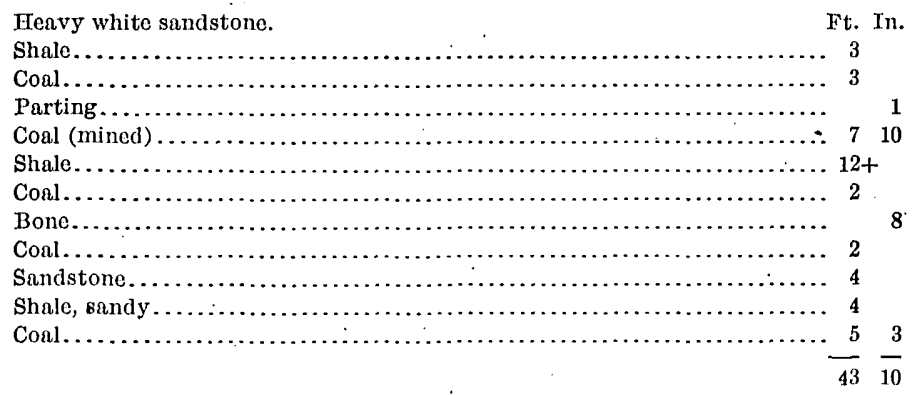

From the Dry Creek openings the road runs in a southerly directon across the Williams Fork divide and thence down Hayden Gulch. On the north side of the summit the rond follows the outcrop of the upper coal group for several miles. These coals have been largely burned at the outcrop, as have many of the seams outcropping to the south and west of this district. In such cases the coals are marked by banks of reddened shale and sandstone and often by clinkers.

Williams Fork divide district.-On the south or Williams Fork side of the summit of the public road the trend of outcrop changes and all three coal groups turn across Hayden Gulch, as is represented on the map. About 1 mile from the mouth of this gulch openings have been made on seams of the lower group, which have been worked by the settlers from 
Williams Fork. These workings are known as the Green and the Scott mines. The Scott mine exposes a seam of 9 feet 2 inches of good coal, overlain by 4 feet of shale. This was worked out in a large chamber, the roof of which was in a dangerous condition when visited. The Green seam $(Q)$ waș opened by an entry ending in a chamber and exposes a fine face of coal 10 feet thick. A sample from the Green seam, representative of the whole face as mined, shows the following analysis:

Analysis of coal (Sample Q) from the Green seam, Hayden Gulch.

[F. M. Stanton, analyst.]

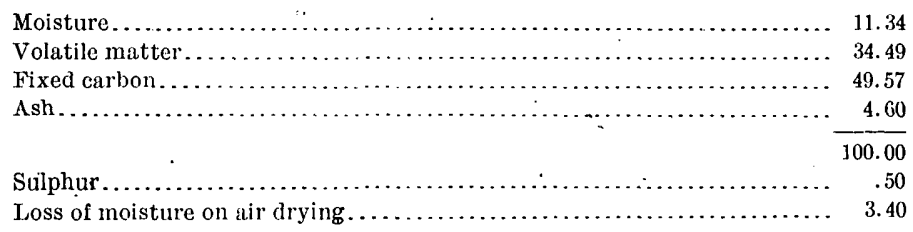

From Hayden Gulch the outcrops of the lower and middle coal groups extend westward on the south slope of Williams Fork divide. The coals have been prospected at many points along this belt, but nowhere have they been opened to any considerable extent. These outcrops probably represent a large quantity of workable coal, having a very uniform light dip to the north. The outcrops. are accessible in many gulches that extend back from Williams Fork.

In the vicinity of Hamilton post-office, on the south side of the river, some coals are exposed that are thought to belong to the lower group. These appear to be small outlying basins, a portion of the complication of folds lying between Williams Fork and Axial Basin. The Kellog coal bank, 5 miles south and a little east of Hamilton, was visited, as were also a number of prospects on thick seams in the same locality. The opening on the Kellog bank is a drift 200 feet in and shows 15 feet of solid coal, with coal roof and coal floor.

Lower Yampa district.-Near the junction of Williams Fork and Yampa River a large number of prospect pits and drifts and several banks to supply the local demand have been opened. These are on seams of all three coal groups. Among these a number of prospect drifts, locally known as the Greeley group, have been opened in the canyon of Yampa River. The openings on this property were in bad condition, owing to caving, but exposed a number of thick seams of coal, representative of the lower coal group at this point. Approximate measurements show one seam of 5 feet 8 inches of solid coal, another of 7 feet of coal with a 6-inch bony parting near the top, and still another seam 11 to 13 feet thick.

The Wise and Ratcliff banks $(R)$, on Williams Fork, near its mouth, are on seams of the middle coal group. The Wise bank shows 8 feet of coal, with a shale roof, but the actual. thickness of the seam may be somewhat greater. The Ratcliff bank, on a school section, was being worked under lease at the time of visit and most of the coal was being hauled to Craig. The opening was driven in 400 feet, and measurements of the seam showed 10 feet 7 inches of coal without partings, of which, however, the lower 16 inches were not mined. The mine has been worked in large rooms and the roof has caved badly in places. It is timbered with long poles set about 3 feet apart and is fitted with a 1-ton car and a small wooden frame tipple. A 4-foot seam is reported, lying about 50 feet below this seam, and both appear to overlie stratigraphically the seam of the Wise bank. The upper coal group is opened at the Joseph Haubrich bank, on Yampa River, just above the forks. The bank showed a thickness of 6 feet 4 inches of coal and has a shale roof. This coal lies just above the massive white sandstone that marks the base of the upper group.

About halfway between the forks of Yampa River and the town of Craig, near Woods Ranch, or "Big Bottom," Yampa River cuts through i. low anticlinal fola and exposes coals of the middle group along its banks (S). A number of valuable seams are probably accessible here. 
Craig district.-Near Craig are two openings on seams presumably of the upper coal group, namely, the Walker bank (U) and the Kimberly bank (T). The Walker bank is on the south side of the river, about 4 miles southeast of Craig. The seam measures 8 feet, and possibly more, of apparently good solid coal. The coal breaks out in cubical joint blocks and is without partings. This bank was opened sixteen years ago, and is usually worked during the winter season. Another seam, exposed about 25 feet lower down, is apparently about 4 feet thick.

The Kimberly bank (' $\mathrm{T}$ ) is on the north side of the river and about 2 miles enst of Craig, near the stage road. The seam measured 8 feet of solid coal and is probably slightly thicker, as neither roof nor floor was exposed. It dips $14^{\circ} \mathrm{N}$. and has been opened by a slope starting from the surface outcrop. The coal is much weathered near the entrance, but distinctly improves in quality toward the end of the 150-foot slope.

Lay district.-Westward from the mouth of Williams Fork the intervals between the several coal groups decrease notably. A short distance east of Lay the coals of the three groups are embraced within a vertical range of 800 feet. The middle and upper groups in this locality have been prospected but little. Near Lay post-office, within $\Omega$ vertical range of 250 feet, three coal seams have been opened whose aggregate thickness is 41 feet. - An additional 4-foot seam is believed to exist within the same range and a 10-foot seam 60 feet higher, making in all 55 feet of coal within a range of 320 feet.

An entry in the lowest seam (called the Sweeney tunnel) exposes 7 feet 10 inches of coal, separated into two nearly equal parts. by a 12 -inch streak of bone. Beneath a thick layer of bone now used as the floor of the mine another bench of good conl 4 feet thick is reported. One hundred feet above the Sweeney seam is the so-called Peacock seam. Here are 9 feet of coal, unfortunately covered by a poor roof of clay. A 4-inch layer of bone appears near the top, and locally another. is found near the bottom. The coal is otherwise clear, bright, and very tough. One hundred feet higher is a double seam containing 20 feet 3 inches of coal, divided into two nearly equal parts by a 15-inch layer of shale. Postmaster A. G. Wallihan, of Lay, the local representative of the Wisconsin Fuel and Mining Company, has driven a brond tunnel about 200 feet into the lower part of this seam. Blacksmith's coal is sent from this mine as far as Hayden, a distance of 45 miles. Simple tests made by Mr. Wallihan lead to the hope that this will prove to be a good coking coal.

\section{WOLF CREEK AND ANTHRACITE RANGE.}

The rocks and coal in this district outcrop in a belt of general north-south direction, extending from Grassy Gap, on the west side of Twentymile Park; to the flanks of Sand Mountain, on the enst side of California Park, a distance of about 25 miles. The Conl Measures dip toward the west and pass beneath the black shale that forms the rolling prairie land of Hayden Valley. This district includes the coals both north and south of Yampa River, where the three groups cross in the canyon above Hayden. On the north side of Yampa River these are known as the Wolf Creek coals. North of Wolf Mountain this district includes the various coal properties of Anthracite Range.

Wolf Creek Valley.-Wolf Creek drains to the south from Wolf Mountain and joins Yampa River 7 miles above Hayden. In its upper course it flows in a steep, narrow canyon through the massive sandstones that underlie the coal groups. Below this canyon it cuts diagonally across the outcrop of the lower coal group and these coals are well exposed in a number of prospect drifts. One entry, about 40 feet in, showed a face of 4 feet 2 inches of good coal under a shale roof. Below this the stream bed follows near the outcrop of the middle coal group for about 4 miles and these coals are well exposed in a number of recent openings. On Yampa River, opposite the mouth of Wolf Creek, openings have been made on three seams of t'ze middle group, which serve as a good typical section of the group for this vicinity. The uppermost seam measures $2 \frac{1}{2}$ feet at its outcrop. Under this are about 70 feet of sandstone and shale, and then the coal known as the Wadge seam, which measured 8 feet 3 inches of clean, bright coal, without parting. This coal 
seam is locally known as one of the most perfect in the field, as to quality of coal, character of the seam, and its ability to withstand weathering. A sample for analysis was taken at the breast of an old working $(\mathrm{K})$ about 250 feet in and a second sample of the same seam in a recently opened drift $(O)$. Both of these represent the whole face of the seam -8 feet 3 inches of coal.

Analysis of coal from Wailye seam, on Yampa River.

[F. M. Stanton, analyst.]

\begin{tabular}{|c|c|c|}
\hline$\cdot$ & Sample K. & Sample O. \\
\hline Moisture.......... & 9.49 & 10.59 \\
\hline Volatile matter.... & 37.89 & 36.75 \\
\hline 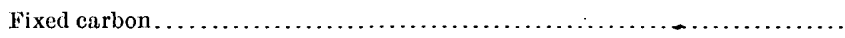 & 47.04 & 47. 53 \\
\hline \multirow[t]{2}{*}{ 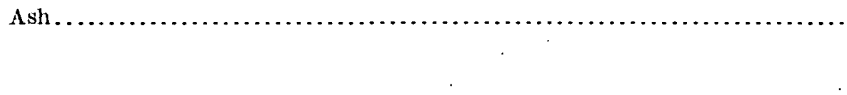 } & 5.58 & 5.13 \\
\hline & 100.00 & 100.00 \\
\hline Sulphur....................................... & .41 & .44 \\
\hline Loss of moisture on air dryi $-\mathrm{g} . \ldots \ldots \ldots \ldots \ldots \ldots \ldots$ & 2.40 & 4. $00 \mathrm{~s}$ \\
\hline
\end{tabular}

About 90 feet stratigraphically below the Wadge seam is a thick seam of coal opened by an entry driven under the stage road on the north side of the river. This seam measures 16 feet 3 inches, and possibly a little more, of which the lower 7 feet of coal have been mined out. This was separated from the upper 8 feet of coal by 15 inches of sandy parting.

On a side gulch entering Wolf Creek from the east, 2 miles above the river, a seam of the lower group has been opened, exposing coal at least 6 feet 4 inches thick, with two or three thin partings. The partings, however, are not constant. Just over the divide to the east, on Butcherknife Creek, are several openings on coals of this same group. An entry recently made on Mr. Gartman's property (L) exposed coal measuring as follows:

Section of coal on Gartman property.

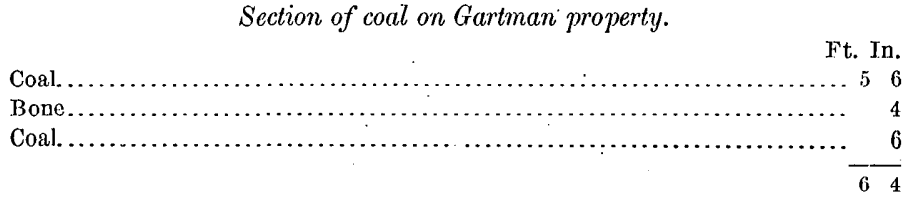

A sample representing all but the 4 inches of bone showed the following analysis:

Analysis of coal (Sample L) from Gartman entry, on Butcherknife Creek.

[F. M. Stanton, analyst.]

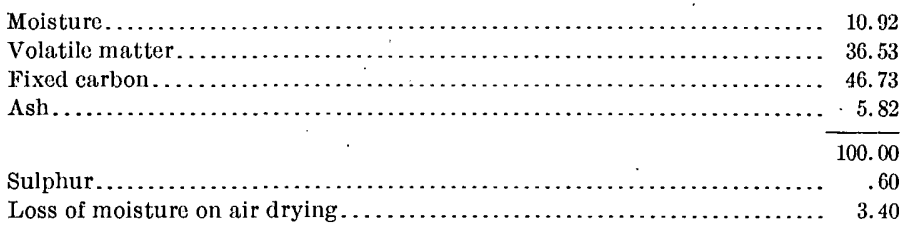

Anthracite field.-Intrusive igneous rocks of several types cut the coal-bearing beds at many points. Within the coal field the district in which this activity was greatest centers about Pilot Knob and Wolf Mountain. By far the most common of these intrusive roçks is the basalt that composes Pilot Knob, Wolf Mountain, Hooker Mountain, and many lesser peaks and ridges of this vicinity. The whole district is known as the Anthracite Range. 'The rock itself is a typical olivine-basalt. The basaltic peaks have the appearance of huge dikes, probably marking the fissures through which this rock ascended. Smaller dikes of approximately vertical position radiate from the larger masses, and sills of the same material are found interbedded with the sediments in many places. 
The heat accompanying the intrusion of the molten rock has influenced to varying degrees the character of near-by coals. In general the result of this baking process has been the driving off of the volatile hydrocarbons. In this way all intermediate grades of coal ranging from bituminous to anthracite have been fo:med.

It is evident that where the source of the heat was fairly uniform in its relation to the coul seams the resulting alteration of the conl may be expected to be correspondingly uniform over a like area. This result is best attained in the cases of the intruded sills. Two reasons may be given for the fact that many of these intrusions have taken the form of sheets lying parallel to the coal seams: (1) The basalt, when molten, is a comparatively fluid magma and more readily forces its way into thin crevices than would the magmas of more acidic rocks. (2) These crevices would more easily open in the sedimentary series between the beds than across them.

On the other hand, the intruded lava sheets do not seem to have exerted an influence through more than 50 to 70 feet of intervening strata, and probably not often so far as this. A contact of coal and lava would probably have resulted in burning or complete coking of the coal. In order that any given seam may be changed to good anthracite there is necessary a comparatively delicate adjustment of this relation of coal seam and lava sheet, the achievement of which depends on purely accidental circumstances.

The property known as the Crawford tract is situated on the county road that crosses the Anthracite Range west of Anthracite post-office. Openings on the seams of this tract furnish perhaps the best known of the anthracized coals. Three entries are located close to the public road. The two uppermost on the road and one on a side gulch to the north appear to be on the same seam. This measures at least 11 feet in thickness, with a parting of 6 to 8 inches near its middle. A massive sheet of basalt is plainly exposed on the north side of the creek, dipping under the lower seam at an interval of about 50 feet. The coal seam shows varying degrees of anthracization. It is thought that this seam corresponds to the lowest seam of the middle coal group as exposed at the mouth of Wolf Creek, both in details of its measurements and in position at the base of the group. Samples $(E$ and $G)$ from two entries on this seam were taken for analysis. They were obtained by making cuts across the face from top to bottom of the lower bench of 6 to 7 feet of coal.

Analyses of coals from 11-foot seam on Crawford tract.

[F. M. Stanton, analyst.]

\begin{tabular}{|c|c|c|}
\hline . & Sumple E. & Sainple G. \\
\hline Moisture $\ldots \ldots \ldots \ldots \ldots \ldots \ldots \ldots \ldots \ldots \ldots$ & $\begin{array}{r}\text { Per cent. } \\
6.94\end{array}$ & $\begin{array}{l}\text { Per cent. } \\
6.85\end{array}$ \\
\hline 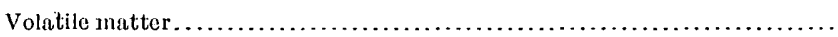 & 3.42 & 23.84 \\
\hline 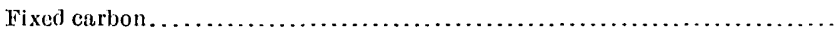 & 75.61 & 60.00 \\
\hline 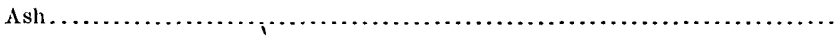 & 14.03 & 9. 31 \\
\hline & 100.00 & $100: 00$ \\
\hline 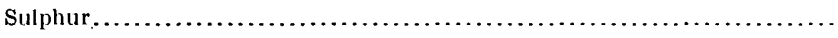 & .57 & .55 \\
\hline 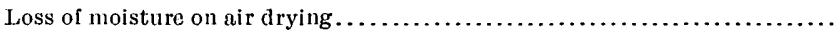 & 4. 20 & 4. 20 \\
\hline
\end{tabular}

A comparison of these results with analyses of typical Pennsylvania coals, both anthracite and bituminous, shows that Sample $\mathrm{E}$ is an exceptionally high grade of anthracite, so far as its percentages of fixed carbon and volatile matter are concerned, but that its commercial value as such is materially impaired by the high percentage of ash.

Sample $G$ was taken from an entry on the same seam, only 40 rods distant. Its composition would class it as a bituminous coal of good quality.

A smaller seam, measuring about 28 inches, has been opened in a number of places a short distance beneath the large seam just described. Reports of analyses of this coal 
show it to be anthracite of excellent quality, containing only a normal percentage of ash. No statement can be made as to its probable extent.

The lowest opening on the road is on a seam 100 feet or more stratigraphically higher in the series than the seam just described. This coal measured 6 feet 2 inches, without partings, at the breast of a 140-foot drift, and is supposed to be the Wadge seam. A sample (F) cut from the whole face shows on analysis a composition very similar to that of the Wadge coal. This analysis is as follows:

Analysis of coal (Sample F) from bituminous seam on Crawford tract.

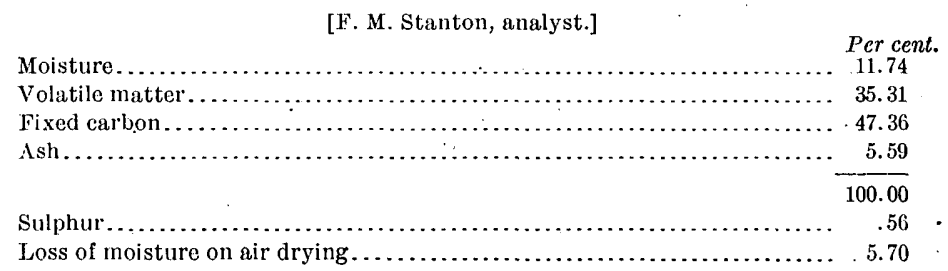

To the south and east of the gap above the Crawford mines and near the road are severa openings on coal seams of the middle group, so badly fallen in that the coals were not measured. One tunnel near the road was reported to have opened a thick seam of coal that ran high in ash, and it is thought that this may be the same seam as the thicker one opened in the Crawford property, which also carries a considerable percentage of ash, as shown by analyses $\mathrm{E}$ and $\mathrm{G}$ on page - .

A seam of the lower coal group has been opened and mined for domestic use on the face of a steep ridge in a school section to the east of the openings last mentioned. This opening showed about 8 feet of solid coal, but could not be measured exactly, as the lower part of the coal was standing in water. The seam dips about $10^{\circ} \mathrm{W}$. From this point northward the lower coal group outcrops along the east side of Pilot Knob and is exposed in the openings on the head of Miller Gulch and in those near the Ducey tunnel. On Miller Gulch a recently opened prospect was sampled for analysis (H). This sample was cut across the face of a seam 4 feet 1 inch thick.

\section{Analysis of coal (Sample H) from prospect at head of Miller Gulch.}

[F. M. Stanton, analyst.]

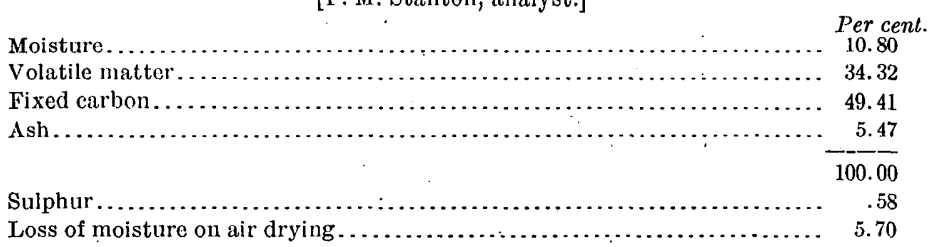

Th.e Ducey tunnel is on the east side of Pilot Knob. It has been worked for about nine years to supply the settlers on the head of Deep Creek, and the coal has been hauled as far as Hahns Peak. The old tunnel showed 5 feet of solid block coal dipping lightly to the west. The coal does not appear to have been affected by its proximity to the huge basalt mass of Pilot Knob. Fifty feet above the old tunnel a seam having a thickness of 5 feet 2 inches has recently been opened.

About 3 miles northeast of Pilot Knob a thick sheet of basalt, known as the "rim rock," is exposed, lying in a nearly horizontal position and interbedded with the lower coal group. The property known as the Shelton tract overlies this intruded sheet. Coals of this tract have been extensively prospected, both by pits and bore holes, and anthracite is reported to have been found over most of the field that lies directly above the basalt sheet. The outcropping rim of the sheet is continuous for a number of miles to the north and it appears to occupy a single horizon in the sedimentary series. If this is true, its effect on the overlying coal seams may have been uniform over a very considerable area. 
The outcrop of the coal-bearing series continues, in part, at least, from the "rim rock" northward along the east side of California Park, lapping against the slopes of Sand Mountain. Little is known concerning the coal in this extremity of the field, for much of the ground is covered by débris of igneous rocks.

The field within which the three coal groups are known to have been aflected in places by the heat from the intrusion of igneous rocks is probably limited to about 25 square miles. 'This estimate does not include the Quaker Mountain district, whose coal seams are cons.dered to be of later or Laramie age and in most cases of inferior quality to the older seams of the field, although, as explained in a later paragraph, some of these Laramie coals have been altered to anthracite coal. Of this area of 25 square miles a considerable portion is occupied by the basalt, both as rock in place and in the form of heavy talus cover. The actual area in which anthracite coal is now known to be present or in which conditions seem favorable for its occurrence probably does not exced 10 square miles.

\section{LOWER ELKHEAD AND FORTIFICATION CREEKS.}

The center of the main Yampa field, as mapped, is occupied by a thick series of slightly consolidated beds of light-colored sands and clays, containing many coal seams. Th.s formation appears to lie conformably over the lower beds of Montana age, and, as a few marine shells were found in it north of Hayden, it seems probable that it is of Laramie age. The conl that it contains has been prospected somewhat and in one case at least has been mined for local use.

The Seymour opening (Z), on Dry Fork of Little Bear Creek, a tributary of Fortification Creek northeast of Craig, is on a thick seam of this coal. The roof is a compact blue clay, well exposed for a thickness of 6 feet. This seam of solid, black, bright coal, at least 17 feet thick, shows for 150 feet in natural exposure in the creek bank near by. The coal itself, however, seems to be of comparatively light weight.

The coals exposed at the "potholes" of Elkhead Creek, although in some cases anthracized by the intrusion of igneous sheets, belong to the unconsolidated beds of the Laramie. To this formation also belong most of the coals on Quaker Mountain and some seams on the north side of California Park. At the extreme east end of Quaker Mountain, however, several prospects and tunnels of the Egeria Coal Company (V) have opened seams of coal whose proper class:fication is not certain. From the character of the associated shales and sandstones it is thought that they probably belong to the Laramie, but owing to the fact that the middle and upper groups of the Montana coals have been lost sight of in this vicinity under the basalt cover, this opening may be on one of these older coal seams.

Bull. 285-06-16 


\section{THE ENGLE COAL FIELD, NEW MEXICO.}

By W. T. Lee.

The Engle coal region takes its name from the town of Engle, a station on the Atchison, Topeka and Santa Fe Railway about 100 miles north of El Paso, Tex. It is the southernmost of the small coal areas of central New Mexico and lies about 70 miles south of the Carthage area, in which occur the southernmost productive mines of this region.

The coal outcrops in the western limb of the great syncline of the Jornada del Muerto, and the eastward-dipping beds disappear beneath the surface detritus occupying the center of that syncline. The western edge of the trough in this region consists of the Caballos and the Fra Cristobal ranges, separated by a gap several miles wide, in which the plain of the Jornada extends westward to the Rio Grande.

The geological formations are steeply upturned and are particularly well exposed in the Caballos Mountains. Those beneath the coal range in age from pre-Cambrian to Benton. The coal-bearing strata consist of sandstones and shales several thousand feet in thickness and occupy the gap between the Caballos and Fra Cristobal mountains west of Engle, extending north and south of this gap for several miles before they are finally covered by the surface detritus of the Jornada.

Lignite coal deposits occur at or near the base of the series, while the middle and upper Iayers contain large quantities of petrified wood. The upper part of the series is composed of red clay, sandstone, and conglomerate and has been mistaken by some for the "Red Beds," which occur at a lower horizon. These red strata, however, contain the bones of Triceratops, a reptile characteristic of latest Cretaceous time.

The relation of the Engle coal deposit to those farther north is not certainly known.' Its position in contact with the Benton suggests an early Cretaceous age, while the abundant plant remains, as wcll as the Triceratops, a supposed Laramie reptile, seem to correlate it with such later Cretaceous coal formations as occur in the Cerrillos or the Raton area.

Little development has been accomplished in the Engle area and its importance as a coal field is doubtful. Only one serious attempt has been made to open a mine. At the time of the writer's visit to this region, in the summer of 1905 , a shaft was being sunk on one of the veins at the base of the series, about 10 miles southwest of Engle. The coal is soft, resembling the lignite of other parts of New Mexico, and is apparently of good quality. The coal, so far as developed, is about 1 foot thick, although the carbonaceous shale associated with it is 2 or 3 feet thick. The prospect of finding a deposit of workable thickness was considered promising enough to warrant investigation.

The possible occurrence of coal in this locality assumes importance on account of its proximity to the proposed Government reservoir at Elephant Butte. The dam site of this reservoir is but a few miles from the coal outcrops. Coal in workable quantities would greatly facilitate the work of the Government in the construction of this reservoir, as well as benefit the large number of people that will settle in the vicinity after the reservoir is built. 


\title{
THE DURANGO-GALLUP COAL FIELD OF COLORADO AND NEW MEXICO. ${ }^{a}$
}

\author{
By F. C. Schrader.
}

\section{LOCATION.}

The Durango-Gallup coal field lies mainly in the northwestern part of New Mexico, but includes also a small area in the southwestern part of Colorido. As shown by the encircling outcrop of its coal-bearing rocks on the accompanying map $b$ (PI. VII), it extends from Durango, Colo., on the north, beyond Gallup and Mount Taylor in New Mexico, on the south, and from near the New Mexico-Arizona line, on the west, to Chama, Elvado, and the Sierra Nacimiento, near the longitude of Albuquerque, on the east.

It is situated in the great Plateau Province described by Powell and Dutton, and includes most of the upper part of the basin of Sun Juan River, which drains westward and forms one of the most important tributaries of the Colorndo. A small area in the southwestern part of the field, including the region about Gallup, also drains to the west by way of Rio Puerco and the Little Colorado. Although located mainly on the western slope, the field extends across the continental divide, whence the drainage from its southeastern border finds an outlet by way of Chama and San Jose rivers and the Rio Grande into the Gulf of Mexico.

- The area thus defined comprises the principal part of the coal field as known, but the coal-bearing rocks extend to the northwest and west into Utah and Arizona, and also to the south 50 or 60 miles beyond Gallup. As these outlying areas were not visited during last season, they will not be given further consideration in this paper.

Geographically the field may be characterized as a dissected plateau-a diversified land of mountains, buttes, mesas, terraces, ridges, scarps, valleys, canyons, and arroyos, in which the decper valleys are nearly 1,000 feet below the general upland level. 'The highest mountains are on the north and east, and from these summits the surface slopes gently to the west down the valley of San Juan River. The elevations, which vary from nearly 9,000 feet on the continental divide to 5,000 feet in San Juan Valley, are estimated to average about 6,500 feet.

The occurrence of coal at various points in the field has been known for more than half a century through the work of Wheeler, Hayden, and other early explorers. In 1892 R. C. Hills published in Mineral Resources of the United States an account of that part of the field which lies in Colorado, and in $1902 \mathrm{~L}$. S. Storrs prepared and published in the Twenty-second Annual Report of the Survey an account of the entire field in both Colorado and New Mexico.

Coal has been mined for a score or more years at Durango and Monero, in the northern part of the field, and at Gallup and Clarksville, in the southern part. The field as a whole is very important on account of its nearness to the mining centers of Arizona and the Southwest, where coal of any consequence is unknown.

$a$ This preliminary report is to be followed by a fuller description of the field, now in prepuration, which will appear as a bulletin of the Survey.

$b$ This map was prepared by Mr. M. K. Shaler. 


\section{GEOLOGY.}

In a broad way the Durango-Gallup coal field is a huge synclinal basin, with a length from north to south of 130 miles and a breadth from east to west of about 100 miles. The coal-bearing rocks form the rim of this bas.n and dip toward the center at angles varying from a small amount up to $70^{\circ}$ or $80^{\circ}$. The area of the basin is approximately 12,000 square miles, and probably it is all underlain by coal-bearing rocks, but in the center of the basin these are deeply covered by younger Tertiary rocks; except where their regular dips are disturbed by local folds or where they are exposed by the erosion of the deeper valleys. Although the area of the field is thus put at 12,000 square miles, it must be understood that in only a small part of this area is the coal near enough to the surface to be workable.

The coal-bearing rocks consist of shales, sandstones, clays, and a few limestone lentils and concretions, and they comprise five groups or formations of Upper Cretaceous age. Where upturned, even at gentle angles, as between Monero and Dulce, near Elvado, at La Plata, and at Gallup, they form hogback ridges, frequently rising several hundred feet above the valleys which occupy the intervening areas of softer shale. The generalized section of the coulbearing rocks is as follows:

Generalized section of coal and lignite bearing rocks of the Durango-Gallup field.

NORTHERN PART.

\begin{tabular}{|c|c|c|}
\hline Formution. & Character. & Thickness. \\
\hline Laramie (?)...$\ldots \ldots \ldots \ldots$ & $\begin{array}{l}\text { Friable gray sandstone with sandy shales, containing varia- } \\
\text { ble beds of black lignite (in all of the a rea mapped except- } \\
\text { ing the belt southward from Montezuma Creek, north of } \\
\text { Juanita, Colo.) and massive friable gray sandstone at } \\
\text { base. }\end{array}$ & $\begin{array}{l}\text { Feet. } \\
700-1,000\end{array}$ \\
\hline Lewis shale $a$ (Montana) .... & $\begin{array}{l}\text { Sandy greenish and drab shales, with sandy clays, contain- } \\
\text { ing occasional thin layers of impure limestone and concrc- } \\
\text { tionary masses at different horizons. }\end{array}$ & $2,000-2,500$ \\
\hline Mesaverde $a$ (Montana).... & $\begin{array}{l}\text { Shales witn interbedded whitish sandstone and variable } \\
\text { beds of coal (workable in the Durango, Monero, and Naci- } \\
\text { miento districts) with massive gray sandstone at basc. }\end{array}$ & $400-1,000$ \\
\hline $\begin{array}{l}\text { Mancos shale a (lower part } \\
\text { of Montana and upper part } \\
\text { of Colorado). }\end{array}$ & $\begin{array}{l}\text { Soft dark-gray or drab to almost black clay shales, with } \\
\text { thin lenses and coneretions of limestone. It includes near } \\
\text { the base an impure limestone bed } 3 \text { feet thick, which out- } \\
\text { crops between Horse Lake and the west front of Jemez } \\
\text { Peak, New Mexico, and which is the representative of the } \\
\text { Greenhorn limestone. }\end{array}$ & $1,200 \pm$ \\
\hline
\end{tabular}

\section{SOUTHERN PART.}

Shale and sandstone of Montana age, cmbracing the upper coal group.

Shale and sandstone of Montana age, containing the middle coal group near top.

Colorado shale, including lower coal group near top.
Gray clay shales, brown lignitic shales, variable sand stone beds and lignites.

Massive gray sandstone, buff to drab clay shales and lignites, massive argillaceous sandstones, d rab clay shales, with interbedded argillaceous sandstones, and massive gray sandstone at base.

Dark-gray to drab fossiliferous sandy shales, containing lignite beds of economic value only eastward from Marianna lake.
$2,000-3,000$

$500-800$

$500-1,000$

a Names of formations used by Dr. Whitman Cross in Lạ Plata folio (No.60), Geologic Atlas U.s.

\section{COAL.}

For convenience of description the territory examined is divided into eleven districts, which are located around the rim of the basin, as shown on the accompanying map (PI. VII). In the main these are not separate busins, but are areas in which the occurrence of the coal is fairly uniform and which are generally accessible from certain lines of approach. 


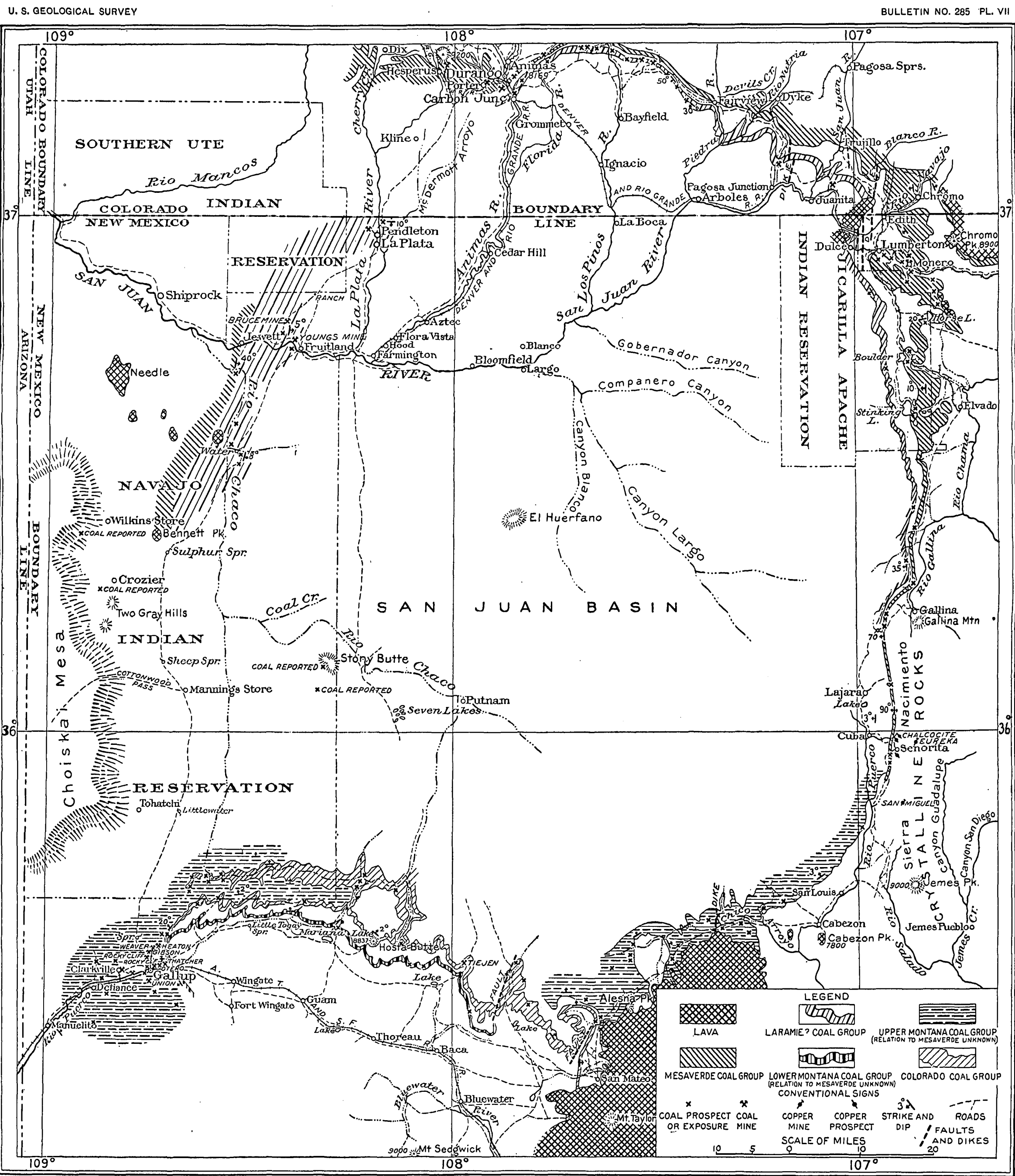

RECONNAISSANCE MAP OF DURANGO-GALLUP COAL FIELD, SHOWING OUTCROPS OF COAL-BEARING ROCKS. By F. C. Schrader and M. K. Shaler. 
DURANGO DISTRICT.

'The Durango district, one of the most important, and at present best developed in the field, is situated on the northern edge of the basin in the foothills of the San Juan Mountains and may be defined as extending from Florida River 25 miles westward, beyond Hesperus and the head of La Plata River. It includes Durango, Hesperus, and Porter and is traversed by the Denver and Rio Grande and the Rio Grande Southern railroads, which in general cross it in an east-west direction.

- The rocks of this distriat incline to the south at angles varying from $10^{\circ}$ to $30^{\circ}$, and are trenched by Animas River and its fellow tributaries of the San Juan, which have sunk their valleys about 1,500 feet below the general upland surface, exposing excellent sections of the rocks and coal beds.

The best coal of the district is found near the middle of the Mesaverde formation. The coal beds of this formation constitute a group that is interbedded with a great mass of whitish-yellow sandstone, which generally forms ridges and other conspicuous topographic features. 'These beds arc most extensively mined at Durango, Porter, and Hesperus. The bed mined by the City Coal Company, of Durango, in Horse Gulch, east of Animas River, is 3 or more feet in thickness, without a parting. The following is a partial section of the con bed in the old Champion mine, belonging to the same company, on the west side of the river:

Section of coal bed in Champion mine 2 miles southwest of Durango, Colo.

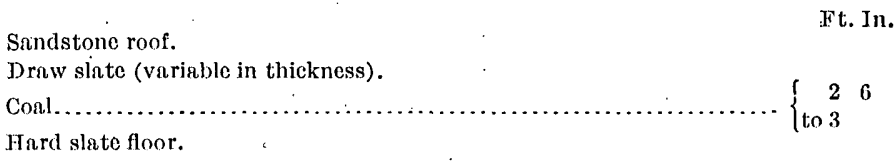

At Porter, 4 miles west of Durango, where the coal has been mined for about seventeen years, the following section was measured:

Section of coal beds in Porter mine, Porter, Colo.

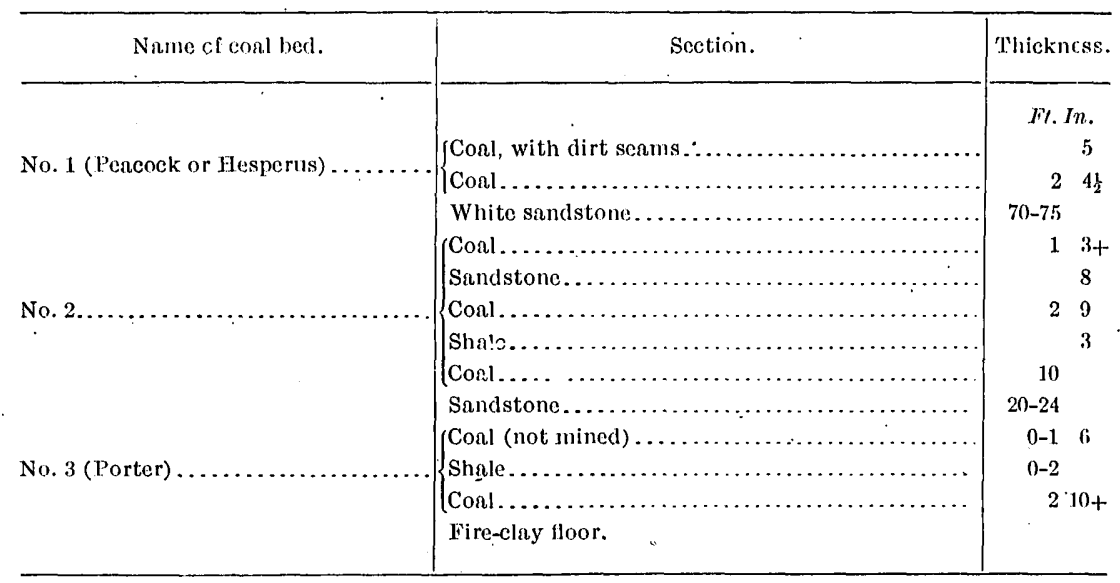


At present work is carried on almost exclusively on the No. 3, or Porter bed, but a large amount of coal has been taken from coal bed No. 2 and a new mine is being opened on the upper or No. 1 bed. At this mine the coal is screened into three grades-lump, nut, and slack. The Jump and nut are sold for domestic and steam purposes and the slack, amounting to about one-quarter of the output, is sold to the smelter company for the manufacture of coke. The coke is of fair quality, and it is claimed to equal, if not excel, any other coke produced in Colorado.

A sample of this coal was taken last summer in connection with the coal-testing work at St. Louis. The sample was obtained by making a cut across a working face of the coal, including all of the coal from roof to floor. The sample was crushed and quartered down to convenient size and sent in a sealed can to the chemical laboratory at St. Louis, where it was analyzed with the result shown in analysis No. 11 on page 258 . According to this analysis the coal is of a particularly high grade, being low in sulphur, moisture, and ash, and high in fixed carbon.

The coal beds of this group are also worked at Hesperus, 10 miles from Durango, in the western part of the district. In this locality there are three beds which seem to correspond to those at Porter and Durango. Two mines have been opened, the Hesperus mine, by the Porter Fuel Company, and the Ute mine, by the Ute Coal Company. Both of these mines are in the lowest coal bed, which is believed to be the same as the Porter bed. The only mine in operation is the Hesperus mine, which is situated on the Rio Grande Southern Railroad, and practically all of the output is shipped over this line.

At a geologic horizon about 2,500 feet above the Mesaverde formation occurs a group of coal beds near the middle of the Laramie (?) formation. The coal of this group is of poorer quality than the Porter coal just described, but on account of the thickness of the beds it may prove to be of considerable value.

The best exposure of this coal is about 3 miles south of Durango, at Carbon Junction, formerly known as Carbonero, and from this place the coal is usually known as the Carbonero coal. It was once mined here, and a partial section at the now abandoned mine is as follows:

Section of Carbonero coal bed near Carbon Junction, $2 \frac{1}{2}$ miles south of Durango, Colo.

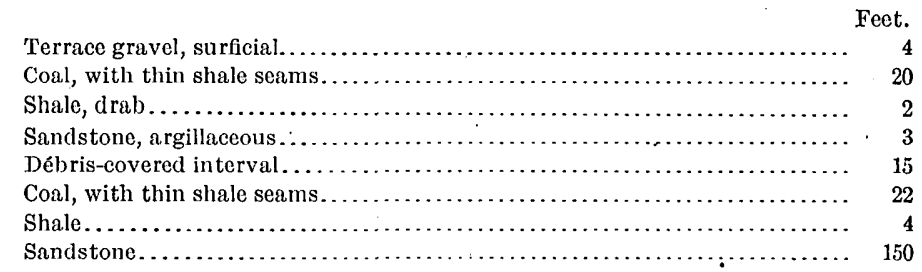

The same coal bed was formerly worked at the La Plata mine, east of Carbon Junction, where it has a thickness and section similar to those on Animas River. When in operation, this mine was connected with the Denver and Rio Grande Railroad by a spur from Arboles.

\section{LOS PINOS RIVER DISTRICT.}

The Los Pinos River district lies east of the Durango district and extends from Florida River eastward across Los Pinos River, Piedra River, and Rio Nutria. Like the Durango district, it lies mostly in the foothills of the San Juan Mountains, where they give way to the plateau country on the south. It contains both Mesaverde and Laramie (?) coal of good quality, but, having no railroad facilities, the mines are small and the output is limited to local demands. The coal beds of the Mesaverde formation extend eastward from Durango across Florida River. Where they cross the Florida, a coal bed of this group has been opened at the Perkins \& Rockwood mine, showing the following section: 
Section of coal bed at the Perkins \& Rockwood mine, $7 \frac{1}{2}$ miles northeast of Durango, Colo.

Name of coal bed.

In early days this coal was coked and the product was hauled to Durango for smelting purposes. Coal of a similar quality and thickness is reported to occur in the Mesaverde formation near Pagosa Springs, on Rio Nutria, but between Florida River and the Monero district no workable coal was observed in this formation.

The Larnmie (?) coal group is much more extensively distributed, exposed, and worked in this district than the Mesaverde, and it usually includes two or more beds. Slopes have been driven in on one of these beds mear Florida River, about 1 mile south of the Perkins \& Rockwood mine, and the following section is exposed:

Section of coal bed at old mines $7 \frac{1}{2}$ miles northeast of Durango, Colo.

Sandstone.

Ft. In.

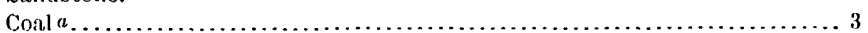

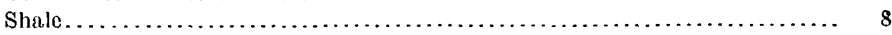

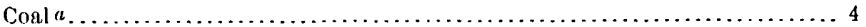

Sandstone.

East of this point the coal beds of this group make only a slight showing for a number of miles. Owing to the scarcity of exposures, it is difficult to determine their exact condition, but they are probably of workable thickness. An opening on the head of Texas Creek, 9 miles northwest of Bayfield, shows the following section:

Section of coal bed in Carleton's coal mine, 9 miles northwest of Bayfield, Colo.

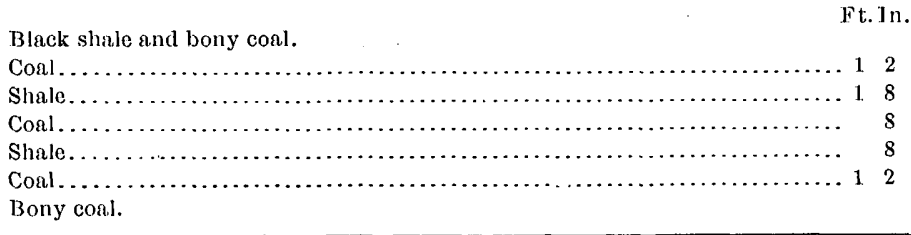

a The quality of this coal is unknown, but according to report it has been tested and found to be "semicoking." 
Farther southeast the coal beds of this group are of workable proportions, as shown by the following section near Beaver Creek, a tributary of Los Pinos River:

Section of coal bed in sec. $17, T .35 \mathrm{~N} ., R .6 \mathrm{~W} .13$ miles north-northwest of J.W Love's ranch, near Beaver Creek, Colorado.

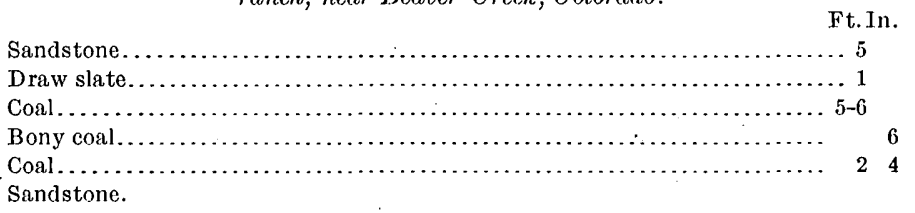

On the head of Beaver Creek, where this bed is worked in the Black, Wheeler, and other mines, its section is substantially as follows:

Section of coal bed in Wheeter mine, at head of Beaver Creek, Colorado.

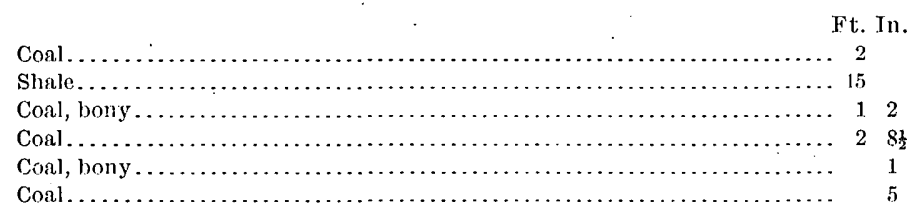

$\Lambda$ sample was taken at this mine for chemical analysis by making a cut from roof to floor across the face of the coal, exclusive of the bony coal parting 1 inch in thickness. This sample, consisting of about 25 pounds of coal, was crushed to about one-half inch size and quartered down until a quart sample was obtained. This was sealed air-tight in a galvanized-iron can and sent to the coal-testing plant at St. Louis for analysis. The result is given in analysis No. 1, on page 258 . This shows the sample to be a good grade of bituminous coal, with a fairly low percentage of moisture and sulphur, but a high percentage of ash. The great amount of ash is the principal defect in this coal, which otherwise seems to be a steaming coal of good quality.

South of Beaver Creek the sandstones associated with the Laramie (?) coal group form a line of hogbacks trending nearly south to the head of Yellowjacket Creek, a tributary of Piedra River. The coal has been opened at several places along this line, but only a few of these prospects were visited. An opening on the Glenn ranch, on Yellowjacket Creek, shows a section of about 100 feet in which there are three coal beds, measuring, in ascending order, 6 feet, 4 feet, and 13 feet in thickness. Five miles farther south, near the Big Bend of the creek, the coal has been-well prospected, and it is reported to be changed locally to anthracite and to contain natural coke.

Down the Piedra from the mouth of Yellowjacket Creek to Rio Nutria and extending a few miles up the latter stream the outcrops of coal are more or less continuous, and since the rocks are only slightly inclined, the coal beds underlie a considerable area between the Piedra and Nutria. At a number of points in this region the coal has lost much of its value by fire, which locally has burned out some beds and deteriorated others.

\section{MONTEZUMA MOUNTAIN DISTRICT.}

The Montezuma Mountain district lies to the east of the one just described and extends from west of Gato Creek and the Rio Grande, Pagosa and Northern Railroad southeastward across San Juan River to the New Mexico line. The Laramie (?) alone is coal bearing in this district, or at least this is the only formation in which workable coal was found The coal has been mined by whites and Indians in the hills west of Gato Creek and in the mesa contiguous to Archuleta Mountain, east of San Juan River. Near the latter place the principal coal bed caps Montezuma Mountain, and for that reason is currently known as the "Montezuma 11-foot vein." Prospects have been opened on San Juan and Navajo rivers several miles above Juanita, but the only point of commercial production at present 
is the Talian mine, situated on Indian land 4 miles north of Pagosa Junction, on the Rio Grande, Pagosa and Northern Railroad. At this mine the dip of the rocks is $26^{\circ}$, and a section of the coal beds exposed is as follows:

Section of coal beds in Talian mine, 5 miles north of Pagosa. Junction, Colo.

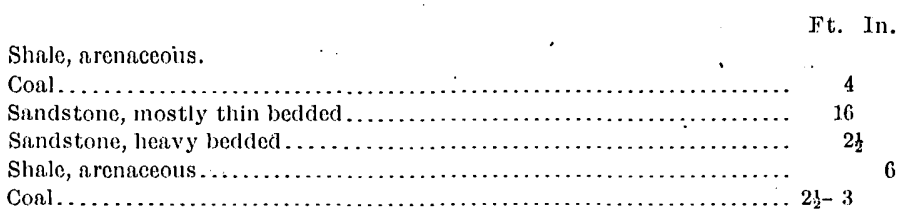

'ilhe coal is used principally for steam and domestic purposes.

At the Archuleta tunnel (abandoned), 7 miles northeast of Junnita, the coal was mined some years ago and used in drilling for oil at the head of Montezuma and Coyote creeks. The coal bed consists of $10+$ feet of good coal, including two shale partings varying from 1 to 2 inches in thickness. The floor and roof are shale, and the dip of the beds is to the southwest at the angle of about $5^{\circ}$.

\section{MONERO DISTRICT.}

The Monero district extends from Navajo River, at the Colorado line, southward along the Continental Divide to Horse Lake, New Mexico. It lies in the plateau proper and apart from the foothills of the San Juan Mountains, from which it is separated by the Chama Valley. It is bounded on the enst for the most part by a prominent eastward-facing escarpment several hundred feet high, formed by the upturned edges of the Mesaverde sandstone, which here forms the Continental Divide and is locally known as the "rim rock." It drains to the west by way of Amargo Arroyo into Navajo River.

In this district the coal beds of the Laramie (?) are thin, shaly, and unimportant, but the Mesaverde formation contains two main beds of workable thickness and of about the same quality as the Mesaverde coal in the Durango district. The coal contains much fossil resin, which accelerates its combustion and renders it desirable for domestic use. It is a coking coal, and its chemical composition is shown in analyses Nos. 12 and 13 in the table on page 258 .

The only locality at which mining is done on a commercial scale is Monero, which is located near the center of the district, on the Denver and Rio Grande Railroad. At this place the general dip of the rocks is about $4 \frac{1}{2}^{\circ} \mathrm{W}$, but this is far from regular, as the beds are cut by n number of faults which disturb their dip and continuity.

Three mines have been opened at Monero. The Kutz mine was temporarily shut down at the time it was visited, but considerable coal has been taken from it. The section of the coal beds exposed in this mine is as follows:

Section of coal bedls in Kutz mine, Monero, N. Mex.

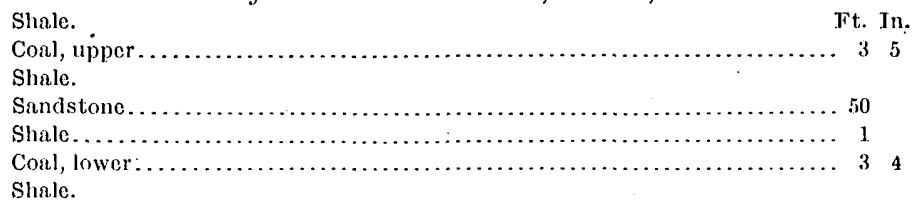

A sample was taken of the upper bed at this mine for chemical inalysis. The material for the sample was obtained by making a cut across the face of the coal from roof to floor, a distance of 3 feet 5 inches, and as there are no partings in the coal the sample contained everything in the bed. This material was pulverized and quartered down at the mine until a quart sample was obtained, and this was sealed air-tight in a galvanized iron can and sent to the laboratory for analysis. The result is shown in analysis No. 12 in the table in page 258 . 
The McBroom mine is working on the upper coal bed and the Monero mine on the lower bed of this group. The main gangway of thelatter is driven down on the slope of the coal for about 1,600 feet. A sample for chemical analysis was taken from this mine in the same manner as from the Kutz mine. The material of the sample was obtained from a cut made across the entire frce of the coal bed $33 \frac{1}{2}$ inches in thickness. The result is shown in analysis No. 13 in the table, on page 258. The analyses of the samples from the two mines are very similar, except in the amount of sulphur and ash. The percentage of sulphur in the Kutz sample is remarkable, and exceeds that in any other sample obtained from this field. Aside from the ash and sulphur there is a great similarity in the composition of the two samples, and they both rank as fairly high grade bituminous coals.

The output of the district is about 40,000 tons per year, three-fourths of which is from the Monero mine. About 15 per cent of the total product is fine coal, which now is wasted for lack of coking facilities. Eighty per cent of the merchantable coal is used by the Denver and Rio Grande Railroad for locomotive coal, 12 per cent goes to the New Mexico Lumber Company, and the remainder is used in home consumption and a limited commercial trade.

Heretofore the coal has sold readily for $\$ 1.50$ per ton, but at present the ruling price is $\$ 1.25$ per ton. The Rio Arriba Coal Company, which operates the Monero mine, estimates the coal now in sight on its ground at 5,000,000 tons, which will enable this mine to continue its present rate of production for considerably more than a century.

At Lumberton the coal has been worked, but only to supply the local demand. The beds dip slightly to the west, but they are more broken by faults than at Monero. The following section was measured in a gulch 1 mile southeast of Lumberton:

Section of coal bed 1 mile southeast of Lumberton, N. Mex., in sec. 3, T. 31 N., R. $1 \mathrm{~W}$.

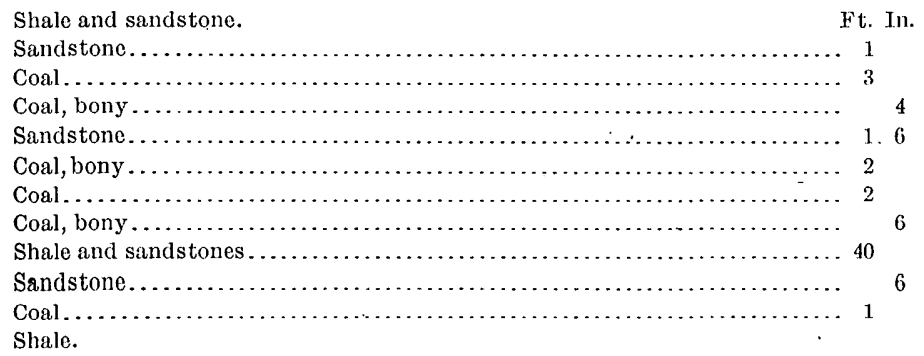

The coal beds seem to grow thin south of Monero, as shown by the following section which was measured near Horse Lake:

Section of coal bed in sec. 1, T. 30 N., R. 1 E., about 8 miles southeast of Monero, N. Mex.

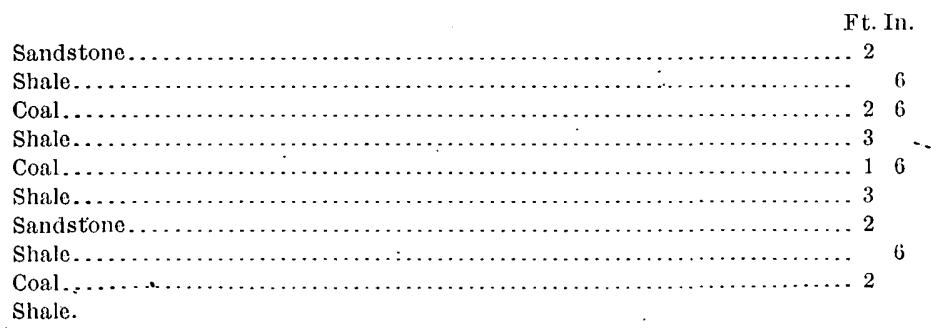

STINKING LAKE DISTRICT.

The Stinking Lake district lies west of Chama River and Elvado, and extends from Boulder Lake southward beyond Stinking Lake. It drains east into Chama River. No mines have been opened in this district. Some good coal is present, but probably it does not occur over large areas or ip promising quantities. The Mesaverde is the coal-bearing 
formation, and the hogback formed by its hard beds constitutes the continental divide as at Monero. From the summit of this hogback the dip is gently westward and the rocks pass by low dips under the San Juan basin to the west. The beds are well exposed near the northeast shore of Boulder Lake and the Elvado Railway. In general little is known regarding the coal of this district, but it shows in places in natural exposures, as indicated by the following section, which was measured near Boulder Lake:

Section of coal bed near the railload, one-fourth mile northeast of Boulder Lake, New M.exico, in sec. $18, T .29 \mathrm{~N} ., \mathrm{R} .1 \mathrm{~W}$.

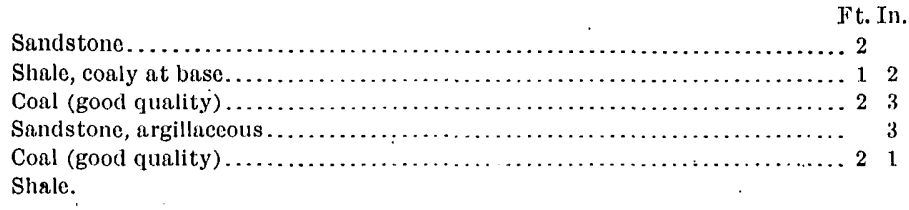

At Stinking Lake the coal outcrops at intervals along the east shore, which is several miles in extent. Although it is easily accessible and the beds aggregate 10 feet in thickness, the coal is so broken by partings as to be of little value. The section is as follows:

\begin{tabular}{|c|c|c|}
\hline \multirow{2}{*}{\multicolumn{3}{|c|}{ 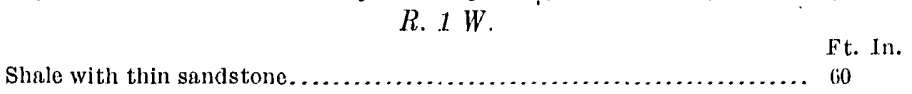 }} \\
\hline & & \\
\hline 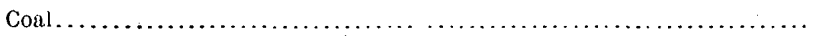 & & \\
\hline Shale, black............. & & 2 \\
\hline Coal.................. & 1 & \\
\hline Shale, black............. & 4 & \\
\hline Coal .................... & 1. & 3 \\
\hline Shate, black...................... & 3 & \\
\hline Coal.............................. & 1 & \\
\hline Shale, black......................... & 35 & \\
\hline Shale, a renaceous ................ & & 3 \\
\hline 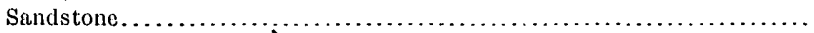 & 1. & \\
\hline Shale, arenaceous................ & $15^{\circ}$ & \\
\hline Sandstone, argillaccous............ & 10 & \\
\hline Shale, black. . . . . . . . . . . . . . . & 18 & \\
\hline 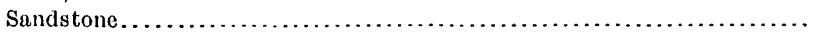 & 2 & \\
\hline Coal................................ & 1. & \\
\hline Shale......................... & 1 & 6 \\
\hline Sandstone $\ldots \ldots \ldots \ldots \ldots \ldots \ldots \ldots$ & & 4 \\
\hline Shale, black...................... & 2 & 6 \\
\hline Coal........................... & 1. & $s$ \\
\hline Shale............................. & 1. & \\
\hline Sandstone, ferruginous............. & & \\
\hline 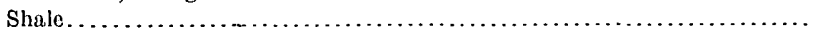 & & \\
\hline 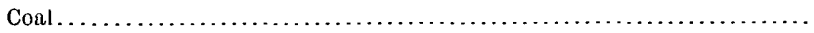 & 1 & \\
\hline Shale............................... & 10 & \\
\hline Cons.............................. & & 10 \\
\hline 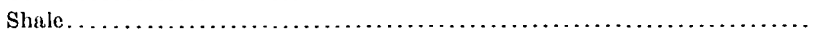 & & 2 \\
\hline Conl.......................... & 1 & \\
\hline 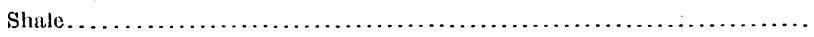 & & \\
\hline Sindstone....................... & 20 & \\
\hline & 195 & \\
\hline
\end{tabular}

\section{GALLINA DISTRICT.}

The Gallina district lies south of the one last described, and extends from 12 miles north of Gallina to the divide between Gallina and Puerco rivers, a distance of 1.5 miles, and flanks Gallina Mountain on the west. No mining has been done in the district, but the conl appears to be of good quality and is workable, and with the installation of transportation facilities-may become an important factor in the fuel supply of the Southwest. 
The workable beds occur in the Mesaverde formation, which is exposed in the lower dip slopes of a prominent hogback, in which the beds are upturned at angles varying from $20^{\circ}$ to $40^{\circ}$.

In the north end of the field, near the Elvado-Gallina road, a natural outcrop shows the following section of the coal beds:

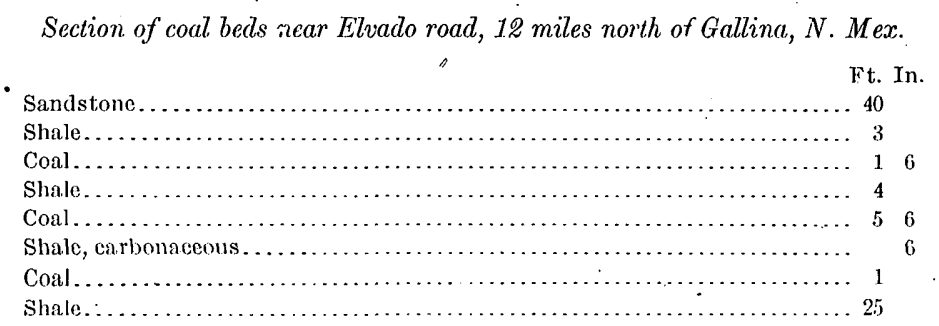

Three miles west of Gallina the same rocks are exposed, and the following section was measured:

Section of coal beds 3 miles west of Gallina, N. Mex.

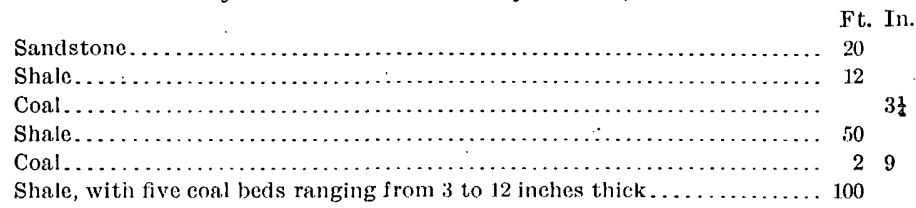

As the coal beds incline to the west from the hogback, wlich limits the field on the east, they pass beneath the surface of an open valley or sage-brush flat nearly 100 miles in areal extent, and since the dip generally decreases toward the center of the basin the coal beds can probably be reached at a moderate depth by shafting, an important point in the prospective economic development of the district. An ample supply of timber suitable for mining purposes may be found on Gallina Mountain near by, and thus all natural conditions are favorable for economic mining.

All the coal beds so far described in this district occur in the Mesaverde formation, but the Laramie (?) also contains coal, as shown by the outcrop of a bed of good coal 12 to 15 inches thick 7 miles north of Gallina. This is noteworthy as being the first good coal found in the Laramie (?) formation south of Navajo River.

\section{NACIMIENTO DISTRICT.}

The Nacimiento district flanks the west base of the Sierra Nacimiento, and extends from north of Lajara nearly to San Miguel, below Senorita, a distance of about 16 miles. In general the coal-bearing rocks dip steeply to the west, but in come localities they are overturned and dip in the opposite direction. Between Lajara and Cuba they are exposed only in the heads of deep canyons or cirques, cut through the overlying Tertiary and the talus and wash along the base of the mountains.

Near the site of the old Copper City smelter, however, 3 miles east of Cuba and 2 miles north-northwest of Senorita, the hogback formed by the Mesaverde is exposed and the following section was measured:

Section of coal bed near site of old Copper City smelter, 2 miles north-northwest of Senorita, N. Mex.

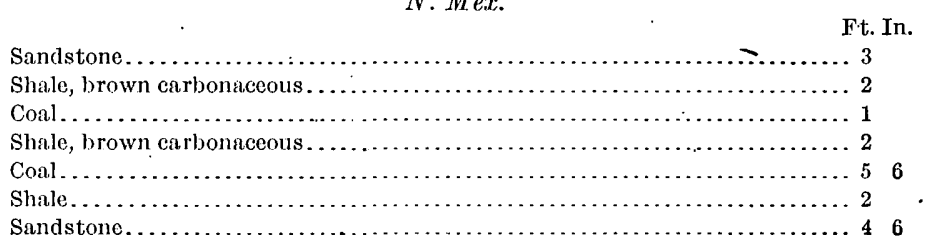


The conl in this bed is of good quality and has been mined for local use. The rocks are overturned and dip east, toward the mountain, at an angle of about $70^{\circ}$.

The same coal bed has been opened by the roadside near Senorita, 2 miles south of the above-mentioned locality, and mined by the Juratrias and other copper companies. The coal was used for steaming and smelting, as well as for domestic purposes. It is of good quality and is reported to have given general satisfaction. The coal bed is about 6 feet thick and inclines steeply to the east at an angle of about $70^{\circ}$, the measures being overtunned, as at Copper City.

South of Senorita the coal outcrops at intervals for a distance of several miles, nearly to the place where the Mesaverde formation, stịll upturned and on edge, disappears below overlying younger formations. Beyond this place the formation seems to extend a long distance to the south and probably carries the coal beds that are reported west of Albuquerque. About a mile north of the place, where the Mesaverde formation disappears, it is unconformably in contact on the west with coal-bearing rocks, which lie nearly flat and are younger than the Mesaverde and form the Chico Arroyo district, described below. The contact between these two formations is due to faulting.

\section{CHICO ARROYO DISTRICT.}

The Chico Arroyo district extends from the western base of the Sierra Nacimiento, between Senorita and San Miguel, southwestward nearly to San Mateo and Mount Taylor, $\leadsto$ distance of nearly 60 miles.

The coal beds are associated with clay, carbonaceous shale, and sandstone, which aggregate a thickness of from 2,000 to 3,000 feet, and are regarded as a great conl-bearing group; but, as previously noted, they are faulted in contact with the Mesaverde formation on the cast, and so it was impossible during this reconnaissance to determine their exact relations and geologic horizon. Some invertebrate fossils were found in them, however, which indicate that they belong above the Mesaverde formation, in the upper part of the Montana. Hence, on account of its relative position in the series, the group is here designated the upper conl group of the Montann formation.

Throughout the district the beds in general dip about $3^{\circ}$ in a direction slightly west of north. The conls are exposed mainly in the scarp formed by the southeastern edges of the rocks along Rio Puerco and the head of Torreones Arroyo and underlie the Chacra Mesa and the lava-capped plateau of the Sierra Chivato. The following sections were measured at separate localities well distributed throughout the district and give a fair idea of the character of the conl beds of this group:

Section of coal bed in the mesa west of Rio Puerco, 15 miles north-northeast of Cabezon, N. Mex.

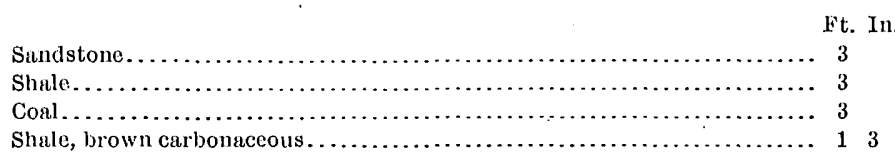

Section of coul bed 3 miles above mouth of Arroyo de los Torreones, 10 miles west-northwest of Cabezon, N. Mex.

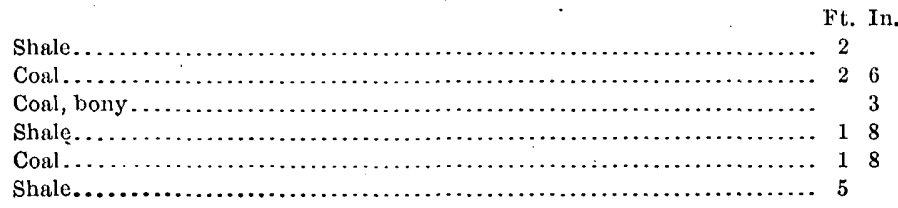


Section of coal beds in the mesa 1 mile north of Chico Arroyo, about 16 miles west of Cabezon, N. Mex.

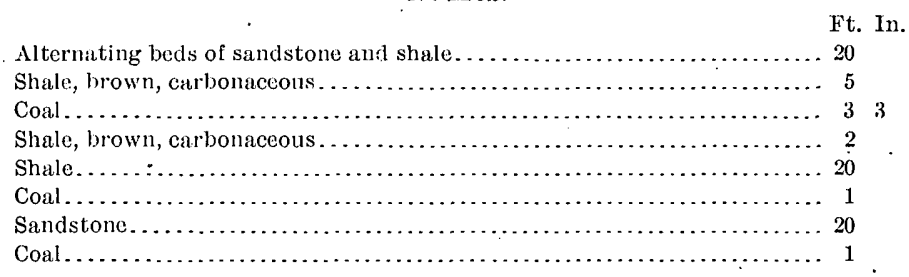

Section of coal beds three-fourths of a mile north of the Cabezon-San Mateo road, 23 miles from Cabezon, N. Mex.

\begin{tabular}{|c|c|}
\hline \multicolumn{2}{|r|}{ Ft. In. } \\
\hline Shale, arenaceous. & 5 \\
\hline Coal.............. & 1 \\
\hline 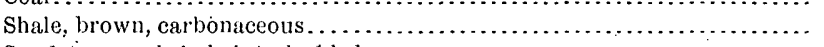 & 6 \\
\hline 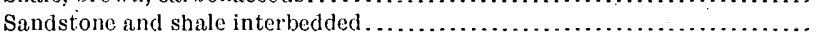 & 8 \\
\hline 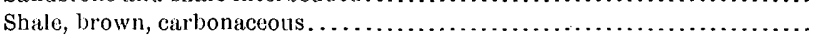 & 2 \\
\hline Coal $. \ldots \ldots \ldots, \ldots, \ldots, \ldots, \ldots$ & 29 \\
\hline
\end{tabular}

Section of coal bed 5 miles north of Alesna Peak, New Mexico.

Shale, brown, curbonaceous.

Ft. In.

Coal.

Section of coal bed in arroyo 21 miles north of the Cabezon-San Mateo road and 5 miles westsouthwest of Alesna Peak, New Mexico.

Shale.

Ft.

Coal, with thin, bony partings near top and middle.

Shale.

No development has been undertaken in this district. The coal is a good grade of black lignite and in appearance compares favorably with the Carbonero coal and with that of Gallup and Fruitland, to be described later. It is probably of workable thickness throughout an area of at least 300 square miles.

\section{HOSTA BU'TYE DISTRICT.}

The Hosta Butte district extends north of west from San Mateo and Mount Taylor across the continental divide nearly to Gallup, a distance of about 60 miles. It lies about 12 miles north of the Atchison, Topeka and Santa Fe Railway, and contains three groups of coalbearing rocks, upper, middle, and lower.

The upper coal group was observed only in the northwestern part of the district, in the southeast corner of the Navajo Indian Reservation, where it has an extent of about 30 miles in an east-west direction. From the similarity of its beds it is correlated with the upper coal group of the Chico Arroyo district, which has been referred to the upper part of the Montana, and with which the beds probably connect beneath the plain along the north border of the Hosta Butte district. Owing to scarcity of outcrops, however, th is connection has not been traced. The beds of this district also seem to connect with those at Gallup, to be described later, and it is also probable that they bear the coal reported to occur 30 to 40 miles north of the Hosta Butte district out in the basin, at Stony Butte and beyond Rio Chaco.

The middle and lower coal groups enter the Hosta Butte district from the direction of Mount Taylor and, after extending north westward across the district, curve southward and form the hogback, which crosses the railroad 3 miles east of Gallup. Their geologic age is not definitely determined, but from the evidence of a few fossils collected in each of them it is probable that the middle group represents the lower part of the Montana formation and that the lower group represents a part of the Colorado formation. 
In the center of the district, near Hosta Butte, the vertical interval between the groups is about 500 or 600 feet. In general, the dip of the rocks is to the north and the coal beds are exposed in southward-facing escarpments, but where the rocks are sharply upturned, in the hogback east of Gallup, they do not seem to carry coal in workable amount.

The coals of this district have been little prospected, but they show in natural outcrop at many localities. The better-known exposures lie along the Grant-Farmington road, the Thoreau-Seven Lakes road, the Devils Pass trail, near Lake Mariana, and at Hosta Butte, where the rocks are raised into a low dome.

So far as known, the lower coal group contains only one workabje bed, which, as shown in the following section, is about $2 \frac{1}{2}$ feet in thickness:

Section of coal bed of lower coal group in the mesa 15 miles north-northeast of Thoreau, N. Mex.

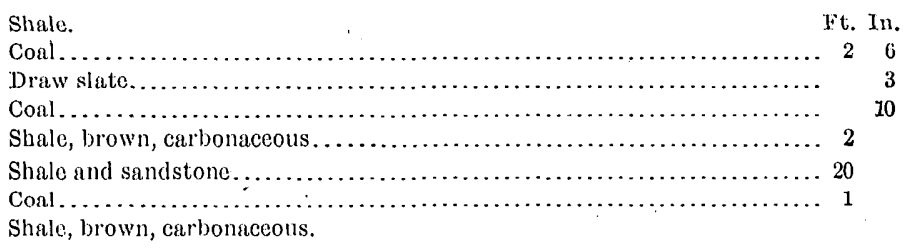

A similar section is exposed 15 miles north of Bluewater, at the J. E. 'Tiejen prospect, on a coal bed t'ant is supposed to be the same as the one noted above.

Coal is more abundant in the middle group than in the lower. The former contains a vast amount of coal, as shown by the areal distribution of the measures on the map (P.I. VII) and the coal beds given in the following sections:

Section of coal beils near the Farmington road, 25 miles west of San Mateo, N. Mex.

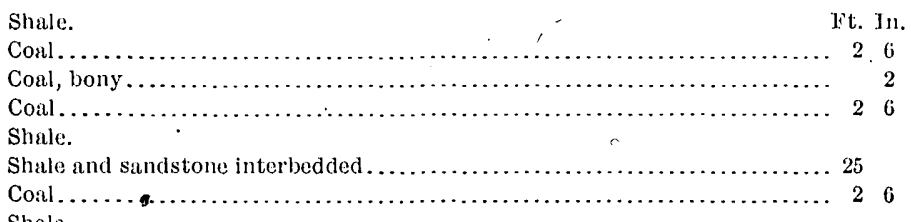

Section of coal beds in Devils Pass, 4 miles east of Hosta Butte, N. Mex.

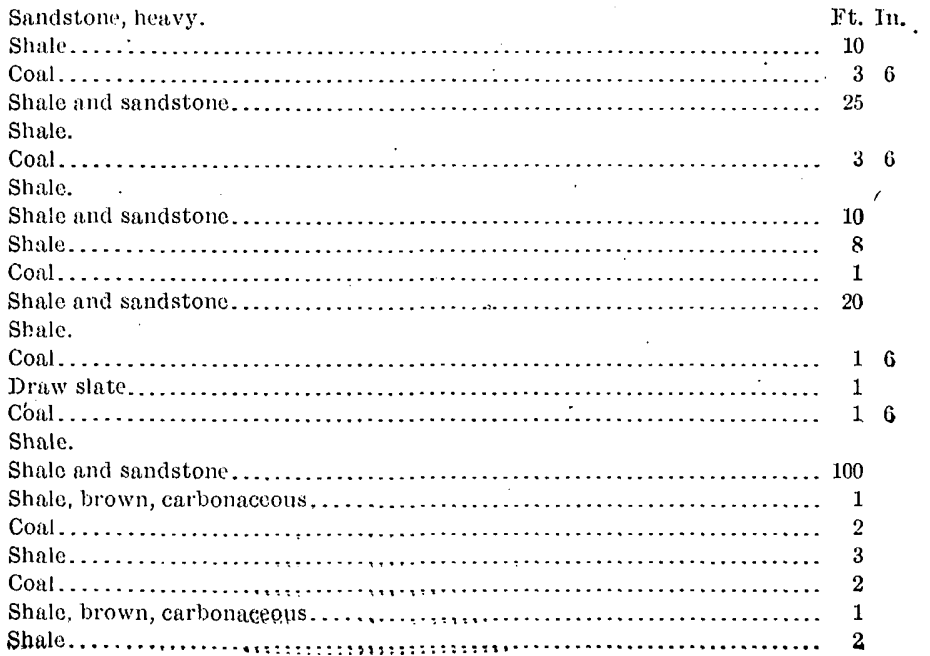




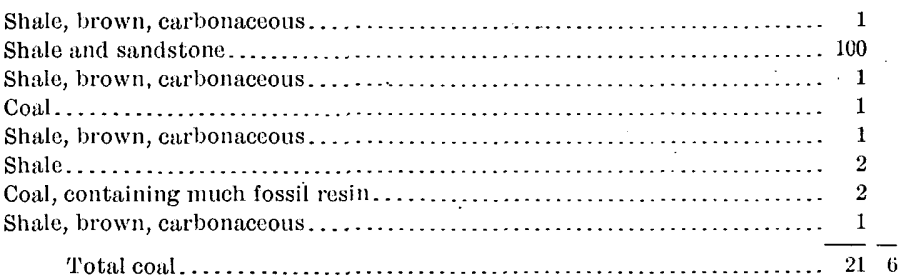

Section of coal bed at Tiejen prospect, on Seven Lałes road. 17 miles northeast of Thoreau, N. Mex.

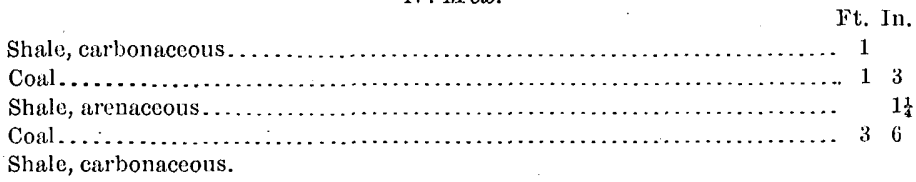

The coal is a good black lignite and contains much fossil resin, resembling in th.s respect the Monero coal. A sample was taken from the Tiejen prospect for analysis. The material was secured by making a cut across the face of the coal, exclusive of the parting $1 \frac{1}{4}$ inches in thickness. The coal was crushed and quartered down to a quart sample, which was sealed air-tight in a galvanized-iron can and sent to the laboratory at St. Louis. The result is shown in analysis No. 10 of the table on page 258. With the exception of the heavy percentage of water, this analysis compares favorably with the analyses of other coals of the field.

\section{GALLUP DISTRICT.}

The Gallup district extends from the hogback 3 miles east of Gallup westward beyond Defiance, a distance of about 12 miles. It is crossed by the Atchison, Topeka and Santa Fe Railway and is the oldest, best known, and most productive district in the field. The coul-bearing group of rocks of this district, so prominent around Gallup, lies higher in the series than the groups that form the hogback east of Gallup. Its geological horizon has not been well determined, but from some fossil plants found at the Weaver mine, north of Gallup, it is referred to the upper part of the Montana formation and is probably the same as the upper coal groups of the Chico Arroyo and Hosta Butte districts. It is divided into upper and lower subgroups, which are separated by about 500 feet of sandstone and sandy shale. In the immediate vicinity of Gallup the dips are from $2^{\circ}$ to $15^{\circ} \mathrm{NW}$., but they vary in direction, as the rocks are gently folded. In general this part of the field has the structure of a syncline with the rocks dipping toward the center from each side. The synclinal axis is known to extend south of Gallup into the Zuñi Plateau, but this area was not examined during the present reconnaissance. The upper subgroup of coal-bearing beds is about 100 feet in thickness and, as shown by the following section, based in part on data obtained from the American Fuel Company at its Gallup and Weaver mines, contains six workable beds of coal:

Section of upper coal subgroup at the Gallup and Weaver mines 3 miles north of Gallup,

Sandstone. N. Mex.

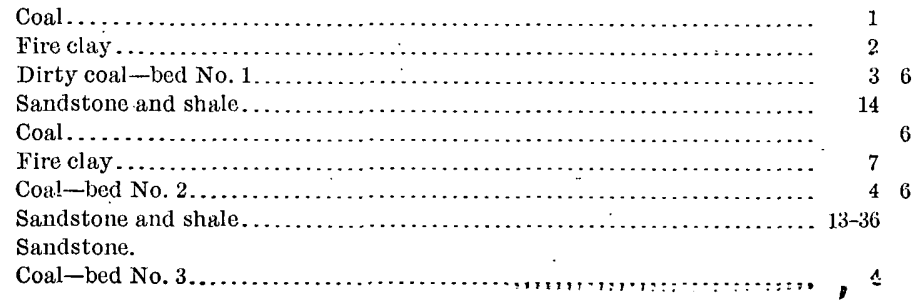




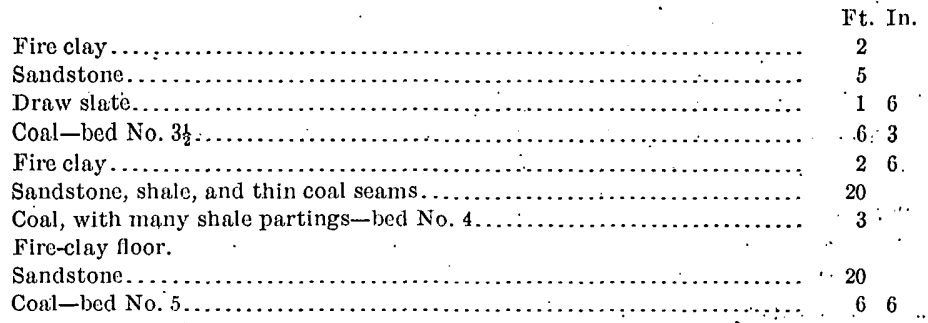

The lower subgroup contains four workable beds, known as the Crown Point, Thatcher, Black Diamond, and Otero. 'The following is a partial section of this subgroup at the Otero mine:

Section of lower coal subgroup at Otero mine, $1 \frac{1}{2}$ miles east of Gallup, N. Mex.

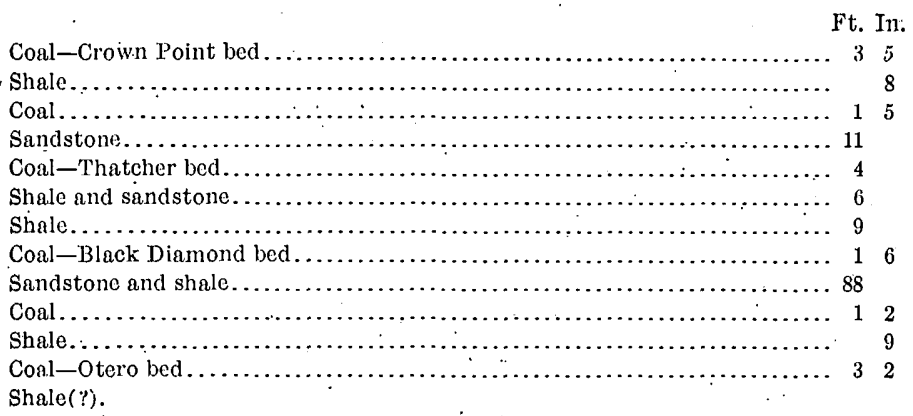

Of the dozen mines in the district, those now producing are the Weaver, Otero, Heaton, Rocky Clift, Union, and Clark. The Weaver mine is the most important. Its record output is 2,250 tons per day. Its gangways extend 3,000 feet in, and diamond-drill prospects 4,000 feet beyond the working faces show that the coal beds continue at least to that distance without perceptible change, either in thickness or quality of coal.

The total output of the district in 1903 was 569,362 short tons and in 1904, 441,865 short tons. The decrease in the output for 1904 is due in large measure to the introduction of fuel oil as a substitute for coal on the locomotives of the Atchison, Topeka and Santa Fe Railway. The market value of the coal at the mines is $\$ 1.32$ per ton. The number of men employed in the district is 700 .

The coal of this district is a black shining lignite which approaches bituminous coal closely. in composition. Its principal defect is that it crumbles on exposure to the air and is so light that when used in locomotives a large proportion of it is carried out of the stack. Samples for chemical analysis were taken at the Weaver, Otero, and Clark mines. Those representing the Weaver and Otero mines were secured in connection with coal tests that were made in 1904 at the Geological Survey coal-testing plant at St. Louis.

In the Weaver mine the samples were obtained from beds No. 3 and No. $3 \frac{1}{2}$ by cuts across the face of the coal from roof to floor, including everything, as the beds are free from partings of any kind. These large samples were pulverized and quartered down to quart size and sent in sealed cans to the laboratory at St. Louis. Analysis No. 5, on page 258, represents the sample from bed No. $3 \frac{1}{2}$, and analys:s No. 6 that from bed No. 3 .

Similar samples were taken from the Otero mine, every precaution being taken to insure their representative character. Analysis No. 7, on page 258, represents the sample from the Crown Point bed, No. 8 that from the Otero bed, and No. 9 that from the Thatcher bed. The sample from the Clark mine was obtained during the course of the present work. It was obtained by making $a$ cut across the working face of the coal, $8 \frac{1}{2}$ feet in thickness, and included everything except two partings 1 inch and 3 inches thick. This sample was treated in the usual manner and its character is shown by analysis No. 4, on page 258 .

Bull. 285-06-17 


\section{FRUITLAND DISTRICT.}

The Fruitland district lies in the northwestern part of the field and extends from near Bennetts Peak on the south to the State line above Pendleton, on La Plata River, a distance of 50 miles. The limits thus defined are not marked by natural boundaries, but s:mply show the extent of the work of this party. To the northeast the coal-bearing beds are doubtless continuous with those of the Durango district, but they were not followed through. To the south little is known regarding the extent of the outcrop. It seems probable that the beds in the Fruitland district extend to Gallup, but if so they are probably largely concealed under the Choiskai Mesa.

The coal of this district is best known in the vicinity of Fruitland, where it is crossed by San Juan River, and at Pendleton, on La Plata River. Both the Mesaverde and the Laramie(?) coal groups are present, but the former has not produced coal, though it probably carries beds of workable thickness. The rocks of this group are exposed in the hogback which crosses San Juan River at Jewett and Chaco River 4 miles to the south. At the latter point they dip about $40^{\circ} \mathrm{E}$. and contain two coal beds which measure 3 feet and 1 foot, respectively, in thickness and which are separated by a shale interval of about 25 feet. In the northern part of the district, a few miles west of Rio La Plata, the coal is reported to occur in three beds, 6 feet, $1 \frac{1}{2}$ feet, and 5 feet thick. Some of it appears to be of excellent quality and resembles the peacock coal of Durango.

The Laramie(?) rocks, which occur about 2,000 feet above the Mesaverde formation, flank the Jewett hogback on the east. From this line of outcrop they extend to the east beneath the mesa in a nearly horizontal attitude. They consist of sandstone, shale, and coal, as described in the Durango district. Some of the coal beds are remarkably thick, but for lack of ra:lroad facilities the production is small, not exceeding the local demand.

At Cottonwood Arroyo and along the Chaco east of the hogback the coal crops out in the escarpment near the surface of the mesa, but at Fruitland the northeasterly dip carries it down nearly to San Juan River, in whose bluffs it is exposed on both sides of the valley.

The most important mines at Fruitland are the Hebrum and the Young, favorably located on the public highway $1 \frac{1}{2}$ miles northwest of the village. The Young mine is the only one now in operation. It has furnished practically all of the coal used by Fruitland, Jewett, Shiprock, Farmington, and the surrounding country for a number of years. It has two gangways about 100 feet apart, trending N. $30^{\circ} \mathrm{W}$., wh:le the strata dip to the northeast. The total thickness of the coal beds is about 16 feet, the section being as follows:

Section of coal bed at Young mine, $1 \frac{1}{2}$ miles northwest of Fruitland, N. Mex.

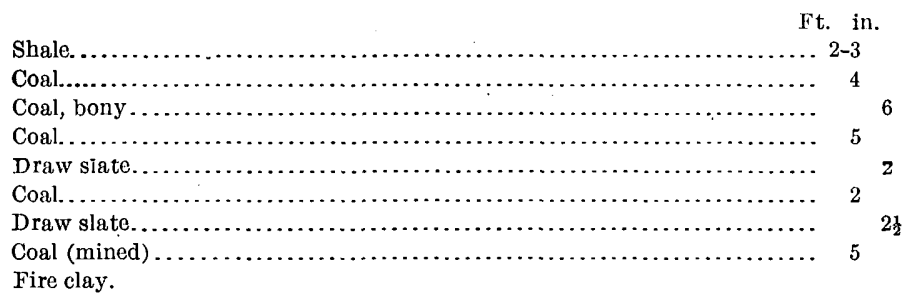

Only the lower 5 -foot bed is now worked. A sample of this bed was taken for chemical analysis. It was obtained by making a cut from roof to floor, including all of the coal worked. This was crushed and quartered down to convenient size and sent in a sealed can to the chemical laboratory. The result, as shown in analysis No. 3 on page 258 , is approximately the same as the analyses of the Gallup coal.

At the Bruce mine, $3 \frac{1}{2}$ miles northwest of Fruitland on the Jewett-Durango road, the coal bed is 23 feet in thickness, and is practically all good coal. Recently this mine has been 
acquired by the Southern Pacific Company, which is making surveys for a railroad line through this part of the field.

Including the Bruce mine and surrounding prospects, the workable coal beds at Fruitland seem to underlie an area of not less than 30 square miles.

In the northeastern part of the district coal has been mined at a number of localities near the Colorado State line, on La Plata River and McDermott Arroyo, where it occurs in a single bed 35 feet thick. One of the principal producers at the present time is the Jones mine, $1 \frac{1}{2}$ miles northwest of Pendleton. At this mine the strata incline about $25^{\circ}$ southeast, and the following section is exposed:

Section of coal bed at Jones mine, $1 \frac{1}{2}$ miles northwest of Pendleton, N. Mex.

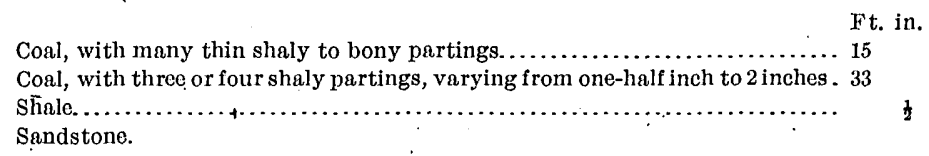

A sample for chemical analysis was taken at this mine in the usual manner. A cut was made across that part of the bed now worked, which consists of 7 feet of clean coal without a parting. The sample was crushed and quartered down to convenient size and sent in a sealed can to the chemical laboratory. The result, as given in analysis No. 2 on page 258, shows that this is of better quality than most of the coal of the district. The moderate amount of moisture indicates that this is a bituminous coal of nearly the same quality as the coal at the head of Beaver Creek, Colorado, as shown in analysis No. 1, but the greater percentage of fixed carbon would seem to indicate that it is of somewhat higher grade. When the percentages of ash in the two samples are considered, it will be seen that the Pendleton coal is very much better than the Beaver Creek coal. 


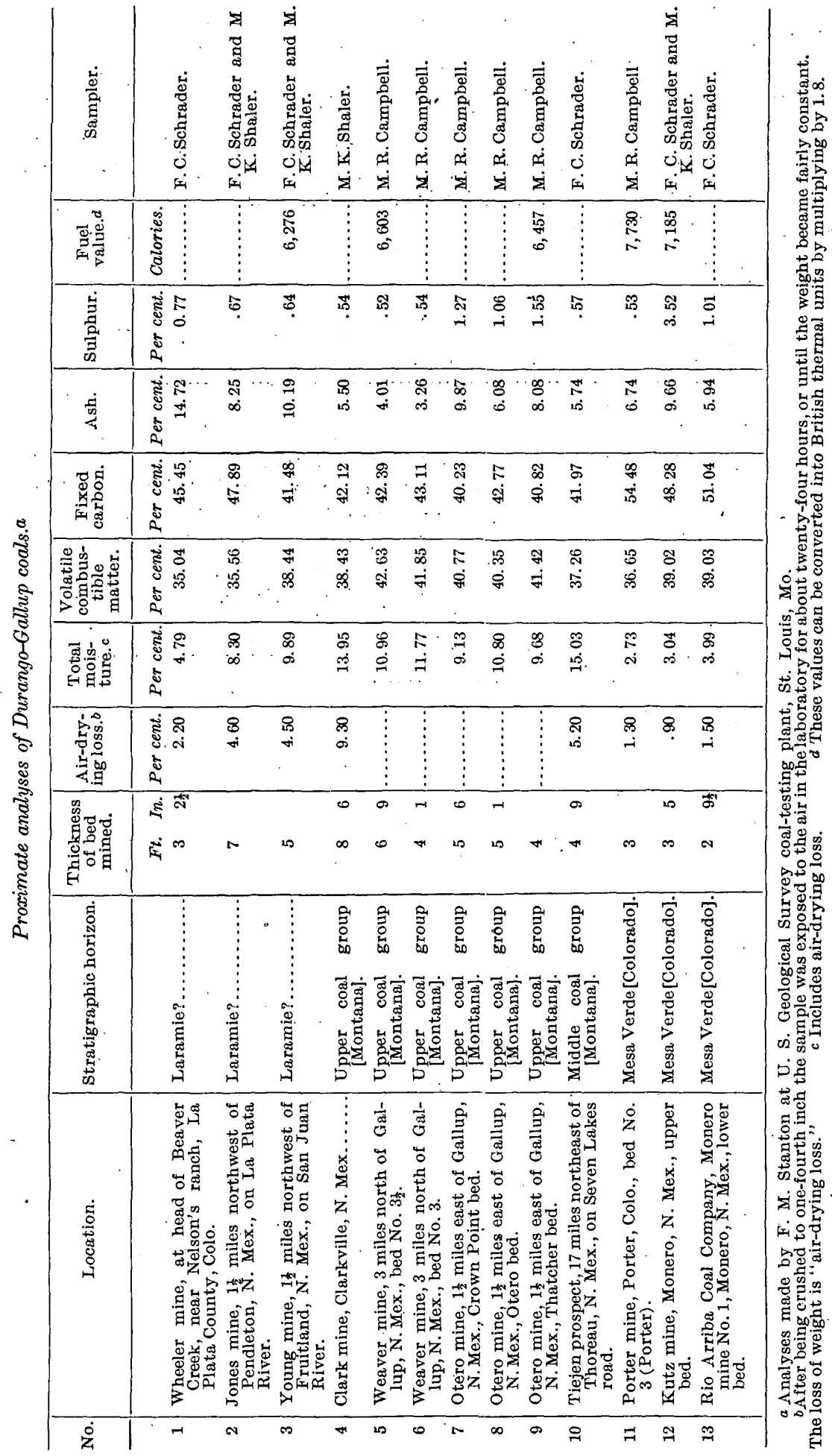




\title{
COAL RESOURCES OF THE KENOVA QUADRANGLE. ${ }^{a}$
}

\author{
By. Wildiam Clifton Phálen. \\ GENERAL DESCRIPTION.
}

Location.-The Kenova quadrangle of the United States Geological Survey embraces an area of 938 square miles, lying in northeastern Kentucky for the most part, but including small portions of Lawrence County, Ohio, and Wayne County, W. Va. (See sketch map, fig. 10.)

This area lies in the western portion of the great Appalachian coal field and just a trifle north of its center as it stretches from north-central Alabama to the southwestern boundary of New York.

Structure.-The Kenova quadrangle is located at the southwest end of the great trough into which the coal-bearing rocks of the Appalachian field are thrown. The axis of this trough extends from the vicinity of Pittsburg, $\mathrm{Pa}$., to the southwest, reaching its maximum depth near central West Virginia. From this point it slowly rises to the southwest, crossing Ohio River a little east of this quadrangle and reaching Big Sandy River near the mouth of Isom Creek, opposite Burgess (Kavanaugh), Ky., and extending in a general southwesterly direction from this point, gradually fading as the southwestern corner of the quadrangle is approached. Toward this axial line the beds are gently inclined, those on the northwestern side dipping to the southeast and those on the opposite side dipping to the northwest.

The dips in this quadrangle do not average more than 50 feet per mile and in some localities the beds are practically flat. In others there is a marked increase in the dip, as in the region south and southeast of Louisa and from Torchlight to Gallup, where the dips range as high as 150 feet, and even more, per mile. This zone of high dips continues southwest of Louisa up Lick Creek and to the west by Adsms post-office as far as the town of Blaine. In the eastern part of this village occur the maximum dips of the region, namely, $11^{\circ}$ in a general northwesterly direction. There are higher dips than this near the village, developed locally, however, with faulting, the extent of which will be duly recorded when the field notes have been worked up in detail. Beyond Blaine the abnormal conditions seem to die out, and about a mile up Hoods Creek and also immediately north and west of the town the dips again become normal. In the region to the north and northwest of Willard there are local dips reaching much above the average.

\section{DESCRIPTIVE GEOLOGY.}

With the exception of a small area of peridotite $b$ near the southwestern border of the quadrangle, in Elliott County, the rocks are entirely sedimentary in origin and belong to the Pennsylvanian series of the Carboniferous system, with the exception of a bare showing of Mississippian (Lower Carboniferous) rocks, the Pleistocene gravel of the river terraces, and the recent unconsolidated sediments $s_{i}$ of the flood plains. The coals were numbered from below upward by the earlier geologists in the Kentucky field and in the following notes refer-

a These notes are intended as a brief préliminary sketch. A more detailed description of the coal resources of the Kenova quadrangle will be published later.

$b$ For a complete description of this interesting occurrence see Diller J. S., Peridotite of lilliott County, Ky.: Bull. U. S. Geol. Survey No. 38, 1887. 
ences to numbers are to those of the Kentucky Geological Survey. $a$ The Pottsville outcrops generally all over the western and southern portions of the quadrangle, running under drainage toward the syncline and forming most or all of the hills along the western and southern edges of the quadrangle. It is prevailingly sandy. This group of rocks comprises all the coals up to and including coal No. 4, besides valuable beds of fire clay. The base of the formation is easily determined, for it rests on top of the Greenbrier (Lower Carboniferous) limestone. Its top is composed of the usually massive Homewood sandstone, which lies some feet above coal No. 4 or rests directly on this coal bed. Certain of the coal beds of this group of rocks are very important on the edges of the basin in the southeastern

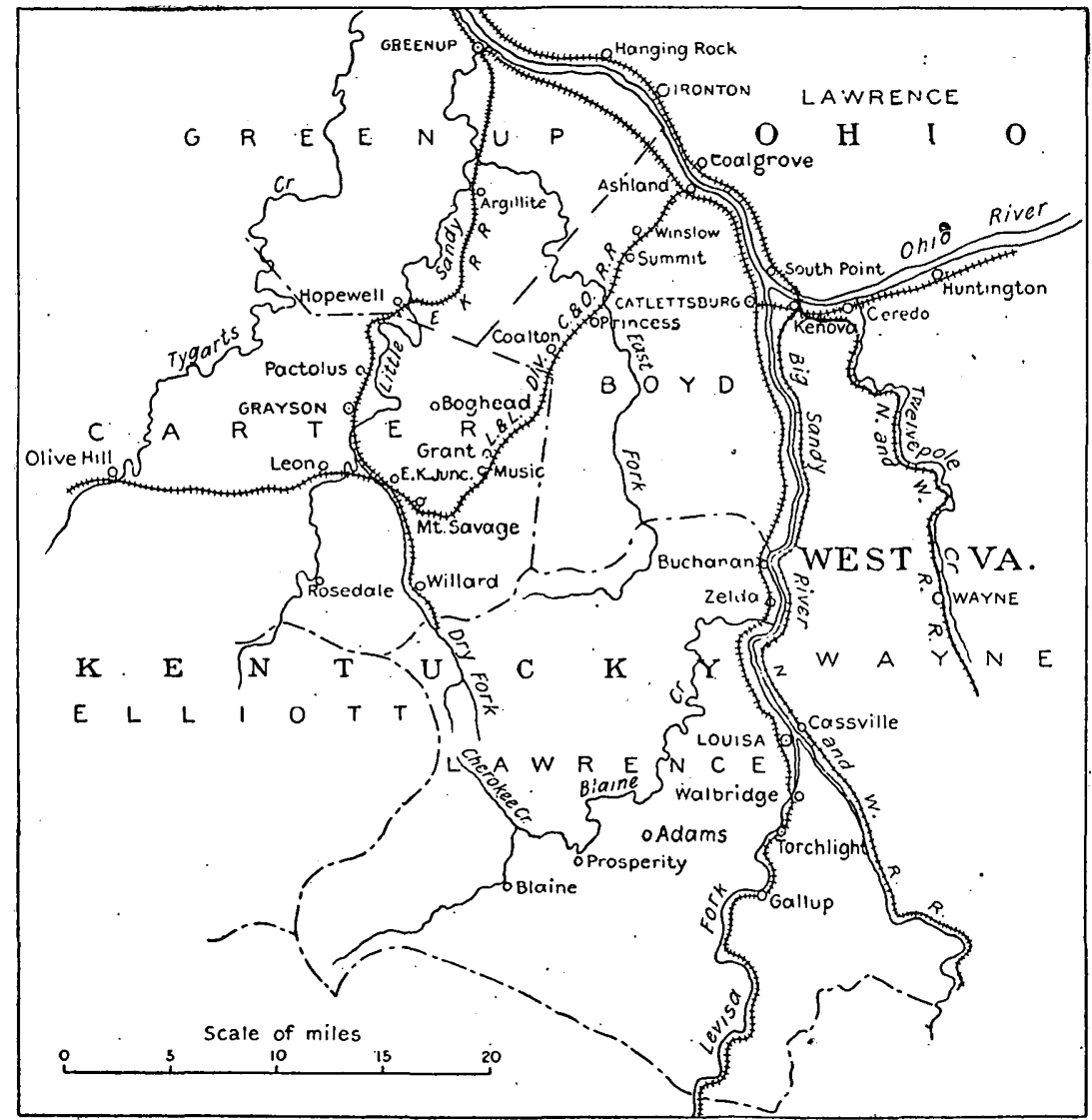

FIG. 10.-Sketch map of northeastern Kentucky and portions of adjacent States.

and western parts of the quadrangle. It is possible that rocks still lower in the Pottsville than the basal Pottsville beds along the western side of the basin occur in the Levisa Fork district, but the evidence on which this statement is based depends on fossil plants collected by Dr. David White, and these have not been studied closely enough up to the present time to warrant a positive statement on this point.

Above these lower sandy formations occurs the group of rocks corresponding to the Allegheny formation of Pennsylvania and containing coals No. 5 to No. 9. It consists of alternating beds of sandstone and shale, with occasional thin beds of limestone, iron ore, and fire clay. This group includes the celebrated Ashland or Coalton coal and the

$a$ Crandall, A. R. Report on the Geology of Greenup, Carter, and Boyd counties, and a part of Lawrence; Geol. Survey Kentucky, Report on the Eastern Coal Field, vol, C, 1884, pp. 1-78. 
"Ferriferous" limestone, $a$ with its important associated fire clay. This group may be readily recognized, as it rests on the Homewood sandstone and is capped by a similar massive bed lying above coal No. 9. It is variable in thickness. For example, southwest of Willard it thins from 130 to 90 feet in crossing a hill. Near Coalgrove, Ohio, it is approximately 180 feet thick.

A cut on the Norfolk and Western Railway near the mouth of Big Sandy River displays some of the most massive sandstones in the area. These form the base of the next higher formation. The rocks of this division are prevailingly shaly, usually bright green or red, with occasional beds of sandstone, some of which become very massive, together with beds of limestone and iron ore. This formation includes coals No. 10 and No. 11, and smaller seams up to the base of the Pittsburg coal. It corresponds to the Conemaugh formation of Pennsylvania, and where fully represented west of Centerville, W. Va., is about 300 feet thick. Above the Pittsburg coal occur 100 feet of higher beds belonging to the Monongahela formation.

\section{GENERAL DESCRIPTION OF COAL BEDS.}

There are workable beds of coal scattered through nearly the entire geological column as developed in this area, up to and including the celebrated Pittsburg coal at the base of the Monongahela formation. These coals vary widely in character and include most of the varieties of the bituminous class. The bulk belong to the harder bituminous variety, frequently assuming a splinty aspect. They usually break into blocks along charcoal layers, and hence may be classed as semiblock coals. They are unsuitable, in the main, for coking, but give excellent results for steam and domestic purposes. Nearly all bear transportation and stocking well. Coal No. 7, the Ashland or Sheridan seam, has found and still finds a ready market for furnace work: For convenience in reference and with a commercial rather than a scientific point of view, these coals will be described by districts as follows:

1. Big Sandy River.

2 Louisville and Lexington Railroad. .

3. State of Ohio.

4. Little Sandy River.

5. Eastern Kentucky Railroad.

BIG SANDY RIVER DISTRICT.

Though not the most important commercially, this district will be described first, since it includes the widest range of coals, comprising the horizons of all the coal beds in the area. It will thus serve as a natural introduction to the following descriptions: From the structure already outlined, it is evident that the lower beds should appear near the edge of the quadrangle, on the north, west, and south. What will probably prove on paleobotanic evidence to be the lowest coals in the area are the four thin seams showing in the section along the Chesapeake and Ohio Railway on Levisa Fork south of Chapman post-office. So far as known, these are not of workable thickness, the average of each being less than 12 inches. The lowest seam of any importance in this district occurs about 80 feet above this lower group and has been designated the "little cannel" coal from the presence in its main bench of a splint band containing sufficient volatile matter to place it among the cannel coals. It has been opened at Torchlight, near the railroad track, both above and below the tipple of the Torchlight Coal Company, where it occurs 140 feet under the Torchlight or No. 3 coal. Just south of the tipple a section shows 19 inches of coal with one-half inch of fire-clay parting near the base. To the north of the tipple 2 to $2 \frac{1}{2}$ feet of bright, clean coal containing bands of splint were seen. The northerly dips carry it almost immediately below drainage. On Threemile Creek this coal is workable

a This name was used by Andrews and other geologists in the reports of the Ohio Geological Survey. and it is accepted for use in this paper in the same sense, but in the final report a geographic nams for this bed of limestone will be proposed. 
and has been opened at a few points near Summit. Its.horizon is also above drainage on Lick Creek and Left and Right forks of Little Blaine Creek. For the present this coal may be tentatively correlated with the "clod seam" of the Little Sandy River region.

The next higher coal of economic significance in this region, No. 3 of the Kentucky Survey, may be referred to the Mercer group of the Pennsylvania section. This is among the most persistent of the workable coal beds in the quadrangle. As already mentioned, on Levisa Fork at Torchlight station it occurs 140 feet above the "little cannel" seam, disappearing below, drainage about a mile from the mouth of Threemile Creek. It is found in the hills south of a line drawn from Torchlight to Prosperity, and has been opened at a number of points on Lick Creek and Right Fork of Little Blaine Creek, showing a rather persistent and characteristic section. This fact, together with its massive sandstone roof and its position, from 120 to 140 feet below the Homewood sandstone, serve to identify it readily: A typical section is that at the Torchlight mine, the three benches of the main body of coal varying in thickness as the seam is traced to the west.

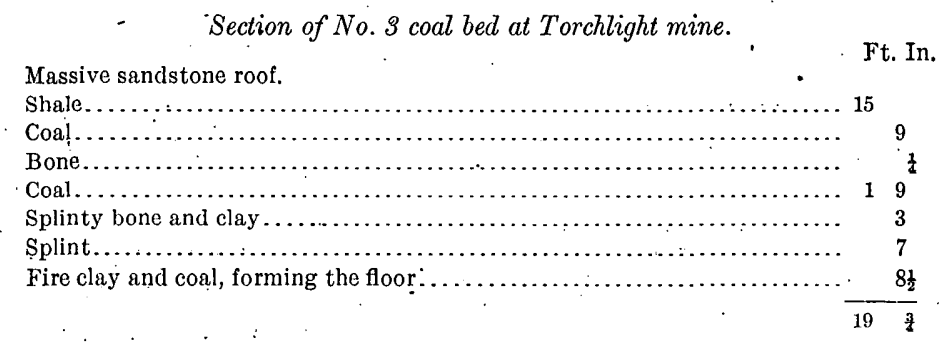

The next higher coal; No. 4 of the Kentucky series, is.not a very important bed, except in two restricted localities, namely, in the hills east and west of Levisa Fork and in the dividing ridges between Stinson and Straight creeks, Carter County. It usually occurs near the base of the Homewood sandstone, in some cases directly under this horizon, as on Catletts Creek, Boyd County. At Torchlight it is found 55 feet above coal No. 3, where it shows the following section:

Section of No. 4 coal at Torchlight.

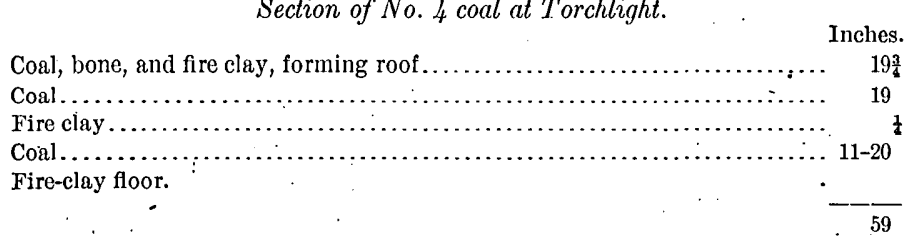

It will be noted that the main section of coal shows two benches- $a$ condition which exists where the coal outcrops along Lick Creek and also on the Kentucky side of Obio River near Ashland and Catlettsburg. The Lick Creek coal lies from 70 to 80 feet; above coal No. 3 and is the thickest.coal observed in the quadrangle. .A few sections obtained from openings on the property of the Louisa Coal Company in the divide between Lick Creek and Levisa Fork will well illustrate the character of this seam.

Sections of No. 4 coal on Lick Creek.

I.

Shale roof.

Inches.

Splint and bituminous coal mixed $\ldots \ldots \ldots \ldots \ldots \ldots, \ldots \ldots \ldots \ldots \ldots \ldots, 49$

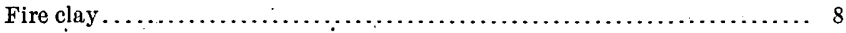

Soft, bright coal ............................................ 6

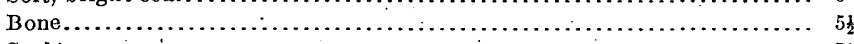

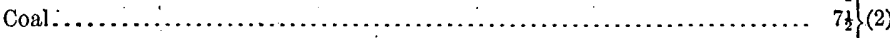

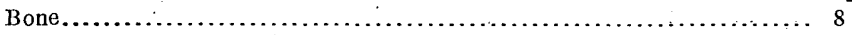

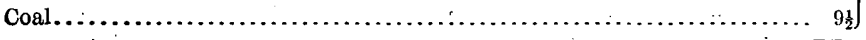


II.

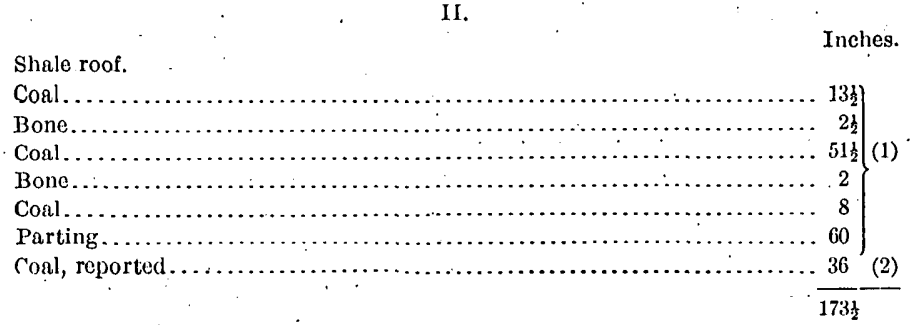

III.

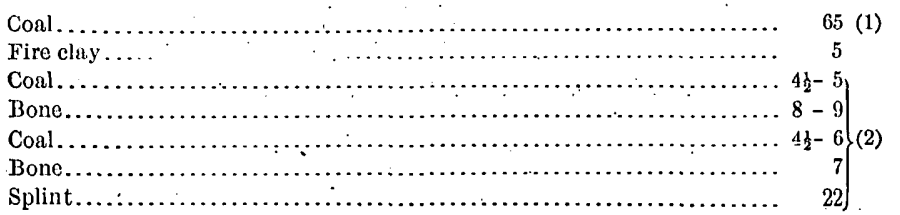

Fire clay.

$116-119$

An analysis of coal collected near the outcrop, kindly furnished by Mr. A. C. Collins, of Mount Vernon, Ohio, reveals the following composition:

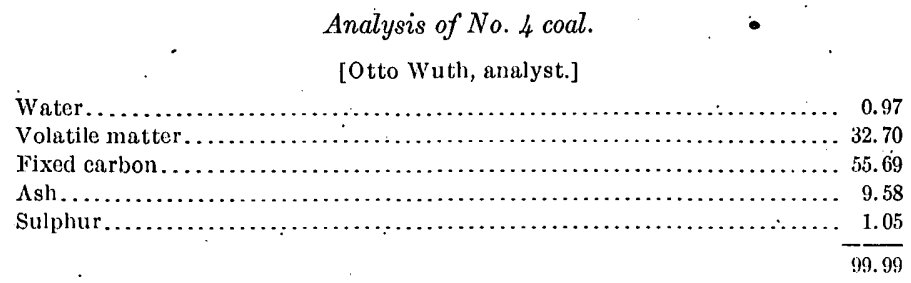

This same coal is brought above drainage on the opposite side of the basin near Catlettsburg. A section at a country bank on Catletts Creek is typical of this seam in this region, though the two coal benches are sometimes larger and sometimes smaller than the figures indicated. This section is as follows:

Section of coal underlying the Homewood sandstone on Catletts Creek.

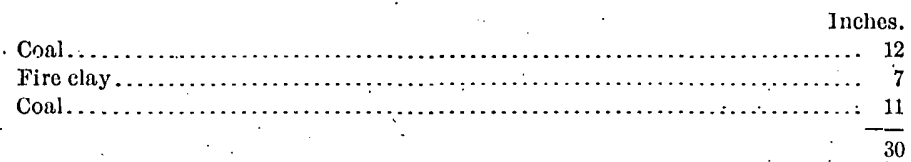

The group of coal beds described above is usually overlain by the massive Hoinewood sandstone, which lies a short distance below the "Ferriferous" limestone. In using this topmost member of the Pottsville formation as a guide, however, discrimination must be exercised, for, though it is most commonly present, it sometimes dwindles to a few feet of shaly sandstone. In the region under discussion the sandstone may be used without danger of error, since it is very thick and massive throughout the Big Sandy River area.

The rocks lying between the Homewood sandstone and the sandstone usually occurring above coal No. 9 are known as the Allegheny formation. In this interval occur the most important and best-known coals of northeastern Kentucky. A section taken at Coalgrove; Ohio, opposite Ashland, shows this formation to be about 180 feet thick.

North of Torchlight, along Levisa Fork, the Allegheny conls descend gradually toward the center of the basin. The lowest coal in this formation is not developed on a working scale in the Big.Sandy country, but No. 6, the next higher coal of the Kentucky series and the first seam above tbo "Ferriferous" limestone, has been spasmodically opened in the 
hills about Louisa and south of Cassville and measures 16 to 29 inches in the cuts recently made along the Chesapeake and Ohio Railway north of the former town. Its variability and small thickness in this region preclude the probability of its commercial exploitation in the near future. Coals No. 7 and No. 8 are not workable as a rule in the valley of Big Sandy River, while coal No..9, a relatively unimportant coal in most of the Kenova field, reaches its greatest development in this region. It has been opened along the river from the mouth of Horseford Creek north to Zelda station on the Kentucky side, and from the mouth of Tabor Creek to a point opposite Zelda on the West Virginia side. It averages in the neighborhood of 3 feet, though it attains a thickness of 40 inches in places, as at the bank of Alvin Stewart, opposite Zelda station. At Mr. Frank Yates's bank, a mile southwest of Catalpa, 4 feet of coal were measured, but this is above the average for this seam. At Fallsburg and Yatesville this coal is of workable thickness for local consumption, averaging between 25 and 30 inches. A section just outside of the former village measured 30 inches of coal, with a bony parting of 8 inches near the top.

From Zelda to the region about the mouth of the river the Conemaugh ("Upper Barren") formation stretches back into the country on both sides. From Buchanan to the mouth of Campbell Run the beds are very nearly flat, but northward from this point there is a gradual rise, well shown on the West Virginia side by the massive sandstones at the base of the Conemaugh formation. The succession of coals from No. 9 downward are also well exposed and some of them have been opened on Chadwick, Peterman, and Catletts creeks.

Near the center of the basin, at the top of the hills east of Lett post-office, W. Va., is the Pittsburg coal. This, stratigraphically considered, is the highest important coal in the region, and it marks the base of the Monongahela formation. According to Dr. I. C. White, $a$ this is the extreme southwestern limit of this coal bed. It has not more than 100 feet of covering at any point, its roof being shale, capped by 20 feet of massive Pittsburg sandstone. On Mr. James Adkins's property it measures 37 inches in thickness, occasionally reaching as high as 48 and even 54 inches, according to Mr. Adkins. It has also been opened by Mr. Abraham Thacker. Its small area hinders its exploitation except for the local country trade.

LOUISVILLE AND LEXINGTON RAILROAD DISTRICT.

In the Louisville and Lexington Railroad district will be included that area whose natural outlet is over this division of the Chesapeake and Ohio Railway. In this district will also be included the city of Ashland. From the latter point to Mount Savage, Carter County, the workable coals are confined to an interval not exceeding 80 feet above the "Ferriferous" limestone, or "red limestone" ore. Lower and higher coals occur in this area, but they are too thin to be of importance, with the possible exception of coal No. 3, opened in the bed of Little Hood Creek, about a mile west of Ashland. From Mount Savage westward the rapid rise brings up beds as far down in the Pottsville as the Sharon conglomerate.

The first coal above the "Ferriferous" limestone, for this reason known as the "limestone coal," is generally developed in Boyd County, especially in the hills about Ashland. Here it occurs embedded in massive sandstones about 40 feet above the limestone, as is also the case on the Ohio side at Coalgrove: It furnishes much of the fuel used in the city, and is utilized by the various brick plants in the eastern part of the town. At Winslow it has been extensively developed, and was mined and coked by the Ashland Iron and Mining Company up to the time of destruction of their washer. At the present time they are working but one mine, No. 8 , and this not to its full capacity, shipping only 150 tons per day to the works in Ashland. This coal has been worked as far south as Princess and it is of workable thickness in the country to the east as far as East Fork of the Little Sandy. It has been opened near Mavity post-office about 25 feet above drainage, but it dips to the south and southeast and soon disappears below water level. It does not reappear until the rise of the beds on the southeast border of the basin brings it to light near Louisa.

Where developed most extensively, as in the region about Ashland, the coal appears in

a Rept. West Virginia Geol. Survey, vol. 2, 1903, p. 191. 
three benches, if the small bone streak in the upper portion of the bed be considered a legitimate stratum for division. This trifold character has also been noted on Keyes Creek and at the mines at Winslow. At the latter place the two upper benches are hard and resistant, owing to the admixture of splinty layers, but the lower bench is so soft as to crush when left in pillars. Although an excellent steam and domestic fuel, it has not been found suitable for coking purposes. The following section was measured at No. 8 mine, at Winslow:

Section of No. 6 coal at Winslow.

Sandstone roof.

Ft. in.

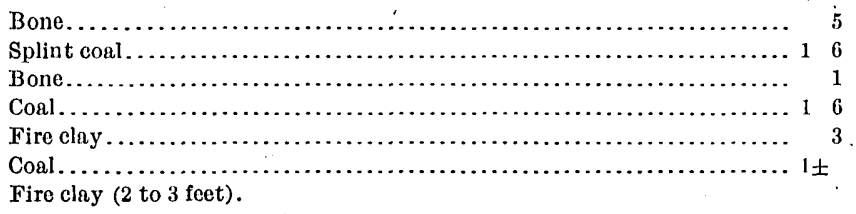

49

The second bed above the red limestone ore, 30 to 40 feet above the "limestone coal," is the Sheridan or Coalton coal, No. 7 of the Kentucky Survey and No. 6 of the Ohio Survey. This coal has been known and worked for many years in the Hanging Rock region, as this part of Kentucky and Ohio is sometimes called. According to the Ohio Geological Survey reports $a$ it is to be correlated with the "great vein," or Nelsonville and Straitsville coal of the Hocking Valley. Up to the present time it has proved by far the most important commercial coal in this area and, though much of the available coal above drainage has been removed along the railroad from Princess to Music, the great mass of the coal lying below drainage in the basin to the east has not been touched. It is found in the hills on both sides of the railroad from Music to Mount Savage, the rise of the rocks to the west, however, soon carrying its horizon above the hills. At the head of Davies Branch it is mined and shipped by the Straight Creek Coal Company; where it has a section indicated by column 3 in the table below. One and one-third miles to the east it is below drainage. Between Princess and Winslow this coal has been extensively utilized for domestic purposes, nearly every farm having had its individual bank at sometime or other, but in the Flatwoods country, between Winslow and Ashland, the hills rise barely high enough to reach it, though beyond Ohio River it again resumes its importance. To illustrate the uniformity of this coal the following sections are appended:

Sections of coal No. $\%$.

\begin{tabular}{|c|c|c|c|c|c|c|}
\hline & 1. & 2. & 3. & 4. & 5. & 6. \\
\hline & Inches. & Inches. & Inches. & Inches. & Inches. & Inches. \\
\hline 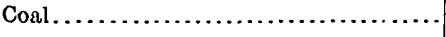 & 4 & $0-26 \frac{1}{2}$ & 8 & $0-18$ & .......... & n........ \\
\hline Parting...$\ldots \ldots \ldots \ldots \ldots \ldots \ldots \ldots \ldots \ldots \ldots \ldots$ & $5 \frac{1}{3}$ & 3 & 4 & 6 & 5 & 12 \\
\hline 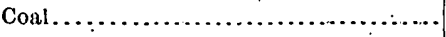 & 22 & $21 \frac{1}{2}$ & 24 & 22 & 24 & 18 \\
\hline Parting...$\ldots \ldots \ldots \ldots \ldots \ldots \ldots \ldots \ldots \ldots \ldots \ldots \ldots \ldots$ & 2 & 1 & 1 & 1 & $\frac{1}{4}-1$ & ... \\
\hline 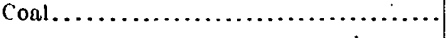 & $13 \frac{1}{2}$ & $18-23$ & 15 & 22 & 20 & 12 \\
\hline & 467 & $43 \frac{1}{2}-75$ & 52 & $51-69$ & $55 \frac{1}{4}-50$ & 42 \\
\hline
\end{tabular}

1. Section at Eastern Kentucky Railroad mine, east of Willard, Carter County, Ky.

2. Morning Glory Coal Company's mine, Grant, Carter County, Ky.

3. Straight Creek Mining Company, head of Davies Branch, Carter County, Ky.

4. Ashland Iron and Mining Company, mine No. 10, near Rush, Boyd County, Ky.

5. Princess Land and Mining Company's mine, Princess, Boyd County, Ky.

6. Country bank near mouth of Belle Trace Creek. 
In general, the roof of this coal is sandstone, while the partings may be either bone or fire clay.

OHIO DISTRICT.

The geological section in the hills of Ohio opposite Ashland is really a continuation of that on the Kentucky side. Both coals Nos. 6 and 7 are of importance and both have been worked. At the present time coal No. 6 is being mined at Coalgrove and shipped to Portsmouth, Ohio. Nothing on a commercial scale has been attempted within the last thirty years on the next higher or Sheridan seam, though much valuable unworked coal remains above drainage in the western two-thirds of Perry Township. $a$ The next higher coals in the series, the No. 8, or Hatcher seam, and No. 9, are of local importance only.

\section{LITTLE SANDY RIVER DISTRICT.}

The Little Sandy district, so far as coal resources are concerned, is coincident with the territory having its outlet to the north by way of the Eastern Kentucky Railroad, for to the west and south, from Leon to Rosedale, Carter County, the coals are too small to be worked except for local country use. In the following paragraphs will be considered those important coals lying in the drainage of Little Sandy River north of the Chesapeake and Ohio Railway.

The Little Sandy country lies well toward the western edge of the basin, and hence the coals occurring in this territory must be the lower seams. All the coals of any importance lie below the "Ferriferous" limestone and above the Greenbrier. limestone. The lowest coal in the region is the "subconglomerate seam" developed on Barrett.Creek, Carter County, and Canes Creek, Greenup County. It can not have more than local importance, owing to its thinness. At least two coal horizons occur between this "subconglomerate" coal and the so-called "clod seam" of the Argillite region. The latter seam, owing to a thick "clod," or clay parting, has little value except as a local fuel. It has been opened at many points in the hills near Danleyton and Argillite, on Culp Creek and Henry Branch, as well as in the hills near Hunnewell. It occurs on both sides of Little Sandy River, but the easterly dips carry it bèlow drainage as the Louisville and Lexington Railroad is approached. At a country bank one-fourth of a mile west of Danleyton, Greenup County, the following section was measured:

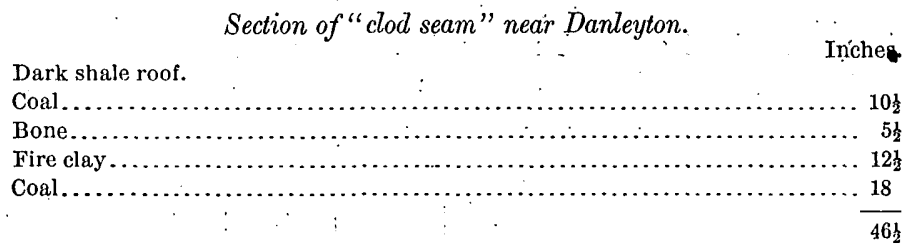

The coal is of the splinty variety and the large number of openings on it indicate that it is highly valued as a local fuel. Coal No. 3 , the stratigraphic equivalent of the Torchlight seam of the Big Sandy River region is present in all the hills of this region. In general, it is above drainage on this side of the basin only to the west of the Louisville and Lexington Railroad. At Boghead and Hunnewell this seam contains an important cannel bench, as the following section at Boghead shows:

Section of lower cannel seam at Boghead, Carter County, Ky.

Shale roof.

Inches.

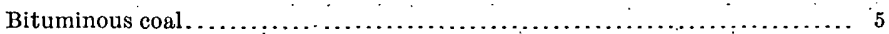

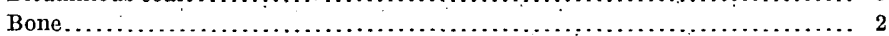

Cannel coal..................................................... 15

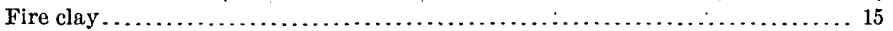

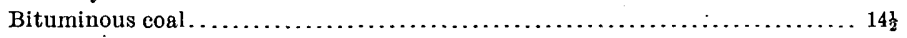


This coal is now being mined by the Kentucky Cannel Company at both the above localities and is shipped to Spain, where it is used in the manufacture of gas. Though the seam is found north of Turkey Fork, in Greenup County, it does not appear to carry the .cannel layer in this region.

The next higher coal is of workable thickness in certain parts of the Little Sandy country, though generally throughout the quadrangle it has proved unworkable except in the vicinity of Levisa Fork. At Boghead it appears 30 feet above coal No. 3 and about the same interval below the base of the Homewood sandstone. Here it is mined by the Kentucky Cannel Company in conjunction with the seam below, mainly for its cannel bench. A typical section of the upper Boghead coal shows the following structure:

\section{Section of Boghead coal (upper cannel seam).}

Shale roof.

Inches.

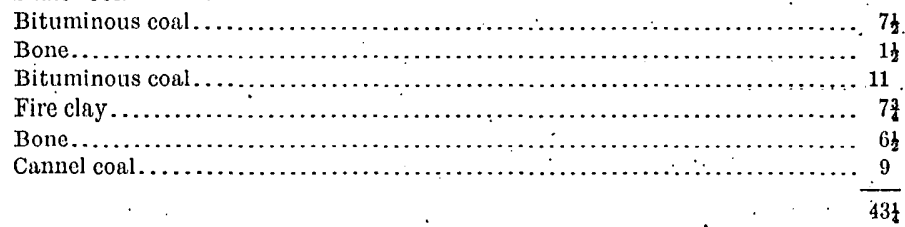

Southeast of Boghead, in the hills north of Upper Stinson Creek, some of this coal has been removed by the Lexington and Carter Coal Mining Company, but at the present time these old workings are fallen shut.

\section{REgION TRIBUTARY TO THE HEAD OF THE EASTERN KENTUCKY RAILROAD.}

This district includes the territory watered by Little Fork of Little Sandy River, including the Willard district as well as the important field at the head of Dry and Equal forks, and Elliott County.

About three-fourths of a mile southeast of Willard is found the center of a local basin. The beds rise both to the north and to the south from this point. The rise to the north is exceedingly rapid, and coal No. 7, which at Willard is 685 feet above sea level, is more than 900 feet above in the hills just north of Johns Branch. This rapid rise brings up the lowest horizons of the Pottsville group as developed in the western part of the quadrangle. A seam opened at the mouth of Field Branch is a representative of this group. Mr. Walter Field, who has worked this coal, reports 44 inches as an average. The writer measured 37 inches of clean coal at the mouth of Mr. Field's bank and did not reach the bottom of the bed. The .coal is splinty, rather dull in appearance, and gives excellent satisfaction as a domestic and steam fuel. These qualities, in connection with its low position in the hill, suggest the possibility of a good body of workable coal. The remaining coals in the Pottsville series in this territory are rather thin, though in many instances they thicken to respectable proportions and are worked for local use. This is true of coal No. 3 on Dry Fork, measuring 30 to 36 inches, and coal No. 4 on Hilton Branch, showing a bench of cannel of 26 to 29 inches, with $4 \frac{1}{2}$ inches of bituminous coal above and massive Homewood sandstone serving as a roof.

The interval from the Homewood sandstone to the "Ferriferous" limestone is variable in this region, as it is throughout the quadrangle. At Willard the interval is about 35 feet, while at the head of Cherokee Creek it is not more than 10 feet. At this locality the lowest coal in the Allegheny formation is well developed on the land of Mr. J. A. Young. This seam, No. 5 of the Kentucky reports, rests directly upon the massive Homewood sandstone and is but a few feet below the "Ferriferous" limestone. Its analysis and section serve to place it among the valuable coals in the region, while the territory occupied is fairly extensive, including the hills at the heads of Dry and Equal forks, Perkins Branch, and Cherokee Creek. 
Section of coal No. 5 from Young bank, at the head of Cherokee Creek, Lawrence County, Ky.

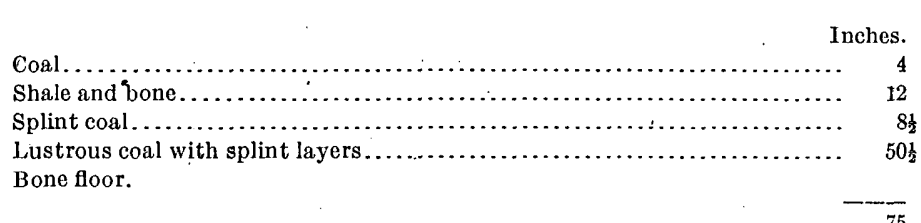

According to an analysis made by the Kentucky State chemist, a sample from the Young mine shows the following composition:

Analysis of coal No. 5 from Young bani.

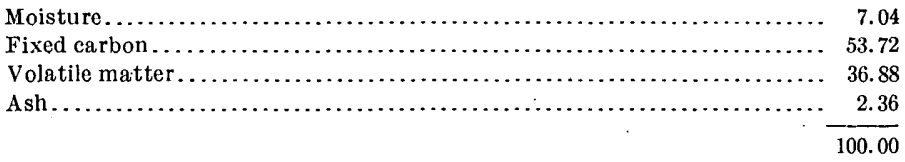

It is probable that this is the same coal which makes such an excellent showing well up in the hills north and south of Johns Branch.

Coal No. 7 maintains its importance in this region, and has been mined at Willard and as far south as Webbville. Several country banks'are working this coal on Belle Trace Creek and at Partloe. At the latter place the Eastern Kentucky Railroad is utilizing the coal for use in its engines and for shipment to various points along its track. Sections of this coal from a country bank on Belle Trace Creek and from the mine at Partloe have already been given (ste table, p. 265). 


\title{
DEVELOPMENT OF THE BEAR CREEK COAL FIELDS, MONTANA.
}

\author{
By Cassius A. Fisher.
}

Introduction.-During the field season of 1903 a prèliminary examination was made of the coal deposits of the Bighorn basin in northwestern Wyoming. At the close of this investigation, for the purpose of comparison, the writer made a brief examination of the Bear Creek and Red Lodge coal fields, which lie next north, in the southern part of Montana. Coal has been mined extensively at Red Lodge, Mont., for a number of years, but it is only recently that attention has been directed to the extensive development of the Bear Creek deposits. In view of this proposed development the Bear Creek deposits were revisited at the close of the last field season and additional data obtained regarding the character, thickness, and stratigraphic position of the coal beds and the present plans for development.

Previous work.-The first investigations in this field were conducted by Mr. J. E. Wolff, of the Northern Transcontinental Survey. $a$ W. H. Weed, of the United States Geological Survey, $b$ has since described these beds, in connection with other coal deposits in Montana, and a brief statement of the nature of the deposits was published by the late G. H. Eldridge.c

Location and extent.-The. Bear Creek coal district occupies the highland lying at the base of the Bear Tooth Mountains in the southwestern part of Carbon County, Mont., near the headwaters of Rocky Fork, a small tributary of Yellowstone River. The area underlain by coal is about 3 miles wide and extends in a northwest-southeast direction, the limits of which have been only indefinitely determined. On the south these coalbearing beds probably do not extend to the Wyoming State line, and to the west of Red Lodge they are covered by a considerable thickness of a more recent formation.

Stratigraphy.-The coal of the Bear Creek district occurs in the upper part of the so-called Laramie formation, which here consists of a series of alternations of sandstone, shale, and clay of variable thickness. The shales are dark gray and usually very sandy. The sandstones are lighter gray and often iron stained. They occur in beds 25 to 30 feet thick and are generally sufficiently soft to weather uniformly with the intercalated shales.

Coal.-The coal occurs within a series of beds less than 600 feet thick and in this mass there are at least seven workable coal beds. They vary in thickness from 4 to $10 \frac{1}{2}$ feet and comprise a total of $\varepsilon$ pproximately 45 feet. These different coal beds are designated as Nos. 1 to 7, beginning at the top. No. 1 has a thickness of 6 feet, with a few thin partings near the middle. No. 2 is $6 \frac{1}{2}$ feet thick and is overlain by a dark shale of variable thickness. No. 3 has a total thickness of $10 \frac{1}{2}$ feet, with a parting of varying width near the middle. The roof is hard, rendering it unnecessary to timber the rooms and entries. No. 4 is $4 \frac{1}{2}$ feet thick and contains a few small partings. No. 5 has a thickness of $4 \frac{1}{2}$ feet, with one small parting of bony coal. The roof of No. 5 is composed of massive gray sandstone; the floor of a gray, compact clay. No. 6 has a total thickness of about $4 \frac{1}{2}$ feet,

a Wolff, J. E., Report on the Rock Creek coal field, Montana: Tenth Census of the United States, 1886 pp. 755 and plates.

$b$ Weed. W. H., The conl fields of Montana: Eng. and Min. Jour., vol. 53, No. 20, is82, pp. 520-522.

$c$ Eld ridge, G. H., A geological reconnaissance in northwest Wyoming: Bull. U.S. Geol. Survey No 119,1894, p. 53. 
but contains a few shale intercalations. No. 7 , the lowest in the series, is $8 \frac{1}{2}$ feet thick of clean coal. Below this there are several small seams which are not of workable thickness.

Development.-Coal was discovered in this general region in 1884 and the first opening was made in 1887 at "Yankee. Jim Claim," which occupied the present site of the Red Lodge mine. During the two succeeding years the output of this mine was small, but in 1889 shipments were begun and since that time there has been an average annual production of 600,000 tons. This mine is now owned by the Northwestern Improvement Company. While the coal deposits of the Red Lodge district were known to extend to the south and some prospecting had been done in the head of Bear Creek, no material development took place in this field until 1900, when the Montana Fuel and Iron Company opened a small mine and began shipping coal. During the last four years the total product of this mine has probably exceeded 6,000 tons, having a market value of $\$ 3.30$ a ton. - As Red Lodge is the nearest ${ }^{\circ}$ shipping point to the Bear Creek mine, it was necessary to haul the coal a distance of 4 miles over a very hilly road. This materially increased the cosst of production and made it necessary to place the coal on the market at a higher price than the Red Lodge coal, which has a shipping value of about $\$ 2$ a ton.

At present the Yellowstone Park Railroad Company is building a railroad from Bridger, Mont., up Clark Fork Valley and thence up Bear Creek to the mines, a distance of about 25 miles. Two town sites have been laid out along the new line, one at the mines, known as Bear Creek, and another called Belfry, at the mouth of Bear Creek. A large plant is now being built one-half mile west of the town of Bear Creek by the Bear. Creek Coal Company, and is to be equipped with all modern appliances for mining coal of this character. The company has about 1,600 feet of gangways driven on seams Nos. 2 and 3 and, as a result of this development, several thousand tons of coal are now at the mines ready for shipment. Substantial quarters are being constructed for a large force of miners and the company expects to have a large tonnage of coal ready for shipment when the new.railroad is completed.

Four companies have extensive holdings in the Bear Creek fields. They are the Bear Creek Coal Company, the Montana Fuel and Iron Company, the Northwestern Improvement Company (the present owners of the Red Lodge coal mines), and the Anaconda Copper Company, also known as the Amalgamated. Of these companies, only the Bear Creek Coal Company is making preparations to develop, but the Montana Fuel and Iron Company expects to increase its output as soon as railroad facilities are available. 


\section{CLEARFIELD COAL FIELD, PENNSYLVANIA.}

By George H. Ashley.

Introduction.-Clearfield coal, from Clearfield County, Pa., has long been one of the standard coals for comparison all through the Appalachian region. It is regularly quoted on the eastern markets, and with 70 per cent or over of fixed carbon, 22 per cent of volatile matter, and 8 per cent of waste, it is typical of the highest grade of bituminous coal, especially of the so-called "semibituminous" class. To-day interest in this coal field centers in its present condition and the possibilities of its extension in different directions. 'This paper is based on recent field work on the Houtzdale, Curwensville, and Punxsutawney quadrangles, which cover nearly all of the southern half of Clearfield County, and include the famous Moshannon coal basin, from which all of the original Clearfield coal was derived. (See fig. 11.)

Structure.-This area is divided into two basins by a broad arch which enters the county from the south between Coalport and Westover, then passes northeastward near McCartney, between Belsena Mills and Boardman, to a point between Wallaceton and Bigler. This arch, which rises and is very broad toward the northeast, lifts the rocks until practically all the workable coals have been removed northeast of Belsena Mills. To the southeast of this arch lies the old "first basin" of the First Pennsylvania Survey, in which occurs the Moshannon coal, while to the northwest lies the "second basin." The coals of this district belong mainly in the Lower Productive Measures, or Allegheny formation, including the beds from the Brookville or Clarion coal up to the Upper Freeport coal. The presence of ten to twelve coals, as against seven at the type locality, the known splitting of both the " $\mathrm{D}$ " and the " $B$ " beds, and the limited data over many areas have led to a continuation of the use of the letters as used in this field by the mining men, running from " $\mathrm{A}$ " for the Brookville coal to " $\mathrm{E}$ " for the Upper Freeport coal. By the use of these letters it is intended to suggest relative position and approximate correlation, without implying exact correlation. The principal coals to which they are applied lie from 40 to 60 feet apart through a vertical space of 250 feet. Of these the most important coal has the relative position of the Lower Freeport coal, or coal "D," on Allegheny River.

Moshannon basin.-The two basins may be again subdivided for purposes of detailed discussion into a number of subbasins, to be treated in order from northeast to southwest. Of these the first is the Houtzdale-Osceola, or old Moshannon basin, including the coal lying in the Moshannon Creek and Beaver Run drainage. This basin lies along and just within the southeastern edge of the county, from a point a little southwest of Houtzdale northeastward. It has furnished most of the coal known on the market as Clearfield coal, and is still supplying a large portion of that coal. The " $D$," or Moshannon seam, as it is locally known, has a thickness all through this basin of from 4 to 6 feet, running occasionally much over the upper figure and averaging about 5 feet. While the heart of the seam in this basin has already been taken; there is still some coal left around the edges of the basin and in the center, where in the early days tracts of coal slightly inferior in thickness or quality were passed by. These remnants are being rapidly removed by a large number of small shipping mines. There are still a few large. mines operating in this field, but apparently on bodies of coal which are fast approaching exhaustion.

Bull. 285-06-18 


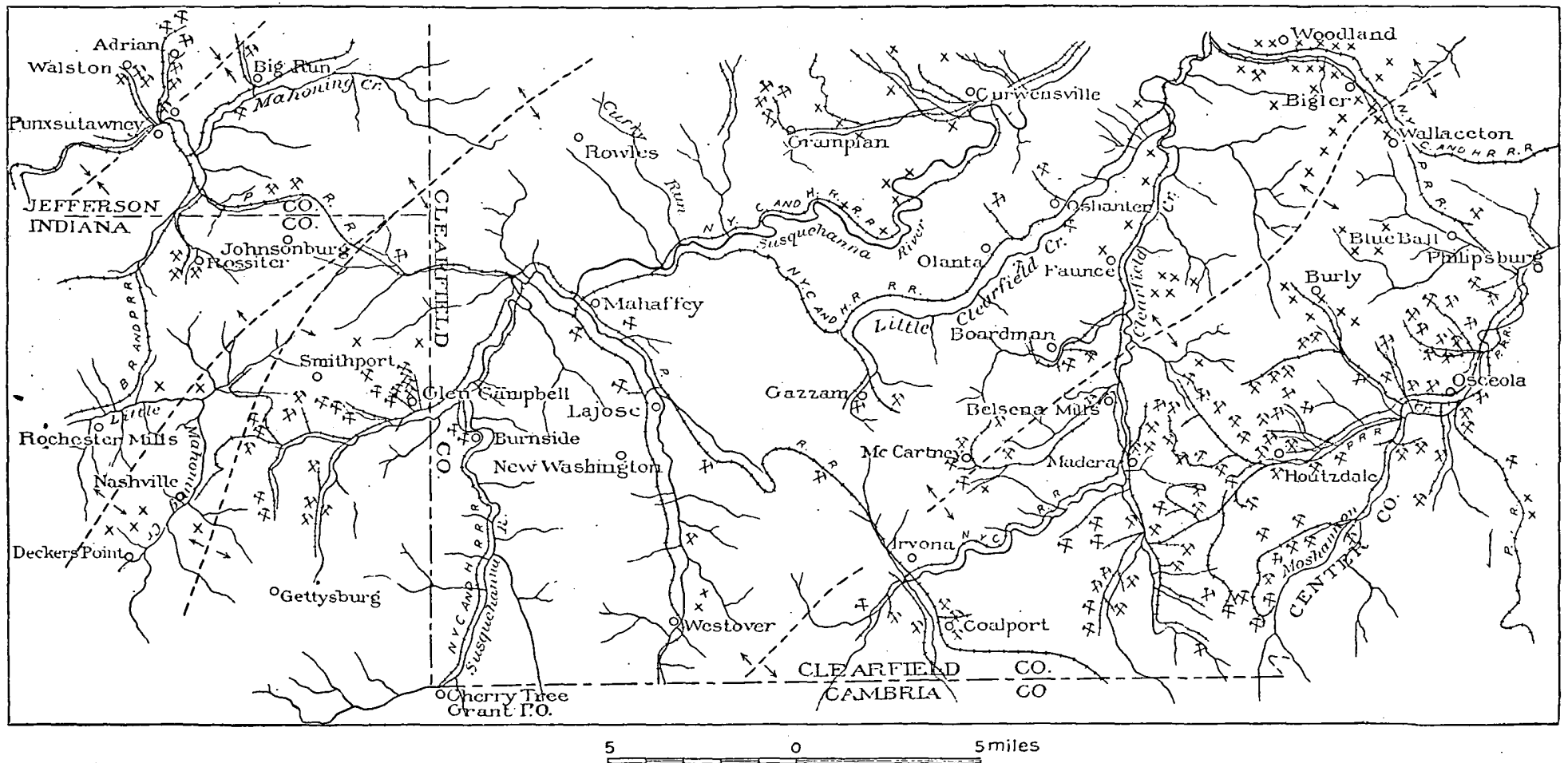

FIG. 11.-Sketch map of southern Clearfield and parts of Indiana and Jefferson counties, Pa. Crossed hammers, coal mines; X, clay mines or outcrops. 
The "E," Upper Freeport, or "cap" seam, as it is locally known, is in this basin poorer in quality than the " $D$ " and has a thickness of only 3 feet. At present it is mined only on a small scale. It overlies nearly the same area as the Moshannon seam. Below the "D" seam, coals which are locally workable occur at four different horizons. The first is over 100 feet below, showing 3 feet in places, with a local thickening up to 6 feet or over, due to the presence of several feet of cannel coal. The "B" coal lies about 165 feet below the " $\mathrm{D}$," and shows a thickness of from $2 \frac{1}{2}$ to 6 feet. As a rule it is broken up with partings, and tends to carry a larger percentage of sulphur and ash than the "D" coal. This coal often shows three benches, the two upper ones only being worked. The parting is usually bone, but in places is fire clay or sandstone with a thickness of from a few inches up to 4 feet. The middle bench is commonly 3 feet or more thick, and below it is a parting of several feet of hard, knarly clay, then a bench of 18 inches of coal. There is generally a thin rider over this seam within 20 feet. About 220 feet below the " $D$ " conl is the " $A$ " or " $A$ " " seam. While thin in places, this seam may show a thickness of up to 6 feet. Over part of the district it shows two fairly regular clay bands, but generally has many thin, irregular streaks of dirt and is very sulphurous. A seam 30 or 40 feet still lower shows in some of the drillings and in outcrop to the west. This may prove locally workable, though it hardly appears so with the present data. Over a large share of this district the coals below the " $\mathrm{D}$ " are below drainage and therefore will present large areas if they prove to maintain workable thicknesses.

Mudily Run district.-The second district includes the conl on the Muddy Run drainage above Banian Junction. It is characterized mainly by the splitting of the " $D$ " or Moshannon seam. West of Houtzdale this coal becomes irregular and locally wanting, but recovers a little farther west, only to split into two benches, which may be as much as 55 feet apart. The lower bench, which alone is mined, at present averages but little over 30 inches thick, but as it maintains the excellent quality of the coal in the first district it finds a ready market and can be worked with profit. This coal appears to run fairly regularly over this whole district. The upper bench and "cap" seam are both thin -2 feet or less. As the lower bench of " $D$ " seam is near drainage in this district, no mining has yet been done on the underlying seams and but little. is known of them. Drillings indicate one or two beds below of barely workable thickness in places, though locally there appears to be no workable coal below the lower bench of the Moshannon.

Wallaceton district.-The coals flanking the anticlinal arch to the northeast may be next considered: These districts are characterized by the fact that the lower conls outcrop and are workable, while the "D" coal is absent or of minor importance. In the Wallaceton region the " $\mathrm{D}$ " coal is absent, but the " $\mathrm{A}$ " and " $\mathrm{B}$ " coals are both of workable thickness. The " $\mathrm{C}$ " and " $\mathrm{C}$ " coals occur in that region and locally reach 3 feet or more, but generally are under 2 feet in thickness. As they are clean coals, they may be of value in the future. The " $A$ " and " $B$ " coals are very much alike, running from 2 feet 6 inches to 4 feet in thickness, each in two benches separated by a clay parting, which in the " $B$ " coal ranges from 10 inches down, and in the " $A$ " coal from 22 inches down.

Madera-Irvona.-In the region about Madera the " $\mathrm{D}$ " coal occurs near the tops of the hills, but has been largely removed. The principal coal of this district occurs about 220 feet below the "D" coul and is designated as the " $\mathrm{A}$ " seam, or, since there is a small coal still below it, it may be called the " $\mathrm{A}$ " " seam. It shows a thickness of up to 4 or 5 feet of minable coal, but often carries a large amount of cannel-like bone near the top. There is usually one thin parting and occasionally two. The "B" coal of the Houtzdale district has been worked to some extent south of Madera, showing about 3 feet of coal. To the west of Madera the anticline plunges toward the southwest, becoming low enough to carry considerable areas of the " $D$ " coal around McCartney, where this coal is locally 5 feet or more thick. It does not appear to maintain this thickness over any considerable area. Around Irvona and Coalport the " $\mathrm{D}$ " coal is unimportant, probably maintaining its split condition from the northeast, while the " $\mathrm{B}$ " coal has a thickness of up to 6 feet and will run from 3 feet 4 inches of nearly clean coal to 5 feet. It shows two bony partings, the 
upper one from a knife edge to 13 inches thick and the lower up to 9 inches thick, dividing the coal into three nearly equal benches. The " $\mathrm{C}$ " " and " $\mathrm{E}$ " coals in this part of the basin run from 30 inches down, though in a small area west of McCartney the " $E$ " seam shows a thickness of 5 feet of coal, apparently of poor quality, and northwest of Irvona the " $\mathrm{C}$ " coal thickens up locally to 4 feet. The " $\mathrm{A}$ " and " $\mathrm{C}$ " coals are less than 2 feet thick.

Little Clearfield Creek district.-In the second basin there may be considered first the coal along the Little Clearfield Creek drainage, reached by the Pennsylvania division of the New York Central and Hudson River Railroad. The "D" or Moshannon seam is the coal principally mined in this drainage area. It ranges from 18 inches to 4 feet in thickness, but will average under 3 feet. Its excellent qualities, however, allow its profitable mining even where it does not average over $2 \frac{1}{2}$ feet, and the commercial mines have taken coal as low as 17 inches. Around Oshanter it will range from 30 to 40 inches, with one-half inch to 2 inches of shale 5 to 10 inches from the bottom, and it usually carries a bone layer on top. Of the other coals the " $\mathrm{E}$ " reaches a thickness of 30 inches in places near. Oshanter and on the headwaters of Little Clearfield Creek, but will probably average about 2 feet. The " $\mathrm{C}$ " and " $\mathrm{C}$ " coals appear to be less than 2 feet in thickness. The " $\mathrm{B}$ " coal ranges from 2 feet 6 inches to 4 feet around Oschanter and 3 feet around Olanta. The " $A$ " coal ranges from 40 to 55 inches near Oshanter, but appears to be less than 2 feet farther upstream. On the whole it appears probable that the " $E$," " $B$," and " $A$ " seams will each yield some workable coal. The " $E$ " lies well up in the hills and carries a small body of coal. The " $A$ " and "B" are at or below drainage level and underlie all of this territory.

Grampian district.-The district centering at Grampian lies between West branch of Susquehanna River and the anticlinal arch, running parallel to and 5 or 6 miles north of the river. This region appears to be all underlain by the " $D$ " coal, with an average thickness of 3 feet. West of Grampian and on Cherry Run it locally reaches 6 feet. Most of the sections of this coal show a parting of clay shale or bone from 2 to 8 inches from the bottom. The "E" coal in this district ranges from 18 to 30 inches, averaging less than 2 feet, but is a solid coal. On the arch to the north of McGees it is locally more than 3 feet in thickness. The " $\mathrm{C}$ " " coal shows 30 inches without partings near Rowles. The " $\mathrm{B}$ " coal yields from 18 to 42 inches, with an average of a little over 2 feet of solid coal. The " $A$ " "or " $A$ " seam shows from 18 to 28 inches of solid coal around Curwensville, but appears to be thinner to the west. On the whole the " $\mathrm{D}$ " coal is the important coal of this district, and is probably workable over most of the area of its outcrop. The "B" and the " $E$ " coals may prove to be workable over considerable areas, and the " $A$ " and " $C$ " " coals may be locally workable:

Burnside district.-The southwest corner of the county is included in the upper Susquehanna or Burnside district. The coal mined at Burnside, thought to be the " $D$ " seam, has a thickness of 4 feet 6 inches, with one parting. On lower Cush Creek is a coal, either "E" or "D,". showing from 3 feet to 3 feet 6 inches of coal, with a 2 to 5 inch parting 10 to 14 inches from the top. But little mining has been done on the coals of this district, but considerable drilling has been done to determine the character of the coal beds in advance of development. This work has shown that in certain localities no workable coal will be found, while in other localities beds from 3 feet to 3 feet 4 inches lie at distances of between 200 and 300 feet below drainage. North of Burnside the rocks rise so that the Pottsville is above drainage for some distance above and below McGees Mills and up Beer Run. This rise throws the coal beds well up into the hills. It is probable that a large share of this district will yield at least one coal of workable thickness, and locally areas showing two workable coals may be found.

Summary.-It will be seen that according to present information the coals of southern Clearfield County, taken as a whole, are about 3 feet thick, though locally running up to 6 feet. Apparently a large share of this half of the county appears to be underlain by at least one coal bed from $2 \frac{1}{2}$ to 3 feet in thickness, most of which, on account of the excellent quality of the coal, may be counted as a source of fuel for the future. 
At the present time the largest producers in this field are the Berwind-White Coal Mining Company; Irish Brothers; Peale, Peacock \& Kerr; and the Morrisdale Coal Company, each of which mines about half a million tons. There are no very large mines in the area immediately under consideration. None of the mines yields over 200,000 tons a year, and most of them yield less than 25,000 tons. They are practically all nongaseous; the majority of the smaller mines still use the furnace for ventilation, while the larger mines use fans, two of these being of the Capell type. About half a million tons of coal are mined by machine, 74 machines being used in 1903 in 12 different mines. Of these machines 5 are electric and the rest use compressed air. Only a small amount of coke is now produced in this district, amounting to less than 100,000 tons, the largest production being at Irvona, where there are 100 ovens. Seven of the mines make use of 20 electric motors for haulage, and 2 steam engines are used. Most of the mines can not be classed as up to date in their mining equipment, though a few of the large mines, as suggested above, are well equipped. 


\title{
THE PUNXSUTAWNEY AND GLEN CAMPBELL COAL FIELDS OF INDIANA AND JEFFERSON COUNTIES, PA.
}

\author{
By Frederick B. Peck and George H. Ashley.
}

\section{INTRODUCTION.}

Location.a-The Punxsutawney and Glen Campbell coal fields lie just west of the Clearfield County field, which is described in another paper of this bulletin (pp. 271-275). The area discussed is included in the Punxsutawney quadrangle. The Punxsutawney field is of especial interest, as it contrins some of the largest coal mines in the United States in point of production as well as the largest continuous bank of coke ovens.

Coals and associated rocks.-The rocks outcropping embrace the lower half of the Pennsylvanian (Upper Carboniferous) series. These include the Allegheny formation, or Lower Productive Measures, with a thickness of from 250 to 300 feet, which carries the Freeport, Kittanning, and Clarion groups of coals. These rocks outcrop over a little less than half of this quadrangle. The rocks' between the upper Freeport and Pittsburg coals, of which about 300 feet remain, cover a little over one-half of the area. The Pottsville sandstone, with the Mercer coals, of little or no value, outcrops over limited areas on little Mahoning Creek abovè Richmond and on Bear Run and Susquehanna River around McGees Mills. The Allegheny formation contains from seven to ten coals, the principal seams being from 40 to 60 feet apart. Some of the area does not contain any workable coal. Much or most of it does not show more than one good workable bed, but sometimes one or more thin beds occur that may be worked in the future. Limited parts of the area contain more than one workable bed. In these fields the letters are commonly used to designate the beds, beginning at the bottom. The correspondence to the coals of the Allegheny Valley is as follows: " $A$ " represents the Brookville, " $A$ " " the Clarion, " $B$ " the Lower Kittanning, " $\mathrm{C}$ " and " $\mathrm{C}$ " the Upper and Middle Kittanning, respectively, and " $\mathrm{D}$ " and " $\mathrm{E}$ " the Lower and Upper Freeport, respectively.

Structure.-The Chestnut Ridge and Richmond anticlines, which enter the quadrangle on both sides of the southwest corner, appear to unite in northeastern Indiana County and to continue to the northeast as a single arch. The Punxsutawney basin lies to the northwest of this arch and the Brush Valley basin to the southeast. The "B" coal, which has an elevation of 2,100 feet on the crest of the arch at the corners of the three counties, has an elevation of 1,050 feet along the axis of the Punxsutawney syncline and lies from 150 to 250 feet below drainage. To the southeast the same coal descends to below 1,300 feet above tide into the Brush Valley basin. On the crest of the arch the rocks lie nearly flat, but on the flanks they dip into the basins at a rate of from 2 to 10 feet in 100 . The top of the arch toward the northeast is fairly broad and flat and in that direction is capped by the Mahoning sandstone, which overlies the "E" coal. From the northeast corner of Indiana County toward the southwest erosion has cut down and removed the " $\mathrm{E}$ " and " $\mathrm{D}$ " coals over much of the crest, those coals occurring only in the high points. 


\section{THE COALS.}

\section{PUNXSUTAWNEY BASIN.}

For convenience of discussion the different fields may be given in order, beginning at Punxsutawney. In this basin practically all mining at present is on the " $D$ " coal. The " $\mathrm{E}$ " coal, which overlies it at an interval of from 38 to 43 feet, reaches a thickness of 3 feet 4 inches over a considerable area northeast of Punxsutawney, but appears to run out to the east and south. Future mining on this bed will depend on the extent to which the work on the " $\mathrm{D}$ " coal has disturbed it. The coals below the " $\mathrm{D}$ " are below drainage through most of this basin, and little is known of their thickness and character, but it is claimed that they are not workable. The " $D$ " bed ranges from 4 to 6 feet in thickness, running up to 10 or 11 feet locally. Around Adrian, Walston, and Elk Run it will average about 5 feet 6 inches. Toward Big Run and Eleanora it is thinner, ranging from 4 to $4 \frac{1}{2}$ feet, and toward Winslow it thins to less than 4 feet. For a distance south of Punxsutawney all the coals appear to be absent or thin. Around Rossiter one of these coals comes in with a thickness of from 3 feet 8 inches to 4 feet 6 inches, thinning to the northwest and thickening to the southeast. This has generally been called the "E" coal. There is, however, at an interval of 40 feet above it a trace of coal underlain by clay, and that again by limestone, which come directly below what is considered to be the Mahoning sandstone. We have, therefore, considered the Rossiter conl as the "D" coal.

The " $\mathrm{D}$ " coal through the Punxsutawney basin is usually free from partings, but in the vicinity of Big Run and Winslow shows 1 or 2 inches of bony coal 10 to 12 inches from the bottom. Over the coal are often from 8 to 9 inches of bony coal. The roof is shale, generally showing a thickness of 12 to 14 feet or more, but in places it is thin and overlain by a sandstone that comes down close to or lies directly upon the coal. Where the shale of the roof is thin it is inclined to be tender, and in places this prevents the use of machines in mining. The floor shows from 2 to 4 feet of clay.

\section{GLEN CAMPBELL OR CUSH CREEK FIELD.}

The field work in the region about Glen Campbell has not yet been completed, so that many questions of correllation still remain to be settled. The general facts, however, may be stated at the present time.

Around Glen Campbell and to the northeast and northwest the " $\mathrm{E}$," "D," and " $\mathrm{C}$ " " coals are all being worked commercially. Just under the Mahoning sandstone, which north of Glen Campbell is very massive, occurs the "E" coal, which is about 4 feet thick. North and west of Smithport it is often broken up with bony partings. From 18 to 30 feet lower occurs the " $\mathrm{D}$ " coal. Locally this shows as two large benches, each broken with partings, giving a total thickness of 16 to 19 feet. These benches will yield from 3 to 6 feet of workable coal. It has been suggested that the " $\mathrm{D}$ " and " $\mathrm{C}$ " coals have come close together at this point. Most of the openings around Glen Campbell on the " $\mathrm{D}$ " coal show from 6 to 18 inches of bone, or bone and coal, with a lower bench of from 3 to $3 \frac{1}{2}$ feet of good conl," having 1 inch of bone a little less than halfway from the bottom. From 30 to 40 feet below the " $\mathrm{D}$ " coal is the " $\mathrm{C}$ " coal, which is being worked about Glen Campbell and" which there shows a thickness ranging from 4 feet 6 inches to 6 feet, with from 1 to 2 inches of soft bony coal 8 to 12 inches from the top.

Drillings north of Glen Campbell indicate that both the " $C$ " and " $B$ " coals are present in workable thickness. The " $\mathrm{C}$ " coal in one drilling is reported as 9 feet thick, but an adjacent drilling showed only 3 feet of coal and rock at the same horizon. The " $\mathrm{B}$ " coal appears to have a thickness of from 3 to over 4 feet; still below that are a number of coals, usually not of workable thickness. On the whole, the region close about Glen Campbell seems to yield a large number of workable coals, but these coals are often broken up by partings so as not to be economically minable. 
South of Glen Campbell and Smithport, between Susquehanna River and Little Mahoning Creek, rcarly all the mining appears to be on one seam, which is tentatively correlated with the "D" coal. It presents a remarkably persistent section. Nearly every measurement made on it shows from 3 to 9 inches of bony coal at the top, in places resembling cannel coal; then a main bench of coal from 3 feet to 3 feet 8 inches thick, a shale parting 1 to 2 . inches thick, and a lower bench of coal from 3 to 6 inches thick. The roof is always shale. At most points neither the drillings nor road sections show any coal above that being worked, so that that bed has been widely correlated with the " $\mathrm{E}$ " coal. At a few points there appears to be a coal above, and as this coal seems to connect with the " $D$ " coal around Glen Campbell it has been correlated tentatively with the "D" coal, as stated above. The Mahoning sandstone can not certainly be recognized in this area and therefore does not help in solving the problem.

To judge frem the openings made on this coal, it will be persistently workable under all of the area within its outcrop south and southwest of Glen Campbell to Little Mahoning Creek, and, as it is below drainage over much of the center of the Glen Campbell basin, it will present a large body of workable coal.

Below this coal there appear to be at least two coals which are locally or generally workable. The first occurs about 50 feet below and shows a thickness of from 2 to over 3 feet. It is a solid coal and has been opened at a few points along the drainage of Little Mahoning Creek. At a distance of from 134 to 178 feet lower drillings show coals which are locally from 3 to 4 feet thick, though some drillings fail to find more than a few inches of coal at these depths. It does not appear certain that these lower coals are all at the same horizon. Tentatively. they have been assumed to be such and have been correlated with the " $B$ " coal. The "B" coal outcrops on Hortons Run just west of Glen Campbell and along the valley of Little Mahoning Creek, in both of which areas it shows a workable thickness. Aside from these exposures this bed is below drainage over all of this basin, as well as below the anticlinal arch. If further prospecting, therefore, shows it to maintain a workable thickness, it may be counted on to yield a large amount of coal in the future.

\section{IITTLE MAHONING CREEK DISTRICT.}

Under this heading may be considered the coal in the drainage of Little Mahoning Creek from Richmond to Deckers Point. The Pottsville sandstone outcrops in the bottom of the valley between points below Richmond and above Nashville. . From 50 to 100 feet above the sandstone through all of this district lies the "B" coal, which locally shows a thickness of over 4 feet to the north of Richmond and of 3 feet in the valley above Nashville. Around Roberts this coal appears to be too thin and broken up to be worked. Just south of Richmond a coal, which appears to be either the " $B$ " or "C," reaches a thickness of from 5 feet to 5 feet 3 inches and is overlain by 5 or 6 inches of bony coal. The " $\mathrm{C}$ " coal shows a thickness in the hills southeast of Richmond of from 2 feet 8 inches to 3 feet of coal, with 1 inch of shale 4 inches from the bottom. Above it the " $\mathrm{C}$ " " coal has been opened at several points and shows a variable thickness, sometimes as great as 4 feet. The " $D$ " seam appears to have been opened at several points and shows from $2 \frac{1}{2}$ to 4 feet of coal, in all cases apparently overlain by a few inches of bone, which locally may thicken to as much as 14 inchés. The " $\mathrm{E}$ " bed has been opened at a number of points and locally shows 3 feet of coal. In all of this district the data on the coal are so scattered that it can not safely be stated how large bodies may be found of the thicknesses given. From what has been seen of the coal, however, it seems safe to predict that the district will yield a fairly large amount of workable coal, notwithstanding the fact that, owing to the presence of the anticlines, the coals lie high in the hills as compared with the two preceding districts.

\section{DEVELOPMENT:}

The Punxsutawney field is characterized by a few large mines rather than many small ones. These mines, if not the largest, are among the largest in the State of Pennsylvania, which places them among the largest in the United States. The Adrian, Florence, and 
Canoe Ridge mines all have or have had an output of 3,000 tons or over a day. The Florence and Adrian mines and Elk Run shaft, which are continuous, yielded in 1903 1,708,744 tons; the Walsion mires, Nos. 3, 4, and 6, which also connect with the mines just mentioned, yielded over 850,000 tons in 1903; and the Canoe Ridge mine has now an output of about 800,000 tons. The Adrian and Eleanora mines have each produced in the neighborhood of 1000,000 tons for several years, the Eleanora surpassing that mark in 1899 and the Adrian in 1900. The fact that these mines work all night is an important factor in this production. Of this output the larger portion is machine mined. Thus the Rochester and Pittsburg Coal and Iron Company, out of a total output in this field in 1903 of $3,240,000$ tons, mined 2,729,000 tons by machines, using 128 machines for that purpose, all of the compressed-air type. The product of several of these mines goes largely into coke. Of the 2,000 tons a day yielded by Walston mines Nos. 1 and 3, all passing through a 6 -inch sireen (1,700 tons) is converted into coke. The company has here 657 coke ovens in one continuous row, said to be the longest in the country and to contain also the largest number of ovens. The coal is crushed and sized, then washed to remove the slate and sulphur, a ter which it is stored in bins to be used in charging the ovens. At Adrian the output is 2,700 long tons daily, or 60,000 tons per month. The coai is a little harder, so that only about one-half of the output passes a 6 -inch screen. There are here 511 bee-hive coke ovens, arranged in a double row a mile long. Experience shows that 34,000 tons of coal are required to make 20,000 tons of excellent coke. The large coal is shipped mainly for locomotive use.

Mining in this district is for the most part easy, though at times only fair. Rock rolls and clay veins have interfered with mining in parts of these fields. The use of machines is limited somewhat by the local tenderness of the roof. The machines commonly used are the Harrison, Ingersoll, and Sullivan. Entries in this district are usually 10 feet wide, the rooms 18 to 21 feet, and room pillars 18 to 20 feet. Except the Eleanora and Elk Run shafts, the openings are either drifts or slopes. Capell fans are largely used for ventilation. Most of the mines are troubled with gas. The mines north and northeast of Punxsutawney drain to the Elk Run shaft, in the center of the basin, where the water is pumped to the surface by Cameron, Snow, and Gordon pumps. Both electricity and rope are used for haulage in this district, 2-ton cars being in common use.

The output of the Canoe Ridge mine of the Clearfield Bituminous Coal Corporation at Rossiter is from 2,800 to 3,000 tons daily, most of which goes to the locomotives of the New York Central, Boston and Albany, and Baltimore and Ohio railroads. Robinson and Stein fans are used here. Haulage is by electricity in 1-ton cars. Entries are 9 feet, rooms 21 feet wide, and room pillars 30 feet thick. In 1905 the Buffalo and Susquehanna Coal Company was opening a shaft near Big Run and preparing to operate on an extensive scale. The Jefferson and Clearfield Coal and Iron Company and the Berwind-White Coal Mining Company have each large operations in this field, but outside the limits of the Punxsutawney quadrangle. There are a limited number of smaller operations in this field.

In the Glen Campbell area the mines are uniformly smaller, having a daily output of from 50 to 250 tons, a few exceeding the latter figure. Mines in this district are fairly well equipped, several of them using electric haulage and machines for mining. Furnaces are used in some of the mines for ventilation. 


\section{COAL IN SANPETE COUNTY, JTAH.}

\section{By G. B. Richardsol \\ INTRODUCTION}

The report of the State mine inspector for 1904 credits Sanpete County with a production of 6,033 tons of coal, out of $1,563,274$ tons mined in U,ah. This small amount is furnished by two mines - one near Wales, which supplied only 00 tons, and the other near Sterling. Though the production of Sanpete County is smal, the occurrence of coal there is 'perhaps of more than local interest. Wales claims the distinetion of having produced the first coal mined in Utah. Coal is reported to have been diseovered there in 1857, and in 1862 this pioneer coal field of Utah was opened. In the early seventies a railroad was constructed from Nephi to Wales, and for a time the coal was taken to Salt Lake City. The Wales coal is of interest because of the unusual occurrence of the deposit immediately between two beds of limestone of Tertiary age, while the Sterling coal is an isolated deposit of Laramie (?) age occurring in a narrow fault block.

Sanpete County is situated in the central part of the State, in the plateau country immediately southeast of the termination of the Wasatch Range at Mount Nebo (see Pl. VIII). San Pitch River, the chief northern branch of the Sevier, occupies a broad valley in the center of the county. The mean altitude of the valley is about 5,200 feet, above which the Wasateh Plateau rises 6,000 feet on the east, while the lower Gunnison Plateau limits the valley on the west. Sanpete County lies just west of Carbon County, which produces most of the coal mined in the State.

\section{GENERAL GEOLOGY.}

The plateaus of this part of Utah are underlain chiefly by strata of Mesozoic and Tertiary age, which, except along lines of upheaval, where frequently the beds are sharply tilted, lie flat or only gently inclined. The rocks containing the coals are of Tertiary and Cretaceous age and the valley is occupied by unconsolidated Quaternary deposits. This area is included in the map of the Wheeler Survey $a$ and lies immediately north of the region studied by Dutton. $b$

Structure. - Sanpete Valley occupies a north-south structural trough, which separates the Gunnison and Wasatch plateaus. On the western side of the valley a well-defined fault extends along the base of the Gunnison Plateau, the scarp of which rises abruptly above the valley, exposing cross-sections of low, westward-dipping Tertiary strata. Locally the presence of the fault is accentuated by a narrow belt of Mesozoic (?) rocks dipping steeply eastward at the base of the plateau. On the east a monocline of large proportions is well developed. The rocks at the summit of the Wasatch Plateau lie almost flat, but toward the western rim the dip is low to the west and along the flanks increases to $10^{\circ}$ or $15^{\circ}$, constituting a dip slope which causes the strata that outcrop on the summit to pass beneath the valley filling. The monocline is broken by several parallel, north-south, normal faults of small dimensions. South of Manti other and larger faults are developed west of the monocline. The Sterling coal lies in one of these fault blocks.

$a$ U. S. Geog. Surv. W. 100th Mer., Atlas.

$b$ Dutton, C. E., Geology of the High Plateaus of Utah, U. S. Geog. and Geol. Surv. Rocky Mt. Region, 1880. 


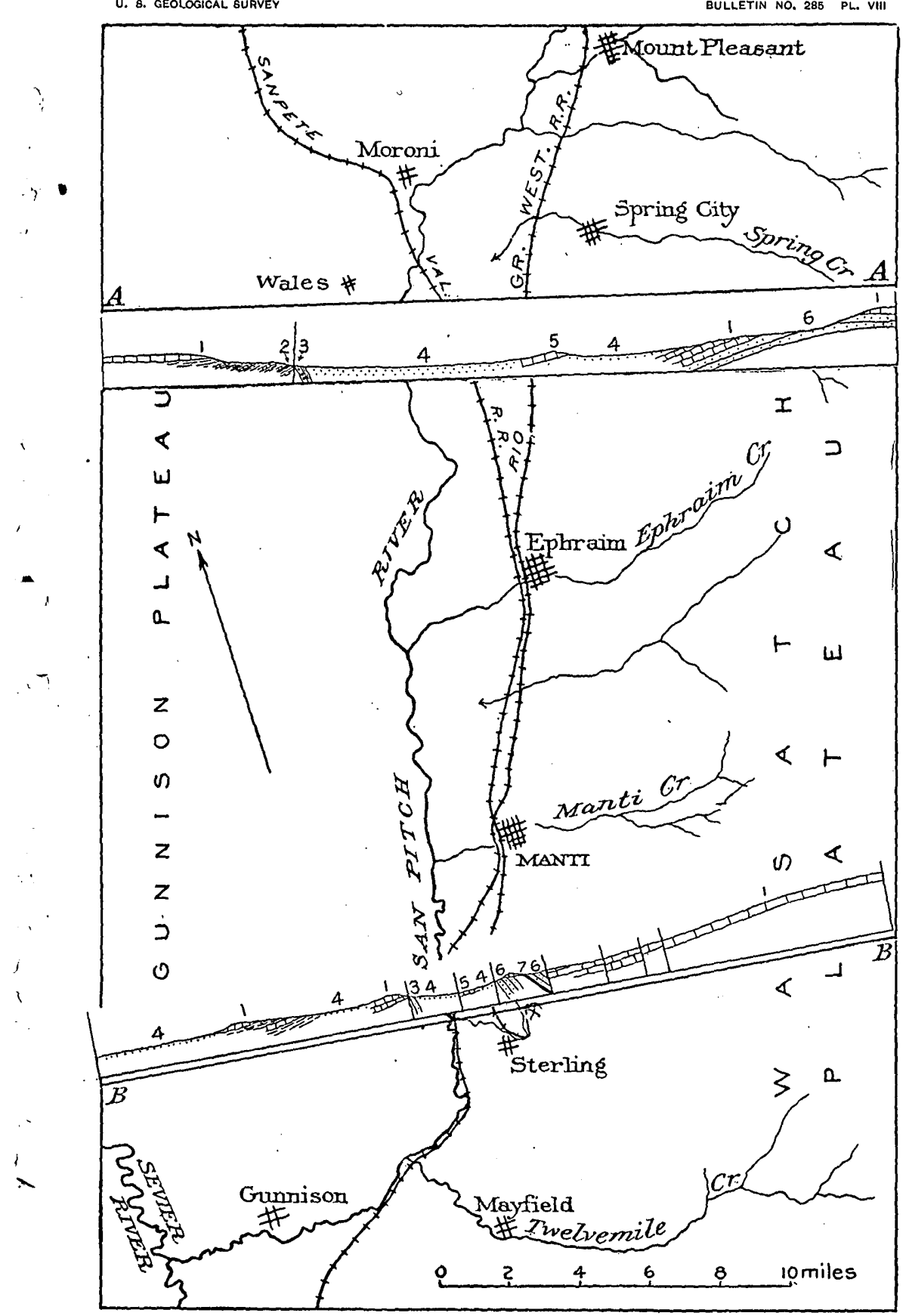

SKETCH MAP OF PART OF SANPETE VALLEY, ÚTAH, SHOWING SECTIONS ACROSS THE WALES AND STERLING COAL BEDS.

1, Eocene; 2, coal; 3, Mesozoic; 4, Pleistocene; 5, Manti beds; 6, Laramie; 7; coal. 

strata \& the Gunnison Plateau. No fossils have been found in the conglomerate, but on litblogic grounds it is provisionally correlated with the great mass of conglomerate west of tie Sanpete-Sevier Valley which underlies Eocene and unconformably overlies Paleozic strata. Its age is probably Mesozoic and possibly may prove to be Cretaceous. This conglomerate is unimportant so far as the coal to be described is concerned.

The coal-bearing Cretaceous rocks of Carbon County outcrop along the eastern scarp of the Wasatch Plateau and are conformably overlain by a considerable but unmeasured thickness of massive buff sandstones which locally cap the plateau, and outcrop in the valleys of the creeks that have cut deeply into its western flanks. This sandstone on the Wasatch Plateau is overlain apparently conformably by fresh-water deposits of Eocene age, but different sections show such variable conditions at the base of the known Tertiary that true conformity in the sense of $\Omega$ succession of widespread; uniform, uninterrupted deposits does not exist. In the vicinity of Sterling there is a distinct unconformity marked by flat-lying Tertiary beds resting on highly inclined sandstones, but here the sandstone is separated from the main mass on the plateau by faulting, and, though probably the same, it is not certain that they are one and the same bed. A few fragments of leaves too obscure for identification are the only fossils that have been found in this sandstone on the plateau, but in the sandstone of the fault block in which the Sterling coal occurs a number of plants have been found, among which F. H. Knowlton recognizes Sabal (?) cf. Sabalites Grayanus, Asimina eocenica (?) -Lesq., and Salix sp. (?), from which he concludes that their age is probably Laramie.

Tertiary rocks cover the greater part of the area here considered. They outcrop on the ummit and western flanks of the Wasatch Plateau and occupy much of the summit and eastern part of the Gunnison Plateau, and also form low ridges in Sanpete Valley. These Tertiary beds are light colored, consisting of drab or locally red shales, with interbedded thin limestone and sandstone layers, and massive, fine-textured, light-gray limestone that weathers white. The stratigraphy is characteristically varied, even adjacent sections being rarely alike. The thickness of the beds is at least 2,000 feet. Numerous fresh-water genera, including Sphrerium, Planorbis, Physa, Goniobasis, and Vivipara, identified by W. H. Dall, occur in these rocks, which are referred to the Wasatch stage of the Eocene.

The Tertiary sediments in the ridges in Sanpete Valley, referred to above, dip slightly to the west and aire separated from the Wasatch beds just described by Quaternary depnsits. The rocks of the valley uhdoubtedly are younger than those on theplateau, but whether they conformably overlie the Wasatch strata was not determined. Cope a named them the Manti beds and considered their age to be Middle Eocene, corresponding with the Wind River stage. They contain well-preserved specimens of fishes, turtles, etc.

Sanpete Velley is underlain by a considerable but unknown thickness of gravel, sand, and clay, derived from the adjacent highlands and deposited to a large extent at least under subaerial conditions. This valley filling is more than 600 feet thick, as shown by a well near Ephraim.

\section{COAL.}

Wales coal.-The Wales coal mine is in Wales or New Canyon, about 2 miles west of the town of Wales, at the foot of the Gunnison Plateau. The coal occurs near the base of the Eocene there exposed, where the following generalized section of Wasatch beds was obtained: 
Generalized section of Wasatch beds in Gunnison Plateau, at

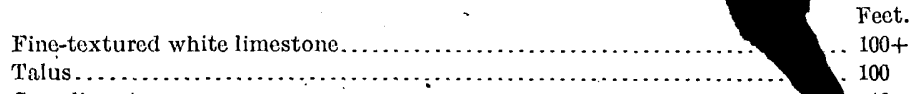

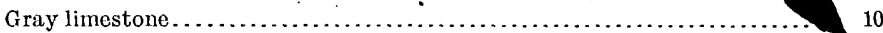

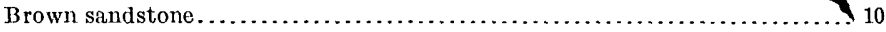

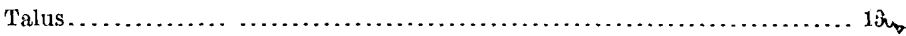

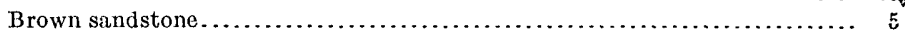

Drab limestone. . . . . . . . . 15

Brown sandstone................................................... 10

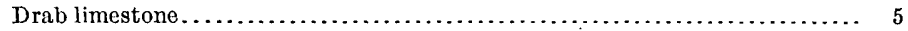

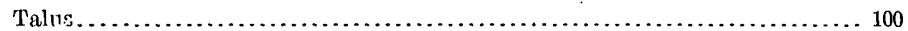

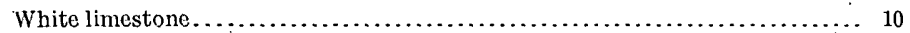

Drab shale.................................................. 50

Buff limestone. : .................................................... 15

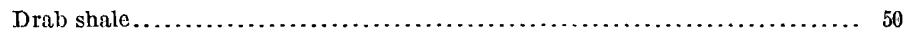

Talus....................................................... 150

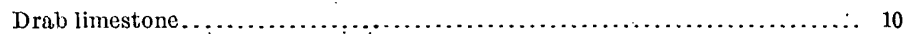

Drab shale, with streaks of purple shale ........................... 150

Brown sandstone................................................. 20

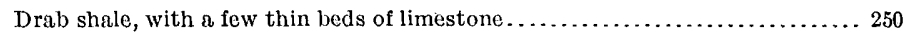

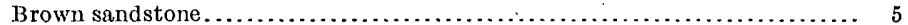

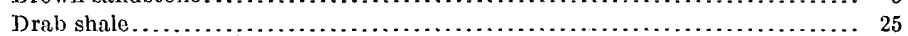

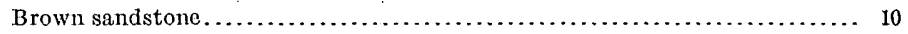

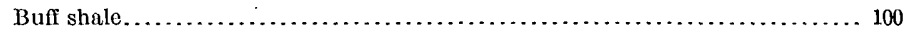

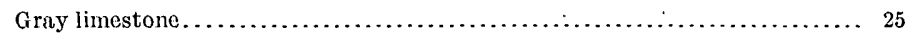

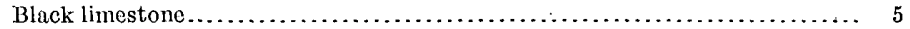

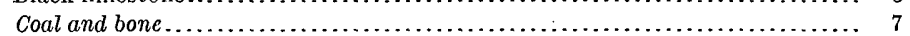

Black limestone................................................ 10

Dark shale.................................................. 15

Brown sandstone........................................................ 10

Drab shale .................................................... 10

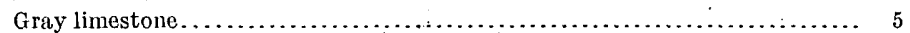

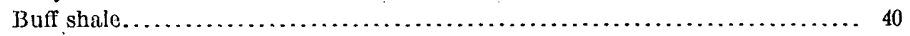

Sandstone . . . . . . . . 10

A notable feature of the section is the occurrence of coal immediately between beds of limestone. The limestone itself is black and bituminous and contains abundant crushed shells, including indeterminable species of the fresh-water genera Sphærium and Physa. At the entrance to the mine, on the outcrop, the following section is exposed:

Section at entrance to Wales coal mine.
7. Limestone.
6. Coal and bituminous limestone
Inches.

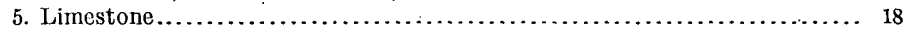
4. Coal including streaks of bone................................... 36

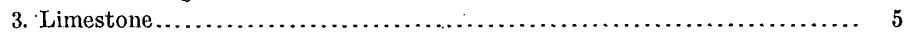

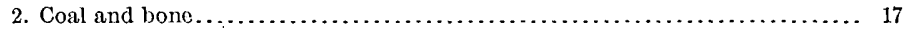
1. Limestone.

No. 2 of this section is rejected. A detailed measurement of No. 4, made in the mine, follows:

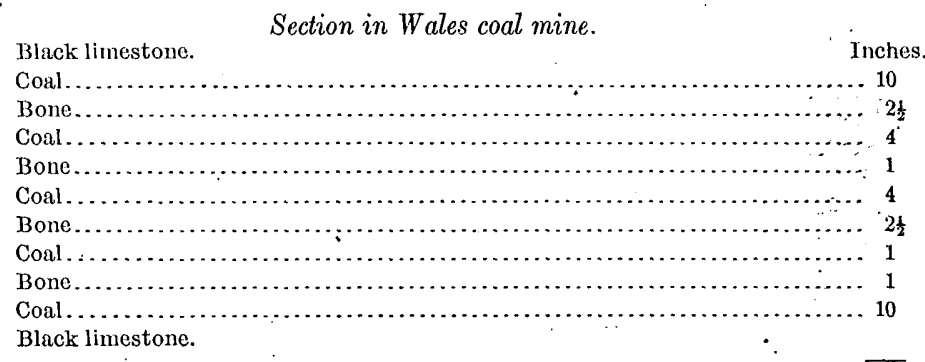


d in the mine by crosscutting the seam was sent in a sealed can to cological Survey coal-testing plant at St. Louis and analyzed, under N. W. Ivid, by F. M. Stanton, with the following results:

Analysis of cual from Wales mine.

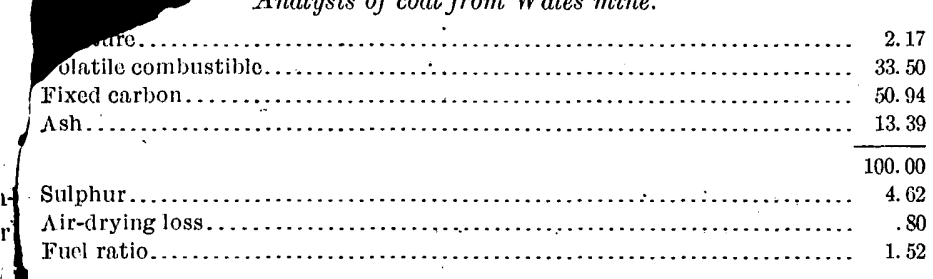

Th. coal has a lower percentage of volatile matter and a greater amount of fixed carbon, d consequently a higher fuel ratio, than the Carbon County coals, but its higher cor as ash and sulphur makes it generally less desirable. The coal is ton thin and bony to make it very valuable, yet it is used locally for domestic purposes and sells at $\$ 2.50$ a tón for lump, and $\$ 1.80$ a ton for fine coal, in competition with the Carbon County product brought to the valley by the Rio Grande Western Railway. The coal has a local reputation for blacksmith's purposes.

The Wales mine is opened on the outcrop and the workings extend about 200 yards along the strik. The coal in the mine dips S. $50^{\circ} \mathrm{W}$., magnetic $15^{\circ}$. The mine was dry when visited in August and the operator reported no trouble from water. Apparently the limestone roof is largely responsible for this condition.

This conl can be traced up the hillside north of Wales Canyon for a distance of about 2 miles, where it thins out. To the south it is reported to have been traced somewhat farther, but on account of the varying stratigraphy it is difficult to follow any particular stratum. The development of this mine is comparatively recent. The early workings were in a canyon to the south, but these have long been abandoned. A number of coal prospects occur at different places in the Gunnison Plateau and it is probable that more conl will be found in this vicinity, but it is not likely that much better results will be obtained.

Sterling coal.-Whe Sterling coal, developed by the Sterling Coal and Coke Company, at the Morrison mine, on Sixmile Creek about 2 miles east of Sterling, is more important than the Wales deposit. The mine is at the southern terminus of the Sanpete Valley Railway. It produced 5,633 tons.in 1904.

As already mentioned, the Sterling coal occurs in sandstone of probable Laramie age, in a fault block at the base of the Wasatch Plateau. There are several beds of conl, but only the lower ones could be measured when the mine was visited, September, 1905. The following section was furnished by H. R. Thomas, the former owner of the refing:

Section in the Morrison coal mine.

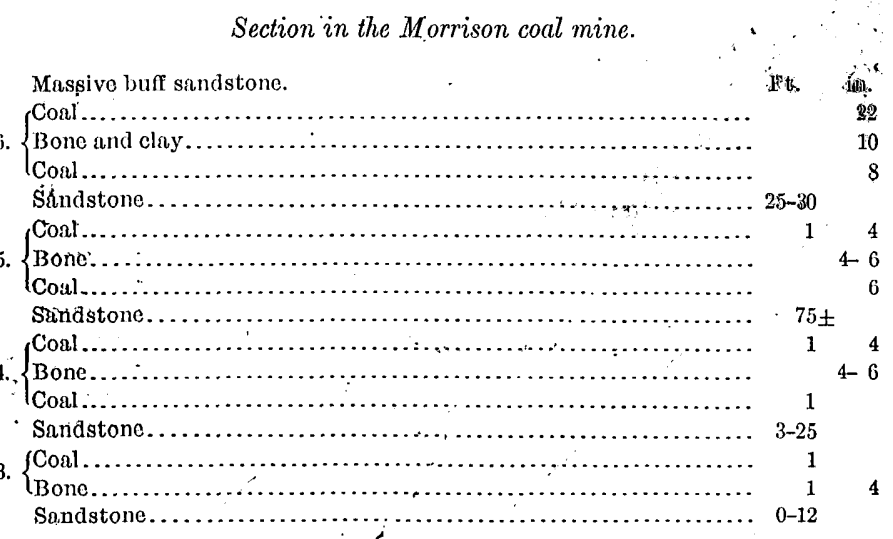


2 .

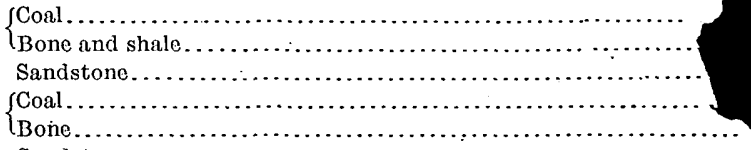

Coal No. 2 is the most important, and locally a bed approximating 4 feet in thickness. is formed by the coalescing of Nos. 2 and 3 and the pinching out of the intervening sandstone. The coal is lustrous black. It is much jointed in many directions and breaks easily into small pieces. The principal joints occur in two sets, east-west and nort suci.', corresponding to the jointing in the adjacent rocks. Thin films of calcium ca conate occur along the joints and small patches of rosin are disseminated through the cos The ease with which the coal breaks impairs its value, as it results in a large amoun of fine coal when it is mined.

A sample of bed No. 2 was collected in the mine by crosscutting the seam with the of obtaining an average and was sent in a sealed can to the laboratory of the United States Geological Survey coal-testing plant at St. Louis, Mo., where it was analyzed by F. M. Stanton with the following results:

Analysis of coal from bed No. 2, Morrison mine.

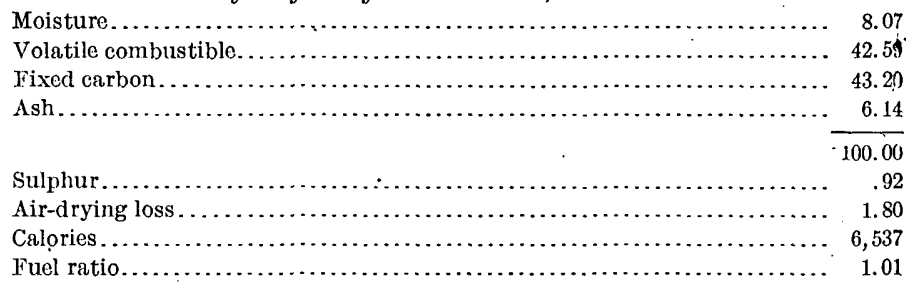

This is a bituminous coal having a somewhat high amount of volatile combustible matter and therefore a low fuel ratio. The percentage of moisture is rather high and the sulphur is low. At the mine it is reported that the coal will not coke. To judge from the analysis, the Sterling coal is similar to that mined in Carbon County.

Coal was long known to occur in this vicinity, but it was not developed until 1888, when an opening was made on the outcrop above the present workings. About 1894 the railroad was extended to the mine and the coal worked in a slope until so much trouble was caused by water that the mine was abandoned and the present tunnel was made. The mouth of the tunnel is on the hillside along the east bank of Sixmile Creek. It was driven through buff sandstone and thin beds of shale until the coal was struck at a distance of about 2,000 feet. The coal dips from $15^{\circ}$ to $20^{\circ} \mathrm{E}$.

A copions amount of water has been encountered in this mine, but it is easily drained and the water is transported in a ditch to Manti; a distance of about 6 miles. The water right is a valuable asset. August 17, 1905, the discharge at the mouth of the tunnel was found by C. S. Jarvis to be 5.6 second-feet. It is likely that the water is associated with the fault east of the mine. It probably comes from the westward-dipping sandstone of the plateau region to the east and, being under hydrostatic pressure, rises when it reaches the fault plane. There are a number of strong springs associated with faults in this general region.

The fault plane has not yet been reached in the workings. When it is the coal will be found to be cut off abruptly and its further continuation must be sought by sinking. How far down can not be told, for there is no measure of the throw of the fault

Other occurrences of this coal are linitted to the region between Manti and Sterling, for north of Manti the associated strata have beez eroded and south of Sterling they are covered by Tertiary beds. The best coal appears to be confined to the area already exploited and seems to be a local deposit. Only thin beds have been found in the valleys immediately north and south of the present workings. 


\title{
NOTES ON THE WEBER RIVER COAL FIELD, UTAH.
}

\author{
By Joseph A. TafF.
}

\section{PRELIMINARY STATEMENT.}

For many years coal has been worked with varying profit at a number of localities in We!... River Valley and its tributaries, Chalk and Grass creeks, in the vicinity of Coalville, Suımit County, Utah. Summit County is in northern Utah and adjoins southwestern Wyoming.

The Weber River coal field is situated east of the Wasatch Mountain range. The river collects its waters chiefly from the northwestern slopes of the Uinta Range, flows northward across Summit County, and thence westward through the Wasatch Range to Great Salt Lake west of Ogden.

Facilities of transportation for the coal of the Weber field are afforded by the Union Pacific Railroad. The main line of this road follows the valley of Weber River from Ogden to Echo, where it turns toward the northeast up Echo Canyon. From Echo the Park City branch of the Union Pacific continues up the Weber Valley through Coalville. From the Park City branch spurs have been constructed to the Wasatch and Grass Valley mines, 2 and 7 miles, respectively, northeast of Coalville. The Dexter mine, the only other one now in operation, is situated 1 mile southeast of Coalville.

The rocks at Coalville were examined and the occurrence of coal noted $a$ by F. B. Meck and E. Englemann in 1859 while attached to the exploring party in command of Capt. J. S. Simpson, U. S. Army. Meek revisited the field in 1872 and it was later studied by members of the Fortieth Parallel Survey; also by C. A. White in 1877. Beginning with the Meek and Englemann report in 1860, the rocks were classed in various groups of the Cretaceous: T. W. Stanton has surveyed the.Coalville section, besides various others in the western Cretaceous areas. In a comparative study $b$ of the Colorado group of the Cretaceous, the coal-bearing rocks of Weber River Valley are included by Stanton in the lower or Bentou division of the Colorado group.

The Weber River coal strata are of the same age as a part of those of the Kemmerer field in southwestern Wyoming, recently surveyed by A. C. Veatch. The exact stratigraphic correlation of the coal beds in the two fields, however, has not been determined.

\section{SURFACE FEATURES.}

The larger physiographic features of the country in the region of Coalville are not dependent for their expression on the lithologic character of the formations. The main valleys and ridges cut indiscriminately across the hard and soft rocks. Weber River has a course west of north and Chalk Creek runs nearly west, while the strike of the rocks is generally northeast and southwest. Within a range of 6 miles from Coalville the surface rises 3,500 feet toward the southwest. Toward the east and northwest it rises to elevations of 2,000 and 2,500 feet above the valley of Weber River, which is here 5,600 feet above the sea.

The thicker and harder sandstones of the coal-bearing section, Nos. 1, 4, and 6, given below, and another referred to near the top of the Cretaceous system in this field make distinctive ridges and benches in the lower slopes of the valleys of Weber River and Chalk 
and Grass creeks. The dip of the rocks is toward the northwest and the outcropping edges of these sandstones make precipitous southenstward-facing cliffs. The lowest sandstone, No. 1 of the section, is less prominent in its topographic effects than the others, yet is a distinct marker for the position of the most valuable coal bed in the field, which lies immediately beneath it.

\section{STRATIGRAPHY.}

The rock formations consist of shale, sandstone, and conglomerate, with occasional strata of limestone and three or more beds of coal. The numerous faults that intersect the rocks and the spaces of concealed strata in the valleys prevent the measurement of an accurate section in the-vicinity of Coalville except by a detailed survey and a careful study of the fossils. Little note was taken of the rocks below the lowest known workable coal now being developed at the Wasatch mine, 2 miles northeast of Coalville. Stanton, who has studied the section at Coalville, reports $a$ that below this coal are 500 to 600 feet of interstratified shale and sandstone. The following general estimated section, based in part on Stanton's measurements, in ascending order, will give some idea of the lithologic succession and positions of the coal beds:

\section{General section of coal-bearing rocks in Weber River field.}

Feet.

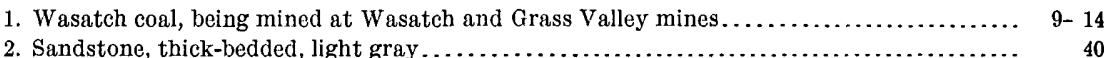
This sandstone is the roof of coal in Wasatch and Grass Valley mines.

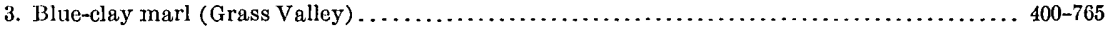

Crops in valleys chiefly and is usually only partially exposed. Coal occurs in the upper part or probably at the top of this shale. It is reported by Mr. Samuel Clark, superintendent of the Wasatch mine, to be a double seam, each bench being 3 to 4 feet and separated by 2 to 3 feet of shale. The upper coal is succeeded by sandstone.

4. Sandstone and conglomerate................................................ $100-300$

In Grass Valley it appears thicker than at Coalville. and is separated into two members by shaly strata.

5. Shale and thin sandstone.

$\mathrm{A}$ bed of shell limestone occurs in upper part and a thin bed of coal is reported to occur near the same position in the section. A coal in the upper part of this group of strata, once mined 2 miles southwest of Coalville, is reported by Mr. T. J. Lewis, manager of the Wasatch mine, to consist of two beds, each 2 to 3 feet thick, separated by shale varying in thickness from $1 \frac{1}{2}$ to 2 feet.

6. Massive light-yellow sandstone and conglomerate . . . . . . . . . . . . . . Above these sandstones and conglomerates there is shale, probably 1,500 feet thick, which is in turn followed by brown and gray sandstone, with minor shale beds, 1,300 to 1,500 feet thick, to the base of the great Wasatch conglomerate of presumably Tertiary age.

\section{STRUCTURE.}

The coal-bearing rocks in the vicinity of Coalville on the north and west are tilted toward the northwest at angles varying generally between $16^{\circ}$ and $20^{\circ}$. The rocks also have been broken and disturbed by two systems of faults. One is a system of strike faults bearing northeast and southwest, almost with the strike of the rocks. The other is a system of dip faults at right angles to the first. A fault belonging to the first-mentioned system may be seen northeast of Coalville. It extends from the northern boundary of the.city northeastward across the SE. $\frac{1}{4}$ sec. 4 and the NW. $\frac{1}{4}$ sec. 3 , T. 2 N., R. 5 E. The abandoned coal mine in the SE. $\frac{1}{4}$ sec. 4 is located near this fault. The rocks on the southeast side of the fault have been dropped with respect to those on the opposite side. The massive sandstone in the ridge lying across sec. 3 above and northwest of the Wasatch mine has been thrown down until it appears to extend 800 feet beneath its counterpart in the prominent ridge one-half mile to the northwest, extending across sec. 4 . A dip fault cuts the rocks crossing near the southwest corner of sec. 3 . Another fault of this system occurs 
nearly 3,000 feet northeast of the Wasatch mine. It crosses the township line near the center of the north side of sec. 3, T. 2 N., R. 5 E. This fault has limited operations in the Wasatch mine toward the north. Minor faulting and belts of fractured strata are found frequently in the mines.

In Dexter Hollow and at the Dexter mine, 1 mile southeast of Coalville, the rocks dip $16^{\circ} \mathrm{SE}$. Between Dexter Hollow and Spring Canyon, 1 and 2 miles, respectively, southsoutheast of Coalville, the dips are eastward. As Spring Canyon is ascended eastward 2 miles from Weber River Valley, the rocks are seen to dip successively northward and then northwestward. These observations indicate that a basin-like fold bears eastward from Weber River Valley in the central part of T. 2 N., R. 5 E. Between this fold and the northwesterly dipping rocks at Coalville the structure is anticlinal and the rocks are probably faulted. Exposures of the rocks are insufficient, however, to reveal the character of the structure.

\section{COAL.}

There are certainly three and probably four coal beds mined or prospected in the region of Coalville. These coals will be considered in the order of stratigraphic succession and, as it happens, at the same time in the order of economic importance.

Wasatch coal.-The first of these coals may be called the Wasatch coal, from the Wasatch mine, now in operation, 2 miles northeast of Coalville. The coal here has been removed from an area 4,000 feet on the strike by 750 feet in the direction of the dip. The conl is massive, and varies in thickness between 9 and 14 feet. A sandstone bed 40 feet thick forms the roof. The floor is a dense clay, and is underlain by a bed of bony coal, the thickness of which has not been determined. The coal mines in block, is moderately hard, and appears to be a fair grade of the bituminous variety. In the proximity of faults and zones of shearing that are of common occurrence the coal has suffered considerable crushing. In such places it is rendered weak and considerable slack and soft coal is produced.

The same coal is mined on Grass Creek, 7 miles northeast of Coalville, in sec. 18, T. 3 N., R. 6 E. The Grass Creek coal is the same bed as that of the Wasatch mine. Massive sandstone 40 feet thick overlies it. The coal is usually 8 feet thick, but swells locally to 12 feet. In this mine, as in the Wasatch, the coal is much jointed and broken by faults. Water enters the mine freely through the joints and fault fissures, requiring constant pumping. Because of excessive water the pillars are being drawn in the mine preparatory to moving operations one-fourth mile to the southwest.

The outcrop of the same coul follows Grass Creek, and has been mined at a number of localities down the valley, from sec. 18 , T. 3 N., R. 6 E., to sec. 27 , T. 3 N., R. 5 E., where it is interrupted by a dip fault which displaces the outcrop of the coal toward the southeast. The coal has been mined at seven or more places along Grass Valley within a distance of 4 miles below the Grass Valley mine, but all have been abandoned. The Union Pacific Railroad was the chief operator, but it is reported to have abandoned the work here in favor of better property in the Wyoming field. The 'Wasatch coal was mined also in the town of Coalville and for a time a mile northwest of town near the strike fault, but these operations have been abandoned.

Dexter coal. - A coal bed is being developed by the Dexter Brothers, 1 mile southeast of Coalville, in the SE. $\frac{1}{4}$ sec. 16 , T. 2 N., R. 5 E. It is presumed by some that this bed is the same as the Wasatch coal, but the identity of the two beds is not proved by surface indications. The section at the Dexter mine seems to be as follows:

\section{Section at Dexter mine, 1 mile southeast of Coalville, Utah.}


The upper bench of coal is the only one now worked. The section below this bench is reported by Dexter Brothers to have been proved by excavations beneath the present workings. The coal in the Dexter mine is clear of shaly impurities or tangible sulphur compounds, and the quality appears to be equal to that of the Wasatch coal. The Dexter coal has been mined to a small extent in several places in the hollow below the Dexter mine. The irregularities in the position of the outcrops, as indicated by the abandoned mines and the difficulties said to have been encountered in mining shows that the strata have suffered considerable displacement by faulting.

Other coals.-A double coal bed occurs nearly 400 feet above the Wasatch coal, but is, at the present time, of little economic importance. The coal in each of the two benches is reliably reported to have been mined a mile north of Coalville. Each bench is 3 to 4 feet thick, separated by a shale bed 2 to 3 feet thick. A coal in the stratigraphic position of this bed has been prospected in the north slopes of Grass Creek Valley near the south side of sec. 3 , T. 3 N., R. 5 E. A similar double seam of coal occurs stratigraphically about 700 feet higher and 1,100 to 1,200 feet above the Wasatch coal. In the early development of the country this coal was mined 2 miles west of Coalville, in sec. 19, T. 2 N., R. 5 E. It is reliably reported that each of the beds is $2 \frac{1}{2}$ to 3 feet thick and separated by $1 \frac{1}{2}$ to 2 feet of shale. A coal in the same stratigraphic position was mined also at one time in the NW. $\frac{1}{4}$ sec. 4 , T. 2 N., R. 5 E.

Quality of the coal.-The Wasatch, Grass Valley, and Dexter mines now in operation in the vicinity of Coalville yield a product that has the physical properties of a fair-grade bituminous coal. It is a black block coal of medium hardness. A sample of the Wasatch coal was analyzed by Mr. F. M. Stanton, chemist, U. S. Geological Survey coal-testing plant, St.Louis, Mo. An analysis of the coal at Winterquarters, one of the most extensive mines in the Book Cliffs coal field, was made also. The Book Cliffs field is the most extensive in the State, and the coal has been successfully used both for steaming and domestic purposes and in the production of coke.

Comparative analyses of coal from Coalville and Winterquarters.

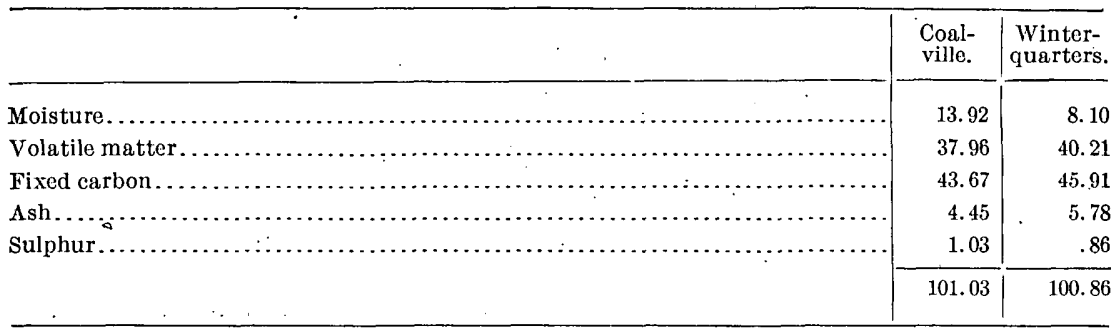

The percentage of water in the Coalville coal approaches that often found in the black lignites, the highest grade of so-called lignites. Owing to the abundant mine water occurring in the mines near Coalville and the shattered character of much of the coal, it is possible that a small amount of superficial water was carried in the sample at the time the analysis. was made. The physical characteristics, its behavior on exposure in the atmosphere, and its utilization show it to be a bituminous coal well adapted to domestic uses.

Conclusion.-The coals of the Weber River field, other than the Wasatch and Dexter. beds, are of little immediate economic value. The interstratified shales, together with the difficulties experienced in mining incident to water and broken strata, have prevented these other beds from competing with the Wasatch and Dexter coals. The Wasatch and Dexter beds are ample in thickness for successful working, and the quality of the product compares favorably with the better grades of bituminous coals of the Rocky Mountain region. The difficulties in the way of large exploitation of these coals are the amount of mine water and the fractured nature of the beds, resulting in the production of considerable quantities of slack. 


\title{
BOOK CLIFFS COAL FIELD, UTAH, WEST OF GREEN RIVER.
}

\author{
By Joseph A. TAFF.
}

\section{LOCATION AND EXTENT.}

The Book Cliffs coal field is in central and eastern Utah. Its south end lies in eastern Sevier County, near the center of the State. From this locality the field bears northnortheast to Price River near Castlegate, in wesiern Carbon County. From Price River it curves to the east for 20 miles and then bears to the southenst, crossing Green River north of the Rio Grande Western Railway. Beyond Green River it turns to the east and northeast, passing into Grand County and thence into Colorado. Only that part of the field limited to Sevier, northwestern Emery, and Carbon counties has been surveyed and hence is included in this report.

The Book Cliffs conl field is relatively narrow, comprising the eastern escarpment of the Wasatch Plateau through Sevier, Emery, and western Carbon counties and the southern face of the Book Cliffs from Castlegate eastward to the Colorado line (see PI. IX). The lateral extent of the field is governed by the length and depth of the canyons that have been cut into these escarpments. A local variation in width may be noted in a north-south swell of the strata situated near the eastern rim of the Wasatch Plateau in extreme western Carbon and northwestern Emery counties. The mining towns of Clear Creek and Winterquarters are on the northward pitch of this swell. The erosion of Pleasant Valley and the upper part of Huntington Creek Valley have exposed the coals in this uplift. With the exception of Pleasant Valley the canyons cutting the coal-bearing rocks descend from the plateaus out through the faces of the escarpments into the rolling plain of Castle Valley.

The coal-bearing strata descend gradually inward beneath the plateaus from the middle slopes of the front cliffs and pass beneath the drainge line of the canyons and gulches, as a rule within a few miles of the front. Exceptions may be noted in the case of Price River, Huntington Creek, and Gordon, Cottonwood, Ferron, and Muddy Creek canyons, where the coal outcrops extend from 6 to 20 miles into the plateaus. In such instances the field of available coal is considerably increased.

\section{SURFACE FEATURES.}

The region of the Book Cliffs coal field is an open country, and from an eminence near the junction of the Wasatch escarpment and Book Cliffs north of Price the observer may comprehend the general physical features of the whole land at a single sweeping view. The desert plain of Castle Valley stretches away to the limit of vision toward the southwest and southeast. Between the arms of the valley toward the south the broad rugged surface of the San Rafael Swell rises in the distance. Along the borders of Castle Valley on the north and west terraced cliffs rise to heights of 1,500 to 2,000 feet. These form the escarpments of the Book Cliffs and the Wasatch Plateau. Between Castlegate and Sunnyside the Book Cliffs Plateau slopes gradually to the north, in agreement with the dip of the rocks to the base of the Roan Cliffs.

Long, tongue-like, flat table-lands and mesas 100 to 200 feet high, capped by the thick sheet of bowlder wash, the remnants of the old valley floor, extend from the bases of the Book Cliffs and Wasatch escarpments out into Castle Valley. At the borders of these table-lands and mesas are fantastically carved terraces and columns. The floor of Castle 
Valley and of the lower slopes of the escarpments at its borders is a friable blue-clay marl. The larger streams that flow from the plateaus have worn through the bowlder layer, forming flat box valleys in the soft clay marl. The smaller drainage channels on cutting through the bowlder and gravel surface sink deeply into the marl, producing an extremely rough, bowlder-strewn, badlands type of topography. Before this erosion occurred the old valley floor stood high above its present level and was covered with a thick mantle of bowlders and gravel, which was spread over the plain for several miles from the escarpments.

Beds of sandstone that are locally variable in thickness occur in the shale of Castle Valley 500 to 700 feet below the top of the formation. At the base of the Book Cliffs they are thin and shaly and have little effect on the topography. From Price River westward they increase in thickness rapidly, aggregating more than 100 feet on Gordon Creek. Toward the south they thin to mere bands on reaching Huntington Valley; but still farther south they become thicker, reaching 200 to 250 feet on Muddy and Ivie creeks at the south end of the coal field. These sandstones, occurring as they do in the midst of soft shales, make peculiar and striking features in the topography and from them Castle Valley has acquired its name. Box canyons, many of them impassable, fluted and terraced cliffs, castellated headlands, and perpendicular towers mark their occurrence. Even where the sandstone is thin it serves as a protecting cap to the buttes, and in many places the underlying clay marl stands in perpendicular columnar walls 100 feet or more in height. The soft layers in the marl weather out in parallel bands in the cliffs, leaving the hard layers as projecting ledges. Thus the cliffs simulate rows of gigantic books:

There is a gradual rise of the surface from Castle Valley toward the San Rafael Swell. The rocks beneath the Castle Valley marl consist of pinkish sandstone several hundred feet thick. This sandstone makes the Red Plateau and the western rim of the Swell. In turn, it is underlain by friable arenaceous shale. On cutting through the sandstone the streams have descended rapidly in the soft underlying marl, creating a strikingly rugged and almost impassable country, which extends diagonally across Emery County from the Red Plateau toward the southwest. The main escarpment produced by these sandstones faces east and-south toward the center of the Swell. Numerous channels draining into San Rafael River and Muddy Creek have cut by headwater sapping into this escarpment, reproducing in a measure the topography of the Book Cliffs and the Wasatch Plateau escarpments, with even more picturesque effect. Perpendicular cliffs mark the escarpment faces and deep box canyons extend back into the plateau. On the divides and projecting points between the drainage lines near the escarpments there are high pinnacles and rugged towers of pinkish sandstone.

\section{STRATIGRAPHY.}

The survey of the Book Cliffs field during the past season had special reference only to the occurrence of coal. Such work as could be devoted to formations contiguous to the coal-bearing rocks was in the nature of a reconnaissance.

The rocks are naturally arranged in thick groups of strata. In each group either sandstone or shale greatly predominates. They contain scant fossil remains, and sufficient information regarding their age has not been obtained to correlate them with similar well-known beds.in other parts of the country. The entire section is without doubt Cretaceous, and the principal coal-bearing strata are within the Laramie formation. Further study of the section and detailed areal mapping will doubtless show that the principal groups of strata may be subdivided into smaller units of more uniform lithologic character. For these reasons the formations will not be named, being described by reference to their occurrence.

Shale of the San Rafael Swell.-The lowest formation was noted in a reconnaissance down Muddy Creek southeast of Emery. Only the upper 250 to 300 feet of the formation was seen. It consists of bluish arenaceous shale. From the cliffs of overlying sandstone it could be seen that deposits of the same character make the desert 12 to 15 miles out on the western slopes of the San Rafael Swell. 


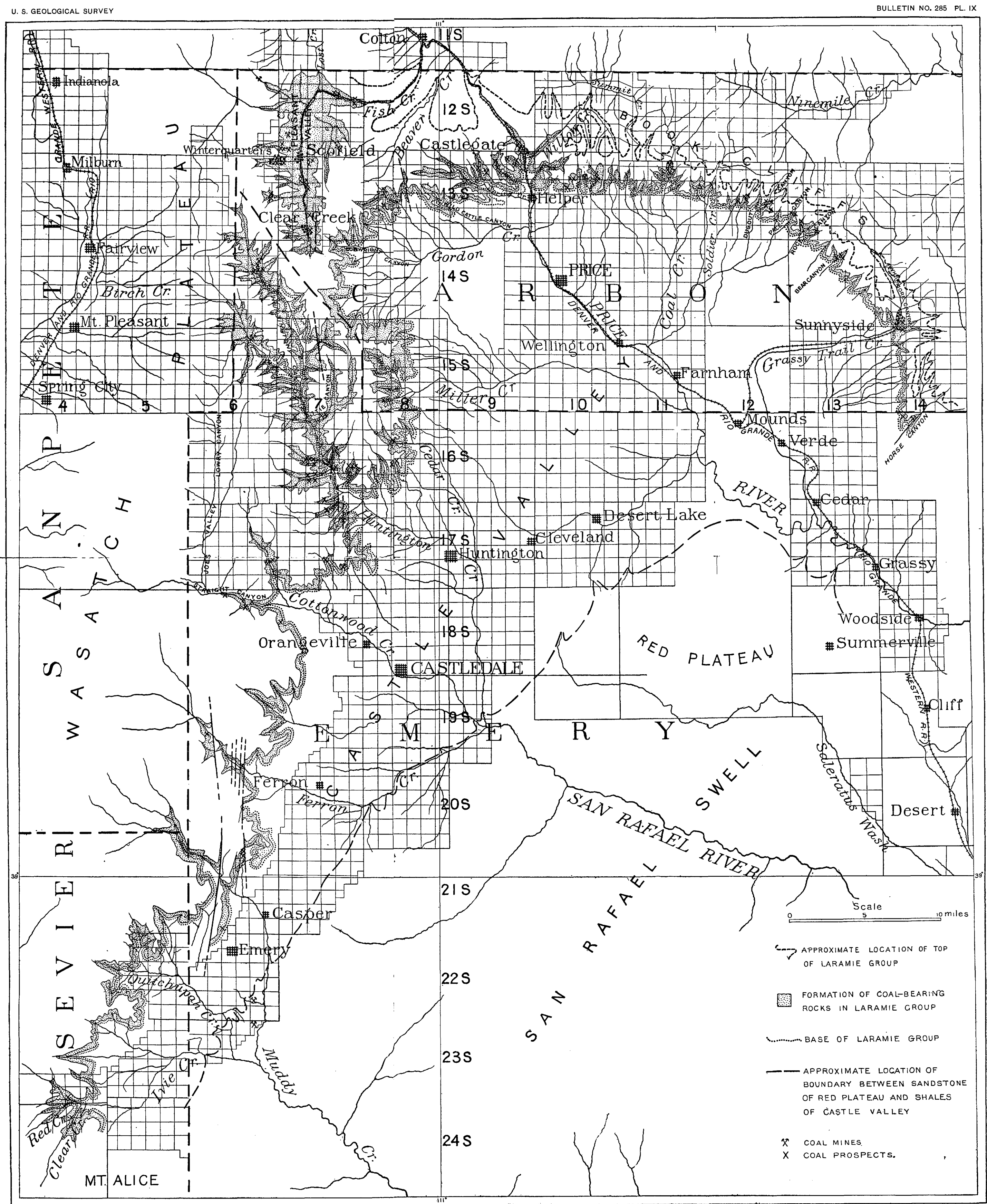

MAP OF BOOK CLIFFS COAL FIELD, WEST OF GREEN RIVER, UTAH, SHOWING OUTCROPS OF COAL-BEARING ROCKS. 
Sandstone of the Red Plateau.-Reddish, yellow, and brown sandstone overlies the blue shale of the San Rafael Swell. On Muddy Creek southeast of Emery, where the section was measured, the formation consists of sandstone, shale, and coal, in the following order, from the top down:

\section{Sectron on Muddy Creek.}

Base of Castle Valley shale.

Ft. in.

1. Brownish and yellow sandstone, with some shale interstratified ..... 25

2. Thin seam of coal.

3. Shaly sandstone.......................................... 10

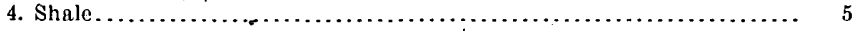

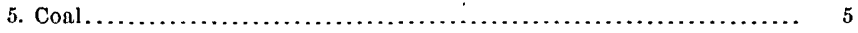

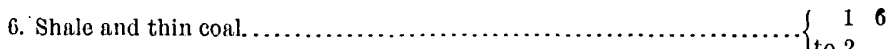

7. Yellow, brown, and pinkish sandstone....................... 125

8. Bony coal, separated into two nearly equal benches by variable bands of $\begin{cases}4 & 9\end{cases}$ bony shale 4 to 14 inches in thickness........................... to to 72

9. Yellowish sandstone..................................... 15

10. Bituminous shale and coal, the coul occurring in two bands of nearly equal thickness.......................................... 3

11. Yellow, somewhat friable sandstone, with thin carbonaceous shale in the central part............................................... 225

This sandstone formation makes the bold, rugged escarpment and the Red Plateau, bounding the San Rafael Swell on the northwest side and the north end, respectively. The escarpment grows higher and more rugged northward from Muddy Creek, and for this reason it is believed that the formation becomes thicker in the same direction. The coal, which is of little economic importance, is known to occur only to the east and southeast of Emery.

Shale of Castle Valley.-A blue-clay shale or marl 1,000 to 1,500 feet thick overlies the sandstone of the Red Plateau. Castle Valley is eroded in this shale; and the sandstone lentils in the upper part produce the characteristic topographic features from which the valley derived its name. The lower half of the formation lies in a gently undulating desert plain, and the rocks usually are not exposed. In the coal investigation there was no occasion to examine the lower part of the formation. The upper part, except the sandstone lentils, is an even-textured blue marl that is highly impregnated with alkaline salts. Even on rapidly weathering surfaces the white salts exude in many places. In poorly drained irrigated districts, where the soil is thin, alkaline salts are so abundant as to destroy vegetation. The sandstone lentils that occur 500 to 700 feet below the top are made up of beds of varying purity and thickness. From the vicinity of Sunnyside westward to Price River they are represented by thin shaly sandstone that is scarcely perceptible, having very slight effect on the topography. Westward from Price River the beds increase in thickness, aggregating more than 100 feet in the valley of Gordon Creek. Toward the south the beds thin out to mere bands in a distance of 13 miles. Southward from Huntington they increase again, reaching nearly 200 feet on Quitchupah and Ivie creeks, at the south end of the coal field. The sandstones comprising the lentils include many shaly sandstone and shale beds.

The Castle Valley shale was examined by T. W. Stanton in a brief reconnaissance trip near the Rio Grande Western Railway about 50 miles southeast of Castlegate. The collections of fossils that he was able to make showed that the upper part of the Castle Valley shale belongs to the Montana group of the Cretaceous and that the parting between this group and the succeeding Laramie coincides approximately with the boundary between this shale and the overlying sandstone of the Book Cliffs.

Laramie formation. - The Laramie formation consists of sandstone, shale, and coal in alternate succession. The sandstones occur in beds ranging from a few feet to nearly 500 feet in thickness. For convenience of description the Laramie formation may be separated into three parts-(1) that below the coal, consisting of sandstone and shale in almost equal proportions; (2) coal-bearing series of sandstone, shale, and coal alternately stratified; (3) upper beds, consisting almost entirely of sandstone.

1. The rocks below the coal consist of two thick yellowish to drab and light-gray sandstones separated by a mass of shale and thin sandstone. The lower sandstone varies in 
composition as well as thickness. In the Wasatch Plateau it is 80 feet or more thick and generally a massive magnesian sandstone. In the Book Cliffs it is thinner and more shaly. It is always present, however, and is exposed in steep bluffs and often impassable cliffs. This bed invariably overlies the marly shale formation of Castle Valley. Above the lower sandstone is a series of shale and sandstone beds. The sandstone rarely reaches a thickness of 20 feet, and the whole aggregates 60 to 100 feet. These beds are often talus covered. Where exposed they make rather steep terraced slopes, and the sandstone ledges project in benches or low bluffs. Beneath the lowest productive coal bed in the Book Cliffs field there is a continuous sandstone 80 to 100 feet thick. It is light yellow or drab in color except the upper 10 to 20 feet, which is usually white. In the eastern and southern slopes of the Book Cliffs and Wasatch escarpments the sandstone stands out in steep bluffs and often impassible cliffs. In the northern and western slopes of the canyons entering the escarpments it is often broken down, but is rarely concealed by talus. This sandstone bed is a most valuable guide in searching for coal in this region, as it occurs just below the lowest workable coal in the Book Cliffs field. It can not only be traced readily from point to point of the cliffs, but can be recognized at a range of several miles by its characteristic features and position.

2. The coal-bearing rocks consist of nearly equal portions of sandstone and shale, with several beds of coal. With the exception of some heavy beds in the lower part, the series consists of relatively thin strata that are usually more or less concealed by talus. The lowest coal bed where it has been seen fully exposed in mines and prospects varies between 3 and 20 feet in thickness. It rests often directly upon the massive sandstone at the top of the series below the coal. In the localities of its thinner occurrence blue to black shales, usually containing thin coals, occur above it. Where the coal bed is thickest it commonly has a sandstone roof.

Pinkish to yellow sandstone, associated with shale, overlies the lowest coal. These deposits, 30 to 50 feet thick, usually make steep slopes between cliffs of sandstone in the escarpments and canyons that face toward the south and east. In sec. 16, T. 13 S., R. 10 E., north of Price, they are succeeded by a second coal bed 8 feet 6 inches thick.

A massive sandstone overlies this second coal bed. It is yellow to pink in color, except the upper 15 to 20 feet, which is almost white. This sandstone, like that underlying the lowest coal, extends throughout the Book Cliffs field. Its thickness is rarely below 50 feet and sometimes approaches nearly 100 feet.

A third coal horizon occurs immediately above this sandstone in sec. $16, \mathrm{~T}$. $13 \mathrm{~S} ., \mathrm{R}$. $10 \mathrm{E}$., where the rocks are naturally displayed for inspection. Fifteen feet of coal were exposed. In Coal Canyon, in T. 13 S., R. 11 E., a coal in this position is 8 feet thick. A coal having approximately the same stratigraphic position in Huntington Canyon, in sec. 24 , T. 16 S., R. 7 E., is 8 feet thick. Above this third coal horizon there is a uniform succession of sandstone, shale, and coal, upward for 600 to 800 feet to the top of what is now recognized as the coal-bearing series. It, is not usual that the individual sandstone beds exceed 10 feet in thickness. Shales and sandy shales are usually concealed by o. It is estimated that the aggregate thickness of the shaly beds is nearly equal to that of the sandstones. Several coal beds, some of workable thickness, occur in this series of sandstones and shales. In the Book Cliffs north of Price, between Bull and Helper canyons, one bed occurs 50 feet and another 150 feet above the third coal horizon. In Coal Canyon six coal beds have been exposed in a section of rock 360 feet thick. The uppermost one, 4 feet 11 inches thick and of excellent quality, appears to be above the third coal horizon. In Huntington Canyon and in other places in the Wasatch Plateau coals of workable thickness are known to occur in the upper part of the coal-bearing series, but little attention has been paid to them where coals 4 to 20 feet thick occur lower in the section and are more accessible.

3. The coal-bearing series of shale, sandstone, and coal is succeeded by a formation of light-yellow sandstone that continues upward to the base of the Tertiary deposits in the crest of the Book Cliffs Plateau. Thin coal seams have been seen at a few places in the 
lower part of this section and some shale is interbedded with the sandstone in the upper part. The central 500 to 700 feet of this sandstone series make bold cliffs toward the top of the Book Cliffs and Wasatch escarpments. In the Book Cliffs the sandstone is estimated to be not less than 1,000 feet thick. Toward the west it either becomes thinner or is in part concealed by the overlap of Tertiary strata.

\section{STRUCTURE.}

That part of the Book Cliffs coal field west of Green River lies on the outer rim, to the north and west, of the broad upward fold known as the San Rafael Swell. The Book Cliffs are on the northward-pitching end of this fold and the rocks dip about $5^{\circ}$. Near the junction of the Book Cliffs and the eastern escarpment of the Wasatch Plateau, at the west side of Price River Valley, the strike of the rocks turns toward the south. Throughout the eastern escarpment of the Wasatch Plateau, from Price River to the south end of the field in eastern Sevier County, the rocks are almost flat. The dips are usually toward the west and rarely exceed $2^{\circ}$.

Folds.-Huntington Canyon and Pleasant Valley cuit deeply. into the northeastern part of the Wasatch Plateau, exposing the coals and revealing a slight upward flexure of the rocks. The strata have been broadly though slightly warped. The center of this swell is situated near the sources of Huntington Canyon and Pleasant Valley, in western Carbon and northwestern Emery counties. The swell is so low that the westward inclination of the strata due to the San Rafael uplift is succeeded by a horizontal position or one slightly inclined toward the east. The rocks are inclined at a lower grade southward down Huntington Canyon. The dips of the rocks, however, are less than the grade of the stream. The inclination of the strata is very low also toward the west. The dip is very slight toward the north from the head of Pleasant Valley to Scofield. From Scofield northeastward, however, the inclination gradually increases to about $5^{\circ}$ in the vicinity of Colton.

Faults.-A series of parallel normal faults, trending in a north-south direction, were noted toward the head of Pleasant Valley; also in Huntington Canyon in the eastern part of T. $16 \mathrm{~S} ., \mathrm{R} .7 \mathrm{E}$. The fault planes are nearly vertical and the throws or displacements vary from a few feet to nearly 100 feet. Coal prospectors report that greater faults occur on the west side of Pleasant Valley above Winterquarters, but the report was not verified. A few faults of local extent bearing east and west were noted in the Winterquarters mine, and associated with them are parallel thin igneous dikes that locally coke the coal. Another group of normal faults bearing north and south cut the escarpment of the Wasatch Platenu west of Ferron and Emery. In places the faulting is in a single plane, while in others it is compound, resulting in a series of steps or zone of shearing. The block or band of faulted strata west of Ferron and Emery varies from $1 \frac{1}{2}$ to 3 miles in width. The largest faults here are on the sides of the block, and the country between them has been depressed downward nearly 300 feet. The fault scarps facing the depressed block at the north side of Ferron Canyon are very pronounced. Conglomerate and shale of supposed Tertiary age occur on this downthrown block at lower elevations than the Laramie sandstone on either side. Several intermediate faults extending parallel to those on the side deform the downthrown block. Some of these minor fault blocks are tilted so that the beds dip as high as $20^{\circ}$.

\section{COALS.}

The workable coal beds that have been mined or prospected to any important extent are found in the lower 250 feet of the coal-bearing strata described above. These coals are associated with prominent sandstcne beds that can be recognized with ease and assurance by the prospector. They crop out in the lower cliffs and in the more accessible parts of the canyons and valleys.

Quality of the coal.-The workable coals in the Book Cliffs field, with a few exceptions in the thinner beds, have the same physical characteristics, though the beds range in 
thickness from 4 to 20 feet and in a few instances more than 20 feet. The coal is usually free from shaly impurities and is massive. So pronounced is the massive nature where the coal is fresh that seams or lines indicating stratification are scarcely discernible. It mines in irregular blocks, often of large size. A bed 15 to 20 feet thick is inclined to spall in large irregular slabs several feet in extent across the bedding. The coal is not usually affected nor does it slack to any appreciable extent on exposure to weathering agents. It is black and for the most part has a bright luster. It usually contains small irregular inclusions of a yellowish, brittle, resin-like bituminous substance scattered here and there that yields an asphaltic odor on ignition. The following proximate chemical analyses give a fair idea of the composition of the coals. The samples for analysis were collected from the several beds in the lower part of the coal-bearing section and from localities scattered between Huntington Canyon in the Wasatch Plateau and Horse Canyon, a point 60 miles distant in the Book Cliffs southeast of Sunnyside. The method of selecting samples of coal for analyses is as follows: A clean surface of the whole bed at the face of the working is selected, or a section of about 6 inches in width is made clean by removing the surface. Then a channel 3 to 4 inches in width and of even depth is cut down the cleaned surface, so that an equal amount of coal is obtained for each unit of a section. This coal so removed is placed on a clean surface and immediately broken to lumps half an inch and less in diameter and thoroughly mixed. The sample is then quartered, opposite quarters being taken and remixed. The quartering, selecting; and mixing process is continued until the sample is reduced to about 1 quart, which is placed in a galvanized-iron can, sealed, and shipped to the laboratory.

The Book Cliffs coals are clearly within the bituminous grade, and are remarkably uniform in composition. The sulphur content is also uniform and low, the average being a little above one-half of 1 per cent.

Proximate analyses of coals from the Book Cliffs coal field, Utah.a

\begin{tabular}{|c|c|c|c|c|c|c|c|}
\hline No. & Location. & Moisture. & $\begin{array}{l}\text { Volatile } \\
\text { matter. }\end{array}$ & $\begin{array}{c}\text { Fixed } \\
\text { carbon. }\end{array}$ & Ash. & Sulphur. & $\begin{array}{l}\text { Loss of } \\
\text { moisture } \\
\text { on air } \\
\text { drying. }\end{array}$ \\
\hline 1 & $\begin{array}{r}\text { Horse Canyon, sec. } 4(?), \text { T. } 16 \text { S., R. } \\
14 \mathrm{E} \ldots \ldots \ldots \ldots \ldots \ldots\end{array}$ & 4.76 & 38.16 & 52.09 & 4.99 & 0.74 & 1.00 \\
\hline 2 & Upper bed, No. 1 mine, Sunnyside.... & 3.37 & 38.04 & .52 .75 & 5.84 & .60 & 1.30 \\
\hline 3 & $\begin{array}{l}\text { Average of crushed coal, prepared for } \\
\text { coking, from all mines, Sunnyside:.. }\end{array}$ & 3.43 & 37.72 & 51.68 & 7.17 & .78 & 1.50 \\
\hline 4 & DugoutCanyon, sec.23,T.13S., R.12E. & 4.98 & 38.20 & 52.94 & 3.88 & .54 & 2.40 \\
\hline 5 & $\begin{array}{l}\text { Bean prospect, Coal Creek Canyon, } \\
\text { sec. 10, T. } 13 \text { S., R. } 11 \mathrm{E} . \ldots \ldots \ldots \ldots \ldots . .\end{array}$ & 4.09 & 38.06 & 52.59 & 5.26 & .48 & 1.10 \\
\hline 6 & $\begin{array}{l}\text { Gilson prospect, Coal Creek Canyon, } \\
\text { sec. 3, T.13 S., R. } 11 \text { E.............. }\end{array}$ & 5.42 & 36.32 & 52.16 & 6.10 & .54 & 1.00 \\
\hline 7 & Western part of Castlegate mine...... & 4. 72 & 39.13 & 48.45 & 7.70 & .49 & 1.30 \\
\hline 8 & Eastern part of Castlegate mine..... & 6. 13 & 40.07 & 45.45 & 8.35 & .56 & 3.50 \\
\hline 9 & No. 1 mine, Winterquarters.......... & 8.10 & 40.21 & 45.91 & 5.78 & .86 & 3.90 \\
\hline 10 & Clear Creek mine, Clear Creek......... & 7.02 & 41.89 & 45.80 & 5.29 & .57 & 3.10 \\
\hline 11 & $\begin{array}{r}\text { Huntington Canyon, Bear Gulch } \\
\text { prospect, NE. } 1, \text { sec. } 11, \mathrm{~T} .14 \mathrm{~S} ., \mathrm{R} . \\
6 \mathrm{E} .\end{array}$ & 5.19 & 43.89 & 46.91 & 4.01 & .31 & 2.30 \\
\hline 12 & $\begin{array}{l}\text { Huntington Canyon, near center of } \\
\text { S. } \frac{1}{2} \text { sec. } 24, \text { T. } 16 \mathrm{~S} ., \mathrm{R} .7 \mathrm{E} \ldots \ldots \ldots \ldots\end{array}$ & 6.04 & 38.96 & 48.40 & 6.60 & .83 & 2,90 \\
\hline 13 & $\begin{array}{l}\text { Larsen B rothers' mine, sec. 2, T. } 15 \text { S., } \\
\quad \text { R. } 6 \text { E } \ldots \ldots \ldots\end{array}$ & 8.46 & 41.17 & 46.09 & 4.28 & .48 & 3.50 \\
\hline 14 & $\begin{array}{r}\text { Emery coal mine, } b \text { sec. } 2, \text { T. } 23 \mathrm{~S} ., \mathrm{R} . \\
6 \mathrm{E} . \ldots \ldots \ldots \ldots \ldots \ldots \ldots \ldots \ldots \ldots \ldots\end{array}$ & 5.11 & 36.71 & 50.42 & 7.76 & 2.06 & .80 \\
\hline
\end{tabular}

a These analyses were made by the ted States Geological Survey coal-testing plant at St. Louis. F. M. Stanton, analyst.

$b$ The Emery coal is in the sandstone of the Red Plateau, 1,500 feet or more stratigraphically below the Book Cliffs coals. 
DESCRIPTIONS OF THE COAL BEDS.

Horse Canyon.-A coal bed is exposed in sec. 4, T. 16 S., R. 14 E., near the base of tho coal-bearing series. The bed is 14 feet 11 inches thick and is being opened for development. The coal is clean and massive. The floor is a massive sandstone. The roof of sandstone and shale 4 feet thick is succeeded by 2 feet of coal. The same bed was reported to be of equal thickness at prospects in secs. 3 and 9 of the samé township.

Sunnyside coals.-Two coal beds are mined by the Utah Fuel Company at Sunnyside, near the mouth of Whitmore Canyon, in sec. 32 , T. 14 S., R. 14 E., and sec. 5, T. 15 S., R. $14 \mathrm{E}$. These coal beds are near the base of the coal-bearing series. The lower conl ranges from 5 feet 3 inches to 6 feet 5 inches in thickness, while the upper bed, 30 feet above, averages about 5 feet 10 inches. Between the two beds are 30 feet of shale, sandstone, and thin coal. The lower Sunnyside coal contains a few thin and locally bony lentils. Its luster is rather dull and it is classed by the miner as "dead" coal. The upper bed is clean and bright. It yields considerable gas on mining and is referred to as a "live" coal. Two mines are in operation here. Both beds are worked from No.. 1 mine, while No. 2 mine is confined to the lower. All of the coal is run to a single tipple and is crushed and the entire product coked, the larger part in the coking plant at Sunnyside, the remainder being taken to the ovens at Castlegate.

The composition of the upper coal (No. 2 of the table) is almost identical with the Horse Canyon coal (No. 1). The analysis of the crushed product from all the Sunnyside mines shows a slightly higher percentage of ash and lower proportions of volatile matter and fixed carbon. The ratios between the volatile matter and fixed carbon, however, as indicated in the two analyses, are essentially the same.

Bear Canyon.-A traverse of the Book Cliffs scarp across T. 14 S., R. 13 E., which has not been subdivided into sections, locates the coal prospects of Bear Canyon in the N. $\frac{1}{2}$ sec. 10. Two prospect pits have been dug in the east fork of the canyon, on the coal at the base of the series. The bed has been partially burned near the outcrop and only $4 \frac{1}{2}$ feet of coal is exposed in the excavation.

Rock Canyon.-A coal bed 5 feet 10 inches thick is exposed by prospect in the SE. $\frac{1}{4}$ NE. $\frac{1}{4}$ sec. 32 , T. 13 S., R. 13 E. This coal is near the same horizon as the Sunnyside coal, being probably below the lower bed at that place.

Pace Canyon.-Prospecting has been done in the NW. $\frac{1}{4}$ NW. $\frac{1}{4}$ sec. 30, T. 13 S., R. 13 E., where the coal has been burned near the surface. A tunnel has been driven 50 feet on the burned bed, reaching the edge of the fresh conl. Five feet of fresh coal is exposed in another prospect, where the upper part was concealed. These coals are in the lower part of the coal-bearing series.

Dugout Canyon.-The lowest coal bed in this series has been mined by tunnel in the SE. $\frac{1}{4}$ NW. 1 sec. 23 , T. 13 S., R. 12 E. The bed is 9 feet 6 inches thick and contains a thin bony seam 18 inches below the top. The coal is otherwise massive and clean. Analysis No. 4 above shows the coal to be the equal of any other that has been tested in the Book Clifls field. Its content of ash, including the bony parting, is the lowest. About 100 feet higher in the section is a second bed showing 5 feet of coal in a shallow prospect. The exposure is at the forks of the canyon, near the center of the NW. $\frac{1}{4}$ sec. 23. This coal is apparently of good grade, except a thin parting near the top. A third double bed containing 4 feet of coal occurs 200 feet above the first, in a shallow prospect in the north side of the canyon. The parting of shale is 2 feet. One bench of what appears to be the same coul is exposed in the SE. $\frac{1}{4}$ sec. 23 , also in the SW. $\frac{1}{4}$ SW. $\frac{1}{4}$ sec. 15 . The showing is 2 to $2 \frac{1}{2}$ feet thick.

Spring Canyon.-A bed of coal 5 feet 4 inches thick has been opened in the NE. $\frac{1}{4}$ NW. $\frac{1}{4}$ sec. 21 , T. 13 S., R. 12 E. There is a thin parting in the coal 4 inches below the top. Otherwise the coal is massive. This bed is in the lower part of the coal-bearing series and is believed to be 50 feet above the horizon of the lowest seam. 
Soldier Canyon.-Coal has been mined for local use and prospected in a number of places in the central part of the coal series, in: the NE. $\frac{1}{4}$ sec. 18, T. $13 \mathrm{~S}$., R. $12 \mathrm{E}$. The coal worked is 2 feet 7 inches thick. A lower coal is exposed in the base of the gulch tributary to Soldier Canyon in the NE. $\frac{1}{4}$ sec. 13, T. 13 S., R. 11 E. This natural exposure shows $4 \frac{1}{2}$ feet of coal, but both the upper and lower parts are concealed.

Coal Canyon.-Six beds of coal are exposed in Coal Canyon in the E. $\frac{1}{2} \cdot \mathrm{NW} \cdot \frac{1}{4}$ sec.. 10 , T. 13 S., R: 11 E. Four of these, aggregating 22 feet, are thick enough to work. Three occur in natural exposures and two have been mined. The coal in the lower mine is 8 feet 6 inches thick and its quality is indicated by analysis No. 5 of the table above. It occurs between massive beds of sandstone, each 40 to 45 feet thick. The coal in the other mine, 155 feet higher in the section, is 5 feet thick and its quality is shown by analysis No. 6 . There is an intermediate bed, 5 feet 4 inches thick, but it contains a thin parting of bony coal The lowest bed, 3 feet thick, is 200 feet below the lower mine.

Deadman Canyon.-A coal bed 6 feet 10 inches thick has been prospected in the SE. $\frac{1}{4}$ SW. sec. 7, T. 13 S., R.11 E. It is estimated to be the same as the lowest bed mined in Coal Canyon. $A^{\prime}$ parting of shale occurs 16 inches below the top. Otherwise the coal appears to be equal to the corresponding bed mined in Coal Canyon.

Cordingly Canyon.-A coal bed 4 feet 3 inches thick has been opened in the east fork of Cordingly Canyon, in the NW. $\frac{1}{4}$ sec. 14, T. 13 S., R. 10 E. The coal has a shale roof and a massive sandstone floor. It has a bright luster and is clean, but fractures easily, and a considerable quantity of slack is produced in mining. This coal is apparently at the base of the coal-bearing series. A coal bed 14 feet thick occurs 125 feet higher in the section, between a massive sandstone 60 feet thick below and another sandstone 6 to 8 feet thick above. A thin and variable parting of gnarly sandy shale occurs 4 feet below the top of the coal. The coal is massive and lustrous, but breaks readily into blocks in mining, in a similar manner to the lower bed. A short tunnel or drift has been run on this coal in the SE. 1 SW. $\frac{1}{4}$ sec. 11.

Ballinger mine.-The basal coal of the series is mined in the west fork of Cordingly Canyon, in the SE. $-\frac{1}{4}$ SW. $\frac{1}{4}$ sec. 10 , T. 13 S., R. 10 E. The coal is 20 feet thick, massive, and moderately hard. It mines for the most part in large irregular blocks. Sandstone occurs in contact both above and below. This coal is mined and transported by wagon for domestic use in the town of Price. Large rooms are excavated and wagons are driven into the face of the working to be loaded.

Wade prospects.-Three coal beds are exposed in the prospects of Wade and Lawley, in the SW. 1 NW. $\frac{1}{1}$ sec. 16, T. 13 S., R. 10 E. These coals oceur in the lower 160 feet of the coal-bearing series. The lowest eoal is the same as that in the Ballinger mine: It is 20 feet thick and massive. It rests directly on a solid sandstone and has a shaly sandstone roof. The second coal, 40 to 50 feet above, is similar in structure and appearance to the first. It is 8 feet 6 inches thick and lies in contact with the sandstone above and below. Of the third coal only the lower 15 feet are exposed. The excavation has not penetrated the weathered coal in the upper part, where the top of the bed is concealed. A thin shaly parting occurs $2 \frac{1}{2}$ feet above the base of this coal. The lower coal in this section is exposed in three openings in the west fork of Bull Canyon, near the south side of sec. 9 , T. 13 S.; R. $10 \mathrm{E}$.

Panther Canyon.-Two prospects have been driven on the coal at the base of the series in the NW. 1 NW. $\frac{1}{4}$ sec. 8 , T. 13 S.; R. 10 E. The coal has been burned near the surface in this vicinity and the shallow excavations revealed only a part of the coal.

Castlegate mine.-One of the coals near the base of the coal-bearing series is mined at Castlegate. The coal is worked in a series of slopes driven on the rise of the bed toward the south. At the entrance to the tenth rise in the northern part of the mined area the coal is a little more than 4 feet thick. At the face of the coal in the first rise in the southwestern part of the mine the thickness is 6 feet, while in the southeastern part it is 10 feet. At intermediate points it varies between these extremes. The coal is usually massive and clean. The floor is a solid sandstone and lies in low rolls or undulations, being so uneven 
that mining machines can not be successfully used. The roof is usually sandstone. Thin shales occur locally at the contact of the coal. The quality of the Castlegate coal is shown by analyses Nos. 7 and 8 of the table (p. 294). The mine has been driven through the ridge in places to a fringe of burned coal. The width of the burned aren varies and the high temperature of the rock in places where the boundary is approached indicates that spontaneous combustion of the coal probably has not entirely ceased.

Spring Canyon.-The lowest workable conl in the series is opened in two small mines in sec. 9 , T. 13 S., R. 9 E. The first, known locally as the Rhodes mine, is near the center of the section in the gulch leading into Spring Canyon. The coal is in three parts and the section is as follows:

Section at Rhodes mine.

1. Sandstone, partially exposed.

Ft. in.

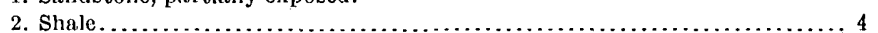

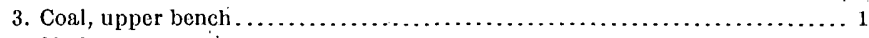

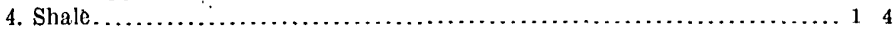

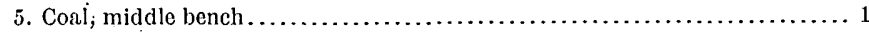

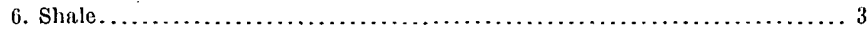

7. Basal bench of massive coal, underlain by solid white sandstone......... 5

The second exposure, in the NW. $\frac{1}{4}$, sec. 9, is known as the Pratt mine, and the seam worked at this place probably corresponds to the upper bench of the bed showing in the Rhodes mine, as indicated by the following section:

Section at Pratt mine.

1. Sandstone, partially exposed.

Ft. in.

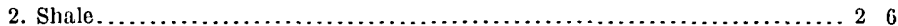

3. Massive coal.............................................. 5

4. Slope, talus covered, probably shale and lower coal of Rhodes mine....... 9

5. Massive white sandstone.

Pleasant Valley.-Several coal beds have been prospected in T. 12 S., R. 7 E., and some mining is being done for local consumption in secs. 30 and 31 . The mine in the NW: $\frac{1}{4}$ SE. $\frac{1}{4}$ sec. 30 shows a coal bed 5 feet 10 inches thick that is clear of shaly impurities and of fair quality. This coal is believed to be the same as the coal once mined in the NW. 1 sec. 31 , where a tunnel has been driven through the hill from the Winterquarters mine. On the north side of the canyon, in sec. 31 , a prospect shows 4 feet 9 inches of clean coal. A coal bed lower in the rocks and 6 to 7 feet thick is mined near the bottom of the canyon, east of the center of sec. 31. The coal from this mine is used for local consumption in the town of Scofield. A conl bed has been prospected very near the west side of the SW. $\frac{1}{4}$ sec. 11 , and both prospected and mined in the NW. $\frac{1}{4} \sec .13, \mathrm{~T}$. $12 \mathrm{~S}$., R. $7 \mathrm{E}$. At the first locality the coal is $3 \frac{1}{2}$ feet thick, while at the second $3 \frac{1}{2}$ to 4 feet of coal is exposed, the base being concealed. In each instance the coal rests on thick white sandstone. This coal is near the top of the coal-bearing series. A coal is mined for local use near the center of sec. 2, T. 12 S., R. 6 E. The bed is 4 feet thick, and the coal seems to be of good quality. It is apparently stratigraphically above the formation recognized as coal bearing in the Book Cliffs field. Prospectors who have worked at Winterquarters and Clear Creek are of the opinion that extensive north-south faults occur on the west side of Pleasant Valley, and that these faults explain the occurrence of coal in the high country in that vicinity. The smooth surface of the country makes it exceedingly difficult to demonstrate the existence of such faults, and without the evidence of definite stratigraphic correlation it can not be asserted. that these high coals are to be classed with those occurring near the base of the valley at Scofield, Winterquarters, and Clear Creek.

Scofield.-Mines once operated by the Union Pacific Railroad Company are located onehalf mile southeast of Scofield. It is reported on reputable authority that the coal is 25 to 30 feet thick. Only the middle portion of the bed was worked, it is explained, becaúse the coal formed a better roof than the overlying shales. A cave-in has occurred toward the 
south end of the coal workings, exposing about 30 feet of strata above the coal in the mine, including three beds of coal. The lowest of these beds is 14 inches thick, the middle 5 feet ' 3 inches, and the uppermost 9 feet. The coal of the two thicker beds appears to be of fair quality.

Winterquarters mines.-Coal is being mined on a large scale in the south side of the canyon at Winterquarters, which is located in the E. $\frac{1}{2}$ sec. 1 , T. 13 S., R. 6 E., and the W. $\frac{1}{2}$ sec. 6 , T. 13 S., R. 7 E. The coal in mine No. 1 now in operation varies in thickness from 9 feet at the entrance, near the center of the east side of sec. 1, T. 13 S., R. 6 E., to 16 feet at the face of the coal in the southeastern part of the working, near the center of sec. 7, T. $13 \mathrm{~S}$., R. 7 E. The coal is massive and generally clear of shaly impurities. Analysis No. 9 (see table above, p. 294), made from samples selected at the face of the working in the southeastern part of the mine is almost identical with that of the Castlegate coal. The same bed has been worked quite extensively from openings in the north side of the canyon at Winterquarters; also in the south side east of the town and near the center of the W. $\frac{1}{2}$ sec. $6, T$. 13 S., R. 7 E.

Two distinct. east-west faults were encountered in mine No. 1. Along the one on the north the downthrow is 40 feet on the south and along the other the downthrow is 90 feet on the north. The result is an east-west dropped block a few hundred feet in width. The coal rises toward the south at an angle of about $3^{\circ}$ and the downthrown block is overcome in mining by increase in the grade of the slope.

The coal and associated strata in mine No. 1 and in the mine opposite on the north side of the canyon are cut by a number of dikes of basic igneous rocks bearing east and west. The dike in the south mine, nearly 150 feet from the entrance, is approximately vertical, 5 feet in width at the floor and 1 foot at the roof. It swells to a width of 10 feet in the coal bed, which is here 9 feet thick and has metamorphosed the coal, producing a coke-like substance to a distance of 2 to 3 feet on each side. The dike in the northern mine occurs about 300 feet from the mouth of the slope. It is approximately 10 feet thick, and has coked the coal in a similar manner as in mine No. 1. Thin dikes of igneous rock 1 foot and less in thickness are reported by Superintendent Thomas J. Parmley to occur at other places in these mines. Such thin dikes, it is stated, do not metamorphose the coal appreciably.

Crandall Canyon.-A coal bed is mined for local consumption in the SE. 1 SW. $\frac{1}{4}$ sec. 13 , T. 13 S., R. 6 E., near the head of Crandall Canyon. This canyon leads into Pleasant Valley midway between Scofield and Clear Creek. The coal is approximately 12 feet thick and is massive and clean. It is mined on the rise toward the south.

Clear Creek mine.-This mine is in the town of Clear Creek, near the head of Pleasant Valley. The Clear Creek coal varies in thickness in a north-south direction through the mine working, a length of nearly 7,000 feet. In the southern part the coal is massive and is 13 feet 5 inches thick. No shaly or other impurities were noted. Near the center of the workings a thin shale parting enters the coal. Toward the north and within a distance of 2,000 feet the shale swells to a thickness of 16 feet, dividing the coal into two benches. In the northern part of the mine, where the shaly parting is thick, only the upper bench, 4 to 6 feet thick, is worked.

Several small north-south faults occur near the outcrop, displacing the coal vertically from 5 to 40 feet. Nearly 2,200 feet east of the entrance to the mine a large fault occurs, bearing a few degrees east of north, by which the coal is displaced out of sight. The amount of throw was not determined.

Coal was being prospected in rocks apparently above the coal-bearing series hitherto recognized in the SW. $\frac{1}{4}$ sec. 31 , T. 13 S., R. 7 E., near the head of the gulch bearing west from Clear Creek. The coal bed is about 10 feet thick, and it is regarded by the prospectors as being the same as one of the workable beds found in Pleașant Valley, 1,000 to 1,100 feet lower in the section. The rocks in this region, as elsewhere in the Book Cliffs field, are almost horizontal, and the coal in Huntington Canyon 2 miles southwest of the prospect is near the same stratigraphic position and about the same elevation above sea level as the Clear Creek coal. If the position of the coal near the head of the gulch west of Clear Creek is explained by faulting, as 
claimed by prospectors, two faults instead of one are required, and it will be necessary to show that a part of the high country between Huntington Canyon and Pleasant Valley is fauited upward a thousand feet or more. Certain thick and distinct sandstone beds; always associated with the lower conls, were not noted in the vicinity of the prospects west of Clear Creek. Rock exposures are less frequent, however, toward the mountain tops than in the lower parts of the canyons.

Miller Canyon.-Two coal beds have been exposed by prospect near the center of the N. $\frac{1}{2}$. sec. 32 , T. 15 S., R. 8 E. The lower bed, 10 feet thick, is apparently 25 feet above the horizon of the lowest coal in the Book Cliffs section. The second bed is 4 feet thick and is separated from the first by 5 to 6 feet of shale. The upper coal is overlain by massive sandstone. Near the center of the west side of sec. 20 several beds of coal occur near the base of the coal-bearing rocks in natural exposures. Some of these give evidence of workable thickness, though the coal is disintegrated at the surface.

Cedar Canyon.-The basal coal in the Book Cliffs section has been worked occasionally for a number of years in the north side of Cedar Canyon, in, the SW. $\frac{1}{4}$ sec. 9, T. 16 S., R. 8 E. The coal is 20 feet thick and is separated locally into three benches by variable thin bony and shaly partings. The lower bench, 11 feet thick, is massive and clean. The middle bench is 5 feet thick and the upper bench 4 feet. The coal lies on massive sandstone and is succeeded by beds of thin and shaly sandstone. A tunnel 300 to 400 feet long has been driven toward the north on the lower coal, a short distance west of the present working, in the SE. $\frac{1}{1} \mathrm{sec} .8$. The coal in this mine varies in thickness from 16 to 20 feet, and it is reported by one of the operators that no shaly partings were found. The operations in Cedar Creek are conducted by Messrs. Howard \& Sons, of Huntington, and they are known as the Howard mine. A coal bed is partially exposed in the north side of the canyon 400 feet stratigraphically above the Howard mine. Several feet of disintegrated coal are shown, but the full thickness of the bed was not determined.

Huntington Canyon.-Systematic prospecting has been done in Huntington Canyon through Tps. 16 and 17 S., R. 7 E. The prospectors confined their attention to the coals in the lower part of the coal-bearing section, and it is reported by the State coal-mine inspector that more than 1,000 openings have been made on these beds.

Twelve or more prospects have been made exposing workable coal beds in Bear Gulch, in secs. 24 and 25 , T. 16 S., R. 7 E. Two of the lower coals are exposed on the west side of the gulch, in the northwest corner of sec. 25. The section of coals and associated rocks is as follows:

Section in Bear Gulch, NW. $\frac{1}{4}$ sec. 25, T. 16 S., R. 7 E.

1. Heavy sandstone. Feet.

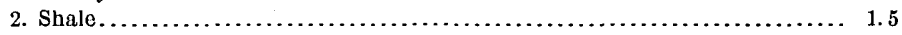

3. Massive coal................................................ 10

4. Shale and sandstone, alternating beds; the sandstone at the top makes the floor of the upper conl. .......................................... 40

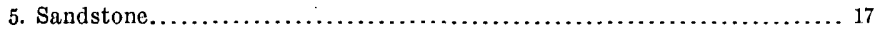

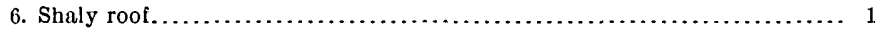

7. Massive coal................................................ 12

8. Massive sandstone; base of lower coal.

Five other beds of workable coals, aggregating a thickness of 48 feet, are reported independently by two reputable prospectors to have been opened at several places in 300 feet of strata on the east side of the gulch, in the $\mathrm{S}$. 3 sec. 24. Several prospects have been made on some of these coals also in the west half of the same section.

A massive coal bed, 13 feet 4 inches thick, situated near the base of the coal-bearing section, is mined for local use in Deer Gulch, in the NW. $\frac{1}{4}$ sec. 11, T. 17 S., R. 7 E. A coal bed 3 feet thick has been prospected on the west side of the gulch, near the middle of the east side of sec. 10. This coal is about 175 feet above the coal in the mine.

A coal bed partially burned, exposed in Meeting House Gulch, in the NE. $\frac{1}{4}$ SE. $\frac{1}{1}$ sec. 34 , T. 16 S., R. 7 E., shows 3 feet of coal. Two beds of coal are opened in three prospects near 
together in Ridley GuIch, near the northeast corner of sec. 28. The lower of these two beds, 12 feet thick, is at the base of the coal-bearing series and rests on massive sandstone. The other bed, partially burned, occurs 25 feet higher in the section. Five feet of coal are exposed. A number of other prospects have been made on coal farther up the gulch in the same section.

A coal bed 9 feet thick, at the base of the coal-bearing series, has been prospected at the mouth of Trail Gulch, near the center of the NE. 1 sec. 22 , T. 16 S., R. 7 E. It rests on massive white sandstone and is overlain by 4 feet of blue shale. On the east side of the gulch, near the southeast corner of sec. 15, a coal bed 5 to 6 feet thick is exposed. Farther up the gulch, near the west side of sec. 14, two prospects are reported as showing 8 feet of coal. Coals in the lower part of the series have been prospected in many other localities in Huntington Canyon, notably in Mill, Crandall, and Tie gulches, in secs. 21, 16, 5, and 3, T. 16 S., R. 7 E.

Connellville mine.-Coal has been mined at various times for a number of years in Huntington Canyon, in sec. 11, T. 14 S., R. 6 E. The early settlement here was named Connellville. At the present time all habitations are removed except a few for temporary occupation of miners. The coal is mined and hauled to Fairview for domestic consumption. In the only mine now operated the coal is 9 to 11 feet thick. The same bed has been worked at a number of places near the mine and the coal was once coked in a few ovens, now fallen into decay. Several prospects have been made in the vicinity near the base of the series, but they were not open for inspection.

Larsen mine.-A coal bed 8 feet thick is located in the SE. $\frac{1}{4}$ SW. $\frac{1}{4}$ sec. 2, T. 15 S., R. $6 \mathrm{E}$., near the head of the west fork of Huntington Canyon. It is owned and mined at the present time by Messrs. P. A. and L. Larsen to supply domestic fuel for the town of Mount Pleasant. The quality of the coal, as shown by analysis No. 13 (see table, p. 294), is essentially the same as the coals tested from other parts of the Book Cliffs field. The coal occurs between beds of massive sandstone about 350 feet above the base of the coal-bearing series. A bed of coal 3 feet thick is reported by Larsen Brothers to occur about $130^{\circ}$ feet below the mine.

Otterson mine.-A coal bed at the base of the series, located very near the south side of the NE. $\frac{1}{4}$ sec. 26 , T. 17 S., R. 7 E., is mined occasionally for domestic consumption at Castledale. The workable part of the bed is 11 feet 10 inches thick, but is divided by a thin parting of shale. The coal seems to be of the average grade of coals in the Book Cliffs field.

Section of coal and associated rocks at Otterson mine.

1. Coal crop, weathered.

Ft. in.

2. Massive sandstone.

3. Thin coal seam.

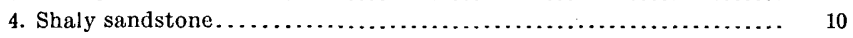

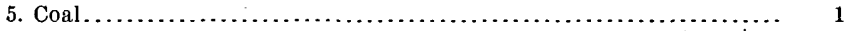

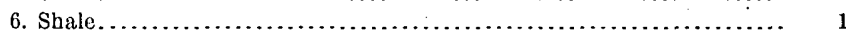

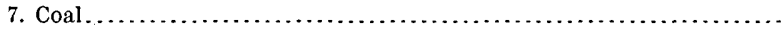

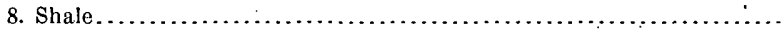

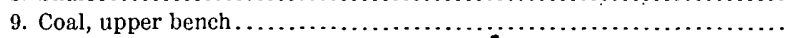

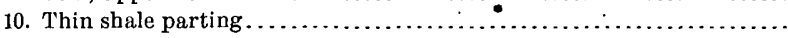

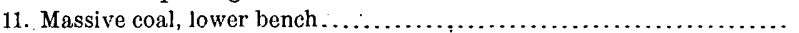

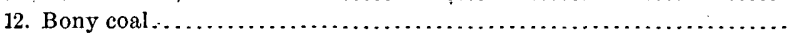

13. Sandstone............................................... 3

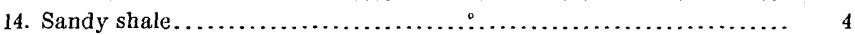

15. Massive sandstone......................................... $60-80$

Reed mine.-A coal bed near the same stratigraphic position as that worked at the Otterson mine has been opened for local use near the center of the south side of sec. 22 , T. $17 \mathrm{~S}$, R. $7 \mathrm{E}$. The coal is 7 feet 6 inches thick and rests on massive white sandstone. The roof of the coal is a thin bony shale that is overlain by 60 to 80 feet of sandstone. Both the Reed and Otterson mines occur in the cliffs near the heads of gulches leading toward the south, and are approached by steep graded wagon roads. 
Johnson mine, Cottonwood Canyon.-The Johnson mine is driven on a bed of coal 7 feet 10 inches thick, situated on the west side of Cottonwood Canyon, in the SW. $\frac{1}{1}$ NE. $\frac{1}{1} \mathrm{sec}$. 25 , T. 17 S., R. 6 E. The floor of the coal is a massive white sandstone. Shaly sandstone 3 feet thick forms the roof. A coal bed 5 feet thick is reported by Mr. Johnson, the operator of the mine, to occur above the shaly sandstone; also 50 feet higher in the section a bed 3 feet thick is said to have been found. A bed of shale and bony coal occurs 50 to 60 feet below that of the Johnson mine, but it has been proved to be of no value.

Ferron Canyon.-A coal bed 8 feet thick is reported by reputable authorities to occur in Ferron Canyon west of the faulted area in T. 19 S., R. 6 E. This township has not been divided into sections. A traverse up the canyon to the vicinity of the prospect locates it near where the southeast corner of sec. 19 will be placed.

Quitchupah Canyon.-The outcrops of coal-bearing strata in Quitchupah Canyon extend westward into the unsurveyed part of the Wasatch Plateau. A coal bed reported to be 6 to 10 feet thick has been prospected near the base of the coal-bearing rocks in the NE. $\frac{1}{4}$ sec. 17, T. 22 S., R. 5 E. Another prospect exposing 16 feet of coal is said to have been made in the canyon near the eastern and unsurveyed part of T. 22 S., R. 4 E. Time did not permit an investigation of these prospects.

Ivie Creek Canyon.-Ivie Creek Canyon is s.tuated near the south end of the Book Cliffs field. Coal beds near the base of the series have been prospected on Clear and Red creeks, which flow northward from Mount Hilgard into Ivie Creek; also on Ivie Creek near the mouth of Red Creek. In no instance was the whole thickness of the coal exposed. A prospect on Clear Creek; near the center of the north side of sec. 10, T. 24 S., R. 4 E., showed 6 feet of weathered coal without exposing the base of the bed. A coal prospect on Red Creek, near the north side of the NW. $\frac{1}{4}$ sec. 3, T. 24 S., R. 4 E., appears to be on the same bed as that opened on Clear Creek. Three feet of the upper part of the bed are exposed in the Red Creek prospect. Two coal beds have been opened in shallow prospects on the north side of Ivie Creek, in the SW. $\frac{1}{4}$ sec. 34, T. 23 S., R. 4 E. The beds are decomposed and it is believed the exposures do not represent the true thickness of the coal. The upper exposure shows 2 feet, while the lower is 4 to 5 feet thick. The intervening strata consist of 18 feet of shale.

Emery coals.-These beds occur in association with the sandstone that lies stratigraphically below the shale of Castle Valley. They are exposed in the breaks and bluffs of Muddy Creek 4 to 6 miles southeast of Emery. The beds are referred to as the Emery couls since they are ut:lized to supply Emery with domestic fuel and the town owns the land in which the most valuable mine is situated. A section of the strata including the coals is given above (p. 294), in the discussion of the sandstones of the Red Plateau. Two coal beds of workable thickness were noted. The lower coal is variable both in thickness and in respect to its included strata of bone and shale. A tunnel has been made on the lower bed near the center of sec. 26 , T. 22 S., R. 6 E. The coal occurs in two partings separated by 14 inches of shale. The lower workable bench consists of 6 feet of bony coal. The upper layer is 14 inches thick. Across the gulch in which the mine occurs the coal seems to thin out within a distance of one-fourth mile. A coal bed near the same position in the strata crops out in the cliff's on the west side of Muddy Creek Canyon, in the NE. $\frac{1}{4}$ sec. 35, T. 22 S., R. $6 \mathrm{E}$. The coal is in three benches and is similar in quality to that at the mine. The lower and middle benches are each 2 feet thick, while the upper is 1 foot 9 inches. They are separated by bands of bony shale 4 to 6 inches thick.

Emery mine.-An upper coal bed occurs 125 to 150 feet higher in the section and within 50 feet of the top of the sandstone series below the shale of Castle Valley. This coal is in a single massive bed 5 feet thick. It is incased in shale and adheres to the roof and floor so strongly that it is separated with difficulty in mining. The coal contains no shaly or bony partings and compares favorably in composition with coals of the Book Cliffs series, as shown by its analys.s (see table, p. 294). The mine is situated in the NE. $\frac{1}{4} \mathrm{SW}$. $\frac{1}{4}$ sec. 2, T. 23 S., R. 6 E., on the highland west of Muddy Creek Canyon. A drift has been driven 50 feet on the coal and two rooms have been turned.

Bull. 285-06-20 


\section{CONCLUSION.}

With the possible exception of one or two coal beds occurring in the high land west of Pleasant Valley all the coals of value known at the present time in the Book Cliffs field are found in the lower part of the coal-bearing strata and near the base of the Laramie formation. At no locality investigated was it found that the entire coal-bearing section had been thoroughly prospected. The beds in the lower part of the series are the more conveniently situated for exploitation and were found usually of ample thickness for profitable working: For these reasons the attention of the prospector and miner has been devoted to them. At every locality investigated for more than 100 miles in the Book Cliffs field coals ranging from 3 to 20 feet in thickness were found where the lower part of the section of the coal-bearing series had been carefully prospected.

The coals in the different parts of the field are remarkably uniform in their physical characteristics. 'They are black, moderately hard, and usually massive. Occasional shale partings occurin the bed, but one or the other, and sometimes both, benches are sufficiently thick to be profitably mined.

The composition of the coals in various parts of the field and in several beds varies but little; in so far as proximate chemical analyses show. The fuel ratios in the 14 samples analyzed range between the extremes of 1.06 and 1.46. The content of sulphur is remarkably low and uniform. The coking property of the coals has been tested in but few localities; and of these only the coals mined at Sunnyside are known to be coked. 


\section{MINERAL RESOURCES OF THE BIGHORN MOUNTAIN REGION.}

By N. H. DARToN.

\section{GENERAL STATEMENT.}

Although in the Bighorn uplift there is an extensive area of the old crystalline rocks, they appear to give but little promise of yielding valuable mineral deposits. Much of the area has been prospected, but only a few claims have been worked to any notable extent, and as yet they have not paid expenses. Gold and copper have been found in small amounts and it is claimed, perhaps erroneously, that platinum was detected. The Red Beds surroundng the uplift contain large deposits of gypsum. Beds of bentonite and nodules of phosphate of lime occur in the Benton shales and inexhaust.ble supplies of limestone and building stones are obtainable from the mountains. Extensive beds of lignite coal underlie portions of the adjacent plains on both sides of the mountains, and these are mined profitably. Clays for brick making and other uses are available at many localities, but are in limited demand. $a$

\section{COAL.}

The "Laramie" formation is extensively developed in the wide synclinal basins on both sides of the Bighorn Mountains, and, as in most other regions, this formation contains large deposits of lignite. In portions of the area these deposits are thick and to some extent utilized commercially. The formation is several thousand feet thick, and on the eastern side of the mountains compr.ses three members, of which the upper one may be, in part at least, younger than Laramie in age. The basal member, the Piney formation, consists of 2,000 feet of sandstone and carbonaceous shale lying on the Parkman sandstone, which carries marine fossils and is supposed to represent the Fox Hills, for it overlies typical Pierre shale. The medial member is a thick mass of conglomerate of considerable extent, which contains materials from the mountains to the west. It has been designated the Kingsbury conglomerate. The coal measures occur next above and have a thickness of 4,000 feet or more. They have been designated the De Smet formation. In places, especially in the upper measures, the coals and coaly shales are widely burned and the result:ng clinker, or clay baked and reddened by the heat, is a conspicuous and characteristic feature in the outcrop region. At some localities the coal is still burning. On the east side of the Bighorn Mountains the principal mines are near Sheridan and Buffalo, but the lignite could be worked at many other localities. The largest mines are at and near Dietz, on Big Goose Creek, 7 miles below Sheridan. The succession at this place is as follows:

Section at Dietz coal mine near Sheridan, Wyo.

Feet.

Rusty slabby sandstone.......................................... 2

Light-gray soft sandstone.......................................... 18

Dark coaly shale with fragmentary leaf impressions................. 2

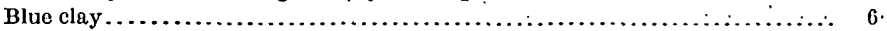

a A detailed description of the Geology of the Bighorn Mountains, by N. H. Darton, is now in press as Professional Paper No. 51, U. S. Geol. Survey. 


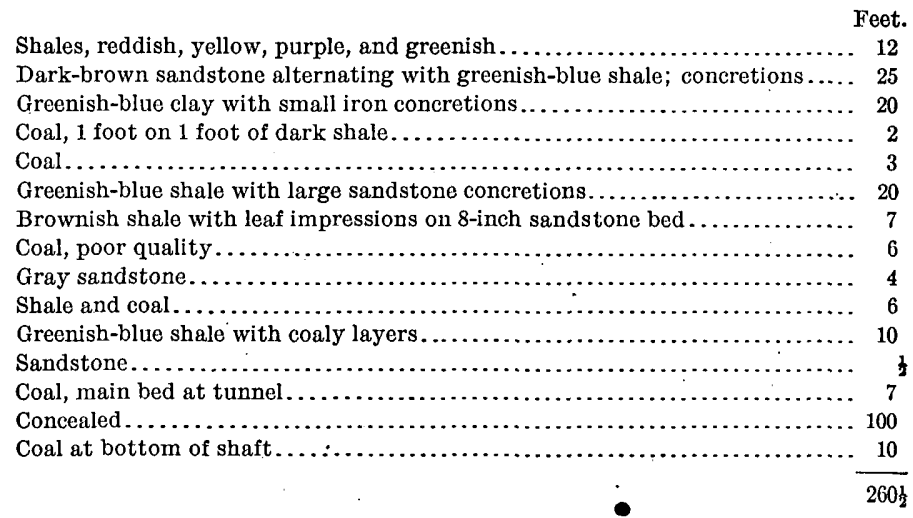

The 7 -foot bed of coal has been extensively mined. The overlying layer of hard sandstone thins out about half a mile back in the mines and the two coal beds unite. The coal is of good quality for lignite, but slacks easily on exposure to the air. It is used on one section of the Burlington Railroad, about thirty locomotives having been specially modified for burning it. Besides supplying the railroad, the coal is shipped to local dealers in both the East and the West, especially at points in eastern Wyoming and Montana. It supplies some coal to the city of Sheridan, but the greater part of the coal used by the citizens of that place is furnished by other mines along Big Goose and Beaver creeks.

The Dietz tunnel has been worked back into the hills about $1 \frac{1}{2}$ miles. It rises with a slight incline for a short distance and then runs nearly on a level only a few feet below the surface of the ground. There are several side entries to the main tunnel which lead into rooms. The mine is kept well timbered, and as fast as the rooms are worked out the timbers are removed and the walls allowed to cave in. In 1902 a shaft was sunk 150 feet deep about half a mile northeast of the old tunnel. In this shaft the 7-foot seam mined in the old tunnel was penetrated at a depth of 40 feet, and a second bed 10 feet thick at a depth of 140 feet. This lower bed contains a coal thatis harder a d, as regarded by the miners, of better quality than that found in the old tunnel. It does not air slack easily and, according to tests made, is a good quality of steam coal. From the bottom of this shaft a main entry 10 feet deep runs over a quarter of a mile in a northeasterly direction, with side entries in process of construction. This shaft is equipped with a modern derrick, new engines for hoisting, and an elevator for loading coal on the railroad cars. The output of the Dietz Company is said to be 50 cars a day during the busy season, and the coal sells at the rate of $\$ 2$ a ton.

On Owl Creek and the divide to the north the coal measures contain a coal deposit 18 feet thick, which is extensively mined. The coal outcrops across the divide toward Soldiers Creek, but appears to thin out rapidly in that direction, being only 6 feet thick in an abandoned mine on the north slope. To the south the coal outcrop encircles the hill lying between the mouths of Owl and Big Goose creeks, and is opened extensively at the Big Goose coal mine, on the east side of the hill. The bed here is 14 feet thick; but at Nelson Brothers' mine, $2 \frac{1}{2}$ miles farther southeast, on the east side of Beaver Valley, it thickens to 21 feet of pure coal. The strike of the beds is northwest and southeast in this region and the dip about $4^{\circ}$. The coal thins in every direction from the Nelson mine. The overlying beds exposed at intervals down Goose Creek are soft sandstones and shales with coaly layers.

The coal mines on Owl Creek, 2 miles northeast of Beckton, are owned and operated by Mr. R. S. Addleman. They were opened in 1897. The main tunnel is 800 feet long and runs from northeast to southwest, or nearly at right angles to the dip, which is about $4^{\circ} \mathrm{NE}$. In 1902 there were 12 rooms 200 feet long, 18 feet wide, and 7 feet high. The coal deposit is 18 feet thick in its thickest portion, and 12 feet of this is good coal, but only 7 feet near 
the middle of the bed is worked. The top 3 feet is a mixture of coal and shale. The production is about 4,000 tons a year, which sells at $\$ 1$ a ton at the mine. Half a mile east, in Big Goose Creek Valley, the same bed is opened at the Big Goose coal mine by Mr. H. Timm. Mining was begun in 1890, and in 1902 the main tunnel was 600 feet long, with two side entries 240 feet long, and had six rooms. The mine is operated only part of the year and has an output of 5 tons a day, valued at $\$ 1$ a ton at the mine. It is used mainly in Sheridan and is entirely satisfactory for domestic use. Two and $a$ half miles southeast, on the east side of Beaver Creek Valley, 2 miles above its mouth, is Nelson Brothers' coal mine, which has been in operation since 1899. The bed is the same one as in the other mines, but it is 21 feet thick without a parting. The owners are working only 9 feet at the bottom of the bed. There is a main entry 350 feet long, with numerous rooms 18 feet wide and 9 feet high. The mine is well timbered and has a tramway in the main entry. Eight men are employed in winter and two in summer. The average output is 15 tons a day in winter, which sells at $\$ 1.25$ a ton at the mine.

At a coal prospect 3 miles northeast of Wolf post-office there is a layer of coal 1 foot thick. It is overlain by dark-reddish shales containing plant remains and lies on blue clay.

At one time coal was worked on North Dry Creek 2 miles south of Tongue River, but as the opening has caved in the beds could not be measured. In the bed of the creek near by 4 feet of coal are exposed, overlain by dark-brown leaf-bearing shales. The bottom of the coal bed is below the creek and the thickness could not be ascertained. Apparently it is the bed which was worked in the mine. The coal is of a good quality and easily mined.

Three miles east of Ranchester a draw on the south side of Tongue River exposes the following beds, having a very low dip:

Section 3. miles east of Ranchester, Wyo.

Feet.

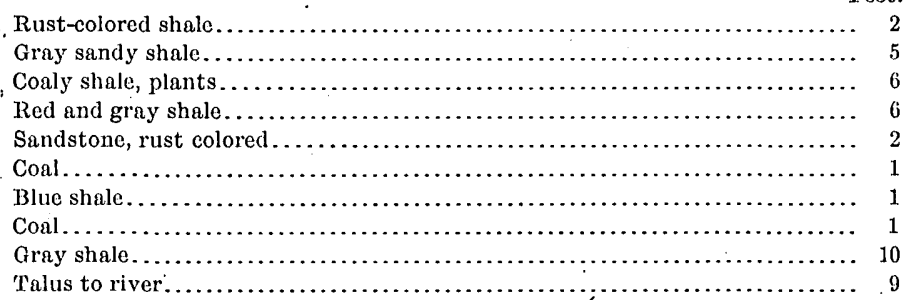

These beds appear again north of the river, along the divide between Sixmile and Early creeks. On the summit of this ridge several thin layers of coal are exposed, varying from 1 inch to 4 inches thick, separated by 20 to 25 feet of bluish-green clay with ironstone concretions. On the north side of Early Creek, 3 miles northeast of Ranchester, the next higher beds are exposed, as follows:

Section 3 miles northeast of Ranchester, Wyo.

Feet.

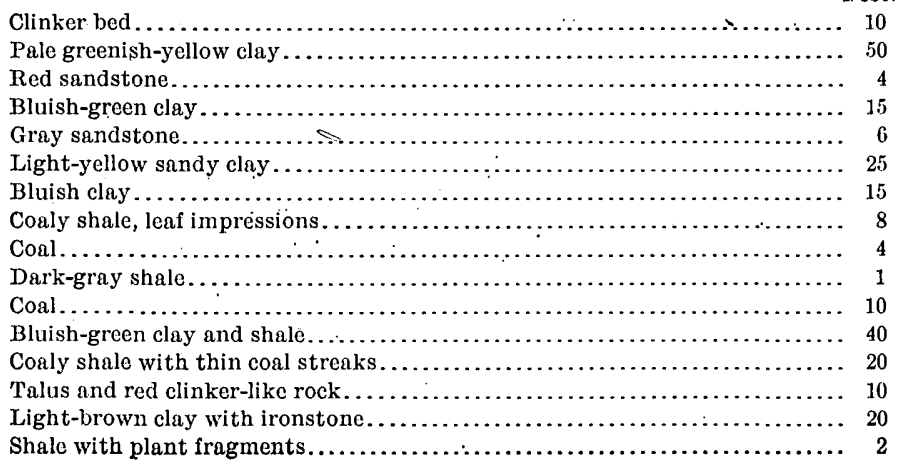




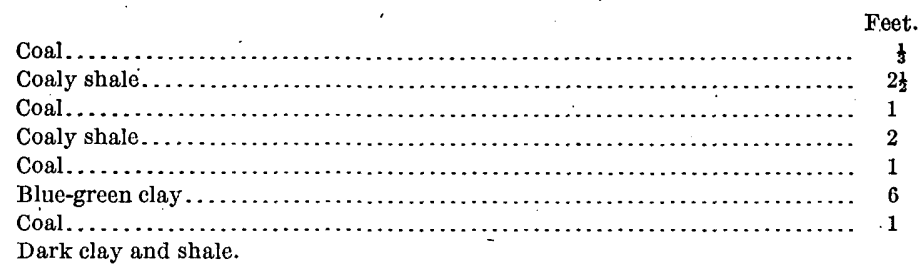

The upper beds of this section cross Tongue River just east of the mouth of Early Creek, where the coal is mined in small amount. The thickness of the bed varies from 5 to $6 \frac{1}{2}$ feet. This coal is also mined to some extent for local use on the ridge to the northwest.

In the Clear Creek region the lignite-bearing beds of the De Smet formation succeed the Kingsbury conglomerate near Buffalo and extend eastward with a width of about 18 miles on Clear Creek. The dips are to the northeast at angles of from $10^{\circ}$ to $20^{\circ}$ a short distance west of Buffalo, but the amount decreases rapidly to the east. The beds comprise 5,000 feet or more of alternating shales and sandstones, the former mostly carbonaceous and the latter soft and massive. The stratigraphy is variable, and no regular succession of beds could be established. The coal occurs in local beds at various horizons, and, although most of the deposits appear to be of limited extent, a large amount of coal is available. There are four principal horizons lying near together a few hundred feet above the base of the formation. In the region northeast and east of Buffalo part of the coal has burned out near the the surface and the heat has baked the adjoining shales into red clinkers over wide areas. At some localities the coal is still burning, notably at an abandoned coal mine near the southeast corner of Lake De Smet.

The lowest member of the coal measures is a series of sandstones lying on the Kingsbury conglomerate and merging upward into coaly shale which extends north and south in the region north and west of Buffalo. On the east side of Rock Creek, in the northeast corner of T. 51, R. 83, it is 6 feet thick and contains three or four streaks of coal of poor quality. The principal coal deposits of the Buffalo region occur considerably higher in the formation, and one series outcrops along a zone extending from the southeast corner of Lake De Smet to the mouth of Rock Creek and thence east of Buffalo. Near Lake De Smet the old mines have caved in, but they appear to have worked about 4 or 5 feet of coal. It is overlain by a bed of clinkers. Near the mouth of Rock Creek, at the Bodan coal mine, a tunnel has been run in on a 12 -foot coal bed of good quality, which is worked to a moderate extent every winter. The section at this place is as follows:

$$
\text { Section at Bodan coal mine, near Buffalo, Wyo. }
$$

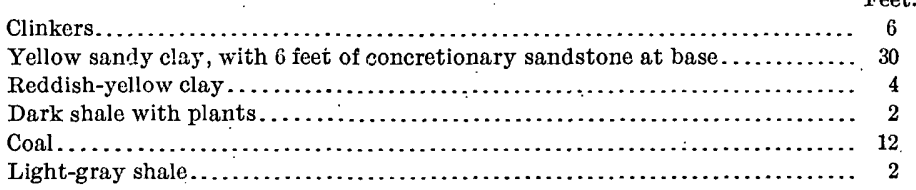

The coal appears to be in a lens-shaped deposit and thins considerably to the north and south. A short distance north an 8-inch coal bed is seen underlying the clinker bed. A mile east of the Bodan mine and at a somewhat higher horizon is the old Foot mine, in which an 8 -foot bed has been worked. It is overlain by 20 feet of light, sandy clay, 20 feet of dark shale with thin coaly streaks, and 15 feet of yellow sandy clay. This coal deposit is on fire and has been burning for several years. The following section at Monkers \& Mather's mine, a mile east of Buffalo, shows the principal succession in that region. The lower 7-foot bed is probably the lowest bed of importance in the formation. The upper 7 -foot bed is the one that reaches the surface near the mouth of Rock Creek, where, as above stated, it has been mined at several places. The next bed lies some distance above and is worked at the Mitchell mine, $2 \frac{1}{2}$ miles east of Buffalo, a short distance below the lower clinker bed. It is 6 to 8 feet thick. 
Section at Monkers \& Mather's coal mine east of Buffalo, Wyo.

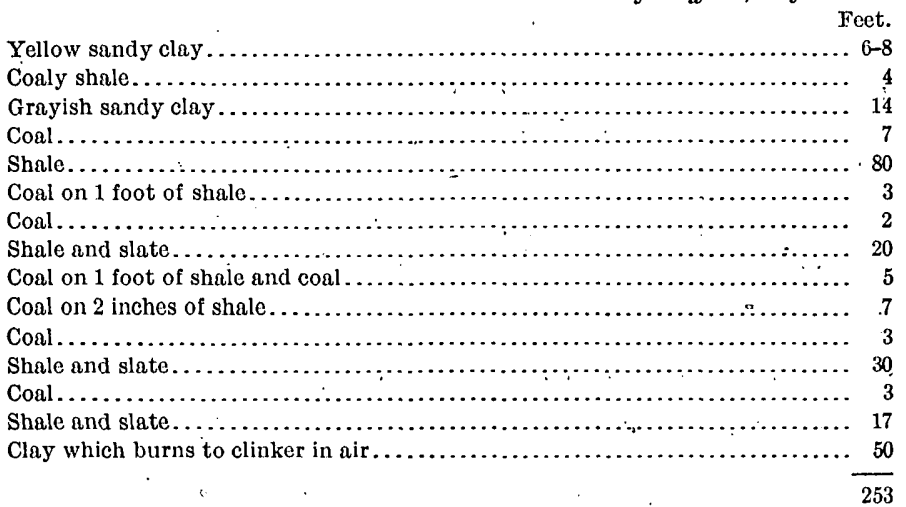

In the vicinity of Buffalo the lignites are mined extensively for local use. There are four principal beds which outcrop in a zone of moderate width, passing north and south a short. distance east of Buffalo. The beds generally vary from 5 to 12 feet in thickness and lie in a series about 200 feet thick, which dips very gently to the northeast. The principal mines are within 3 miles of Buffalo and lie to the east and north. Monkers \& Mather's mine, the section of which is given above, is about 1 mile east of the town and is the principal producer. Its annual output averages about 2,000 tons, and the selling price is about $\$ 1.50$ a ton at the mine. The workings are underground.

The highest coals in the Clear Creek region are found in isolated areas in the buttes and plateaus of the clinker region 10 miles northeast of Buffalo. The beds apparently are remnants of deposits which are burned out elsewhere. They are included in strata free from clinker and in part capped by gray sandstone and clay, which overlies the upper clinker bed in some other places in the region. A number of such occurrences were observed in and adjoining the northwest corner of T. 51, R. 80.

In their southern extension toward Crazywoman Creek the De Smet coal measures contain coal, but no large deposits appear. There is a uniform succession of sandstones and shales, with coaly layers at intervals. The stratigraphy. is less marked than in the region to the north, and the only noticeable feature is the occurrence of clinker for a short distance in two lines of small buttes south and southwest of Long's ranch. Coal 6 feet thick is mined 2 miles southwest of Long's ranch, but it is not of very good quality. Toward Powder River thicker beds appear, and in the region about the head of the Belle Fourche there are extensive and thick beds, which extend southward to North Platte River to the mines at Glen Rock.

\section{GOLD.}

At intervals during the past decade attempts have been made to develop gold mines in the vicinity of Bald Mountain, but the results have not been encouraging. The basa gravels of the Deadwood formation, especially where mixed with disintegrated portions of the underlying granite, contain fine-grained free gold, but the values are low and the distribution irregular. The highest assays reported are $\$ 2$ a.ton, but the amount is usually so - much less that the workings have not been profitable. At a point about 2 miles west of the abandoned Bald Mountain cabins a mill with jig machine was in operation in 1903, working the disintegrated sandstone and granite at the base of the Deadwood formation, but it is stated that only small portions of the material yielded paying results. Some of the small intrusive dikes or chimneys about Fortunatus Mill are reported to contain some gold, but the value is low and the extent of mineralization small.

Another locality at which the basal sandstone of the Deadwood formation has been found to contain gold is at the head of Kelly Creek, southwest of Buffalo. At this place a 3-stamp 
mill was built several years ago, which obtained a small product, but apparently without sufficient profit to give encouragement to continued operations.

The granite area of the Bighorn uplift has been extensively prospected for metallic minerals, but the results appear to be not encouraging. Small amounts of free gold occur in quartz veins connected with the diabase dikes in the granite, but the values are low. There are several prospects on the headwaters of East Fork of Big Goose Creek. The work was begun in 1898 and, although the results have appeared promising, no ore has been produced. A 350-foot tunnel is projected at one of the mines. The rock is a dark-gray granite containing some pyrite and a trace of copper. Assays of gold showing $\$ 4$ a ton are reported. In one opening $\$ 12$ of gold and $\$ 7$ of silver a ton were found.

Considerable prospecting has been done in two large dikes southeast of Willitt Creek. The minerals are galena and pyrite, occurring in small streaks in quartz along diabase contacts. A few small prospects have been made in a quartz vein about a mile north of.Tongue River Cabin. A mine on the ridge southwest of the mouth of South Fork of Tongue River, belonging to the Nickel and Copper Refining Company, has been worked at intervals since 1896, but is now abandoned. There is a shaft 180 feet deep, with buildings and extensive machinery. The shaft is sunk along the contact of a large dike of peridotite and a quartz vein, but apparently very little mineral was found. It is stated that platinum was one of the principal objects of the enterprise. Extensive prospecting was done at intervals along the dike, which has a length of about 3 miles. Traces of gold are found in gravels and sands along some of the streams flowing out of the mountains, but they have not been sufficiently promising to lead to any placer mining.

Rich gold prospects have been found in the crystalline rock area in the center of the Bridger uplift, 7 miles southwest of Deranch. Very promising prospects of gold have been found recently. The metal appears to be free and is partly in quartz veins and partly in association with copper ores. The extent of the deposit has not been ascertained, but numerous claims have been located, and doubtless these will soon be thoroughly explored.

Very little prospecting has been done in the high ridges about Cloud Peak, and possibly some of the great dikes which traverse the granite in that region may carry minerals of value, such as gold or even platinum, and the rare earths, some of which now have considerable economic importance. The dike rocks contain magnetite and titanic iron, but they are intimately intermixed with the other constituents, and consequently are of no value Assays of ordinary rock from the two largest dikes showed no traces of valuable metals.

\section{COPPER.}

Copper minerals, mainly malachite and red oxide, appear occasionally in the granite, and in the vicinity of Bull camp and Okie's store considerable prospecting has been done. Small amounts of moderately high grade ores are obtained, mainly from quartz veins in the vicinity of the diabase dikes. The principal prospects are east and southwest of Bull camp, one of the most extensive being near Beaver Creek, 3 miles east-southeast of that place. Here a shaft has been sunk 40 feet, but only a small amount of copper ore was obtained. Apparently the mineral is in minute veins widely scattered through the rock, and no bodies of economic importance appear.

On a branch of South Fork of Wolf Creek, southwest of Walker Prairie, several efforts have been made to develop a copper mine in a 15-foot quartz vein in the granite. A shaft has been sunk 56 feet and crosscuts made. The ore is mainly malachite, occurring in irregular veins in the quartz. Some galena also occurs and part of the vein carries gold amounting to from $\$ 3.50$ to $\$ 4$ a ton. The quartz vein at this locality extends about 3 miles southwest and the same distance east of the opening, passing under Deadwood sandstones at Walker Prairie. Near its northeast end, at Walker's mine, where it is about 25 feet wide, it has been prospected to some extent. A small amount of pyrites was obtained which earried small values of gold. 
Copper minerals have been recently discovered in the granite area in the uplift of the Bridger Range, a few miles southwest of Deranch. 'One vein has been opened which shows a moderate-sized body of high-grade ore, consisting of oxides and sulphides. The openings.are not yet sufficiently developed to exhibit fully the extent and value of the deposit. As stated in the preceding paragraph, considerable gold occurs with the copper minerals of this locality.

\section{GYPSUM.}

The gypsum in the Chugwater formation, on both sides of the mountain, is of excellent quality, in every way suited for the production of stucco and plaster of Paris. This product is prepared by calcining and powdering the mineral, which is a combination of sulphate of lime and water. The beds of gypsum occur generally near the base of the formation and a thickness of 10 to 15 feet is usually presented. ${ }^{\circ}$ Much of the material is of pure white color and is nearly pure. Owing to the lack of a local market and the fact that the value of plaster of Paris is too low to cover freight charges for long shipments, this resource has no promise of development at present.

\section{BENTONITE.}

No bentonite has been observed in the immediate vicinity of the Bighorn Mountains, but as it occurs in adjoining areas and appears generally to be present in the Benton shale probably it will eventually be found. It occurs at two horizons, one below and the other above the hard shale or Mowry member. The mineral is a pale greenish-buff clay of compact texture and of such porous structure that it will absorb several times its bulk of water. On account of this absorbent quality it has a moderate market value for several uses.

\section{LIMESTONE.}

The limestones of the mountain slopes are in the main sufficiently pure for lime burning or for smelting flux, but there is very little demand for these products in the region. No analyses have been made to ascertain the chemical character of the rocks.

\section{BUILDING STONES.}

Many of the rocks in the mountain portion of the area are more or less well suited for building stone. Some of the granites are massive, have a fine appearance when polished, are relatively free from minerals which cause stains on weathering, and may at some time be valuable for shipment for building. Some of the limestones in the Madison formation are of very satisfactory texture and appearance and possibly could be worked for marble, especially the upper member. The Tensleep sandstone is usually massive, even textured, and of white or light-buff color, so that if nearer to markets it might be advantageously worked as a freestone. The red sandstones of the Chugwater formation are of a very pleasing color, but they are mostly too soft to be of value for building. Large supplies of rough stones for foundations and similar uses are obtainable from the Piney, De Smet, Parkman, and Cloverly sandstones and the hard ledges in the Sundance formation.

\section{PHOSPHATE.}

The spherical concretions occurring in the lower portion of the Benton formation ccnsist mainly of phosphate of lime, and as they could be obtained in large numbers by means of suitable excavating machinery they may at some time be utilized as a source of phosphate.

\section{PETROLEUM.}

At various localities along the sides of the Bighorn and associated uplifts some of the sandstones and sandy shales contain petroleum. This material usually appears in springs or' seeps in small valleys, and so far has been found only in limited amounts. The prin- 
cipal occurrences are on the sides of the uplift which rises east of South Fork of Powder River, in T. 38, R. 82, and T. 40, R. 79, the latter being in the valley of Salt Creek. Details regarding these occurrences are given in bulletins by the late Prof. W. C. Knight.a

Nine wells bave been sunk on Salt Creek to depths of from 800 to 1,200 feet, some of. which yield oil. The output of this field in 1905 averaged 35 barrels a day; which has to be hauled 50 miles to Casper at a cost of $\$ 2.80$ a barrel. It sells at an average rate of $\$ 7$ a barrel. The horizon appears to be sandstone at the base of the Pierre, or possibly the next sandstone stratum below, in the upper part of the Niobrara.

Oil springs of small volume occur in the vicinity of Bonanza, but a number of wells sunk in that field have failed to obtain a supply. The oil in the springs is from a horizon in the lower portion of the Benton.

\section{ASPHALTUM.}

A deposit of asphalt occurs in the Tensleep sandstone, on the west slope of the Bighorn Mountains, in secs. 28, 29, 32, and 33, T. 52, R. 89. The thickness is stated to be 6 feet, but the area has not been ascertained. The material consists largely of asphalt intimately mixed with coarse sand. 


\title{
MINERAL RESOURCES OF THE BIGHORN BASIN.
}

\author{
By Cassius A. Fisher.
}

\section{COAL.}

General description.-Coal is the principal mineral resource in the sedimentary formations of the Bighorn Basin. It occurs mainly in the so-called Laramie formation, although on the west side of the district a coal, said to be of good quality, is found in the upper part of the Colorado formation, and on No Wood Creek, 12 miles southeast of Bonanza, a deposit of coal is mined from the Cloverly formation. The coal is found at various horizons throughout the "Laramie" formation, but the most persistent beds of workable thickness are in a basal member of this formation, or possibly in lower beds. Coal is of widespread distribution within the area occupied by the Laramie formation. The greatest development, however, is found in places where the larger streams expose the coal measures. Here the most favorable conditions exist for locating mines, and the increased settlement of the irrigated valleys along the streams affords a local market for the coal. A detailed description of the coal deposits in the various districts where the principal development has taken place has already been published, $a$ but since this investigation was made several new mines have been opened and a. brief account of these is here given.

Cody Coal Company's mine:-During the winter of 1904 the Cody Coal Company opened a mine on the north side of Shoshone River, about 3 miles east of Cody station. The coal occurs about 1,500 feet above the base of the Laramie formation, in bed 5 dipping at an angle of $45^{\circ} \mathrm{E}$. It is about $4 \frac{1}{2}$ feet thick and is apparently of good quality, although no analysis of the product is available. The opening of this bed is in the face of the bluffs about 30 feet above the railroad, so that the coal can be loaded for shipment at a small expense when the new sidetrack now being built is completed. The mine is well timbered and preparations are being made for extensive development. A section of the deposit is as follows:

Section at Cody Coal Company's mine, Cody, Wyo.

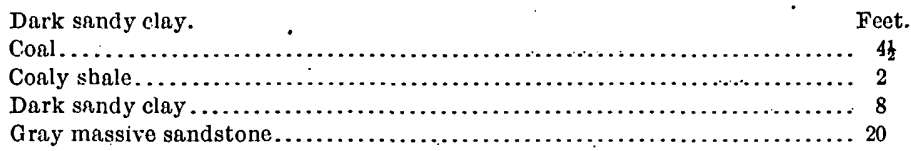

Arrangements are now being made by another company to mine conl at the same horizon on the south side of Shoshone River.

Silver Tip mine.-The deposit on Cottonwood Creek, on the north side of the divide between Clark Fork and Shoshone River, has been prospected at several places, but the principal opening, the Silver Tip mine, is in sec. 29 , T. 58, R. 100. Here considerable coal has been taken out for the last three year's, chiefly to supply the ranch trade of Clark Fork Valley. The total thickness of the bed is 5 feet, including two partings of impure coal and a thin layer of soft light-colored clay. The main entry is driven in about 125 feet from the outcrop and throughout this distance the character of the coal appears to be uniform. An analysis

a Fisher, Cassius A., Coal of the Bighorn Basin: Bull. U. S. Geol. Survey No. 225, 1904, p. 345. 
of this coal shows a moderate amount of fixed carbon and volatile matter, with relatively low percentages of water and ash. A section at the Silver Tip mine is here given:

Section at Silver Tip mine, on Cottonwood Creek, Wyoming.

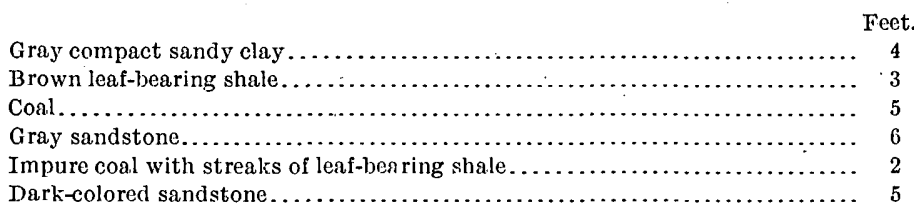

Woodruff mine.-During the summer of 1904 an opening was made on a bed of coal in the upper part of the Laramie formation near the mouth of Meeteetse Creek, about 2 miles north of Meeteetse, Wyo. The seam is 4 feet thick with no partings. It is overlain by hard gray sandstone and underlain by a dark-colored compact clay. An entry 150 feet deep has been driven on the seam, with several large rooms on either side. The coal is hard and black, with a bright luster. It appears not to break up badly on exposure, and as a domestic coal is said to be very satisfactory. No analysis has been made of this coal. During the past two years the Woodruff mine has had a total output of 2,200 tons, which sells at $\$ 2.25$ per ton. The coal finds a ready market at Meeteetse, Wyo.

Erskin mine.-Another mine, which is owned by Mr. Erskin, has recently been opened near Meeteetse, Wyo. It is located in sec. 13, T. 48, R. 101, about 21 miles above Meeteetse, in the lowland of Gray Bull Valley. This mine is on the same seam which has been worked for many years on the north side of Gray Bull River, known as the Edward Blake mine. The coal beds have a dip of $6^{\circ} \mathrm{E}$., and are somewhat thicker than on the opposite side of the valley. The output for last season during the period of development of the mine was about 700 tons.

No Wood coal.-An opening has been made in a coal bed which outcrops near the base of a prominent hill at the head of Bud Kimball Braw, 14 miles southwest of Tensleep, Wyo. Coal is not mined here regularly, but many of the settlers along No Wood Valley obtain their fuel supply from this place. The coal bed, which occurs in the lower part of the Laramie formation, has an aggregate thickness of about $6 \frac{1}{2}$ feet, consisting of four benches separated by partings of bony coal and brown leaf-bearing shale.

\section{Section of No Wood coal near head of Bud Kimball Draw, Wyoming.}

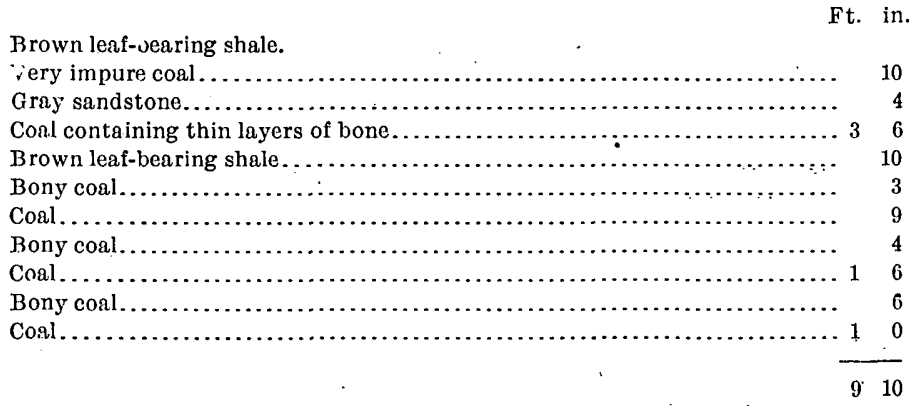

BENTONITE.

Bentonite deposits occur at various places throughout the Bighorn Basin. Those of most common occurrence are in the Colorado formation, being found at two or more geologic horizons. The thickest deposit observed is in a series of dark shaly beds about 100 feet below the Mowry beds. The bentonite at this horizon, in the northern part of the Bighorn Basin, has been described by the writer in a previous bulletin. $a$ During the last field 
at this place are about 15 feet thick and the product is of good quality. The material is ground and placed in ovens where it is calcined at a red heat in order to drive off the chemically combined water. A retarder is then added to prevent it from hardening too quickly when water is applied. After this it is mixed with hair and placed in barrels ready for shipment. The entire process of converting the gypsum into stucco is relatively simple and inexpensive. The finished product of this mill is sold at Bridger at $\$ 12$ a ton, but the output is not large.

An analysis of gypsum from the Chugwater formation near Bowler, Mont., was made by Mr. W. O. Dickinson, assistant in chemistry at the State University of Montana, as follows:

Analysis of gypsum from Chugwater formation near Bowler, Mont.

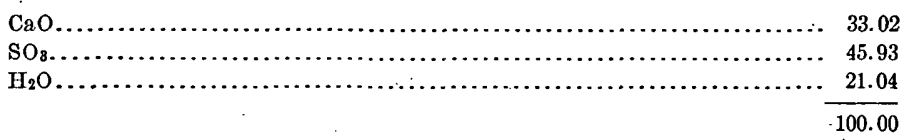

OIL AND GAS.

Several attempts have been made to obtain oil from the Cretaceous shales throughout the Bighorn Basin, but generally without success. About three-fourths of a mile southwest of Bonanza, near the axis and at the north end of an anticline in the Colorado formation, there are several oil seeps which furnish a small amount of oil. The oil is from a thinbedded sandstone under the Mowry beds of the Colorado formation. This surface indication has caused many persons to believe that oil in paying quantities might be obtained by drilling, and consequently several deep borings have been made in this region. None of these have been successful and at present all exploration has ceased. The oil from this locality has been analyzed by Prof. E. E. Slosson, of the University of Wyoming, and is reported to be of good quality, but the amount is too small to warrant development.

A deep boring for oil was made at the mouth of Cottonwood Creek, on Shoshone River, near Cody, Wyo., but no oil was obtained. The well is located on the west slope of a small anticline in Colorado formation.

Byron gas well.-Plans are now being made to sink a deep well on the west side of a broad anticline along the axis of which a small area of Pierre shale is exposed. Shoshone River crosses the south end of the anticline and has cut for some distance into the shale. In the low valley of this stream, near the center of the anticline, there are places where gas escapes in considerable quantity from the alluvial sands. It is probably derived from the underlying shales of the Pierre formation. The gas burns readily, but its quality was not ascertained. The boring which is now proposed will doubtless demonstrate whether or not gas is present in sufficient amount to warrant development.

About 3 miles east of Basin, Wyo., a small well is being dug in the Pierre shale for the purpose of finding gas. The present depth of the well is about 60 feet and an appreciable amount of gas has already been obtained. A small company has been organized and the work will be continued.

\section{MINERAL WATER.}

- Cody Hot Springs.-About 3 miles west of Cody, Wyo., in the bed of Shoshone River, there are a number of hot mineral springs. The water from these springs contains a large amount of hydrogen sulphide and probably some sulphuric acid. The temperature of the water is $98^{\circ}$. There is a sanitarium near the springs and the water is used for medicinal purposes.

Thermopolis Hot Springs.-At Thermopolis, on Bighorn River, in the southeastern part of the Bighorn Basin, there is a hot mineral spring the flow of which has been variously estimated at from 2,000 to 3,000 gallons a minute. Calcium carbonate is the principal ingredient of the water, while magnesium, sodium, and calcium sulphates are present in smaller 
amounts. An analysis of this water, made by Prof. E. E. Slosson, of the University of Wyoming, is here given:

Analysis of water of Thermopolis Hot Springs, Wyoming.

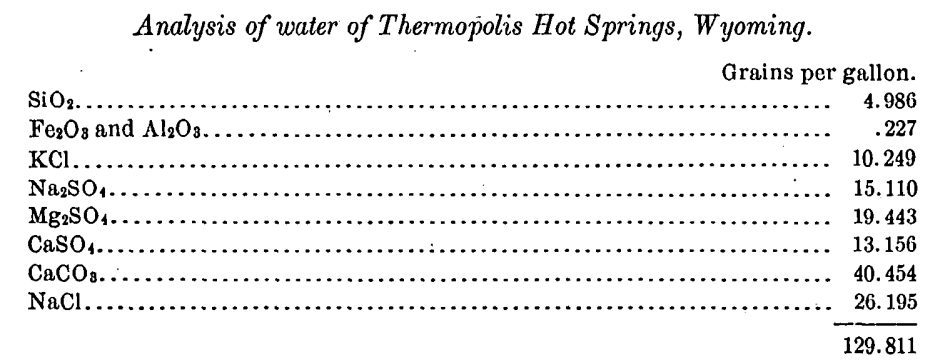

There are two sanitariums and a large plunge located near the spring and the place is rapidly becoming a popular health resort for the people of northwestern Wyoming.

\section{SULPHUR.}

Sulphur occurs in local deposits on the south side of Shoshone River, at the lower end of Shoshone Canyon, and along the west side of Sulphur Creek for about 2 miles above its mouth. It was deposited by heated waters and gas from the numerous geysers that once existed in this region. A large amount of prospecting has been done, with a view of developing this resource. The material appears to be of excellent quality and, if it occurs in suffciently large quantities, might be profitably worked. Sulphur also occurs in the hot-spring deposits at Thermopolis. 


\title{
THE NORTH DAKOTA-MONTANA LIGNITE AREA.
}

\author{
By A. G. Leonird. \\ LOCATION.
}

The North Dakota-Montana lignite area includes most of the western half of North Dakota, eastern Montana, and the adjoining parts of South Dakota and Wyoming; it also extends north into Canada. Lignite is known to occur as far west as Bighorn River and the mouth of Milk River in Montana and the Bighorn Mountains in Wyoming, or about 150 miles west of the North Dakota line. . In South Dakota the lignite is confined to the northwest corner of the State. Farther west the lignite field extends south into Wyoming, where it includes portions of Sheridan, Johnson, Crook, and Weston counties. The area has an extent of about 350 miles east and west and at its widest part nearly the same extent north and south, containing approximately 100,000 square miles. This is over twice the area of New York State and is about equal to that of Colorado. North Dakota and Montana each includes about 40,000 square'miles of the total area.

\section{TOPOGRAPHY.}

The topography of by far the greater portion of this extensive region is that of a gently rolling or rough plain which has an elevation of from 2,000 to nearly 3,000 feet above sea level. Rising above the general level of this plain and forming conspicuous features of the landscape are numerous flat-topped buttes and hills. Slim Buttes and Cave Hills in South Dakota and Sentinel Butte, Bullion Butte, and the Killdeer Mountains in North Dakota are notable examples. They rise abruptly from 400 to 600 feet above the plain. The buttes are especially characteristic of the eastern part of the region, in North and South Dakota.

On the northern and eastern borders of the lignite area the surface has been modified to a considerable extent by the continental ice sheet, which left behind a mantle of bowlder clay, sand, and gravel that forms a gently rolling plain. This drift plain is found east and north of Missouri River and extends 50 miles and more south and west of that stream.

A striking contrast to the flat, wide prairies is furnished by the extremely rough badland areas bordering the streams and frequently extending back from them many miles. The bad lands are perhaps best developed along Little Missouri and Yellowstone rivers, though they are by no means confined to the vicinity of these streams.

The lignite area is traversed by several rivers of importance, whose broad, deep valleys form conspicuous topographic features, besides affording favorable routes for railroads. Those of the Missouri and Yellowstone are the most extensive, being from 200 to 300 feet deep and from 1 mile to several miles wide; of less importance are the valleys of Little Missouri, Tongue, and Powder rivers.

\section{STRATIGRAPHY.}

Pierre shale.-All the rocks exposed in the lignite area belong to the Cretaceous system. Those immediately underlying the coal-bearing beds belong to the Pierre shale, which also borders the "Laramie" $a$ or coal-bearing formation on the east and south. The bluish-gray,

. a In conformity with common usage in the North Dakota field, the term Laramie is here used for the lignite-bearing beds, although it is recognized that the name Fort Union may be more appropriate. 
jointed shales of this formation are brought to the surface by an anticline along Yellowstone River 12 miles above Glendive, Mont., at the mouth of Cedar Creek. The Laramie beds on the south side of the creek have a dip of $25^{\circ} \mathrm{SW}$., while on the north side of the creek valley occurs the Pierre shale with many characteristic fossils. There are here 200 feet of dark shale overlain by 150 to 200 feet of light-buff shale. Scattered through these beds ure abundant siliceous and ferruginous nodules of lime carbonate, of ten rich in fossils. The fossil-bearing nodules are most numerous toward the top of the dark shale, in a horizon 250 to 300 feet above the river. The Pierre strata are seen outcropping in the bluff's of the Yellowstone for a distance of at least 5 or 6 miles. Shale similar in appearance and with many of the same Pierre fossils occupies an area of considerable size in western Bowman County, N. Dak., and extends across the line into Montana. This belt stretches many miles north and south on either side of the boundary line and has a width of from 3 to 10 miles or more. It is not unlikely that the Pierre outcrops at other points within the lignite area, but the above were the only localities found during the past season.

Fox Hills sandstone.-At some localities the Fox Hills sandstone lies between the Pierre and Laramie formations, but generally it is absent in this field. Outcrops of this formation are extremely rare, the only one known being in Morton County, N. Dak., on Cannon Ball River. About 8 miles above the confluence of this river with the Missouri a brown, ferruginous, friable sandstone occurs containing Tancredia americana M. \& H. and Callista sp., possibly Callista nebrascensis M. \& H. These fossils were identified by T. W. Stanton, and doubtless are of Fox Hills age.

- Laramie formation.-The lignite occurs ia the Laranie beds, which show remarkable uniformity in character over the entire region. They are composed of semiconsolidated sands and clays, the sand being in some places cemented into a more of less firm sandstone. In certain localities sandy strata predominate; in others clay and sandy clay constitute the bulk of the formation. The character of the Laramie formation is shown by the following sections:

\section{Section in the bluffs of the Little Missouri at Meilora, N. Dak.a}

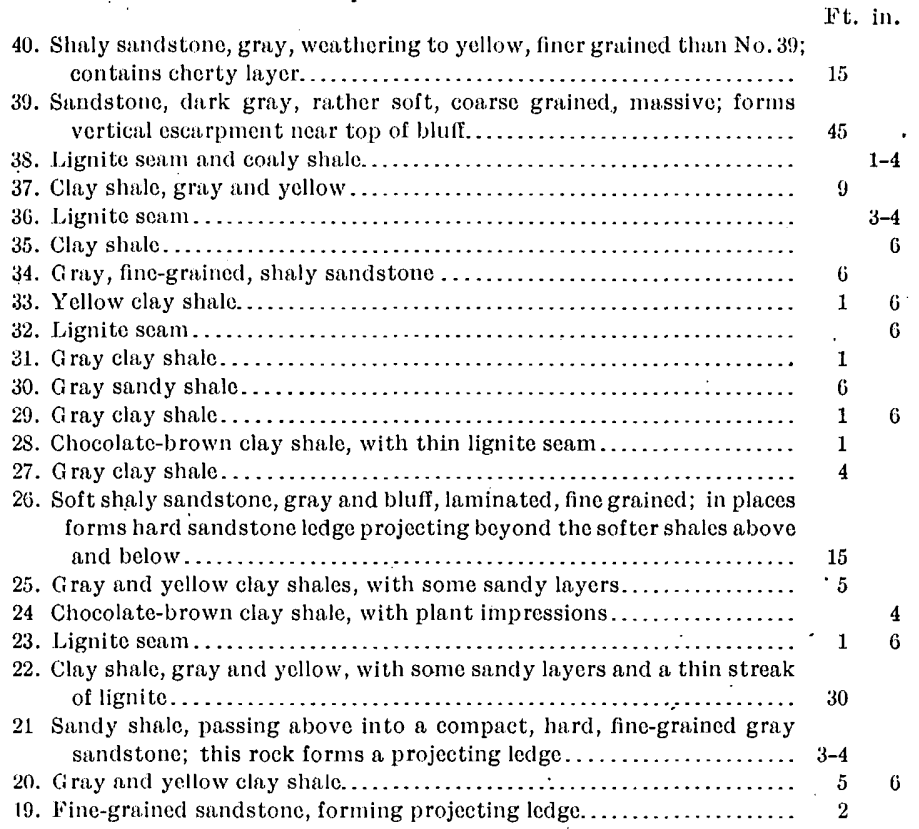

a'Third Bienn. Rept. Gicol. Survey North Dakotat, pp. 161-162.

Bull. 285-06-21 
18. G ray and yellow clay shale.

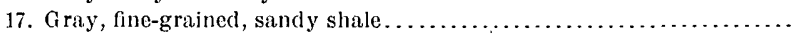

16. Lignite streak and chocolate-brown shale. . . . . . . . . . . . . . . . .

15. Gray sandy shale and soft sandstones; in places the sandstone is cemented into hard rock, forning projecting ledge. . . . . . . . . . . . .

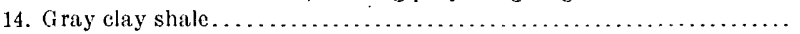

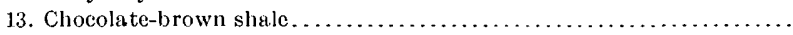

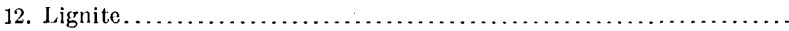

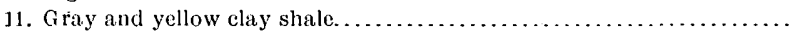

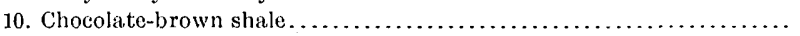

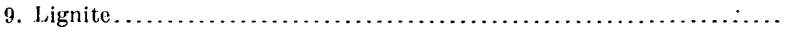

8. Chocolate-colored clay shale with abundant plant remains, mostly

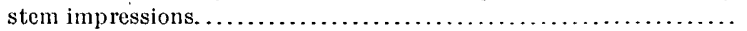

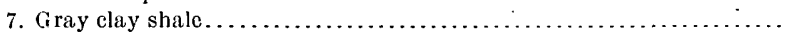

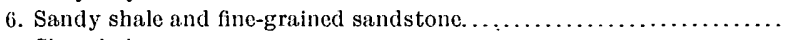

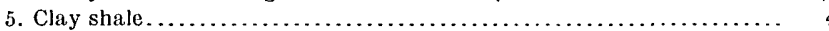

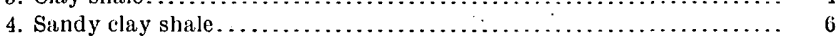

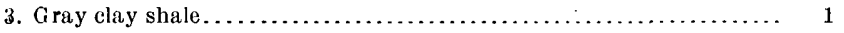

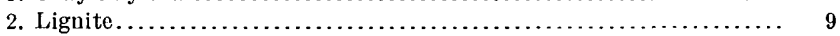

1. Gray clay shale, not well exposed, to river. $\ldots \ldots \ldots \ldots \ldots \ldots \ldots \ldots \ldots$

The beds constituting the top of the Laramie are exposed in Sentinel Butte, where the section given below is shown:

\section{Section at Sentinel Butte; North Dakota.a}

29. Alternating layers of highly calcareous gray clay and very fine-grained, compact, brittle, gray limestone, finely laminated, and more or less siliceous. Some of the sandstone beds weather into thin lamina,

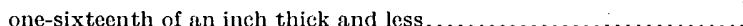

28. Very calcareous gray clay, weathering to a greenish color .............

27. Gray hard sandstone.................................... 40-50

26. Gray and yellow sandy clay............................... 25

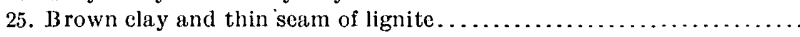

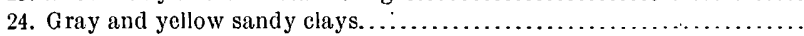

23. Lignite.

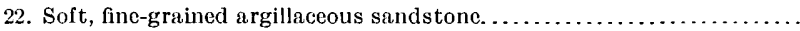

21. B rown and gray clay shale containing many selenite crystals ........

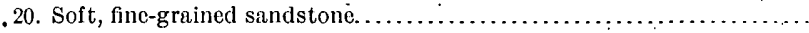

19. Lignite.

Ft. in.

18. Chocolate-brown clay shale, with carbonized wood ................

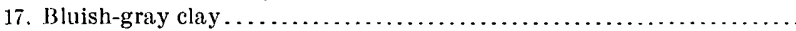

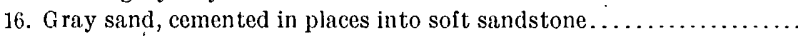

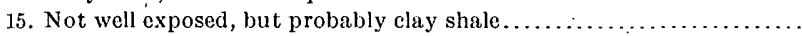

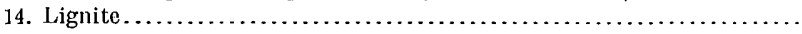

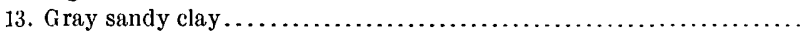

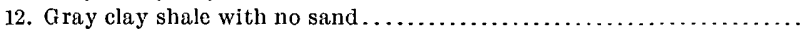

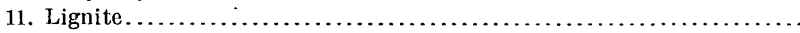

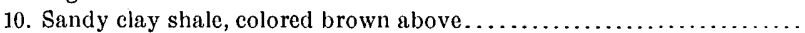

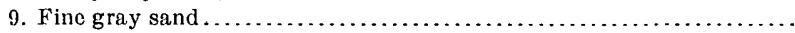

8. Gray sandy clay shale, containing nodules, similar to No. $6 . \ldots \ldots \ldots$.

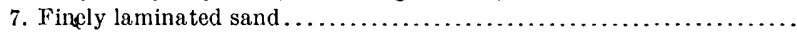

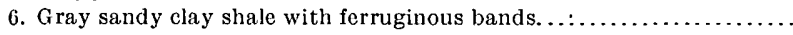

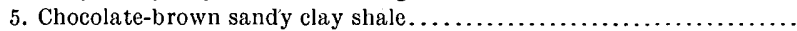

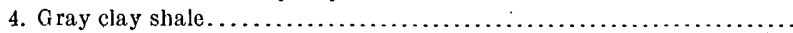

3. Sandy gray clay, containing abundant siliceous iron nodules, arranged mostly in bands at certain horizon. These hard nodules project from the surface of the softer clay and also cap small clay columns.

2. Unexposed; ineludes some sand..............................

1. Lignite, outcropping in bottom of ravine near the east end of the butte, exposed

Nos. 28 and 29 of the above section are probably Tertiary. 
The number of lignite seams which may be present in a single section is well exhibited in the bluffs of Little Missouri River 5 miles above the mouth of Cherry Creek, in northwestern Dunn County, N. Dak.

Section on Little Missouri. River 5 miles above Cherry Creek.

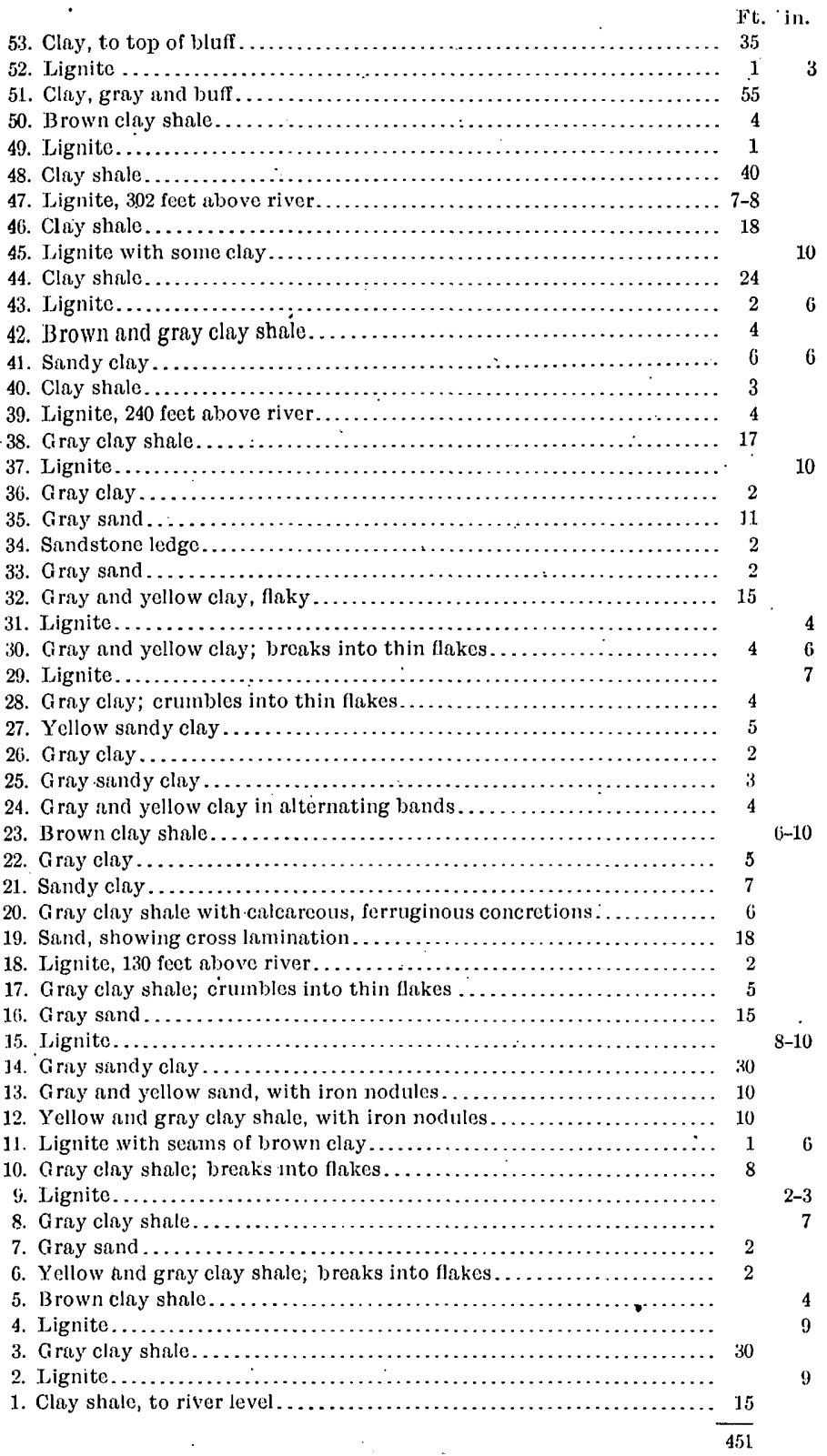

In southeastern Custer County, Mont., the Laramie formation is made up very largely of an indurated sandstone occurring in massive ledges and with a thickness of from 1.50 . to 300 feet. Thij sock is finely exposed along Big Box Elder Creek, where it forms verticial 
cliff's bordering the valley, and in the Long Pine Hills in the vicinity of Camp Crook, S. Dak. $\Lambda$ the Mill Iron ranch, on Big Box Elder Creek, about 10 miles above the boundary line, the siudstone is well shown in the following section:

Section at Mill Iron ranch, on Big Box Elder Creek, Montana.

\begin{tabular}{|c|c|c|}
\hline 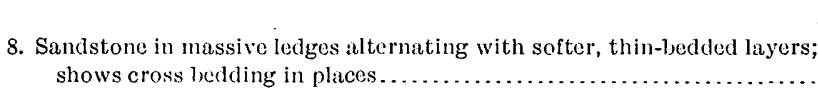 & 160 & \\
\hline 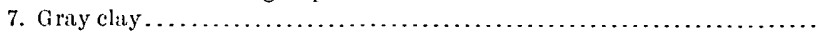 & (i & \\
\hline 6. Jignite & 1 & 2 \\
\hline 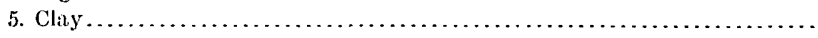 & & 10 \\
\hline 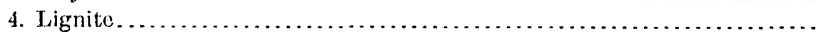 & & 10 \\
\hline 3. Clay & 5 & \\
\hline 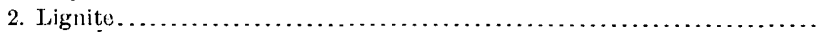 & 1 & 6 \\
\hline 1. Unexposed to creek. . . . . . . & $4 \dot{5}$ & \\
\hline
\end{tabular}

This thick sandstone was found to extend southwird for 30 miles to the Long Pine Hills. In these hills the arenaceous strata have a thickness of from 250 to 275 feet, the rock being gray and yellow and weathering unevenly into a variety of fantastic forms. Many of the higher buttes of North and South Dakota are capped with sandstone beds belonging to the Laramie and having a thickness of 50 to 75 feet and over.

The foregoing sections may be taken as representative of the Laramie formation. They show that it is composed of alternating beds of clay and sand, together with seams of lignite. In places the sand layers are cemented into a firm, hard sandstone, but commonly they form incoherent beds, readily crumbling in the hand. These arenaceous strata, however, resist the action of weathering agencies better than the clays, and their outcropping edges form vertical ledges, of ten projecting beyond the clays. The presence of the sandy beds can thus commonly be detected at a distance by the character of the slope.

Probably two-thirds of the thickness of the Laramie is made up of clays, though this varies in different places. These clay shales range in composition from very pure clay through beds containing an increasing percentage of sand to those with only a small proportion of cliay. The argillaceous strata thus graduate into the sandy liayers through every intermediate mixture of clay and sand, and we have sindy clays and cliayey sandstones. Many of the so-called clays are, strictly speaking, impure sinndstones. In some cases the change from clay sliale to sand is abrupt; in others it is gradual, the clay becoming more sandy near the line of contact.

One of the most marked features of the Laramie is this ripid alternation of sand and clay strata and the frequent occurrence of beds of lignite. The colors of the clay are white, gray, yellow, brown, and red, the grays and yellows predominating. The brown layers are rich in plant remains, and it is to the presence of this carbonaceous matter that they owe their color. These varied colors give the formation its banded appearance and add greatly to the beauty and variety of the landscape.

Crystallized gypsum or selenite is common in the clay. It is particularly liable to occur in the brown layers immediately beneath the lignite seams. The crystals are often very much elongated, some being found 8 and 10 inches in length, and are seldom perfect, the faces being more or less etched.

Of still more frequent occurrence are ferruginous nodules and concretions, composed either of iron pyrites or of limonite. They usually contain more or less siliceous or argillaceous material, and after exposure to the weather stain the clay about them yellow. Many of the clay slopes are thickly dotted with these nodules and concretions of all shapes and sizes up to several feet in diameter. Thin, impure limonite or clay ironstone bands, yellow in color, are not uncomimon in the clays.

Another feature of the Laramie clays and sands which can not fail to attract the notice of even the casual observer is the great quantity of burnt and fused clay which is seldom 
alsent wherever there are extensive outcrops of the beds. This red clay has been produced by the heat generated by the burning of the seams of lignite, which has doubtless been going on ever since the formation of the seams. Bands of this material may be traced for many miles along the bluft's of the stream valleys and in the buttes representing the horizons of burned-out lignite seams, portions of which are often found intact at some points.

The Laramie beds have a thickness of at least 1,800 feet in the western part of North Dakota. The Medora well, 941 feet deep, did not pass through them, and Sentinel Butte rises 860 feet above the curb of the well. This is perhaps the maximum thickness of the formation in North Dakota and it grows thinner toward the enst until it is only a few hundred feet and less beyond Missouri River.

Tertiary.-The youngest strata occurring in the lignite area are certain beds which are referred to the Tertiary. These form the upper strata of the Slim Buttes and East and West Short Pine Hills of South Dakota, the Long Pine Hills of Montana, and the low mownd on top of Sentinel Butte, North Dakota. The beds consist mostly of fine-grained, white, soft sandstone, with some calcareous clay and limestone. Their thickness in the Slim Buttes is 200 to 240 feet, and in the East Short Pine Hills they attain nearly 300 feet. The white sandstone forms conspicuous clifts toward the top of the buttes, which can be seen from a great distance.

\section{LIGNITE.}

Interstratified with the sands and clays of the Laramie are seams of lignite. These are not confined to any particular horizon or horizons, but are distributed quite uniformly from top to bottom of the formation. In the Slim Buttes of South Dakota a 5-foot seam occurs 95 feet from the top of the Laramie. The $21 \frac{1}{2}$-foot seam in Sentinel Butte lies 340 feet below the top, and there is an 18-inch seam 142 feet below the same horizon. On the other hand, the records of deep wells at Medora and Dickinson show that the lignite is found toward the base of the formation. The seams thus have a vertical range of 1,500 feet or more.

The number of seams varies considerably in different parts of the field. At some points but two or three seams appear, while in other localities there are ten or fifteen in a vertical distance of from 250 to 500 feet, though many of them are only a few inches in thickness. Rarely are several hundred feet of Laramie strata exposed without one or more lignite beds. In the section already given (p. 319) appearing in the blufts of the Little Missouri neir the mouth of Cherry Creek, there are no less than fifteen seams within a vertical range of 480 feet, having an aggregate thickness of 25 feet. In the Third Creek district, 8 miles north of Glendive, Mont., four lignite seams, 7, 8, 10, and 14 feet thick, respectively, occur in a vertical distance of 200 feet, their aggregate thickness being 39 feet. In the 180 feet of Laramie clays exposed in the bluft's on the south side of Missouri River 3 miles below Williston the thickest of the six seams present is only 2 feet and the aggregate thickness is less than 3 feet. The Medora well passed through 941 feet of Laramie strata without reaching their base and encountered seventeen seams with a total thickness of more than 60 feet. The Dickinson well, with a depth of about 1,075 feet, penetrated sixteen seams, their aggregate thickness being about 55 feet. $a$

The lignite seams vary in thickness from an inch and less to 33 feet. Seams 6, 8, or 10 feet thick are common; seams from 10 to 20 feet thick are not rare, but those over 20 feet thick seldom occur.

The seams are usually not continuous over very large areas. $\Lambda$ particular seam will pinch out within a mile or two and perhaps be replaced by another at about the same or a different horizon. Two seams may overlap each other and, while both appear at one

a Darton, N. H., Preliminary report on artesian waters of a portion of the Dakotas: Seventeenth Ann. Rept. U. S. Geol. Survey, pt. 2, 1896, p. 663 . 
point, at another half a mile or so. distant but one of them is present. It is frequently not possible to correlate seams on the opposite sides of the same valley and only 1 or 2 miles apart. On the other hand, some seams can be traced 3 or 4 miles in the river blufts and less commonly twice that distance, but sooner or later they thin out and disappear. This lack of persistence makes it unsafe to correlate lignite beds whose outcrops are separated by more than a few miles.

The lignite differs considerably in appearance and physical properties in different parts of the region, though it is remarkably uniform over extensive areas. In North and South Dakota it is usually brown in color and more or less woody in character, exhibiting clearly the grain of the wood and having the toughness of the same material. It is difficult to break this lignite except along the grain, but it splits or breaks readily in that direction. Often portions of flattened tree trunks or branches are found in the seam, resembling much the original wood except.for their brown color. The same seam is frequently more woody in some portions than others, being made up of alternating bands of tough brown lignite and black, lustrous, more brittle material. The lignite changes.in character toward the west and in Montana much of it is black and lustrous, with little of the woody texture and appearance characterizing it in North Dakota, while it is almost as brittle as bituminous coal. This is much easier to mine than the tough brown variety, since it breaks up readily with the pick or in blasting. The lignite in the 9-foot seam at Medora and the $21 \frac{1}{2}$-foot seam in Sentinel Butte is woody and brown from top to bottom; that in the 12-foot seam on Beaver Creek, near Wibaux, Mont., is mostly black and lustrous, with only a few brown layers; while the lignite in the vicinity of Glendive is wholly of the black, brittle variety.

When exposed to the air for a short time the lignite loses much of its moisture and crumbles into small fragments. For this reason it is very desirable that the conl be used as promptly as possible after it is mined, before it has time to disintegrate, or "slack."

The chemical composition of the lignite is shown in the following analyses. The first was made at the United States Geological Survey coal-testing plant at the Louisiana Purchase Exposition and reported in Bullețin No. 261. The other analyses are taken from the Second Biennial Report of the North Dakota Geological Survey.

Anälyses of lignite from North and South Dakota.

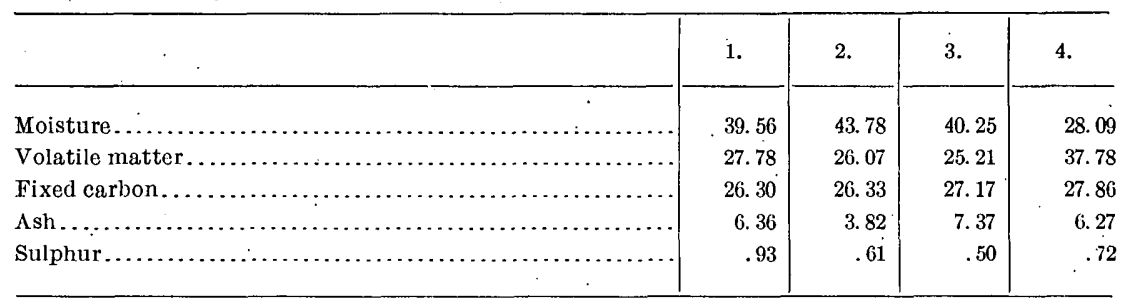

1. From mine of Cedar Coulee Coal Company, near Williston, N. Dak.

2. From 33-foot seam on Sand Creek, at Russell ranch, Billings County, N. Dak.

3. From 9-foot seam on Riley ranch, at the base of the Cave Hills, Butte County, S. Dak.

4. From 7-foot seam near Cartwright, Allred County, N. Dak. 
In the following analyses the fixed carbon, volatile matter, and ash are computed on a dry basis:

Analyses of lignite from various mines in North Dakota.

\begin{tabular}{|c|c|c|c|c|}
\hline Mine and location. & $\begin{array}{l}\text { Fixed } \\
\text { carbon. }\end{array}$ & $\begin{array}{l}\text { Volatile } \\
\text { matter. }\end{array}$ & Ash. & $\begin{array}{l}\text { Mois- } \\
\text { ture. }\end{array}$ \\
\hline \multicolumn{5}{|l|}{ Mouse River Lignite Co., Burlington: } \\
\hline 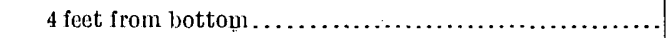 & 51. 28 & 35.83 & 11.89 & 32.00 \\
\hline Top $\ldots \ldots \ldots \ldots \ldots \ldots \ldots \ldots \ldots$ & 46.42 & .32 .60 & 20.98 & 30.00 \\
\hline 16 inches above clay seam..... & 47.36 & 42.14 & 10.50 & 29.40 \\
\hline Lower 20 inches.............. & 52.96 & 38.93 & 8.11. & 34: 70 \\
\hline \multicolumn{5}{|l|}{ Electric mine, Kenmare: } \\
\hline 4 feet from floor . .............. & 57.95 & 34.41 & 7. 64 & 32.90 \\
\hline 3 feet from floor........... & 59.19 & 36.56 & 4.25 & 35.00 \\
\hline Bottom ...................... & 56.58 & 34.44 & 6.98 & 34.8 \\
\hline 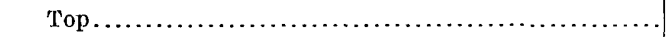 & 56.87 & 36.58 & 6.55 & 34.8 \\
\hline \multicolumn{5}{|l|}{ Diamond mine, Kenmare: } \\
\hline 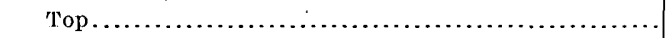 & 52.98 & 37.24 & 9. 78 & 33. 00 \\
\hline Center.................... & 56.82 & 33.77 & 9.41 & 33.00 \\
\hline Lower 18 inches ............................ & 56.97 & 36.28 & 6.75 & 33. 60 \\
\hline Dakota Lignite and Brick Co., near Burlington.... & 55.61 & $40.08 \cdot$ & 4. 30 & .23. 40 \\
\hline New Era mine, near Minot............................ & 57.66 & 38.22 & 4. 12 & 33.6 \\
\hline \multicolumn{5}{|l|}{ Sinith-Kenmare Dry Coal Co.: } \\
\hline Next to clay ................... & 55.55 & 36.79 & 7.67 & 33.2 \\
\hline Next to roof............... & 52.30 & 39.90 & 7.80 & 32.00 \\
\hline 1 foot below roof............. & 55.25 & 33.50 & 11.25 & 32.60 \\
\hline W fıdeson mine, Sims............ & 50.47 & 39.21 & 1.0. 32 & 30.29 \\
\hline 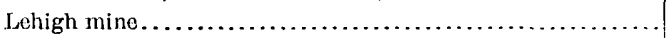 & 51.62 & 43. 18 & 5.21 & 34.3 \\
\hline Satterlund mine, near Washburn.... & 55.89 & 37.50 & 6.61 & 30.91 \\
\hline Washburn mine, Wilton.............. & 54.93 & 38.75 & 6.32 & 31.82 \\
\hline Dickinson Brick Co.................. & 46.89 & 38.23 & 14.88 & 27.82 \\
\hline Heart River, near Dickinson. ......................... & 60.49 & 38.31 & 1.20 & 14. 25 \\
\hline Consolidated Coal Co., New Salem ....................... & 53.80 & 41.66 & 4. 48 & 27.48 \\
\hline
\end{tabular}

Tests of the lignite as a gas producer were carried on at the coal-testing plant at the Louisiana Purchase Exposition, and the results, which are embodied in Bulletin No.261, show that the lignite is an exceptionally good gas-producer fuel. It would be ideal for the purpose except for the tendency to clinker.

Lignite in the Little Missouri River basin south of Medora, N. Dak.-The coal seams described under this heading outcrop in the valley of the Little Missouri and its tributaries, the area within which they occur extending 50 miles south of the Northern Pacific Railway. Lignite is abundant in this district, and the seams are both numerous and thick. Four or five workable beds are occasionally present in a vertical distance of 200 feet. Seams 6,8 , or 10 feet thick are of common occurrence, while several beds with a much greater thickness are found. The seams will be described in the order of their appearance from Medora up the river.

Near the base of the bluffs at Medora, at an elevation of 40 feet above the river, is a 9 foot seam which has been mined for a number of years. Thirty-one feet above this is an upper seam 4 feet thick. Five miles south of Medora, at the Custer Trail ranch, two 5-foot seams outcrop in the bluffs on the east side of the valley, one 75 and the other 130 feet above the river. Four and a half miles farther up the river a seam of lignite 15 feet thick outcrops in a cut bank just above water level. It contains several clay bands, including one 12 inches thick near the top of the seam. Lignite is mined here by the ranchmen of the vicinity, but the mine is difficult of access except in winter, when teams may be driven to it on the ice. Still farther up the river, on the Hanley ranch, about 3 miles below the mouth of Third Creek, 6 to 8 feet of lignite are exposed in the bluff along the Little Missouri. 
On Third Creek lignite appears at many points. About 4 miles above its mouth, near the McLellan ranch, in sec. 4, T. 136 N., R. 101 W., the following section is exposed:

Section of lignite at McLiellan ranch, on Third Creek.

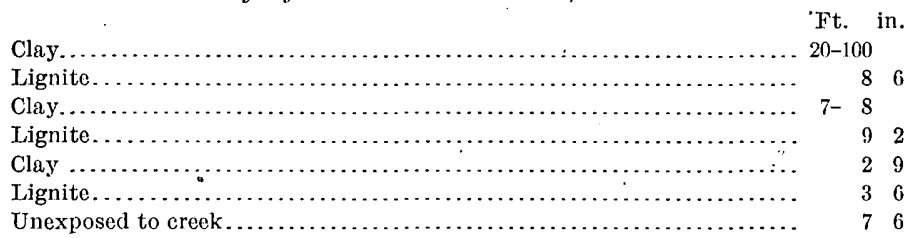

These three seams outcrop continuously for over 200 yards and have a slight dip to the east. The lowest one contains thin clay layers, but the lignite of the upper beds is of excellent quality. Seven or eight miles south of this point, on a small tributary of Sand Creek, three seams of lignite occur at approximately the same horizon as those found on Third Creek and are doubtless to be correlated with them. The following section is shown:

Section of lignite near Sand Creek.

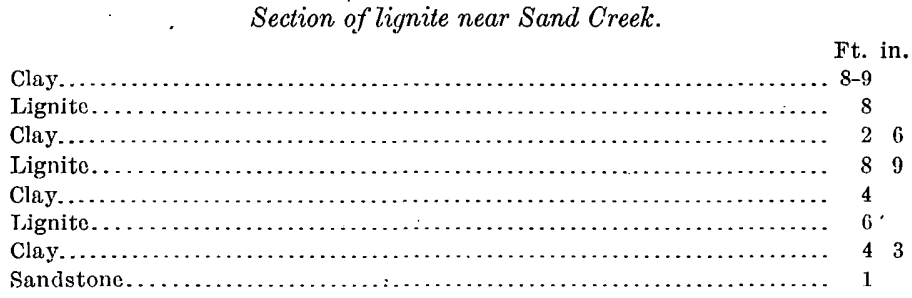

The seams exposed in the above section have burned out extensively, and the red, burnt clay thus formed covers large areas in several townships. At about the same horizon as this burnt clay is the thick lignite seam exposed on Sand Creek at the Russell ranch in sec. 31, T. 135 N., R. 101 W. The section shown here is as follows:

Section of lignite at Russell ranch on Sand Creek.

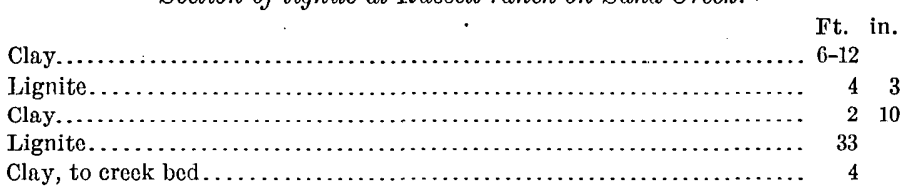

The lignite lies quite near the surface, and over large areas it has been eroded by Sand Creek and its tributaries, or burned, as stated above. This same seam appears along the creek from one-fourth to one-half mile to the south, and probably underlies a wide area on both sides of Sand Creek Valley. The 33-foot seam shown in the above section is, so far as known, the thickest which occurs in the entire lignite region of North Dakota and Montana. It has been reported to have a thickness of 40 feet, but careful measurement showed it to be 33 feet, though if the upper seam and the clay bed between are included the total would be 40 feet. There is reason to believe that the seams outcropping on Sand Creek are to be correlated both with those exposed 7 or 8 miles north and west on the tributary of the same creek and with those still farther north on Third Creek. If this correlation is correct, these thick seams cover an area at least 15 miles long from north to south and with a width probably as great. Other beds of lignite occur at several points farther south on Sand Creek. 
In that part of the valley of the Little Missouri which has an east-west course for many miles a 1.3-foot seam is exposed not far from the mouth of Deep Creek. Many lignite seams occur above this point in the vicinity of Yule. In the river bluffs about 2 miles below the post-office, on the east side of the valley, three seams are present, as shown in the following generalized section:

Generalized section 2 miles below Yule.

Feet.

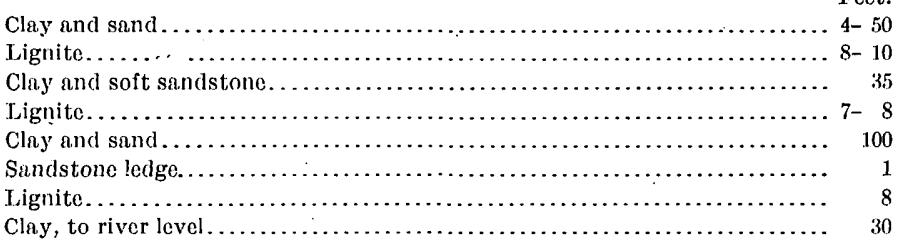

The lower seam outcrops at several points in the cut banks on both sides of the river for a distance of 2 or 3 miles. The two upper seams are exposed in the badlands bordering the valley on the east. Along the river above Yule a 10-foot seam of lignite occurs near water level and can be traced for several miles. It has been mined and used by those living in the vicinity, but can not be reached except in winter, when the river is frozen. Above this bed there are two others $2 \frac{1}{2}$ and 3 feet thick, respectively. A second 10 -foot seam is exposed near the top of the bluff 1 mile south of Yule, on the west side of the valley. Two and one-half miles southwest of the place just described another bed of lignite 10 feet thick occurs at the mouth of Deer Creek, at an elevation of 55 feet above the river. This seam outcrops at various points for a mile or more along the valley of the creek. In a ravine entering Little Missouri Valley 2 miles above the mouth of Deer Creek, in sec. 16, T. 135 N., R. 105 W., six seams are exposed within a vertical distance of 165 feet, as follows:

Lignite beds 2 miles above mouth of Deer Creek.

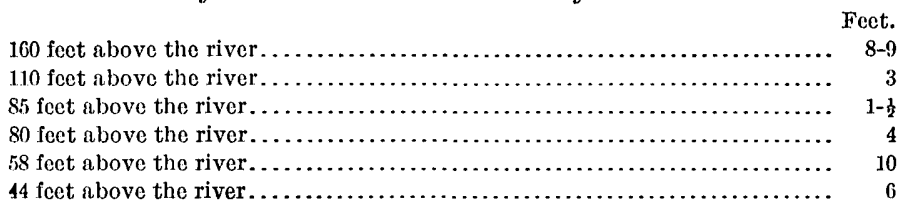

On Cash Creek, which enters the Little Missouri from the east about 12 miles above Yule, a lignite seam 8 feet thick is exposed near the J. S. Blue ranch.

Lignite occurs on Bacon Creek, a tributary which flows eastward near the southern border of Billings County: A seam with a thickness of at least 29 feet is mined at the T-Cross ranch about 7 miles above the mouth of the creek. The lignite outcrops in the side of the valley near the ranch buildings and is overlain by 8 to 10 feet of clay. The bottom of the seam is not exposed, and the thickness given above is only that portion which lies above the bed of the stream. Eight miles to the southeast, in Bowman County, another thick seam occurs at the Dukorn \& Gamble ranch on Coyote Creek. The entire thickness could not be measured, since the bottom was concealed by talus, but 12 feet of lignite are exposed.

In Bowman County the bluff's bordering the Little Missouri rise only about 80 feet above the river and are for the most part covered with vegetation. Outcrops are therefore scarce, but where the river has cut into the bluff, forming steep, bare cliffs, no lignite seams occur. From the data at hand it seems that there is little or no lignite along the river in this county.

Lignite along the valley of Little Missouri River between Medora and Missouri River.Throughout this region the beds are so nearly horrizontal that the river channel falls continually lower with respect to particular horizons as it extends to the north. In the vicinity of 'Medora the bluf's are from 200 to 300 feet high, while north of the Killdeer Mountains the level of the upland plain is between 500 and 600 feet above the river. On 
account of this horizontality of the rocks and the descent of the stream, the beds of lignite which were observed occur in various parts of the stratigraphic column. Although they are scattered through the great mass of sediments somewhat irregularly, there appear to be six distinct horizons at which considerable quantities of lignite were seen. These are shown in the following table:

Lignite seams along the valley of Little Missouri River between Medora and Missouri River. a

\begin{tabular}{|c|c|c|c|c|c|}
\hline Location of outcrop. & $\begin{array}{l}\text { Thick- } \\
\text { ness of } \\
\text { seam. }\end{array}$ & $\begin{array}{l}\text { Eleva- } \\
\text { tion of } \\
\text { out- } \\
\text { crop } \\
\text { above } \\
\text { river. }\end{array}$ & $\begin{array}{l}\text { Materials } \\
\text { above and be- } \\
\text { low lignite. }\end{array}$ & Extent of outerop. & Remarks. \\
\hline $\begin{array}{c}\text { Group } \Lambda . \\
\text { Medora } \ldots \ldots \ldots \ldots \ldots \ldots \ldots .\end{array}$ & $\begin{array}{r}\text { Feet. } \\
8\end{array}$ & $\begin{array}{l}\text { Feet. } \\
50-60\end{array}$ & $\ldots \ldots \ldots \ldots$ & 7 rods........ & $\begin{array}{l}8 \text { seams of coal re- } \\
\text { ported from this } \\
\text { point. }\end{array}$ \\
\hline $\begin{array}{l}4 \text { miles north of Medora; } \\
\text { Burgess's ranch. }\end{array}$ & 10 & 225 & Clay........... & 2 rods $\ldots . . . \ldots \ldots$ & $\begin{array}{l}\text { This seam proba- } \\
\text { bly above those } \\
\text { at Medora. }\end{array}$ \\
\hline $\begin{array}{c}\text { Burgess's } \ldots \ldots \ldots \ldots \ldots \ldots \ldots \\
\text { GROUP в. }\end{array}$ & $1-5$ & $100 \pm$ & & $\therefore \ldots \ldots \ldots$ & $\begin{array}{l}\text { Probably the same } \\
\text { as at Medora. }\end{array}$ \\
\hline Opposite Burgess's house... & $3-8$ & $0-16$ & Clay .......... & Several rods..... & \\
\hline 5 miles below Burgess's . . . . . & $3-5$ & $20-30$ & $\begin{array}{l}\text { Clay and sand- } \\
\text { stone. }\end{array}$ & $\begin{array}{l}\text { At intervals for } \\
\text { miles. }\end{array}$ & Strata undulating: \\
\hline Near Young's ranch......... & $2-4$ & $40-60$ & Clay .......... & Seen in ravines... & 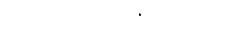 \\
\hline $\begin{array}{c}\text { Between Young's and John- } \\
\text { son's. } \\
\text { GRouP c. }\end{array}$ & & $\ldots \ldots$ & $\ldots \ldots \ldots \ldots \ldots$ & $\ldots \ldots \ldots \ldots \ldots \ldots$ & Several thin seams. \\
\hline 3 miles south of Mikkleson... & 2 & 0 & $\begin{array}{l}\text { A llu vi u m } \\
\text { above. }\end{array}$ & $1-2$ miles.......... & $\begin{array}{l}\text { Probably other } \\
\text { seams cut away } \\
\text { above by the } \\
\text { river. }\end{array}$ \\
\hline 1 mile south of Mikkleson... & 16 & $(b)$ & $\begin{array}{l}\text { Cla } y-t h \text { in } \\
\text { covering. }\end{array}$ & 50 rods........... & $\begin{array}{l}\text { Lowest seam may } \\
\text { be equivalent to } \\
\text { one } 3 \text { miles south } \\
\text { of Mikkleson. }\end{array}$ \\
\hline $2 \frac{1}{2}$ miles below Mikkleson.... & 16 & 2 & Clay ........... & $\begin{array}{l}15 \text { rods (1 mile be- } \\
\text { low, } 10 \text { rods) }\end{array}$ & $\begin{array}{l}\text { Coal is burned in } \\
\text { many places. }\end{array}$ \\
\hline $\begin{array}{l}\text { Read's ranch, 7-8 miles north } \\
\text { of Mikkleson. }\end{array}$ & $\begin{array}{r}c 4 \\
d 6-7\end{array}$ & $\begin{array}{r}60 \\
50-60\end{array}$ & Sandy clay ... & $\left\{\begin{array}{c}\frac{1}{2} \text { mile; all bluffs } \\
\text { along the river } \\
\text { below Mikkleson }\end{array}\right\}$ & $\begin{array}{l}\text { Sandstone below } \\
\text { lignite in some } \\
\text { places. }\end{array}$ \\
\hline GROUP D. & & & & & . \\
\hline $\begin{array}{l}\text { Beaver Creek, } 10 \text { miles above } \\
\text { mouth. }\end{array}$ & $10-12$ & (e) & $\begin{array}{l}\text { Seams sepa- } \\
\text { rated by } \\
\text { clay and } \\
\text { sandstone. }\end{array}$ & 20 rods and $\frac{1}{2}$ mile. & $\begin{array}{l}\text { 10-foot seam re- } \\
\text { ported from this } \\
\text { vicinity. }\end{array}$ \\
\hline$\frac{1}{2}$ mile north of Read's ranch. & 3 & 0 & $\begin{array}{l}\text { Sandstone } \\
\text { above. }\end{array}$ & $\begin{array}{l}\text { Seen at several } \\
\text { points for a mile } \\
\text { or more. }\end{array}$ & $\begin{array}{l}\text { Two thin seams } \\
\text { above this may } \\
\text { represent the } \\
\text { seams at Read's. }\end{array}$ \\
\hline $\begin{array}{l}\text { Opposite Morgan's ranch, 6-7 } \\
\text { miles below Read's. }\end{array}$ & $6-8$ & $20-30$ & $\begin{array}{l}\text { Sandy clay } \\
\text { above: clay } \\
\text { containing } \\
\text { iron concre- } \\
\text { tions below. }\end{array}$ & 4 rods........ & $\begin{array}{l}\text { Two other seams } \\
\text { below this one, of } \\
2 \frac{1}{2} \text { and } 3 \text { feet, re- } \\
\text { spectively. }\end{array}$ \\
\hline $\begin{array}{l}\text { Just above the mouth of Bea- } \\
\text { ver Creek. }\end{array}$ & $3-4$ & $30-40$ & Sandy clays.. & 1 mile............. & $\begin{array}{l}\text { These seams were } \\
\text { followed } 6 \text { miles } \\
\text { down the river. }\end{array}$ \\
\hline $\begin{array}{l}\text { GROUP E. } \\
1.4 \text { miles north of Beaver } \\
\text { Creek, near Bolan Creek. }\end{array}$ & $\begin{array}{r}3 \\
4 \\
5 \\
10\end{array}$ & $80-90$ & $\left\{\begin{array}{l}\text { Clays, sandy } \\
\text { clays. }\end{array}\right.$ & $\begin{array}{l}\text { Several rods in } \\
\text { each case. }\end{array}$ & $\left\{\begin{array}{l}\text { The lower seam be- } \\
\text { longs to Group E. } \\
\text { The upper three } \\
\text { probably belong } \\
\text { to Group D. }\end{array}\right.$ \\
\hline
\end{tabular}

$a$ Wood, L. H., Third Bienn. Rept. Geol. Survey North Dakota, pp. 103-108.

$b$ Four seams; lowest at water level.

$c$ In bluff.

d In draw.

e Four seams above water level. 
Lignite seams along the valley of Little Missouri River between Medora and. Missouri River-Continued.

\begin{tabular}{|c|c|c|c|c|c|}
\hline Location of onterop. & $\begin{array}{l}\text { Thick- } \\
\text { ness of } \\
\text { seam. }\end{array}$ & $\begin{array}{c}\text { Eleva- } \\
\text { tion of } \\
\text { out- } \\
\text { crop } \\
\text { above } \\
\text { river. }\end{array}$ & $\begin{array}{l}\text { Materials } \\
\text { above and be- } \\
\text { low lignite. }\end{array}$ & Extent of outcrop. & Remarks. \\
\hline Group E-continued. & Feet. & Feet. & & . & \\
\hline $\begin{array}{l}\text { 6. - i miles below Bolan Creek, } \\
\text { on Red wing Creek. }\end{array}$ & ;0 & 100 & 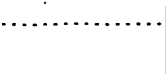 & Several rods..... & $\begin{array}{l}\text { Probably same as } \\
\text { the } 10 \text {-foot seam } \\
\text { at Bolan Creek. }\end{array}$ \\
\hline $\begin{array}{l}\text { 6-S miles below lRed wing, on } \\
\text { Squuw Creek. }\end{array}$ & 5 & $150-200$ & Sandy clay... & .....do. & $\begin{array}{l}\text { Seam runs on north } \\
\text { at high levels for } \\
10 \text { miles. }\end{array}$ \\
\hline GROUP F. & & & & & \\
\hline $\begin{array}{l}1 \text { '-12 miles north of Killdeer } \\
\text { Mountitins. }\end{array}$ & 11 & 0 & Clay ....... & 10 rods........ & . \\
\hline Near moquth of Jim Creck... & $6-8$ & 0 & ....do. & 5 rods.. & \\
\hline$\approx$ miles below Jim Creek..... & 8 & 0 & $\ldots$. do......... & 20 rods.......... & $\begin{array}{l}\text { A very handsome } \\
\text { outerop. }\end{array}$ \\
\hline $\begin{array}{l}\text { Manning's ranch, } 5 \text { miles be- } \\
\text { low Jim Creek. }\end{array}$ & $6-8$ & $20-30$ & $\begin{array}{l}\text { Very fine firm } \\
\text { clay. }\end{array}$ & & $\begin{array}{l}\text { This coal seam is } \\
\text { burning. }\end{array}$ \\
\hline $\begin{array}{l}3 \text { miles below Manning's } \\
\text { ranch. }\end{array}$ & 5 & 40 & Yellow clay.. & Several rods..... & $\begin{array}{l}\text { Seam probably ex- } \\
\text { tends several } \\
\text { miles farther. }\end{array}$ \\
\hline
\end{tabular}

Lignite on Big Box Elder Creek, Custer County, Mont.-Work along this creek was confined to the lower portion of its course. Near the confluence of Coal Bank and Big Box Elder creeks, about 1 mile above the South Dakota line, a seam of lignite 11 feet thick is exposed. The outcrop extends 200 feet along Coal Bank Creek, the lignite being covered by 8 to 1.0 feet of gravel and sand and lying 6 feet above the water. Six or seven miles above this point and not far from the Mill Iron ranch, a cut bank on Big Box Elḍer Creek shows the following section:

Section near Mill Iron ranch on Big Box Elder Creek.

Ft. in.

Gravel and silt...................................................

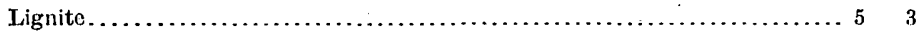

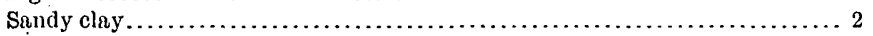

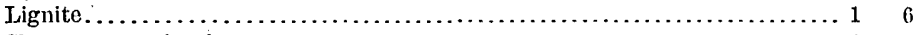

Clay, to water level. .............................................. 1

Mining is done in winter when the creek is frozen so that wagons can be driven on the ice, and the lignite is used by the neighboring ranches. In the higher buttes, which form part of the divide between Horse and Big Box Elder creeks, aboụt 4 miles north of the Mill Iron ranch, two seams of workable thickness occur. One lies near the base of the butte and is 6 to $7 \frac{1}{2}$ feet thick; the other is about 125 feet higher and has a thickness of 8 feet. In the vicinity of Ekalaka, 18 miles to the west, lignite is mined at a number of points and seams 4 to 9 feet thick are found.

One or two workable seams occur in the Long Pine Hills, just west of the Montana-South Dakota line, only a few miles from Camp Crook, S. Dak. Five miles northwest of town, on the land of Mr. Hoag, a small opening has been made in a 5-foot seam, separated from a lower seam 1 foot thick by 10 inches of clay. Not over three-fourths of a mile from this point, on Mr. Owen's place, a 6-foot seam of lignite has been mined for use in Camp Crook. The lignite lies well toward the base of the hills and appears to have considerable extent.

Lignite in South Dakota.-Lignite in South Dakota-is confined almost wholly. to Butte County, although a few thin seams are reported to occur on the Standing Rock Indian Reservation. On the Little Missouri, about 12 miles below Camp Crook, a 6-foot seam outcrops along the river and coal is obtained here by the ranchmen of the region. 
At a number of points in the Slim Buttes workable seams of lignite are exposed. At the north end two 5 -foot beds are present, the lower lying 110 feet above South Fo:k of Grand River and separated from the upper seam by 260 feet of sand and clay. On the west side, 5 or 6 miles from the north end of the butte, in sec. 12, T. 18 N., R. 7 E., a seam $10 \frac{3}{4}$ feet thick outcrops, and in sec. 23 of the same township and range two beds occur, one $4 \frac{1}{2}$ to 8 feet thick and the other $5 \frac{1}{2}$ to 6 feet.a A lignite bed 6 to 8 feet thick is reported to occur 8 miles east of Reva post-office and another 15 miles east.

Several good lignite seams are found on Big Nasty Creek, which has its source in the Cave Hills and flows southeastward into South Fork of Grand River. Two and one-inalf miles south of the Howard ranch coal is mined in sec. 2, T. 20 N., R. 8 E. The section here is as follows:

Section $2 \frac{1}{2}$ miles south of the Howard ranct.

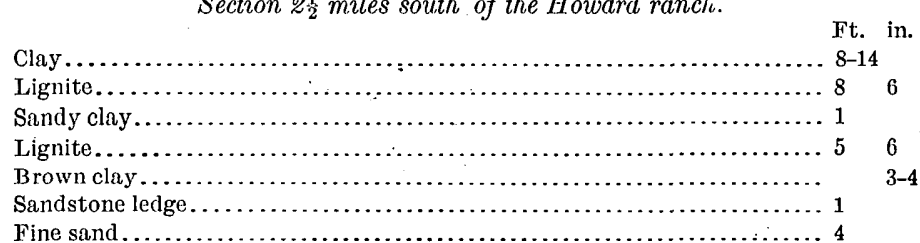

The lignite here exposed is of good quality. At the Bond place, 10 miles above the Howard ranch, a 7-foot seam occurs, separated by 9 inches of clay from a 3-foot seam. A lignite bed over 7 feet thick and of excellent quality is exposed on the Riley ranch, on the northeast side and near the base of the Cave Hills. The lignite lies only a few feet above the creek level and is overlain by 2 to 5 feet of clay. A bed 4 feet thick outcrops several miles north of Ludlow and at other localities in the Cave Hills.

Lignite is present at various points along North Fork of Grand River, which flows eastward near the boundary line between North and South Dakota. It outcrops 2 miles west of Haley, N. Dak., where a seam $6 \frac{1}{2}$ feet thick is exposed for 300 to 400 yards in a cut bank, the coal lying 4 to 6 feet above the river. Lignite is also mined 4 miles above this place, the bed being 5 to 6 feet thick. It is reported to occur at other localities on the North Fork, both above and below Haley. In the vicinity of Seim, near the junction of North and South forks of the Grand, lignite is plentiful. A 5-foot seam is exposed on Anderson's ranch, about 6 miles west of the reservation fence and several miles from Seim.

Lignite along Yellowstone River below Miles City.-In the vicinity of Glendive, Mont., a bed of lignite 6 feet thick occurs in the bluft's 1 mile northeast of town. The lignite is in two seams, each 3 feet thick and separated by 12 inches of clay. The Sims mine is opened in these seams and the product is of good quality. Much of the lignite used in Glendive comes from the Snyder mine, 8 miles north of town, being hauled in by teams. The seam is 8 feet thick and in the immediate vicinity there are three others of workable thickness, as follows:

\section{Lignite beds near Glendive, Mont.}

Feet.

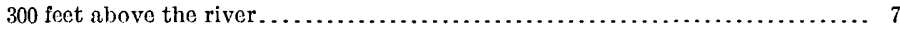

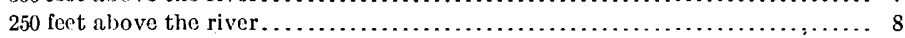

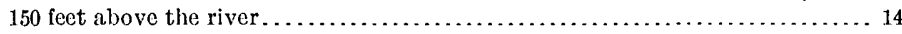

90 feet above the river........................................... 10

The lignite in the two upper beds is of excellent grade and considerable areas are underlain by it, as shown by the outcrops. On the west side of the Yellowsione, 12 miles above Glendive, at the Kinsey ranch, near the mouth of Clear Creek, a seam of lignite over $4 \frac{1}{2}$ feet thick has been mined where it outcrops in the hillside about 200 feet above the river.

Across the river from Fallon, about 3 miles northenst of the railroad station, a seam varying in thickness from $8 \frac{1}{2}$ to 10 feet is exposed at intervals for a distance of over 1 mile. At 
the west end of the outcrop the lignite contains several clay bands 3 to 8 inches thick, but farther east there is only one, near the top of the bed. Two miles above the Fallon ferry, at the mouth of Cottonwood Creek, a lower seam outcrops with a thickness of $6 \frac{1}{2}$ feet. $\Lambda \mathrm{t}$ this point the lignite lies 5 or 6 feet above the river; but one-half mile below, it is at water level. Near the mouth of O'Fallon Creek, on the land of Mr. Gifford, the following section is exposed in the river bank:

Section near mouth of O'Fallon Creek.

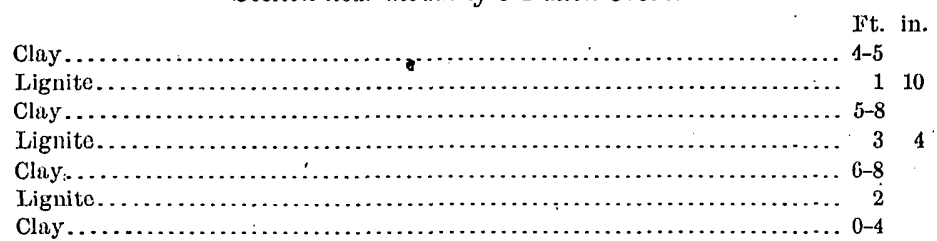

These seams probably underlie a large part of the extensive flat on which Fallon is located. About midway between Fallon and Terry, on the same side of the river', a seam of lignite 5 to $6 \frac{1}{2}$ feet thick occurs 12 feet above water level. In the river bluf's in the vicinity of the Blatchford station two seams of lignite are present. They are separated by 8 to 10 feet of clay, and are 5 to 6 and 6 to 7 feet thick, respectively. They are well exposed in the side valley extending back from Townsend ranch. At least one of these seams is found outcropping at intervals in the lateral ravines for a distance of 10 miles.

Lignite has been mined about Miles City for many years, the seams which have been worked varying from 18 inches to $4 \frac{1}{2}$ feet in thickness. The mines at present in operation are 5 miles from the city, the lignite being hauled by teams. The Kircher Brothers' mine, $l_{\text {ocated }} 5$ miles to the northeast, has been opened for seven years. The seam varies in thickness from 4 feet 2 inches to 4 feet 6 inches. The lignite is of excellent quality, black, lustrous, and brittle. At the Weaver mine, about the same distance from town, a 4-foot seim is being worked. Lignite is also mined on the west side of the Yellowstone, on Sunday Creek.

West of Miles City lignite is found along Cottonwood and Sarpy creeks, on the Crow Indian Reservation, near Forsyth, and at various points between Forsyth and Miles City.

On Beaver Creek, about 2 miles north of Wibaux, near the eastern boundary of Montana, a seam of lignite 11 to 12 feet thick outcrops at several points for a distance of a mile or so. It lies near creek level, and is overlain by 30 feet of soft sandstone and gravel. The seam doubtless has a considerable extent beneath the rolling plain east of the valley of Beaver Creek. Fifteen miles east of Wibaux, in North Dakota, a thick seam of coul occurs near the base of Sentinel Butte, 3 miles from the railroad station of the same name. The bed is over 21 feet thick and is mined for use in the town.

\section{DEVELOPMENT.}

Lignite is mined quite extensively at a number of localities, the larger mines being, of course, near the railroads. The lignite field is traversed east and west by the Great Northern and Northern Pacific railways; the Minneapolis, St. Paul and Sault Ste. Marie Railway, commonly known as the Soo, enters it near the northeastern border, and the Burlington and Missouri River. Railroad near the southern and western borders.

In North Dakota there are large mines, many of them well equipped, on the Soo road near Burlington and Kenmare, Ward County, and at Wilton, north of Bismarck, also at Lehigh, Sims, and New Salem, on the Northern Pacific Railway. In Montana the most important mines are located near Glendive and Miles City, and in Wyoming much lignite is mined near Sheridan. ? 
Besides the larger mines on or near the railroads there are hundreds of localities all over the area where lignite is mined on a larger or smaller scale. Throughout the greater portion of the area lignite is the only fuel used, and the ranchmen occasionally haul it 10 or 15 miles. Usually, however, there is a seam near by from which a supply may be obtained. It is generally taken from some outcrop where it can be gotten with the least amount of labor. When the seam lies near the surface the lignite is reached by stripping, or if it is exposed in a cut bank or steep bluft it is removed from the face of the outcrop with the pick or by blasting.

With few exceptions, the roof over the lignite is clay or sometimes soft sandstone, and timbering is necessary, at least in the entries. But where the seam is thick enough 6 inches to 2 feet of lignite is left, and this usually makes a safe roof, which may require no supports. 


\title{
- COAL AND OIL IN SOUTHERN UINTA COUNTTY, WYO.
}

\author{
By A. C. Veatch.
}

\section{INTRODUCTION.}

The following report is a brief preliminary statement of a portion of the results of surveys made by Alfred R. Schultz, Max A. Pishel, and the writer, during the summer of 1905, in Tps. 12 to 23 N., Rs. 115 to 121 W., inclusive, Uinta County, Wyo. Since the investigation was primarily an economic one, concerned principally with coal and oil; since coal lands can be acquired only in "legal subdivisions, as made by the regular United States [Land Office] survey," and since the petroleum "placer claims" in this region are always entered by legal subdivisions, it was considered imperative to do the work from a land-subdivision standpoint rather than as an abstract piece of geographic and geologic mapping. Such a method is necessary in all regions having the rectangular subdivisions of the General Land Office, to render the economic results immediately available both to the investor and to the Land Office.

Land lines were carefully followed, and geologic and sketch topographic maps prepared on a scale of 2 miles to the inch, with a contour interval of 100 feet. These separate field township sheets, covering an area slightly larger than the Wyoming portion of Pl. X, are now being compiled into a single map on a scale of 1 inch to the mile. This map will show all the land corners found in this examination, and enable anyone to determine at a glance the degree of aecuracy of any location under consideration. It will be used as a base for the several maps which will accompany the complete report now in preparation. These will show areal geology, structural geology, location of coal beds, and depth of principal beds throughout the area underlain by them; also depths to the oil-benring shales in the regions where they may be found. This detailed report will probably be ready for distribution in the spring of 1907, and the reader is referred to it for an elaboration and amplification of the points here outlined and of the sketch maps here presented.

\section{STRATIGRAPHY.}

The fossils collected by this party and studied by Stanton, Girty, and Knowlton, as well as the material collected by former expeditions, indicate that the several formations observed and mapped in the field have the geologic time values shown in the accompanying table. 
Succession and age of beds in southern U insa County, Wyo.

\begin{tabular}{|c|c|c|c|c|c|}
\hline Age. & Formation or group. & Character of strata. & Where exposed. & Thickness. & Economic value. \\
\hline Quaternary. & $\cdot$ & Terrace, flood plain, and hill-wash phenomena. & Throughout area. & Feet. & $\begin{array}{l}\text { Clayey deposits derived largely from the } \\
\text { weathering of underlying shale beds have } \\
\text { been used tor brick near Glencoe: }\end{array}$ \\
\hline \multicolumn{6}{|c|}{ Unconformity. } \\
\hline $\begin{array}{l}\text { Pliocene or Pleisto- } \\
\text { cene. }\end{array}$ & $\begin{array}{l}\text { Wyoming conglom- } \\
\text { erate. }\end{array}$ & $\begin{array}{l}\text { Multicolored pebbles in a light-gray sandstone ma- } \\
\text { trix. }\end{array}$ & $\begin{array}{l}\text { Not typically developed in this } \\
\text { area. Suggested by gravels } \\
\text { capping high hills northeast of } \\
\text { Hilliard. }\end{array}$ & $0-50$ & . \\
\hline \multicolumn{6}{|c|}{ Unconformity. } \\
\hline \multirow{6}{*}{ Eocene. } & Bridger. & $\begin{array}{l}\text { Greenish sainds and clays, with occasional white } \\
\text { bands. Contains a large mammalian fauna. }\end{array}$ & $\begin{array}{l}\text { Portion of area southeast of } \\
\text { Union Pacific Railroad. }\end{array}$ & $a 1,800$ & \\
\hline & Green River. & $\begin{array}{l}\text { Light-colored, thin-bedded shales, with abundant } \\
\text { tsh remains. }\end{array}$ & $\begin{array}{l}\text { Between Hams Fork and Rock } \\
\text { Creek; about headwaters of } \\
\text { Twin Creak; east of Meridian } \\
\text { anticline. }\end{array}$ & $b 2,000$. & . \\
\hline & \multirow{4}{*}{ Wasatch, } & $\begin{array}{l}\text { Variegated yellow and red sandy clays, with irregu. } \\
\text { larly bedded white and yellow sandstones. Con- } \\
\text { tain some mammals. }\end{array}$ & Throughout area. & $+1,500$ & $\begin{array}{l}\text { Yields oil and flowing sulphur water at } \\
\text { Fossil; but oil has clearly leaked } \\
\text { through fault from underlying Creta- } \\
\text { ceous beds. Yields towing water of } \\
\text { good quality on Bear River above Ev. } \\
\text { anston. }\end{array}$ \\
\hline & & \multicolumn{4}{|l|}{ Unconformity. } \\
\hline & & $\begin{array}{l}\text { "White beds," composed largely of volcanic ash, } \\
\text { but containing thin limestone layers with fresh- } \\
\text { water shells. }\end{array}$ & $\begin{array}{l}\text { Yellow Creek, Bear River, Dry } \\
\text { Hollow, and Bridger Creek. }\end{array}$ & $+2,500$ & . \\
\hline & & $\begin{array}{l}\text { Conglomerates, sandstones, and reddish-yellow } \\
\text { sandy clays. Typically exposed east of. Almy. }\end{array}$ & $\begin{array}{l}\text { Throughout area near contact of } \\
\text { Wasatch and older rocks. }\end{array}$ & 2,100 & $c_{1}$ \\
\hline & Evanston. $c$ & $\begin{array}{l}\text { Gray and yellow clays, with irregular sandstone } \\
\text { beds containing Almy coal and several minor coal } \\
\text { beds. Characterized by plants which are distinc- } \\
\text { tive of the 'upper Laramie beds, and by inverte- } \\
\text { brates whieh are common to the Laramie and Fort } \\
\text { Union. Rests on Bear River and Jurassic beds. }\end{array}$ & From Evanston, 10 miles north. & 1.500 & $\begin{array}{l}\text { Contains coal mined at the Evanston (A } A^{\text {my }} \\
\text { and Red Canyon) mines. The main coal } \\
\text { seam has been reported as much as } 33 \text { feet } \\
\text { thick. but it contains much bone, and for } \\
\text { present purposes may be regarded as hav- } \\
\text { ing a thickness of } 18 \text { feet, workable in two } \\
\text { benches. }\end{array}$ \\
\hline
\end{tabular}

a Measured by W. D. Matthew and Walter Granger.

$c$ E. A White in Eleventh Ann. Rept. U. S. Geol. and Geog. Surv. Territories, 1879, pp. 240-241, used the name "Evanston coal series" in referring to the coal-bearing beds at Almy below the Wasatch and above the Bear River. Lesquereux (Sixth Ann. Rept. Geol. Surv. Territories, 1873, p. 409) has used the name "Evanston deposits." 
Succession and age of beds in southern Uinta County, Wyo.-Continued.

\begin{tabular}{|c|c|c|c|c|c|}
\hline Age. & Formation or group. & Character of strata. & Where exposed. & Thickness. & Economic value. \\
\hline \multirow[b]{4}{*}{ Cretaceous. } & & Unconformity. & & & \\
\hline & Laramie. & 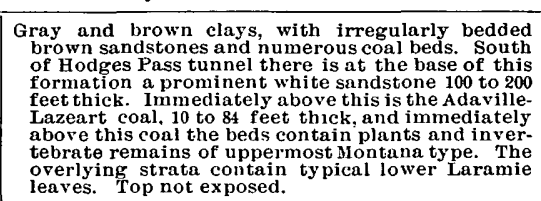 & $\begin{array}{l}\text { Along west side of Dammoth Hol- } \\
\text { low from Lazeart mine to Clear } \\
\text { Creek and from Little IJuddy to } \\
\text { Hams Fork. }\end{array}$ & $\begin{array}{l}\text { Feet. } \\
+5,000\end{array}$ & 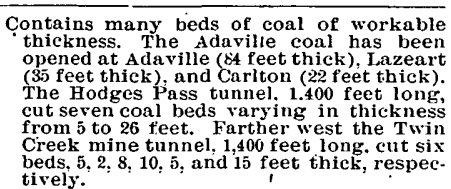 \\
\hline & Montana. & \multirow{2}{*}{ 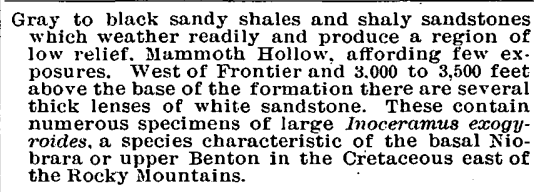 } & \multirow{2}{*}{$\begin{array}{l}\text { Along Hammoth Hollow and near } \\
\text { Hilliard. }\end{array}$} & \multirow[t]{2}{*}{6,500} & \multirow{2}{*}{ 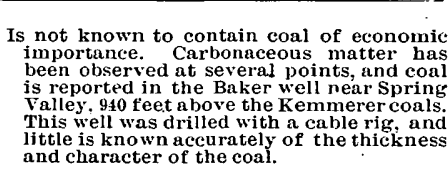 } \\
\hline & \multirow{3}{*}{ Colorado. } & & & & \\
\hline \multirow[b]{4}{*}{.. } & & 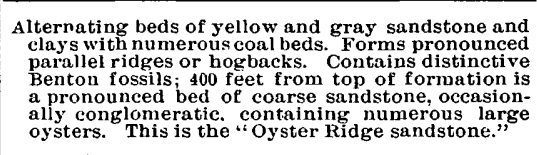 & 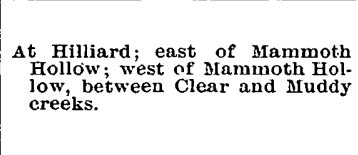 & 2,400 & 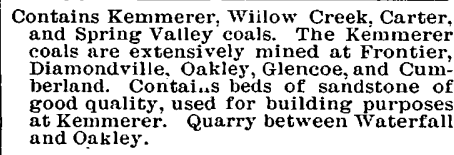 \\
\hline & & $\begin{array}{l}\text { Black and gray shales containing abundant flsh } \\
\text { scales; commonly weathering silvery gray. }\end{array}$ & $\begin{array}{l}\text { Between Oyster Ridge and Merid- } \\
\text { ian anticline; near Mlillis and } \\
\text { Knight. }\end{array}$ & 1,800 & $\begin{array}{l}\text { Contains oil developed in wells northeast of } \\
\text { Spring Valley. Probable source of oil in } \\
\text { Hilliard, Carter, and Fossil oil springs. }\end{array}$ \\
\hline & Bear River. & $\begin{array}{l}\text { Black shales and shaly sandstones containing abun- } \\
\text { dant invertebrate fossils and several thin beds of } \\
\text { impure coal. }\end{array}$ & $\begin{array}{l}\text { East of Oyster Ridge, near Hil- } \\
\text { liard, ats many points between } \\
\text { Evanston and Beckwith. }\end{array}$ & $a+2,400$ & $\begin{array}{l}\text { Attempts have been made to develop coal } \\
\text { bedsin this formation at Sage and Coke- } \\
\text { ville. Beds too thin and impure to be of } \\
\text { value. Bueds }\end{array}$ \\
\hline & & $\begin{array}{l}\text { Red, yellow, and reddish-yellow shales and sand- } \\
\text { stones, often containing thick reddish conglomer- } \\
\text { ate beds. }\end{array}$ & $\begin{array}{l}\text { Along Meridian anticline; west of } \\
\text { Absaroka fault; west of kock } \\
\text { Creek anticline. }\end{array}$ & $b 5,500$ & 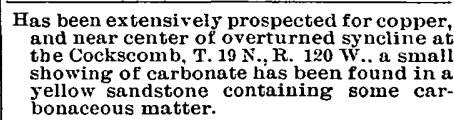 \\
\hline
\end{tabular}

a This is the thickness found on the west side of this area. On the east side, along the Meridian anticline, the formation is often only 100 feet thick.
$b$ Thickness west of Rock Creek. To the south the beds thin rapidly and the total thickness of the Jurassic in the Uinta 1 ountains is probably less than 1,000 feet. 


\begin{tabular}{|c|c|c|c|c|c|}
\hline Age. & Formation or group. & Character of strata. & Where exposed. & Thickness. & Economic value. \\
\hline Jurassic. & & $\begin{array}{l}\text { Black and gray shales and shaly limestones, with } \\
\text { occasional beds of yellow sandstone the whole } \\
\text { containing numerous characteristic marine } \\
\text { upper Jurassic fossils. }\end{array}$ & Rock and Twin creeks. & $\begin{array}{l}\text { Feet. } \\
\quad a 3,600\end{array}$ & $\begin{array}{l}\text { The oil in the Pittsburg-Salt Lake Com- } \\
\text { pany's well in sec. 10, T. 14 N.. R. 118 W., } \\
\text { seems to come from this horizon. }\end{array}$ \\
\hline & . & $\begin{array}{l}\text { Yellow, thin-bedded sandstones, weathering dark } \\
\text { brown. }\end{array}$ & Rock and Twin creeks. & 1,300 & \\
\hline Triassic! & & Red sandstones and shales. & $\begin{array}{l}\text { Rock and Twin creeks; best ex- } \\
\text { posed about Nugget Station. }\end{array}$ & 600 & \\
\hline \multirow{3}{*}{ "Permo-"Carbonif- } & & $\begin{array}{l}\text { Gray cherty limestones and yellow sandstones con- } \\
\text { taining an ibuundant and characteristic "Permo- } \\
\text { Carboniferous" fauna. }\end{array}$ & $\begin{array}{l}\text { Rock Creek, } \\
\text { west of Cumberland. }\end{array}$ & 2,500 & \\
\hline & & Red shales and sandstones. & Rock Creel. & 750 & . \\
\hline & & $\begin{array}{l}\text { Gray to white sandstones, sometimes calcareous and } \\
\text { often brecciated. Base not seen. }\end{array}$ & Rock Creek. & $+1,000$ & $\begin{array}{l}\text { Has been prospected for copper, and just } \\
\text { north of watercress Canyon, T. } 22 \text { N.. } R \text {. } \\
118 W_{\text {.; }} \text { a showing of carbonates has been } \\
\text { found. }\end{array}$ \\
\hline $\begin{array}{l}\text { Pennsylvanian (Up- } \\
\text { per Carboniferous). }\end{array}$ & & $\begin{array}{l}\text { Hard black and blue-gray cherty limestones con- } \\
\text { taining Upper Carboniferous fossils. At no place } \\
\text { were these rocks seen in contact with the sand- } \\
\text { stone mentioned above. }\end{array}$ & $\begin{array}{l}\text { Along Bear River from the Nar- } \\
\text { rows intermittently to Coke- } \\
\text { ville. }\end{array}$ & $\begin{array}{l}\text { Not } \\
\text { determined. }\end{array}$ & \\
\hline
\end{tabular}

$a$ Thickness west of Rock Creek. To the south the beds thin rapidly and the total thickness of the Jurassic in the Uinta Mountains is probably less than 1,000 feet. 


\section{STRUCTURE.}

The disturbances of the strata in this area are traceable to two periods-late Cretaceous and early Tertiary.

(1) Near the close of the Cretaceous period, between the Laramie and Evanston, the main folding of this region took place, producing the Meridian anticline, Lazeart syncline, Absaroka fault, Rock Creek anticline, and associated structural features. (2) On the eroded edges of these upturned beds the Evanston beds were laid down, and some time after the deposition of the lower Wasatch conglomerates, movements along several of the old lines of deformation tilted and faulted these younger beds, producing in some cases very high local dips, often in directions opposite to those of the older beds. These phenomena are of considerable importance in indicating the directions of thrust. The more important of these disturbances of the Eocene beds are traceable to movements along the Absaroka fault, the Rock Creek-Needles anticlinal, and a secondary fault line along Bear River, north of Evanston.

The important structural features in the pre-Evanston beds in this area are from eust to west (see Pls. X and XI): (1) A rather regular anticline-the Merdian anticline; (2) a somewhat disturbed, and in places overturned, syncline-the Lazeart syncline; (3) a much broken region lying between this syncline and the fault to the west; (4) a large and very persistent faulted anticline, with a downthrow to the east-the Absaroka fuult; (5) a somewhat disturbed synclinal basin, deeply filled with Tertiary material, lying between the Absaroka fault and the uplifted and disturbed region toward the west; (6) a greatly disturbed region, which in its broader features, consists of a somewhat broken anticline of "Permo-Carboniferous", and Jurassic beds, whose westward flank is broken by a number of minor irregular folds and faults; and (7) a folded and faulted mass of Upper Carboniferous rocks-the Crawford Mountains.

The Meridian anticline is almost wholly buried by 'Tertiary beds, which, as they dip eastward across the whole ant:cline, give no clew to its position. The crest of this anticline is exposed in the valley of Little Muddy Creek, 3 or 4 miles east of Cumberland and east of Front:er, where it shows dips to the east of about the same amount as those to the west. The inferred positions of the coal beds and o:l-bearing shale on its east s:de (PIs. X and XI) are based wholly on the assumption that th:s is a s:mple anticline. To the north it shows some tendency toward complexity, with one or more secondary folds to the east, and this complexity may extend farther to the south.

Near Hilliard the Lazeart syncline is entirely overturned, the lower limb dipping westward at angles of from $25^{\circ}$ to $30^{\circ}$, and the upper limb at from $90^{\circ}$ to $130^{\circ}$. Between Hilliard and the Aspen tunnel it returns to a normal syncline, with dips of $20^{\circ}$ to $30^{\circ}$ on the east and $40^{\circ}$ to $75^{\circ}$ on the west. At Round Mountain it is again overturned and perhaps faulted, but from that point northward it appears entirely normal, with dips on the west side commonly more than double those on the east. The Laram:e beds which occur along the deepest parts of this syncline are broken by the rising and pitching of the syncline into three basins-at Hilliard, between Lazeart and Round Mountain, and between Little Muddy Creek and a point 2 miles north of Hams Fork.

Between the Lazeart syncline and the Absaroka fault the beds are greatly disturbed, the amount of d:sturbance increasing with proximity to the fault line.

In the Absaroka fault the displacement is something over 15,000 feet, with the downthrow to the east. In the Absaroka Ridge region there is some folding west of the fault line, but beyond this the beds dip westward, indicating that the area between the fault and the overturned Rock Creek anticline is a broad syncline. On Sulphur Creek and about Knight the Jurassic beds just west of the fault suggest a closely compacted anticline, merging toward the west into an overturned syncline (Pl. XII, $A$ ). The eastward-dipping Bear River beds and the coals near Old Millis siding (on Sulphur Creek, due south of Knight) are clearly on the upper of eastward flank of an overturned syncline. 
Of the disturbed region along the west of the Rock Creek-Needles anticlinal, little need be suid in this paper, s.nce, with the exception of the beds of Evanston age, containing the Almy coals, the formations here are all Bear River or older, and hence le below the main coal measures of this reg.on. The formations are also older than the beds yelding oil at Spring Valley, and are, moreover, too badly broken to be of probable importance from an oil standpoint. The Almy coals are found on the east side of a minor faulted anticline on the west side of the Rock Creek-Needles anticlinal.

\section{COAL.}

Coal developments have been made in four different groups of coal-bearing beds(1) the Bear River formation; (2) a group containing the Kemmerer, Willow Creek, Carter, and Spring Valley coals, of Benton age; (3) a group containing the Adaville and Twin Creek coals, of uppermost Montana and Laram:e age; and (4) the beds of upper Laramie or Evanston age at Almy.

Coal of the Bear River formation.-Peale $a$ reports that coal was discovered near Suge in 1875, and that before his visit in 1877 a mine had been opened by the Wyoming Coal and Coking Company and coke ovens erected. 'The slope was 470 feet in length, with a single side entry 120 feet long. He reports the following section:

\section{Section of coal-bearing strata at Sage, Uinta County, Wyo.}

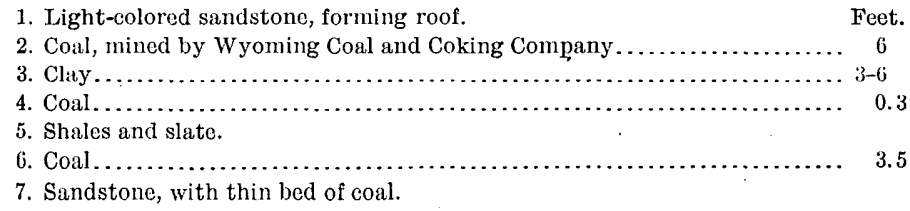

It is reported that picked samples of this coal will make coke and that washing was tried to remove the impurities. With the building of the Oregon Short Line in 1881 a second attempt was made to develop this locality, and a third trial was made in 1890 , when, it is reported, the old slope was deepened about 200 feet and several new entries were driven. A new coke oven was constructed' under the direction of a Pennsylvania expert, who, after careful tests, pronounced the coal of no value as a coking coal. Altogether about $\$ 130,000$ has been spent in a fruitless attempt to develop the coal at th:s point.

This mine is st.ll open, although the lower part is filled with water. An examination of the coal bed near the mouth of the mine showed $5 \frac{1}{2}$ feet of very impure coal.

Stanton has shown that the upper coal here is above beds containing marine lower Colorado foss.ls, while the beds adjo:ning the lower coals contain typical Bear River species.b Similar coals are found in the Bear River formation at Cokeville (formerly called Coketown), 20 miles north of Sage, and attempts to develop these beds have likewise proved fruitless. Prospects have been opened just east of Beckwith in the same beds which occur at Sage.

Coal-bearing beds containing the Kemmerer, Willow Creek, Carter, and Spring Valley coals.The coals in this group were first discovered by Frémont near the present site of Cumberland, August 19, 1843.c In 1848 Clayton $d$ reported coal in these beds on Sulphur Creek near the site of old Bear River City, and in 1852 Stansbury described the locality and placed on the map accompanying his report the words "Great Coal Basin," extending from the

a Peale, A. C., Report on the geology of the Green River district: Eleventh Ann. Rept. U. S. Geol. and Geog. Surv. Terr. (for 1877), 1879, pp. 574-575.

$b$ Am. Jour. Sci., 3d ser., vol. 43,1892 , p. 108.

c Frémont, J.C., Report of the Exploring Expedition to Rocky Mountains and to Oregon and North California, 28th Cong., 2d sess., House Doc. No. 166, 1845, pp. 131, 297.

d Clayton, W., Latter Day Saints Emigrants' Guide, 1848, p. 29. 


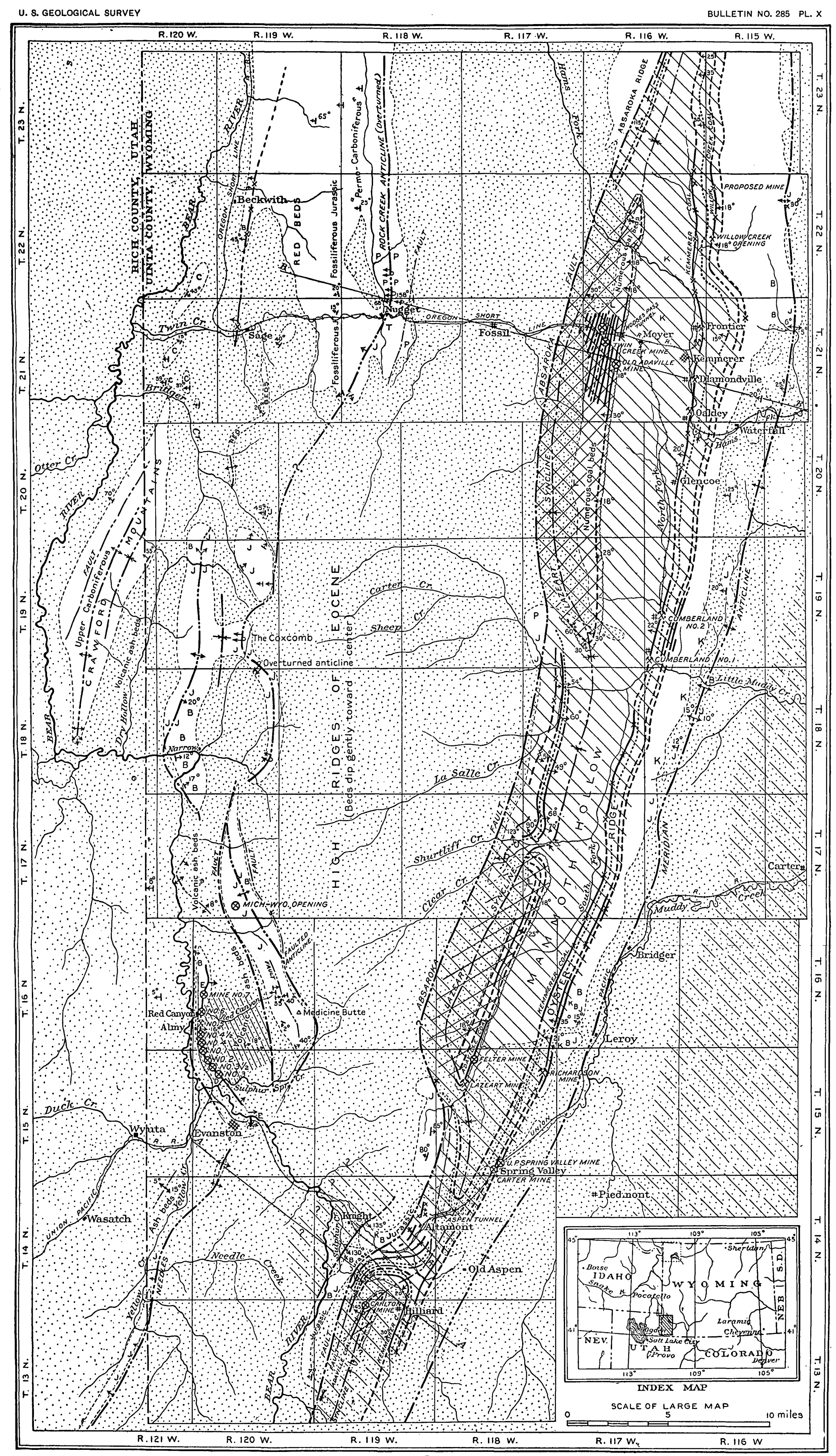

LEGEND

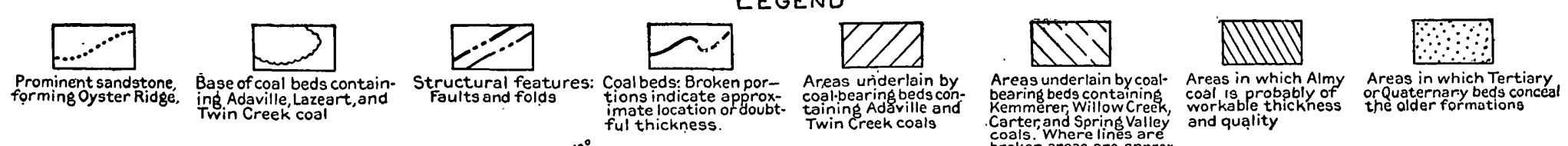

$\otimes$ Mines abandoned $x$ Prospects $10^{\circ}$ Normal dip

E. Evanston L. Laramie K. Cretaceous B. Bear River J.Jurassic P. "Permo-Cärboniferous" C. Upper Carboniferous

MAP OF COAL FIELDS OF SOUTHERN UINTA COUNTY, WYO.

By A. C. Veatch and A. R. Schultz. 
west bank of Bear River, near the present city of Evanston to Point of Rocks, Sweetwater County. ${ }^{a}$ The beds at th:s point were opened about the time of the bullding of the Union Pacific Railroad in 1869 , but were never worked to any great extent.

In 1859 a United States m.litary coal reservation was established at a point about 3 miles east, in beds of the same age, but this coal also was but little worked, although it is probable that small amounts were hauled to Fort Bridger for blacksmithing purposes.

The first important mine in these beds was that of the Diamond Coal and Coke Company at Diamondv'lle, opened in 1894. Subsequently mincs were opened by the same company at Glencee and Oakley. The Kemmerer mines were opened in 1897, by the Kemmerer Coal Company, and the Cumberland mines by the Union Pacific Coal Company in 1900 , the year in which this company finally abandoned its Almy mines. All these mines develop the main Kemmerer bed, which varies in thickness in the workings from 5 to 20 fect. $\Lambda t$ some points between these mines, along the outcrop, the bed is very thin or even absent. At Diamondville $\Omega$ coal about 5 feet thick and about 50 feet above the main bed is worked to a small extent, and at Kemmerer a bed $6 \frac{1}{2}$ feet thick has been opened 15 feet below the main bed.

The Willow Creek coal is about 550 feet below the main Kemmerer coal. It is thin or absent in the south end of the field, but reaches a thickness of 5 feet 8 inches in T. $22 \mathrm{~N}$., R. 115 W., where the Kemmerer Coal Company proposes to open a mine. Tests of this coal have yielded a coke of fair quality, and it is for its coking value that this coal is to be developed.

The Spring Valley coal is 1,475 feet stratigraphically below the Kemmerer coal. A mine was opened in this bed at Spring Valley by the Union Pacific Coal Company in 1899, but the mine was abandoned in 1905. The bed here is from 5 to 6 feet thick, with several irregular partings. The coal is rather dirty, and the mine was finally abandoned because of the bad roof and gas. The Carter coal seam is 1.75 feet above the Spring Valley bed, and is 7 feet 9 inches thick, with two partings having a total thickness of 1 foot 7 inches. It has been worked to a limited extent in the Carter opening at Spring Valley. A small mine northeast of Hilliard develops one of th's group of beds and supplies a limited amount of coal for local use. Openings have also been made in sec. 12 , T. 15 N., R. 118 W., to supply fuel for drilling neighbor.ng oil wells.

The approximate outcrop and the area underlain by these coals is shown in Pl. X. They outcrop along the west flank of the Meridian ant.cline throughout the area and on the west flank of the Lazeart syncline in the region of Altamont, between Clear Creek and a point 2 miles north of Little Muddy and north of Hams Fork. On the east side of the syncline the dip is from $8^{\circ}$ to $35^{\circ}$ and on the west it is generally over $45^{\circ}$. Near the $A$ bsaroka fault the beds, while coal bearing, are so badly broken that they are of little commercial importance. This is notably the case at Altamont. The amount of conl in sight in this basin is very large, and although the beds are somewhat irregular mining will be carried on here for many years.

Coal-bearing beds containing the Adaville and Twin Creek coals.-From an enrly day this coal-bearing group has been noted for the great number and thickness of its coal seams. Peale reports that the Smith and Bell Brothers in 1876 discovered and opened in the region of Hodges Pass on the divide between Twin Creek and Hams Fork twenty-nine beds of coal, ranging in thickness from $1 \frac{1}{2}$ to 48 feet and aggregating 315 feet. $b$

On the completion of the Oregon Short Line the Union Pacific Coal Company opened mines a mile west of Hodges Pass tunnel. Mine No. 1 was opened in 1881 and No. 2 in 1882.

a Stansbury, Capt. Howard, Fxploration and Survey of the Great Salt Lake of Utah, 1852, pp. 226, 280. b Peale, A. C., Jeport on the geology of the Green River district: Eleventh $A$ nn. Tept. U. S. Geol. and Geog. Surv. Terr. (for 1877), 1879, p. 535. Peale states that the twenty-nine beds oceurred in a thickness of three hundred and fifteen feet, which is incorrect; but a statement that the aggregate thickness is three hundred and fifteen feet is quite within the facts now known, and was probably the actual statement made by his informant. 
In mine No. 1 a horizontal prospect tunnel 1,400 feet long cut beds $5,8,10,5$, and 1.5 feet in thickness, while in mine No. 2 two beds, stratigraphically 750 feet above the uppermost bed in No. 1, were opened 120 feet apart, one 20 and the other 14 feet thick. These mines were abandoned in 1885. The Hodges Pass tunnel, 1,400 feet long, cut coal beds $9 \frac{1}{2} 38,6,14,6$, 5 , and 6 feet thick. Three miles south of this tunnel the prospect tunnel at the Adaville opening cut a bed 84 feet thick, with a single parting of clay 2 inches thick. Th.s mine was abandoned after one shipment of coal because the coal slacked badly, but the fact that the roof of the opening, composed entirely of coal and not timbered, is solid and of good luster after fifteen years' exposure to the air suggests that the coal may perhaps have shipping qualities. The coal exposed in this mine is on the whole a much cleaner coal than that found in the Kemmerer seam.

This lower or big vein has been opened further south, at the Lazeart mine, west of Spring Valley, and the Carlton mine, near Hilliard. The Lazeart mine was in operation in the summer of 1905, and its small product was hauled by wagons to Evanston or sold to local o.l operators. At both these mines it was stated that the product crumbled badly.

Because of the rising and pitching character of the Lazeart syncline the beds of this group occupy three basins, the first extending from 2 miles north of Hams Fork to 2 miles north of Little Muddy Creek, the second from Clear Creek to the Lazeart coal mine, and the third from near Sulphur Creek southward for an undetermined distance, probably but a few miles.

This coal-bearing group contains an immense amount of fuel of fair quality, that will undoubtedly be largely developed in the future.

Almy coals.-With the completion of the Union Pacific Railroad in 1869, mines were at once opened in the coal-bear:ing beds at Almy, a few miles north of Evanston. The Wyoming Coal Company (later the Union Pacific Coal Company) shipped coal in 1869 and the Rocky Mountain Coal and Iron Company in 1870. The latter supplied for a number of years the coal used over a large part of the Central Pacific Railroad. Peale reports that the coal-bearing beds vary in thickness from 22 to 32 feet, $a$ but these thicknesses include large proportions of bone. The workable coal is to be regarded as from 15 to 20 feet thick, and is worked in two benches. The Union Pacific Coal Company continued operations at this point until 1900, when the mines were abandoned because of fires and a change in dip in the lower part of the mines, which rendered it difficult to continue operations in the way they had been started. The Rocky Mountain Coal and Iron Company is st:ll operating mine No. 5 on a small scale. The output is hauled from the mine by wagon and the consumption is entirely local.

The developments here have shown that the coal is of commercial thickness and quality only for about 4 miles along the outcrop. The dip is from $15^{\circ}$ to $20^{\circ}$, but decreases rap.dly to the east, and the trough of a small syncline is reached at a distance of a quarter of a m.le from the outcrop. The surface dips indicate that this is a minor feature and that beyond a slight rise the eastward dip will continue. There is st:ll a considerable amount of unworked coal in this area, the most of which is now controlled by the Rocky Mountain Coal and Iron Company. 


\section{QUALITY OF COAL.}

Ten samples of coal were collected from mines in this region. The samples were taken with great care, pulverized and quartered in the mines, and sent in sealed cans to the chemical laboratory $a$ of the United States Geological Survey coal-testing plant, St. Louis, Mo., where the following analyses were made:

\section{Analyses of cocils from southern Uinta County, Wyo.}

[F. M. Stanton, analyst.]

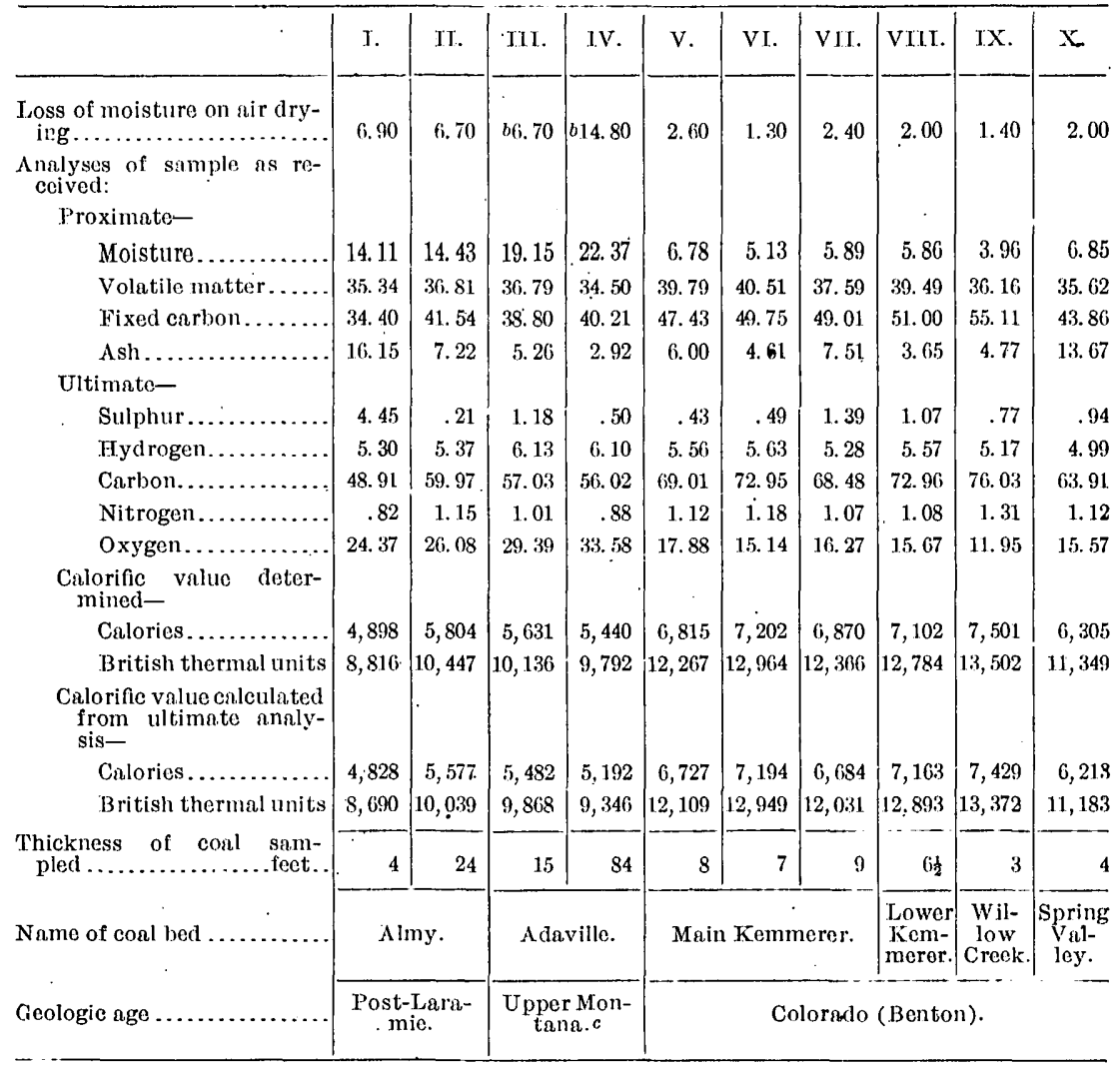

a Chemical laboratory in charge of Prof. N. W. Lord, of the Ohio State University.

b) The air-drying losses in the $A$ duville and Lazent coals do not appear to be entirely comparable.

$c$ This is just below the Laramie coals and may be said to represent them.

T. Michigan-Wyoming Oil Company's mine, NW. $\frac{1}{1}$ sec. 35 , 'T. 17 N., R. 120 W. Sample taken 40 feet from mouth of mine. Bone 1 inch thick 6 inches from the roof and 4 inches thick 18 inches from the roof, omitted in sampling. Sample represents total thickness of bed.

IT. Rocky Mountain Coal and Iron Company's mine No. 5, Almy, Wyo. Sample taken 3,000 feet from mouth of slope in room 5 , entry 12 , and represents lower 8 feet of 24 -foot vein. Upper part of bed contains numerous partings.

III. Lazeart mine, SE. + SW. 1 sec. 8 , T. 15 N., R. 118 W. Sample taken 15 feet from mouth of slope. Bed is 30 feet thick and sample represents upper 13 feet.

IV. Adaville mine, NE. $\frac{1}{\mathrm{SW}} \cdot \frac{1}{4} \mathrm{sec} .20, \mathrm{~T} .21 \mathrm{~N}$., R. $116 \mathrm{~W}$. This sample is from a tunnel driven horizontally across the coal bed, which is here 84 feet thick and dips $18^{\circ} \mathrm{W}$. 'Tunnel is 6 feet high and sample was collected by means of vertical cuts every 50 feet. This sample represents slightly hess than half the thickness of the bed. There are no partings and the conl is remarkably uniform throughout.

V. Union Pacific Conl Company, Cumberland No. 1 mine, Cumberland, Wyo. Sample from the face of seventh entry south, 2,100 feet west and 2,000 fcet south of mouth of mine. Sample represents entire hed.

VI. Diamondville Coal and Coke Company, Diamondville No. 1 mine.. Sample from room No. 45, entry No. 1 north, 160 feet west and 3,200 fcet north of mouth of mine. A clay seam 4 inches thick 1 foot from roof was omitted in sampling. Coal at the roint sampled is regarded as best in the mine. 
VII. Kemmerer Coal Company, Kemmerer No. 1 minc, Frontier, Wyo. Sample taken from room 46 , cntry 3 south, 600 fcet west and 2,250 feet south of mouth of mine. Sample represents a complete section of coal. No definite partings.

VIII. Kemmerer Coal Company, Kemmerer: No. 1 mine, Frontier, Wyo. Sample from working face in new opening in lower bed. From mouth of mine 600 feet south, 250 feet east (this portion is a crosscut from the main seam to the lower bed), and 250 feet south of working face. Bed is $6 \frac{1}{2}$ feet thick and 40 feet below main bed. Band of dirt 6 inches thick 4 feet from floor omitted in sampling.

IX. Kemmerer Coal Company, Willow Creek opening, SW. $\frac{1}{4}$ NW. $\frac{1}{4}$ sec. 19, T. 22 N., R. 115 W. Sample from face of entry 150 feet from mouth of mine. Bed 3 feet thick, with no partings. Regarded by owners as a coking coal.

X. Richardson mine, NW. $\frac{1}{4}$ sec. 12, T. 15 N., R. 118 W. Sample taken 150 feet west and 50 feet north of mouth of mine. Clay seam 3 inches thick and 1 foot from floor omitted in sampling.

In order that these analyses may be compared with others which have already been made in this region, the following table has been prepared, with the analyses separated into groups according to the geological horizons of the coals. The ash and sulphurwhich, while accidental impurities varying greatly from point to point in the same bed, are still of great commercial importance-have been calculated on the basis of air-dried samples. The moisture, volatile combustible matter, and fixed carbon have been recalculated on the basis of the air-dried ash-free samples.

Proximate analyses of coals from southern Uinta County, Wyo.

COALS OF BENTON (CRETACEOUS) AGE, INCLUDiNG THE KEMMERER, WILLOW CREEK CARTER, AND SPRING VALLEY BEDS.

\begin{tabular}{|c|c|c|c|c|c|c|c|c|}
\hline \multirow[b]{2}{*}{ Source of sample. } & \multirow[b]{2}{*}{ Ash. } & \multirow[b]{2}{*}{$\begin{array}{l}\text { Sul- } \\
\text { phur. }\end{array}$} & \multirow[b]{2}{*}{$\begin{array}{l}\text { Mois- } \\
\text { ture } \\
\text { in air- } \\
\text { dried } \\
\text { ash- } \\
\text { free } \\
\text { sam- } \\
\text { ple. }\end{array}$} & \multirow[b]{2}{*}{$\begin{array}{c}\text { Vola- } \\
\text { tile } \\
\text { com- } \\
\text { busti- } \\
\text { bles. }\end{array}$} & \multirow[b]{2}{*}{$\begin{array}{c}\text { Fixed } \\
\text { car- } \\
\text { bon. }\end{array}$} & \multicolumn{2}{|c|}{$\begin{array}{l}\text { Calorific: } \\
\text { values. }\end{array}$} & \multirow[b]{2}{*}{ Analyst. } \\
\hline & & & & & & $\begin{array}{c}\text { As } \\
\text { deter- } \\
\text { mined. }\end{array}$ & $\begin{array}{c}\text { Cal- } \\
\text { culat- } \\
\text { ed for } \\
\text { air- } \\
\text { dried } \\
\text { ash- } \\
\text { free } \\
\text { sam- } \\
\text { ple. }\end{array}$ & \\
\hline $\begin{array}{l}\text { J. D. Curtis, Hams Tork, } \\
\text { prospect sample. }\end{array}$ & 2.85 & 1.00 & 1.54 & 39.01 & 59.45 & 7,560 & 7,782 & Slosson fund Knight. $a$ \\
\hline $\begin{array}{l}\text { William Goodell, Hams } \\
\text { Fork, 6-foot face sample. }\end{array}$ & 4.05 & $\ldots \ldots$ & 3.07 . & 39.65 & 56.28 & 7,467 & 7,782 & Do. \\
\hline $\begin{array}{l}\text { A. Kendall, Fams Fork, } \\
\text { prospect sample. }\end{array}$ & 3.60 & .60 & 3.89 & 38.65 & 57.46 & 7,372 & 7,647 & Do. \\
\hline $\begin{array}{l}\text { Cumberland No. 1, Kem- } \\
\text { merer bed. }\end{array}$ & 5.25 & & 4.69 & 43.91 & 51.40 & & & W. S. Robinson. $b$ \\
\hline $\begin{array}{l}\text { Cumberiand No. 2, Kem- } \\
\text { merer bed. }\end{array}$ & 5.13 & & 3.69 & 43.22 & 53.09 & & & Do. \\
\hline $\begin{array}{l}\text { Spring Valley No. 1, Spring } \\
\text { Valley bed. }\end{array}$ & 7.16 & & 3.88 & 42.80 & 53.32 & & & Do. \\
\hline $\begin{array}{l}\text { Kemmerer, main Kem- } \\
\text { merer bed. }\end{array}$ & 7.51 & 1.39 & 3.87 & 41. 73 & 54.40 & 6,870 & 7,628 & T. M. Stanton. \\
\hline Kemerer, lower bed....... & 3.65 & 1.07 & 4.09 & 41.80 & 54.05 & 7,102 & 7,527 & Do. \\
\hline $\begin{array}{l}\text { Cumberlànd No. } 1 \text {, main } \\
\text { Kemmerer bed. }\end{array}$ & 6.00 & .43 & $4.51^{\circ}$ & 43.53 & 51.90 & 6,815 & 7,452 & Do. \\
\hline $\begin{array}{l}\text { Diamondville, main Kem- } \\
\text { merer bed. }\end{array}$ & 4.61 & .49 . & 4.07 & 43.06 & 52.87 & 7,202 & 7,654 & Do. \\
\hline $\begin{array}{l}\text { Richardson, Spring Valley } \\
\text { bed. }\end{array}$ & 13.67 & .94 & 5.09 & 42.53 & 52.38 & 6,305 & 7,530 & Do. \\
\hline $\begin{array}{l}\text { Kemmerer, Willow Creek } \\
\text { bed. }\end{array}$ & 4.77 & .77 & 2.73 & 38.54 & 58.73 & 7,501 & 7,994 & Do. \\
\hline$\Lambda$ verage of Benton coals $c$.. & 5.69 & .83 & 3.76 & 41.54 & 54.61 & 7,133 & 7,666 & \\
\hline
\end{tabular}

a The heating power of Wyoming coal and oil: Special Bull. University of Wyoming, January, 1895. $b$ 'These analyses, made in the laboratory of the Union Pacific Coal Company, were selected from many hundreds by Mr. Frank Manley, chief engineer, as typical.

c'l'he averages are not entirely satisfactory in the volatile combustible and fixed carbon columns, as it is cvident from a comparison of analyses that two different methods have been used in the determination of these values. 'The Slosson and Knight values are always higher in fixed carbon than the Stanton values, without any corresponding increase in the calorifie value. Thus in the Almy coals where the moisture is the same Stanton finds a value 6,305 calories from a simple showing "Fixed carbon 44.72 per cent," while slosson and Knight obtained a value of 6,393 calories from a sample showing "Fixed carbon 54.98 per cent." 
Proximate analyses of coals from southern Uinta County, Wyo.-Continued.

COALS OF UPPER MONTANA-LARAMIE AGE, INCLUDING ADAVILLE AND TWIN CREEK COALS.

\begin{tabular}{|c|c|c|c|c|c|c|c|c|}
\hline Source of sample. & Ash. & $\begin{array}{l}\text { Sul- } \\
\text { phurr. }\end{array}$ & $\begin{array}{l}\text { Mois- } \\
\text { ture } \\
\text { in air- } \\
\text { dried } \\
\text { ash- } \\
\text { free } \\
\text { sam- } \\
\text { ple. }\end{array}$ & $\begin{array}{l}\text { Vola- } \\
\text { tile } \\
\text { comi- } \\
\text { busti- } \\
\text { bles. }\end{array}$ & $\begin{array}{c}\text { Fixed } \\
\text { car- } \\
\text { bon. } \\
\\
.\end{array}$ & $\begin{array}{c}\text { As } \\
\text { deter- } \\
\text { mined. }\end{array}$ & $\begin{array}{l}\text { Cal- } \\
\text { culat- } \\
\text { ed for } \\
\text { air- } \\
\text { dried. } \\
\text { ash- } \\
\text { free } \\
\text { sam- } \\
\text { ple. }\end{array}$ & Analyst. \\
\hline $\begin{array}{l}\text { Ution Pacific Coal Co., } \\
\text { Twin Creek mines. }\end{array}$ & 6. 30 & $\ldots \ldots$ & 9.16 & 37.59 & 53.25 & $\cdots$ & $\cdots$ & \multirow{4}{*}{$\begin{array}{l}\text { F. M. Stanton. } \\
\text { Do. }\end{array}$} \\
\hline Adaville mine............. & 1. 18 & 0.50 & 9.20 & 41.93 & 48.87 & 5,440 & 6,612 & \\
\hline Lazent mine............. & 5.26 & 1. 18 & 14. 14 & 41.79 & 44.07 & 5,631 & 6,396 & \\
\hline $\begin{array}{l}\text { Average of upper Mon- } \\
\text { tana-l.aramie roals. }\end{array}$ & 4. 25 & .84 & 10.83 & 40.44 & 48.73 & 5,535 & 6,502 & \\
\hline
\end{tabular}

COALS OF EVANSTON OR POST-LARAMIE AGE, INCLUDING ALMY COALS.

\begin{tabular}{|c|c|c|c|c|c|c|c|c|}
\hline Almy No. 5, lower 8 feet.... & 7.22 & 0.21 & 10.02 & 42. 27 & 47. 70 & 5,804 & 6,665 & F. M. Stanton. \\
\hline Michigan-Wyoming mine.. & 16.15 & {$[4.45]$} & 9.36 & 45.92 & 44. 72 & 4,898 & 6,365 & Do. \\
\hline Almy No. $6 . \ldots \ldots \ldots \ldots . . . .$. & 6.55 & .29 & 8.29 & 37.56 & 54.15 & 6,553 & 7,012 & Slosson and Knight.b \\
\hline Almy No. 5, lower 9 feet.... & 8.00 & .44 & 8.07 & 39.20 & 52.73 & 6,340 & 6,891 & Do. \\
\hline Almy No. 7, upper seam... & 9.00 & $\ldots \ldots$ & 8. 10 & 38.33 & 53.57 & 6,145 & 6,753 & Do. \\
\hline Almy No. 7, lower senm ... & 5.90 & .65 & 9.37 & 35.65 & 54.98 & 6,017 & 6,393 & Do. \\
\hline Almy No. 5 , middle $2 \frac{1}{2}$ feet. & 9.25 & $\ldots \ldots$ & 7.54 & 40.20 & 52.26 & 5,933 & 6,538 & Do. \\
\hline $\begin{array}{l}\text { Almy, average of three an- } \\
\text { nlyses. }\end{array}$ & 7. 46 & & 6. 29 & 40.33 & 53.38 & & & Persifor Frazier, jr.c \\
\hline Almy $\ldots \ldots \ldots \ldots \ldots \ldots \ldots$ & 8.8 .3 & & 8.85 & 43. 42 & 47.73 & & & O. D. Allen.t \\
\hline Do..... & 8.88 & & 8.98 & 43.04 & 47.08 & & & Do. \\
\hline Do $\ldots \ldots \ldots \ldots$ & 6. 30 & & 9.15 & 37.59 & 53.26 & & & J. V. Hodge.c \\
\hline$\Lambda \operatorname{lm} y$ No. $5 \ldots \ldots \ldots$ & 9.70 & .10 & $9 . ' 64$ & 44.73 & 45. $(i 3$ & & & J. S. Cory.f \\
\hline Almy No. $6 . \ldots \ldots \ldots \ldots \ldots$ & 2.80 & .14 & 9.97 & 44. 10 & 45.93 & & & Do. \\
\hline A verage of Evanston coalsc & 8. 16 & g. 30 & 8.73 & 40.95 & 50.24 & 5,956 & 6,660 & \\
\hline
\end{tabular}

a Mineral Resources of the United States [for 1882], U. S. Geol. Survey, 1883, p. 88.

$b$ The heating power of Wyoming coal ard oil: Special bull. Ulive rsity of Wyoming, January, 1895. $c$ [Fourth Ann.] Prelim. Rept. U.S. Geol. Survey Wyoming and contiguous Territories, 1871, p. 184. d Rept. Geol. Expl. 40th Par., vol. 3, 1870, p. 473.

c [Fourth Ann.] Prelim. Rept. U. S. Geol. Survey Wyoming and contiguous 'Territories, 1871, p. 321. $f$ Chemist in charge, Dept. Mines, World's Columbian Exposition.

o Omitting Michigan-Wyoming mine, which probably represents an accidental sulphur ball.

From these analyses and the general physical character of the coals, the Benton coals are to be regarded as high-grade bituminous, the Evanston coal as low-grade bituminous, and the upper Montana-Laramie (Adaville and Twin Creek coals) as high-grade black lignites.

According to the carbon-hydrogen ratio classification of coals recently proposed by M. R. Campleell, $a$ these coals fall in the following groups:

The Willow Creek conl, of Benton age, falls in Group G, which includes the Upper Freeport and Pittsburg conls of northern West Virginia, Kanawha Valley coals, high-grade Kentucky coals, and Alabama coals.

The Kemmerer (Benton) coal belongs to Group H, which includes Indian Territory coals, Kansas coals, high-grade Illinois, Iowa, and Missouri coals, and second-grade Kentucky coals. 
The Evanston coals belong to Group I, which includes the great majority of Iowa, Illinois, Missouri, and Indiana coals, and some bituminous coals from Wyoming and Montana:

The Adaville-Twin Creek coals a fall in Group J with the Gallup (N. Mex.) and Boulder (Colo.) black lignites.

Slosson has already shown that from the standpoint of carbon content and calorific value the Benton coals of this region are the best coals in Wyoming. According to the analyses made at the United States Geological Survey coal-testing plant of samples collected by Fenneman and Gale in the Routt County (Colo.) field and by J. A. Taff in the Coalville and Castle Gate field in Utah, given elsewhere in this volume, the coals found in this region in the Benton are better than the best bituminous coals in these Colorado and Utah fields, but higher carbon and fuel values are shown in the latter fields in portions of the beds which have been altered to "anthracite" or "natural coke" by dikes or flows. Similarly the analyses made of the samples collected by Schrader and Shaler in the Gallup (N. Mex.) field show that on the whole the Benton coals of Wyoming are of the same grade as the best coals of that region. They are much better than the Red Lodge (Mont.) conls tested at St. Louis. $b$ On the whole, the Benton coals of the Uinta County region may be said to belong near the top of the group containing the best bituminous coals of the Rocky Mountain region.

\section{OIL.}

Oil has been found in southern Uinta County in springs on Hilliard Flat (sec. 4, T. 1d N., R. 119 W., and sec. 33, T. 14 N., R. 119 W.); at Aspen tunnel (sec. 12;T. 14 N., R. 119 '?., and sec. 7,T. 14 N., R. 118 W.); 3 miles north of Aspen tunnel, at Carter oil springs (sec. 31, T. 15 N., R. 118 W.); in springs and wells on the south branch of Twin Creek (T. 21. N., R. 117 W.), and in wells near Spring Valley (Tps. 14 and 15 N., R. 118 W.).

\section{HISTORY OF DEVELOPMENT.}

The sil spring near Hilliard, in the NW. $\frac{1}{4}$ sec. 4, T. 13 N., R. 119 W., was doubtless well known to the trappers who first built the trading post of Fort Bridger, but the first published account was the result of an examination made by the Mormons in their pioneer journey to Great Salt Lake in 1847. W. Clayton, c who accompanied this expedition, published in 1848 a little book, which was known for years as the "Mormons' Guide Book." containing the following account:

About a mile from this place [the crossing of the road over Sulphur Creek] in a southwest course is a "Tar" or "Oil" Spring, covering a surface of several rods of ground. A wagon trail runs within a short distance of it. It is situated in a small hollow, on the left of the wagon trail, at a point where the trail rises to a higher bench of land. When the oil can be obtained free from sand, it is useful to oil wagons. It gives a nice polish to gunstocks, and has been proved to be highly beneficial when applied to sores on horses, cattle, etc.

This spring is mentioned in the accounts of Stansburyd and Engelmann,e but their statements do not differ materially from the earlier account of Clayton. It is reported that Brigham Young caused a shallow well to be dug at this point, and the locality is now known as the Brigham Young oil well or spring. The oil was skimmed off the surface of

a Calculated on the excessive air-drying loss reported in the Adaville analyses, the Adaville coal belongs high in Group 1, while the Lazeart coal belongs in Group J. According to physical characters and general fuel value, these two coals clearly belong together and are to be regarded as high-grade black lignites. An examination of the two original analyses will suffice to show that the air-drying losses reported for these two coals are not entirely comparable. New analyses are now being made.

b Bull. U. S. Geol. Survey No. 261, 1905, p. 49 .

c Clayton, W., The Latter-Day Saints' Emigrants' Guide: being a Table of Distances, showing all the springs, creeks, rivers, hills, mountains, camping places, and all other notable places, from Council Bluffs, to the Valley of the Great Salt Lake, etc. St. Louis, 1848, pp. 18, 24.

$d$ Stansbury, Capt. Howard, Exploration and Survey of the Valley of the Great Salt Lake of Utah, 1852 , p. 280.

e Engelmann, H., Preliminary Report on the Geology of the country between Fort Bridger and Camp Floyd, Utah Territory, accompanying Simpson's Report on Wagon Routes in Utah Territory, 35th Cong., 2d sess., Senate Ex. Doc., vol. 10, No. 40, 1859, p. 52. 

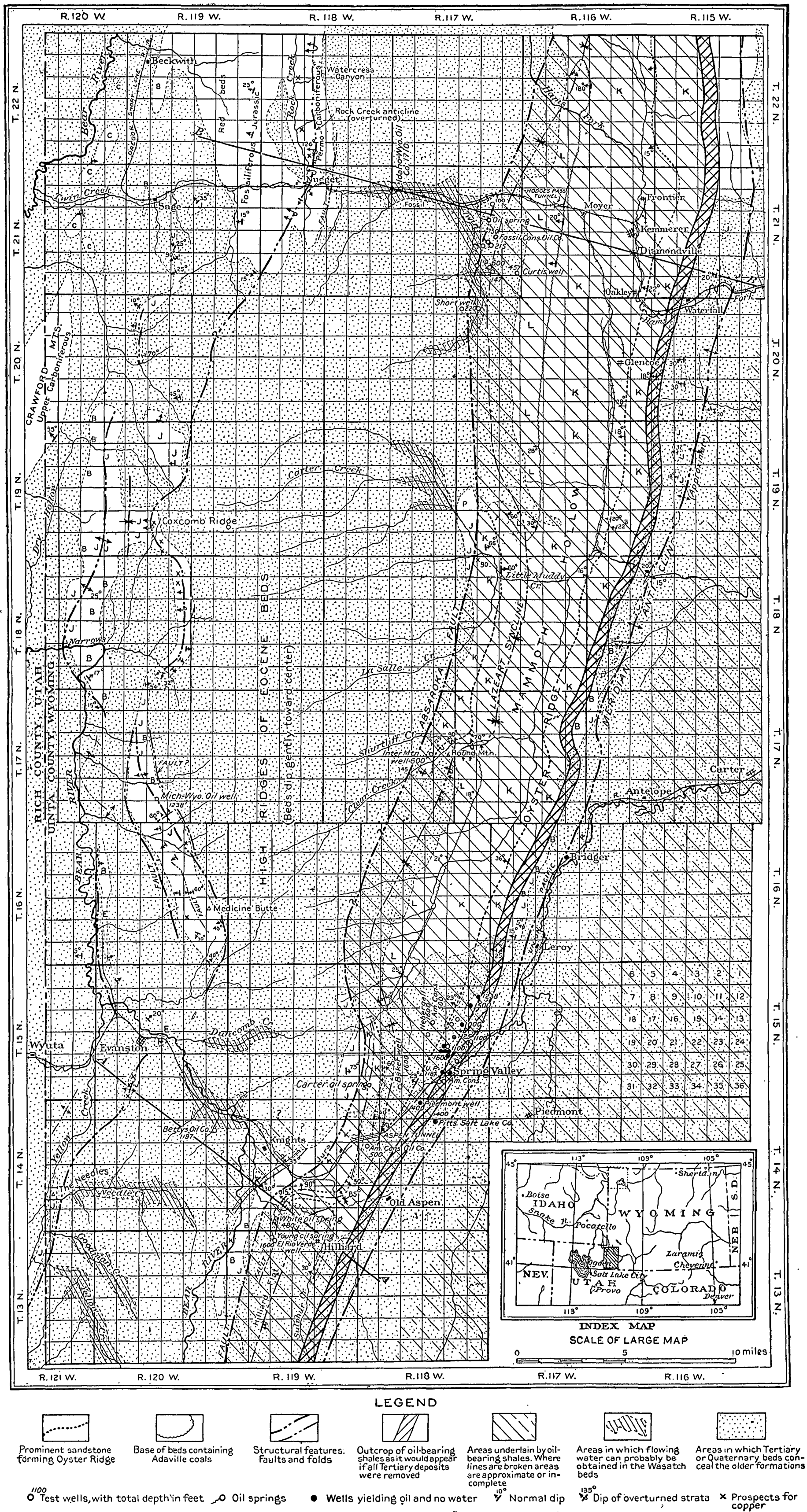

\footnotetext{
E Evanstón L. Laramie K. Cretaceous' B. Bear River J.Jurassic P. "Permo-Carboniferous" C. Upper Carboniferous
} 
the water in this well, sold to emigrants, and carried in small quantities to Salt Lake City.

In 1867 Judge C. M. White began operations at a spring in the NW. $\frac{1}{4}$ sec. 33 , T. 14 N., R. $119 \mathrm{~W}$., now known as the White oil spring. He dug a large hole and skimmed off the oil, which he sent to Salt Lake and sold to tanners. He began drilling in 1867 , but abandoned the hole in 1868 at a depth of 480 feet. Later the Evanston Oil Company sunk a well at this placs, but it was likewise abandoned at a depth of a few hundred feet.

The Carter oil spring locality became of importance in 1868, when in driving a tunnel for coal a slight flow of petroleum ( 8 to 10 gallons a day) was obtained and the discharge of the spring ceased. This oil was collected and sold to the Union Pacific Railroad and to neighboring coal mines for lubricating purposes. - It is reported that Judge Carter, then sutler at Fort Bridger, attempted to drill a hole here, but the well was abandoned without results. This spring was incidentally mentioned by Meek $a$ in 1871 and a short statement regarding it was published by Emmons $b$ in 1877, but the first account of importance is that published by Ricketts $c$ in 1888 .

The oil springs along the south fork of 'Twin Creek in T. 21 N.; R. 117 W., are perhaps referred to in Lander's general statement that in the mountains along the divide in latitude $42^{\circ} \mathrm{N}$. there are "beds of coal, iron, and salt, and a spring of peculiar mineral oil which by chemical procsss may be made suitable for lubricating machinery." At any rate, the map of his explorations in 1857 shows that he passed up Twin Creek and over Hodges Pass.d Operations were begun here by the Twin Creek Land and Oil Company in 1885. This company drilled before 1887 two wells, one 110 feet deep and the other 185 feet. Both yielded a large flow of brakish sulphur water, with a little oil and gas. The deeper of the two is now open and is commonly known in the field as the Clark well, from Senator C. D. Clark, who was interested in this company. The oil is dark and heavy. The gravity is given by the Union Pacific Railroad $e$ as $26.75^{\circ}$ Baumé, by Slosson $f$ as $19.7^{\circ}$ Baumé.

In the fall of 1900 the Union Pacific Railroad began a water well at Spring Valley, Wyo., and October 14 struck a white sand containing a very high-grade oil between 424 and 463 feet. Oil was struck again in December between 567 and 575 feet and the following May between 1,147 and 1,159 feet. Water is reported in this well at a depth of about 300 feet, but it was brackish and the well was capped and abandoned. Intense excitement followed this find and as the greater part of the land in this scction was unoccupied Government land the whole region was soon staked out as petroleum claims under the placer-mining laws. A large part of these were purely speculative claims, which the owners had no intention of developing. The Government Land Office took the important step of removing from entry, except under the mining laws, all Government lands in an area very nearly equal to that shown on PI. XI, and refused to issue to the Union Pacific Railroad patents for the unpatented odd ssctions in the railroad grant within the limits of this reservation until after December 1, 1903, when the issuance of patents was to be determined by the "then known character of the land." In the words of the Department: $g$

The purpose of this order is to permit, encourage, and protect, so far as tho Department can do so, but within the time herein named, the exploration and exploitation of the unpatented alternate oddnumbered sections within s.zid railroad land grant which are within the limits hereinbelore specifically described, and of the public lands within said limits, for the purpose of ascertaining and demonstrating whether, as claimed, such lands or any of them are mineral in character, in that they

a Meek, F. B. [Fourth Ann.], Preliminary Rept. U. S. Geol. Survey of Wyoming, 1871, p. 306. $b$ Emmons, S. F., Rept. U. S. Geol. Explor. 40th Par., vol, 2, 1877, p. 252

c Ricketts, Louis D., Ann. Rept. 'l'erritorial Geologist of Wyoming for 1887, 1888, pp. $23,42$.

$d$ Lander, F. W., Preliminary Report upon Explorations west of South Pass for a suitable location for the Fort Kearney, South Pass, and Honey Lake wagon route, 35th Cong., 2d sess., Senate Ex. Doc., vol. 10, No. 36,1859 , p. 33 .

e Min. Res. U. S. for 1885,1886, p. 154.

f Slosson, E. E., School of Mines, Univ. of Wyo., Petroleum ser., Bull. No. 3, 1899, p. 31.

$\theta$. Decisions of the Department of the Interior and Ceneral Land Office in Cases relating to Public Lands, vol. 33,1903, p. 50 . 
are chiefly valuable for their oil or other mineral deposits; but in justice to the roilroad company, whose line of rail road has long since been completed in conformity with the land-grant act, and in justice to others who may desire to take any of the public lands within said limits under any of the public-land laws other than the mining laws, it is necessary that this order of suspension shall not be operative longer than until December 1,1903 , that being deemed ample time within which, in addition to the exploration and exploitation heretofore had, to fairly develop the character of these lands.

The effect of this order was, on the one hand, to stimulate prospectors to attempt to develop this field, and, on the other, it is claimed, to make the Union Pacific Railroad hinder the development in such way as it might, being the one line of transportation in this region. Certain cases affecting sec. 23, T. 15 N., R. 118 W., and sec. 33, T. 14 N., R. 119.W., were heard before a special examiner in the district land office August 23 and 25, 1904, and the decision rendered that these tracts were not "known mineral lands," and that patent should be issued to the Union Pacific Railroad in accordance with the terms of its land grant. With the termination of this land contest, it is asserted, the railroad has offered freight facilities which will materially aid in the development of the field. The following table gives the wells drilled in this field up to the present time: 
List of test wells for oil in southern Cinta County, Wyo.

\begin{tabular}{|c|c|c|c|c|c|c|c|c|}
\hline Location. & 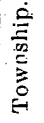 & 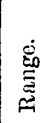 & Section. & $\begin{array}{l}\text { Name of well or } \\
\text { owner. }\end{array}$ & - Yrilled. & $\begin{array}{l}\text { Total } \\
\text { depth } \\
\text { in } \\
\text { feet.a }\end{array}$ & $\begin{array}{r}\text { Prod- } \\
\text { uet. } b\end{array}$ & Remarks. \\
\hline Hilliard (2 miles west)... & 13 & 119 & $4, N E \cdot \frac{1}{4}$ NE. $\frac{1}{4}$.. & $\begin{array}{l}\text { B righam Young oil } \\
\text { spring or well. }\end{array}$ & $1848 ?$ & 57 & $w, o$ & $\begin{array}{l}\text { Shallow well reported to have been sunk by order of Brigham } \\
\text { Young on site of oil spring. Yields a few gallons per day. }\end{array}$ \\
\hline Do... & 13 & 119 & $4, N W \cdot \frac{1}{1} N W \cdot \frac{1}{4} \ldots$ & El Rio Verde Oil Co.. & 1902 & 1,600 & $\mathbf{W}$ & $\begin{array}{l}\text { Sunk near Brigham Young oil spring. This well is located } \\
\text { on upper flank of an overturned syncline, and stra ta at bot- } \\
\text { tom of well are higher geologically than those near surface. }\end{array}$ \\
\hline & & & $4, \mathrm{NW} \cdot \frac{1}{4} \mathrm{NW} \cdot \frac{1}{4}$ & J. R. White. . . . . . . & 1902 & 100 & $w, o$ & $\begin{array}{l}\text { Between El Rio Verde well and Brigham Young spring. } \\
\text { Small amount of oil. }\end{array}$ \\
\hline Hilliard (2 miles northwest). & 14 & 119 & 33, SE. $\frac{1}{1} \mathrm{NW}+\ldots$ & $\begin{array}{l}\text { Judge White oil } \\
\text { spring. }\end{array}$ & 1867 & $10 \pm$ & $\mathrm{W}, \mathrm{O}$ & $\begin{array}{l}\text { Shallow pits in which oil collected and was skimmed from } \\
\text { time to time from surface of water. }\end{array}$ \\
\hline Do... & 14 & 119 & $33, \mathrm{SE} \cdot \frac{1}{1} \mathrm{NW} \cdot \frac{1}{4}$ & Judge White well.... & $1867-1.868$ & 480 & $w$ & $\begin{array}{l}\text { Seepage of oil. Ricketts gives depth of this well as } 250 \text { feet } \\
\text { and date } 1869 \text {. }\end{array}$ \\
\hline Do.................... & 14 & 119 & 35, SE. $\frac{1}{4}$ NW. $\frac{1}{4} \ldots$ & Evanston Oil Co ..... & 1884 & 484 & $w$ & \\
\hline Do $\ldots \ldots \ldots, \ldots, \ldots, \ldots$ & 14 & $119^{\circ}$ & 33, SE. $\frac{1}{4}$ NW. $\frac{1}{4} \ldots$ & Consolidated Oil Co.. & $1902-1903$ & 80 & W & Seepage of oil. \\
\hline Knight ( 3 miles west) ....... & 14 & 120 & $12, N W \cdot \frac{1}{4} S W \cdot \frac{1}{4} \ldots$ & $\begin{array}{l}\text { Betty's Oil and De- } \\
\text { velopment Co. }\end{array}$ & $1902-1904$ & 1,200 & w & $\begin{array}{l}\text { Flowing fresh water of good quality at } 700,1,020 \text {, and } 1,197 \\
\text { feet. Flows } 30 \text { gallons per minute. Well in synclinal basin } \\
\text { and entirely in the Eocene. (Pl. XII A.) }\end{array}$ \\
\hline Altamont.... & & & & $\begin{array}{l}\text { Aspen tunnel (Union } \\
\text { Pacific Railroad Co) }\end{array}$ & $1900-1902$ & & $\mathrm{w}, \mathrm{O}$ & $\begin{array}{l}\text { Considerable quantities of water and seepage of oil } 1,600 \text { feet } \\
\text { from west end of tunnel. Oil represents seepage from Oil- } \\
\text { spring fault. }\end{array}$ \\
\hline Altamont (1 mile east)...... & 14 & 118 & $18, \mathrm{NE} \cdot \frac{1}{2} \mathrm{NW} \cdot \frac{1}{4} \ldots$ & Consolidated Oil Co.. & 1902 & 500 & & $\begin{array}{l}\text { Well too shallow to reach oil-bearing shales in the Benton } \\
\text { formation. Large amount of water reported near surface. }\end{array}$ \\
\hline Spring Valley (2 miles south) & 14 & 118 & $10, N W \cdot \frac{1}{4}$ NE. $\frac{1}{4}$. & $\begin{array}{l}\text { Pittsburg-Salt Lake } \\
\text { Oil Co. }\end{array}$ & $1902-1903$ & 1,283 & $\mathrm{o}$ & $\begin{array}{l}\text { Large quantities of water are reported in this well at } 805 \text { feet. } \\
\text { Oil was found at } 862 \text { and } 1,005 \text { in sand beds in a gray shale. } \\
\text { The oil is heavy and black and quite different from that in } \\
\text { the Benton shales. The well starts below the Benton oil } \\
\text { shales, and the oil-bearing strata are Jurassic. }\end{array}$ \\
\hline $\begin{array}{l}\text { Sp-ing Valley } \quad\left(1 \frac{1}{2} \text { miles }\right. \\
\text { southwest. }\end{array}$ & 14 & 118 & $4, \mathrm{NE} \cdot \frac{1}{4} \mathrm{NE} \cdot \frac{1}{4} \cdot$ & Piedmont Oil Co... & $1902-1903$ & 500 & $w$ & $\begin{array}{l}\text { Small quantities of water. Well not deep enough to reach } \\
\text { oil-bearing shales. }\end{array}$ \\
\hline Spring Valley ( 3 miles west). & 15 & 118 & $31, \mathrm{SW}: \frac{1}{4} \mathrm{NE} \cdot \frac{1}{4} \ldots$ & Carter oil spring..... & is6s & & $\mathrm{O}$ & $\begin{array}{l}\text { Shaft and shallow pits reported to have been dug here yielded } \\
8 \text { to } 10 \text { gallons of heavy black oil per day. Gravity } 21.5^{\circ} \\
\text { Baumé (Slosson). }\end{array}$ \\
\hline & & & a Approximate. & & & & $V=w$ & $\mathrm{r} ; \mathrm{O}=\mathrm{oil} ; \mathrm{G}=$ gas. \\
\hline
\end{tabular}


List of test wells for oil in southern Uinta County, Wyo.-Continued.

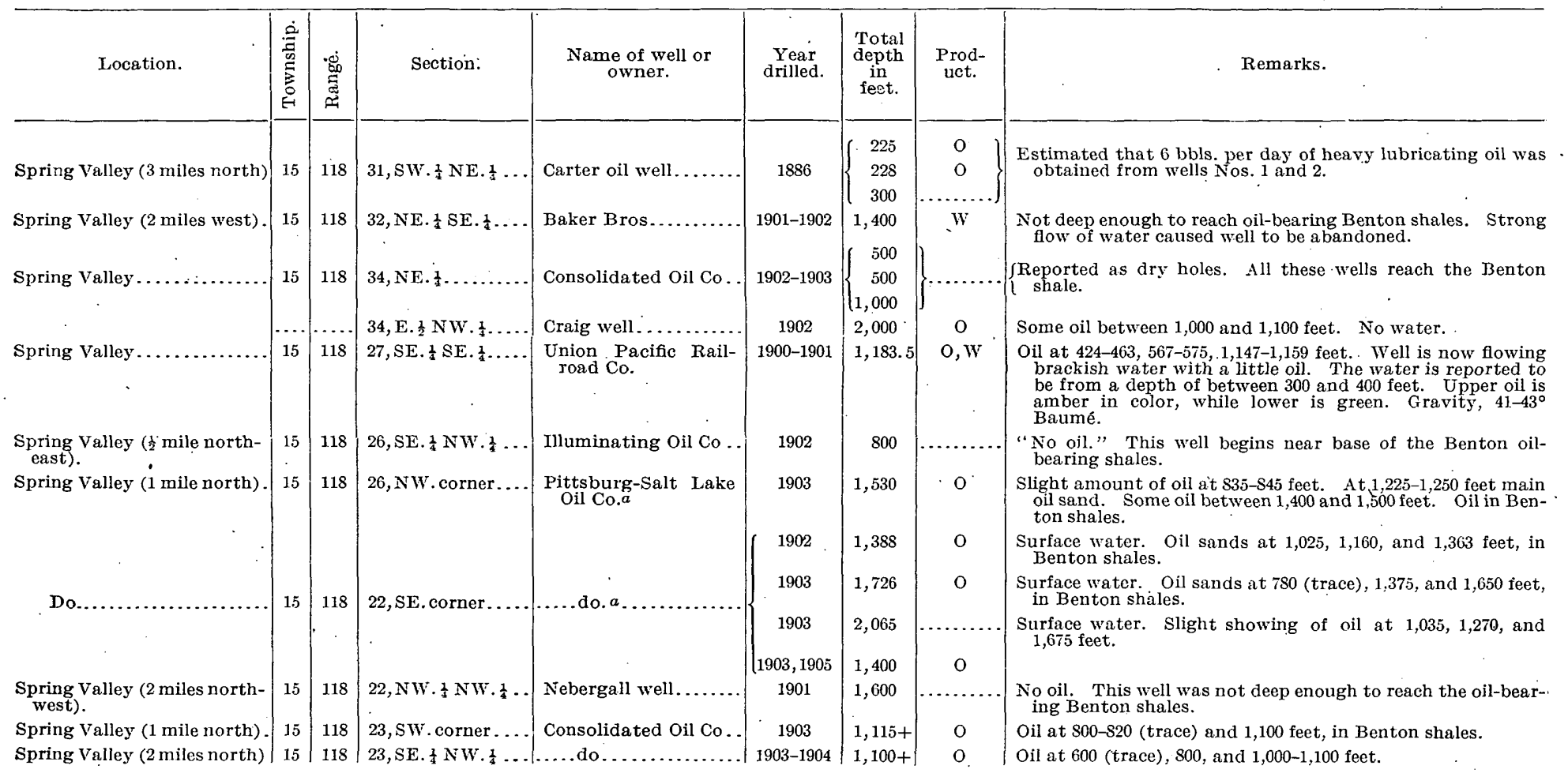


List of test wells for oil in southern Uinta County, Wyo.-Continued.

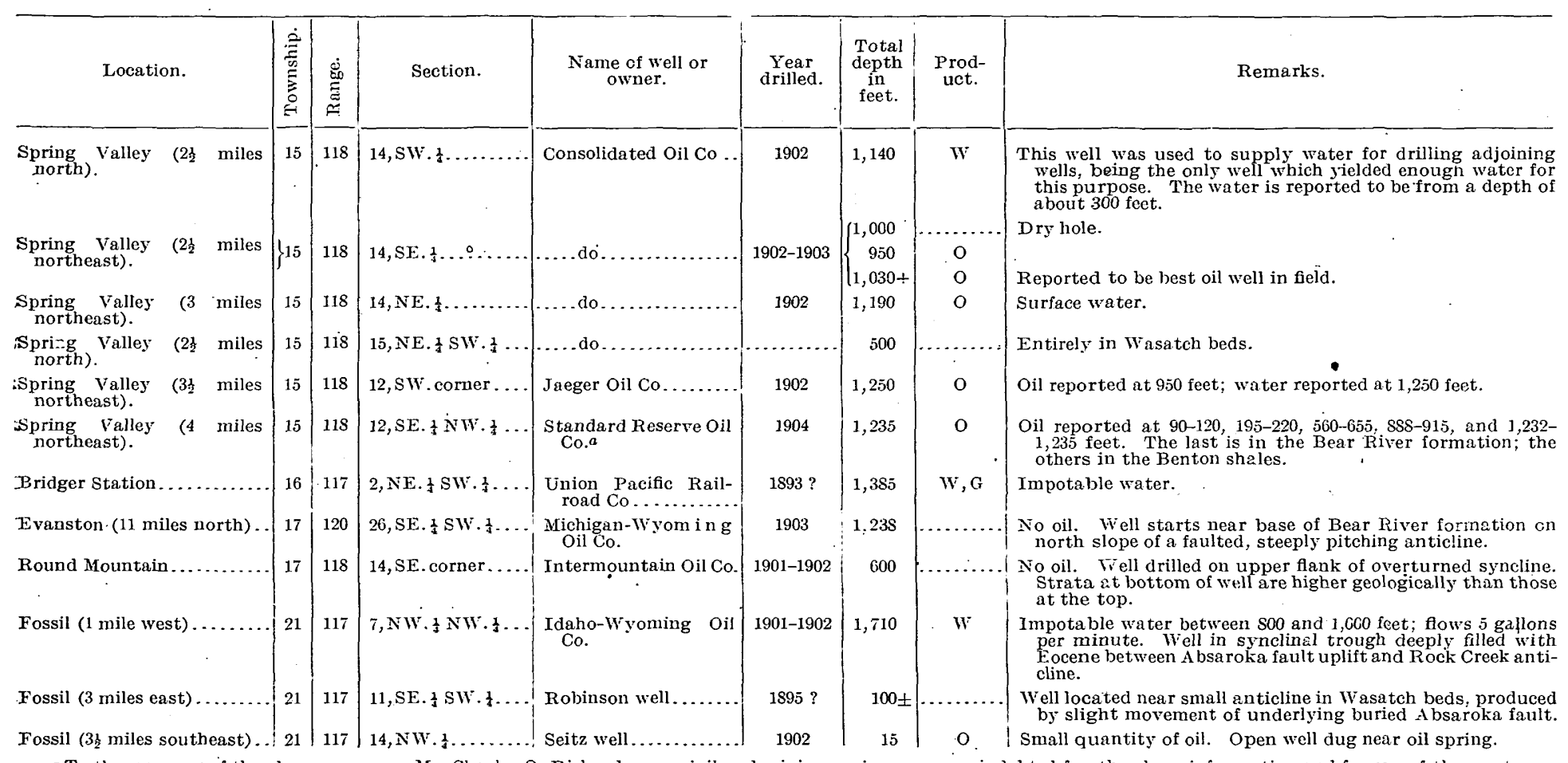

a To the manager of the above company, Mr. Charles O. Richardson, a civil and mining engineer, we a re indebted for the above information and for one of the mostcomplete oil-well records obtained in this field. 'This record will be published in the complete report now in preparation. 
List of test wells for oil in southern Uinta County, Wyo.-Continued.

\begin{tabular}{|c|c|c|c|c|c|c|c|c|}
\hline Location, & 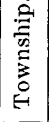 & 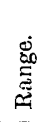 & Section. & $\begin{array}{l}\text { Name of weil } \mathrm{cr} \\
\text { owrer. }\end{array}$ & $\begin{array}{l}\text { Year } \\
\text { drilled. }\end{array}$ & $\begin{array}{l}\text { Total } \\
\text { depth } \\
\text { in } \\
\text { feet. }\end{array}$ & $\begin{array}{l}\text { Prod- } \\
\text { uct. }\end{array}$ & Remarks. \\
\hline \multirow[t]{3}{*}{ Fossil (4 miles southeast)... } & \multirow[t]{3}{*}{21} & 117 & \multirow[t]{2}{*}{23, NE. $\frac{1}{4}$ NE. $\frac{1}{4} \cdots}$. & \multirow{3}{*}{$\begin{array}{l}\text { Fossil Consolidated } \\
\text { Oil Co. } \\
\left\{\begin{array}{l}\text { Twin Creek Land and } \\
\text { Oil Co. } \\
\text { Twin Creek Land and } \\
\text { Oil Co. (Clark well). }\end{array}\right.\end{array}$} & 1902 & 750 & $W, O$ & Oil reported at 520 feet. \\
\hline & & \multirow{2}{*}{117} & & & 1885 & 100 & $W, O, G$ & $\begin{array}{l}\text { Flowing brackish sulphur water with a little oil and gas. } \\
\text { Well caved. }\end{array}$ \\
\hline & & & $23, \mathrm{SW} \cdot 1 \mathrm{NE} \cdot \frac{1}{4} \cdot$ & & 1887 & 185 & $W, O, G$ & $\begin{array}{l}\text { Flowing brackish sulphur water with a little oil and gas. } \\
\text { ivell still open. }\end{array}$ \\
\hline Fossil ( $4 \frac{1}{2}$ miles southeast)... & 21 & 117 & 27, NE. $\frac{1}{4}$ SE. $\frac{1}{4} \ldots$ & $\begin{array}{l}\text { Utah-Wyoming Oil } \\
\text { Co. }\end{array}$ & $1902-1903$ & 1,110 & $\mathrm{~W}, \mathrm{G}$ & Flowing brackish sulphur water with some gas. \\
\hline Fossil ( 5 miles southeast)... & 21 & 117 & $26, \mathrm{SW} \cdot \frac{1}{4} \mathrm{SE} \cdot \frac{1}{4} \ldots$ & Globe Oil Co....... & $1903-1904$ & 600 & $\mathrm{~W}, \mathrm{G}, \mathrm{O}$ & $\begin{array}{l}\text { Flowing brackish sulphur water with some gas and a trace o } \\
\text { oil. Well located in small syncline in Wasatch beds, pro- } \\
\text { duced by movement along Absaroka fault. }\end{array}$ \\
\hline Do.................... & 21 & 117 & $26, \mathrm{SW} \cdot \frac{1}{1} \mathrm{SE} \cdot \frac{1}{4} \ldots$ & Paraffine Oil Co... & $1902-1903$ & $14 \pi$ & W,o & Two wells. Flowing brackish sulphur water with a little oil. \\
\hline Fossil (6 miles southeast)... & 21 & 117 & 25 , SE. corner.... & Orlando Curtis.. & 1903 & 457 & & Drilled entirely in Laramie Cretaceous beds. \\
\hline Fossil (7 miles southeast)... & 20 & 117 & $6, \mathrm{SW} \cdot \frac{1}{4} \mathrm{SW} \cdot \frac{1}{3} .$. & G.Short........ & $1903-1904$ & 2,200 & & $\begin{array}{l}\text { Red beds from } 1,650 \text { to } 2,200 \text { feet. These are probably highly } \\
\text { inclined upper Jurassic (?) beds on the west side of Absa- } \\
\text { roka fault. (Pl. XII, B.) }\end{array}$ \\
\hline
\end{tabular}




\section{GEOLOGIC RELATIONS.}

The natural oil springs in this area occur in the region of profound disturbance along the Absaroka fault (Pls. XI, XII).

The Brigham Young, White, and Carter springs occur along a secondary fault just east of the main fault line. This secondary fault cuts the west end of the Aspen tunnel, and the oil seepage reported in this tunnel is to be regarded as essentially of the same character as that in the neighboring oil springs. In these cases the oil issues directly from faulted Cretaceous rocks, of Benton age, at a horizon stratigraphically 1,600 feet above the top of the black shales, which yield oil in the wells at Spring Valley. As these lower shales are about 1,000 feet thick, it would require a hole 2,600 feet deep at the fault line to prospect them fully if the strata were horizontal, but as they are highly inclined, wells drilled at the fault line must go to much greater depths. Where, as at Hilliard, the strata are overturned, a well at the fault line, like the El Rio Verde well, must drill through some of the strata twice, and such a location is to be avoided both because of the unnecessary duplication required and because the oil yield will be smaller than at greater distances from the fault, owing to loss by leakage along the fault line.

In the vicinity of Fossil the oil comes from a group of springs which, with the exception of occusional globules of oil, are of the type commonly found in the Eocene beds. The strata around these springs and for many feet below belong to the Wasatch. These beds show a gentle anticline with dips of about $5^{\circ}$, and the springs occur very near the axis. To the east, between this anticline and the outcrop of the coal-bearing Laramie beds, is a similar syncline. The geologic relations of the adjoining areas indicate conclusively that the position and direction of this anticline corresponds very nearly with those of the underlying Absaroka fault, and that it has doubtless been produced by a slight movement along this older axis (Pl. XII, B). The oil floating up through the water which has penetrated to the oil-bearing beds along the fault has naturally, in the fairly water-logged beds of the Wasatch, collected and found outlet along this low anticline, which is at the same time the highest point stratigraphically and the lowest point topographically, and is almost directly over the fault line. The Short Well penetrated red beds from 1,650 feet to the bottom of the well-2,200 feet-conclusively showing that it is situated west of the Absaroka fault. The other wells in this field obtained water, with a little gas and oil, in the Wasatch beds. The conditions here are manifestly unfavorable for the accumulation of oil in commercial quantitities.

c At Spring Valley in all wells except the one in sec. 10, T. 14 N., R. 118 W., which will be discussed later, oil is found in sandy layers in a black shale. Geologically this black shale occurs in the basal portion of the Benton. Failure to obtain oil has been recorded in three types of wells: (1). Those not deep enough to reach the oil-bearing strata, such as the Niebergall and Baker wells (Pl. XII, B); (2) those which, because of irregularities of the sandy layers in the shales, fail to develop oil, although it is found in adjacent wells (examples of this type are the Consolidated Oil Company's wells in the southwest corner of sec. 23 , T. 15 N., R. 118 W.); (3) those located on the outcrop of the shales, particularly those near the eastern edge, where the beds are less than 500 feet thick-such as the well of the Illuminating Oil Company in sec. 26 and the well on the west side of sec. 24, T. 15 N., R. $118 \mathrm{~W}$.

In general, no oil is found along the outcrop of this bed, but the amount increases with the dip. This, together with the irregularity shown in the position of the oil-bearing sands in adjoining wells and the fact that no water has been found in the oil-bearing beds, $a$ suggests

a. While water has been encountered in several wells in the Spring Valley region, in no case is it associated with the oil-bearing strata, and when the oil is pumped out no water follows. Water nccurs more or less abundantly in the Tertiary beds, as shown by the artesian wells in the. vicinity nf Fnssil and the Bettys well between Hilliard and Evanston. Where wells a re started in the Cretaceous, water is sometimns found in the upper part of the well, but the oil-bearing beds are dry. There are several conflicting reports of water encountered below the oil-bearing beds, but in these cases, assuming that water really was struck where reported, there seems to be no reason for believing that it is in any way associated with the oil.

Bull. 285-06-23 
that this oil has been formed from the shale in which it is found, and that the oil-bearing sands represent local sandy layers more or less perfectly surrounded by shales in which the oil has accumulated. This is the case also in the Boulder and Florence fields, although at those localities the shales are geologically younger. Where water is absent from the oil-bearing beds oil tends to move down the dip, and so far as the continuity of the porous beds allows will collect in the troughs of the synclines. This is apparently the case in this field, and the position of the syncline and the depth of the oil-bearing shale at its lowest point thus becomes one of considerable economic importance. At Hilliard the lowest point in the shale bed is over 11,000 feet from the surface and the dip of the beds is such that a deep well would be extremely difficult to sink. Between Hilliard and the Aspen tunnel the syncline rises and these' beds may be thoroughly prospected with a hole 2,500 to 3,000 feet deep. This is a good location, although the oil-spring fault to the west introduces a point of leakage and the deepening of the syncline to the south affords a lower point of accumulation. Because of the normal charactei of the syncline at this point, a well properly placed may be drilled entirely in nearly horizontal strata.

Northward the synclinal trough deepens rapidly, and at the Lazeart mine the oil shale is perhaps 10,000 feet from the surface. At Round Mountain the strata are overturned and faulted and the site is not favorable for an oil well. Between Round Mountain and the top of the Adaville beds, north of Little Muddy Creek, the synclinal trough rises. The rise is gradual, the syncline is normal, and the locality in these respects is the best in the region. However, the great depth of the oil-bearing shales-5,000 to 7,000 feet-is practically prohibitive. To the north the syncline sinks, and at the Oregon Short Line the lowest point of the oil-bearing beds is about 15,000 feet from the surface. Farther north the syncline rises, and in the long trough north of a point 10 to 15 miles north of Kemmerer the conditions are very favorable. The depth of the oil-bearing shale in the center of the syncline is such that wells could be readily sunk, and test holes here are likely to yield returns. This region is beyond that examined this year, but enough was learned regarding it to warrant the above suggestion. Moreover, oil springs are reported in this region, and it is hoped that they may be critically examined next year.

In general, in the region covered by this report the depth of the oil-bearing shales at the axis of the syncline is practically prohibitive, but the soft character of the strata suggests that the diminution of pore space; due to the pressure of the superincumbent beds, may be so great that the maximum accumulation of oil will be at some point on the limb of the syncline, between the axis and the outcrop. Indeed, though the oil-bearing shales underlie a much larger area, prospecting should be restricted to the region between the axis of the Lazeart syncline and the eroded edge of the bed on the west flank of the Meridian anticline (Pl. XI).

The well of the Pittsburg and Salt Lake Oil Company, in sec. 10, T. 14 N., R. 118 W., develops an entirely different horizon. It is so situated that after passing through the Wasatch beds it strikes the older rock below the oil-bearing Benton shale (PI. XII, $A$ ). It develops two oil-bearing sand beds in a light-blue shale, which is probably Jurassic and of the same age as the shale exposed on Twin Creek west of Nugget. The oil is black and more in the nature of a lubricating oil than that from the upper horizon. Prospecting for these lower horizons may well be carried on near and just west of the Meridian anticline. If in these lower strata water is also absent, the greatest yield will be found down the dip. In attempting to develop the shales of the same age on Twin Creek test wells should be located west of the outcrop and in such a position that 500 or 1,000 feet of red beds may be drilled through before reaching the shales. 


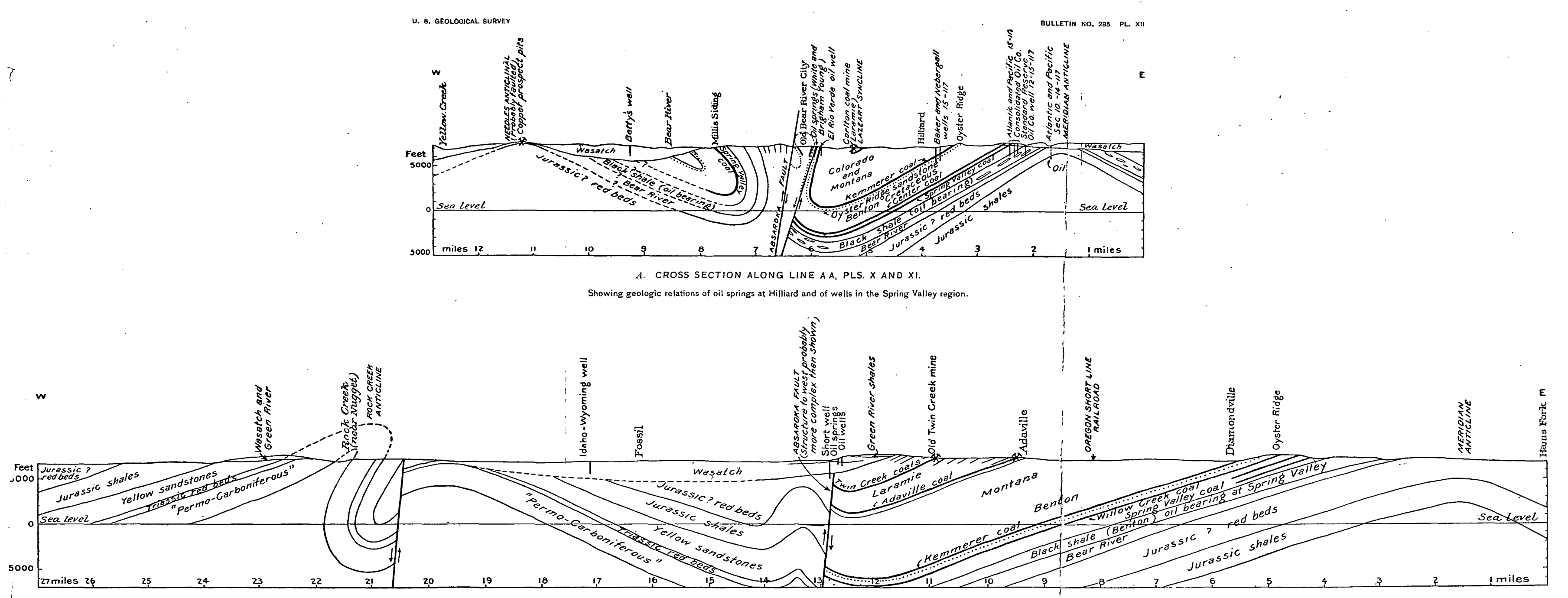




\section{QUALITY OF OIL.}

The oil obtained from the Brigham Young, White, Carter, and Fossil oil springs, and wells in their neighborhood, is a dark, heavy oil which has perhaps been derived in part from the Benton oil by the evaporation of its more volatile portions. The gravity of the Carter oil is given by Slosson $a$ as $21.5^{\circ}$ Baume. The gravity of the Fossil or Twin Creek oil is given by the Union Pacific Railroad $b$ as $26.75^{\circ}$ Baumé and by Slosson $a$ as $19.7^{\circ}$ Baume. The results of several analyses of the Spring Valley petroleum are given below:

\section{Analysis of oil from Union Pacific well at Spring Valley, Wyo.}

[By Thomas Price \& Son, San Francisco, 1901.]

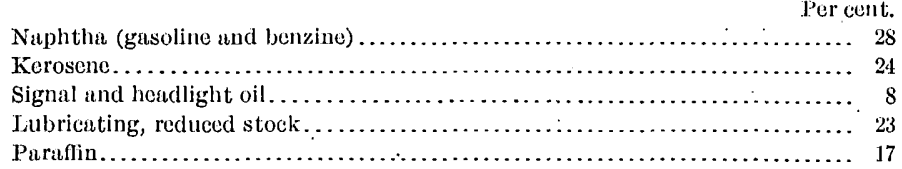

Analysis of oil from 650-foot sand of Union Pacific well at Spring Valley, Wyo.

[By Louis' Falkenau, San Francisco, 1901.]

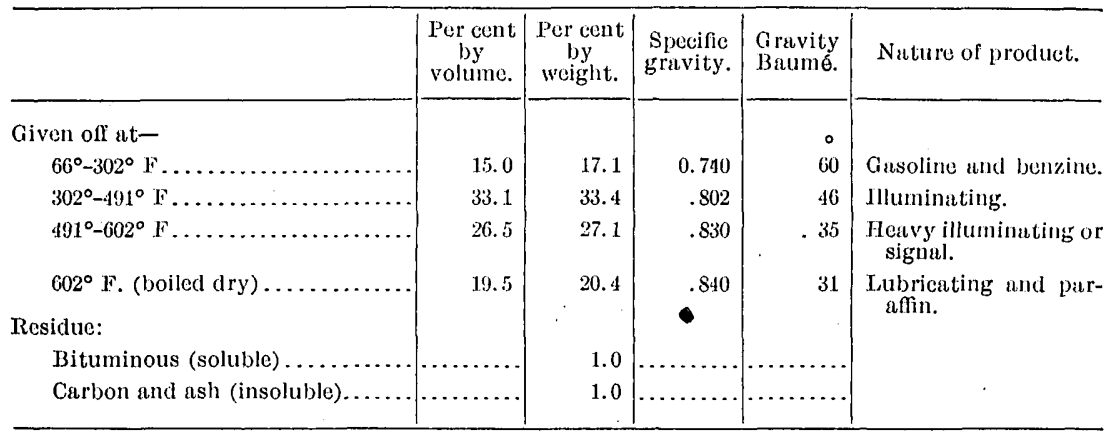

Specific gravity of crude at $66^{\circ}$ F., 0.825

Crude flashes at $66^{\circ} \mathrm{F}$.

$$
\text { Analysis of oil from Union Pacific well, Spring Valley, Wyo. }
$$

[By G. W. Gray, chemist, Standard Oil Company, ]902.]

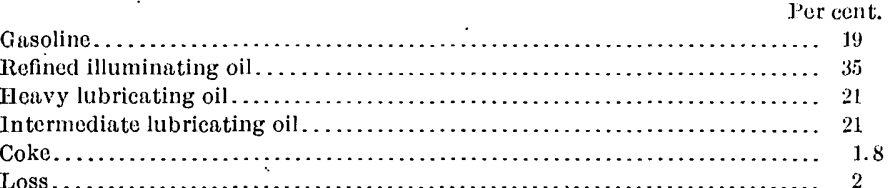

Sample baled from well upon first day of opening, 'Thursday, January 26, 1902, run into tank car, and taken from tank car Sunday, June 29, 1902.

Gravity, 0.8211 , or $41.5^{\circ}$ Baumé.

$a$ Slosson, E. E., Bull. School of Mines, Univ. Wyoming, petroleum series, No. 3, 1899, p. 31

$\checkmark$ Mineral Resources U. S. for 1885, U. S. Geol. Survey, 1886, p. 154 . 
Analysis of oil from Union Pacific well, Spring Valley, Wyo.

[By Wilbur C. Knight, professor of geology, University of Wyoming, 1902.]

\begin{tabular}{|c|c|c|c|}
\hline No. & Temperature given off. & $\begin{array}{l}\text { Specific } \\
\text { gravity. }\end{array}$ & Remarks. \\
\hline 1 & $77^{\circ}-130^{\circ} \mathrm{C} \ldots \ldots \ldots \ldots$ & 0.7230 & Oil at $15^{\circ} \mathrm{C}$. \\
\hline 2 & 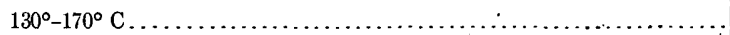 & .7540 & Do. \\
\hline 3 & $170^{\circ}-200^{\circ} \dot{\mathrm{C}} \ldots \ldots \ldots \ldots$ & .7800 & Do. \\
\hline 4 & 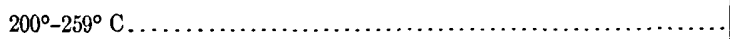 & .8040 & Do. \\
\hline 5 & 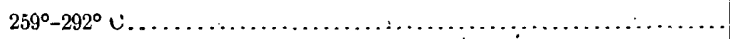 & .8190 & Do. \\
\hline 9 & 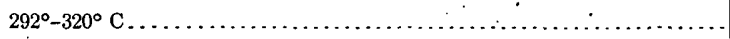 & .8340 & Do. \\
\hline 7 & 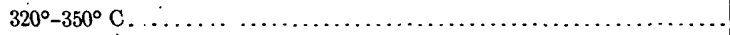 & .8470 & Oil at $18^{\circ} \mathrm{C}$ \\
\hline 8 & $350^{\circ}-370^{\circ} \dot{\mathrm{C}} \ldots \ldots \ldots \ldots \ldots \ldots \ldots \ldots \ldots \ldots$ & .8580 & Oil at $22^{\circ} \mathrm{C}$. \\
\hline 9 & $370^{\circ}-380^{\circ} \mathrm{C} \ldots \ldots .$. & .8640 & Do. \\
\hline 10 & 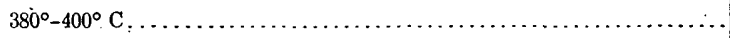 & .8880 & Do. \\
\hline
\end{tabular}

Specific gravity of crude oil, 0.81 .

Oil flashes at a point below $70^{\circ} \mathrm{F}$.

The above numbers represent tenths of the product, with the exception of the last, which was only half filled This means that with the ordinary method of distilling oils 95 per.cent of the crude.would be saved.

This oll will yield approximately, the following products: Gasoline and lighter ofls, 20 to 30 per cent; kerosene, 30 to 40 per cent; paraffin, 10 to 20 per cent. The remainder of the oil could be utilized to some extent for lubricating purposes.

This is a superior quality of crude for the production of gasoline and kerosene, but of little importance for lubricants For the lighter oils it is worth a little more than the ordinary crude from Colorado or Pennsylvania.

Analysis of oil from well of Pittsburg-Salt Lake Oil Company in sec. 22, T. 15 N., R. 118 W., 1 mile north of Spring Valley, Wyo.

[By C. Fomabery, Cleveland, Ohio, 1906.]

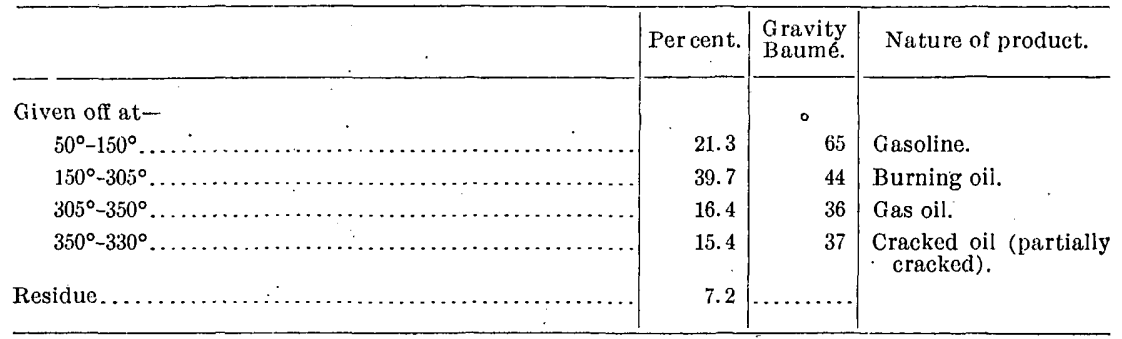

Specific gravity, 0.81 , or $44^{\circ}$ Baumé.

The oil begins to crack at $350^{\circ}$; of course this product is really gas oil. The distillates $305^{\circ}-350^{\circ}$, $350^{\circ}-330^{\circ}$, and the residue contain much paraffin. These oils become solid when cooled in tap water with paraffin, so the yield is large.

We refined some of the burning oil; not, however, with reference to flash nor complete absence of color. It refines very easily and gives a very fine grade of burning oil.

Of course, the proportions of products will be somewhat different on a refining scale (1,000 barrels)probably larger, rather than smaller, than is given on the small scale.

This petroleum is different from any of the numerous specimens that I have previously examined from the Wyoming territory.

A large amount of very light gasoline can be separated by strong cooling.

With respect to the large proportion of gasoline and of burning oil, also of paraffin, this petroleum is one of the most valuable that I have everexamined.

'It is a nonsulphur oil; percentage of sulphur, 0.03 .

Very little lubricating oil can be obtained, and that only light, $28^{\circ}$ to $30^{\circ}$, as the oil begins to crack at $350^{\circ}$ or less and will not stand higher distillation for the manufacture of heavier oils.

The paraffin in this oil is 6.2 per cent of the weight of the crude oil-more than is usually found in American petroleum. 
RÉSUMÉ OF OIL SITUATION, WITH SUGGES'IIONS.

The best oil territory in this region is between the axis of the Lazeart syncline and the outcrop of the oil-bearing shales west of the Meridian anticline (Pl. XI). The oil-beuring horizon is low in the Benton, and the oil is of high grade; carrying a large percentage of illuminants and a paraffin base.

The whole territory underlain by the Benton shales may be expected to yield oil of the same character as that found at Spring Valley, and a considerable oil field is thus outlined. Present developments indicate that the quantity obtained will increase toward the axis of the Lazeart syncline.

A single well has shown the presence of lower oil horizons yielding heavy lubricating oil. These are probably Jurassic, and prospecting for them should first be carried on along the Meridian anticline. Success at this point would suggest that similar developments be undertaken west of Rock Creek.

In developing this section wells should preferably be placed in valleys, first, because such locations will save much needless drilling; second, because a water supply can often be obtained in shallow bored wells in such locations; and third, because supplies can be transmitted more cheaply.

Between the Absaroka fault and the Rock Creek-Needles anticlinal this principal oilbearing horizon is in general either deeply buried or absent and is not of probable economic importance.

West of the Rock Creek-Needles anticlinal the rocks are all older than the Benton oilbearing shales, with the exception of the Evanston and Tertiary beds, which are not oil bearing.

\section{UNDERGROUND WATERS.}

The coarse beds in the Wasatch have yielded flowing water in several wells near Fossil and in Betty's well between Evanston and Hilliard. The Wasatch beds here have been tilted into a gentle syncline by movements along the Absaroka fault and the Rock CreekNeedles anticlinal. In all deep valleys between these two structural features similar flowing wells are to be expected (Pl. XI). At Fossil the water is brackish and of no evident economic importance. . At Betty's well, however, it is reported of good quality, and similar flowing water may confidently be expected throughout that portion of Bear River Valley and in Needle, Goodwin, and Yellow creeks. In the bottoms along Bear River it will develop a very considerable head. 


\section{SURVEY PUBLICATIONS ON COAL, LIGNITE, AND PEAT. ${ }^{a}$}

The more important United States Geological Survey publications on coal, lignite, and peat are listed below. Those immediately following deal with coal:

ARnold, R. Coal in Clallam County, Wash. In Bulletin No. 260, pp. 413-421. 1905.

Ashley, G. H. The eastern interior coal field. In Twenty-second Ann. Rept., pt. 3, pp. 265-305. 1902.

1904.

The Cumberland Gap coal field of Kentucky and Tennessee. In Bulletin No. 225, pp. 259-275.

Coal in the Nicholas quadrangle, West Virginia. In Bulletin No. 260, pp. 422 428. 1905. and Glenn, L. C. Geology and mineral resources of part of the Cumberland Gap coal field, Kentucky. In Professional Paper No. 49, pp. 1-225, 1906.

BaIN, H. F. The western interior coal field [Iowa, Missouri, and Kansas]. In Twenty-second Ann. Rept., pt. 3, pp. 333-366. 1902.

Branner, J. C. The coal fields of Arkansas. In Mineral Resources U. S. for 1892, pp. 303-306. 1893.

Burrows, J. S. The Barnesboro-Patton coal field of central Pennsylvania. In Bulletin No. 225, pp. 295-310. 1904.

Burrs, C. Coal mining along the southeastern margin of the Wilmore basin, Pennsylvania. In Bulletin No. 225, pp. 325-329. 1904.

381. 1905 .

CAM PBELL, M. R. Geology of the Big Stone Gap coal field of Virginia and Kentucky. In Bulletin No. 111, pp. 13-106. 1893 .

1903.

'The Deer Creek coal field, Arizona. In Bulletin No. 225, pp. 240-258. 1904.

"The Meadow Branch coal field of West Virginia. In Bulletin No. 225, pp. 330-344. 1904.

Campielt, M. R., and ITAseltine, R. M. The northern Appalachian coal field. In Twenty-second Ann. Rept., pt. 3, pp. 119-226. 1902.

Campbelt, M. R., and Mendenhall, W. C. Geologic section along the New and Kanawha rivers in West Virginia. In Seventeenth Ann. Rept., pt. 2, pp. 473-511. 1896.

CHance, H. M., Anthracite coal mining. In Mineral Resources U. S. for 1883 and 1884, pp. 104-143, 1885.

DARton, N. II. Coal of the Black Hills, Wyoming. In Bulletin No. 260, pp. 429-433. 1905.

DAY, W. C. The coal and pitch coal of the Newport mine, Oregon. In Nineteenth Ann. Rept., pt. 3, pp. 370-376. 1899 .

Diller, J. S. Coal in Washington, near Portland, Oreg. In Bulletin No. 260, pp. 411-412. 1905. - The Coos Bay coal field, Oregon. In Nineteenth Ann. Rept., pt. 3, pp. 309-376. 1899.

Fisuer, C. A. Coal fields of the White Mountain region, New Mexico. In Bulletin No. 225, pp. 293294. 1904.

- Coal of the Bighorn Basin in northwest Wyoming. In Bulletin No. 225, pp. 345-362. 1904. Forrester, R. Coal fields of Utah. In Mineral Resources U. S. for 1892, pp. 511-520. 1893 .

Fuller, M. I., and AsHLEY, G. H. Recent work in the coal field of Indiana and Illinois. In Bulletin No. 213, pp. 284-293. 1903.

Griswold, W. T. Pittsburg coal in the Burgettstown quadrangle. In Bulletin No. 260, pp. 402-410. 1905.

HaSeltine, R. M. The bituminous coal field of Ohio. In Twenty-second Ann. Rept., pt. 3, pp. 215226. 1902.

Hayes, C. W. The coal fields of the United States. In Twenty-second Ann. Rept., pt. 3, pp. 7-24. 1902.

The southern Appalachian coal field. In Twenty-second Ann. Rept., pt. 3, pp. 227-263. 1902 Coal fields of the United States. In Bulletin No. 213, pp. 257-269. 1903.

IIILLS, R. C. Coal fields of Colorado. In Mineral Resources U. S. for 1892, pp. 319-365. 1893. 
KEyes, C. R. Sketch of the coal deposits of Iowa. In Mineral Resources U. S. for 1892, pp. 398-404. 1893.

KNIGHT, W. C. Coals and coal measures of Wyoming. In Sixteenth Ann. Rept., pt. 4, pp. 208-215. 1895 .

LANE, A. C. Tr.e Northern interior coal field. In T'wenty-second Ann. Rept, pt. 3, pp. 307-331, 1902.

MCCreatit, $\therefore$ s., and D'Invilliers, E. V. The Clinch Valley coal field. In Mineral Resources U. S. for 1892 , pp. 521-528. 1893.

PArker, E. W. Coal. In Mineral Resources U. S. for 1894, pp. 1-217. 1896.

— Coal. In Mineral Resources U. S. for 1902, pp. 289-447. 1904.

- Coal. In Mineral Resources U. S. for 1903, pp. 351-538. 1904.

_- Coal. In Mineral Resources U. S. for 1904, pp. 381-577. 1905.

— Coke. In Mineral Resources U. S. for 1902, pp. 449-515. 1904.

- Coke. In Mineral Resources U. S. for 1903, pp. 539-608. 1904.

- Coke. In Mineral Resources U. S. for 1904, pp. 579-648. 1905.

SAFFord, J. M. 'The T'ennessee coal measures. In Mineral Resources U. S. for 1892, pp. 497-506. 1893 . Smiti, E. A. The coal measures of Alabama. In Mineral Resources U. S. for 1892,pp. 293-300. 1893.

Smith, G. O. The coal fields of the Pacific coast. In Twenty-second Ann. Rept., pt. 3, pp. 473-513. 1902.

Spurr, J. E. Coal deposits befween Silver Peak and Candelaria, Esmeralda County, Nev. In Bul!etin No. 225, pp. 289-292. 1904.

Stoek, TI. 1. The Pennsylvania anthracite coal field. In Twenty-second Ann. Rept., pt. 3, pp. 55117. 1902.

Stone, R. W. The Elders Ridge coal field, Pennsylvania. In Bulletin No. 225, pp. 311-324. 1904. STorns, I. S. The Rocky Mountain coal fields. In Twenty-second Ann. Rept., pi. 3, pp. 415-471. 1902.

TAFr, J. A. Geology of the McAlester-Lehigh conl field, Indian Territory. In. Nineteenth Ann. Rept., pt 3, pp. 423-583. 1899.

- Preliminary report on the Camden coal field, of southwestern Arkansas. In Twenty-first Ann. Rept., pt. 2, pp. 313-329. 1900.

The southwestern coal field. In Twenty-second Ann. Rept., pt 3, pp. 367-413. 1902.

- Maps of segregated coal lands in the McAlester district, Choctaw Nation, Indian Territory, with descriptions of the unleased segregated coal lands. U. S. Dept. of the Interior, Circular No. 1. 59 pp. 1904.

- Maps of segregated coal lands in the Wilberton-Stigler district, Choctaw Nation, Indian 'Territory, with descriptions of the unleased segregated coal lands, U. S. Dept. of the Interior, Circular No.2. 47 pp. 1904 .

- Maps of segregated coal lands in the Howe-Poteau district, Choctaw Nation, Indian Territory, with descriptions of tho unleased segregated coal lands, U. S. Dept. of the Interior, Circular No. 3. 48 pp. 1904.

Maps of segregated coul lands in the McCurtain-Massey district, Choctaw Nation, Indian Territory, with descriptions of the unleased segregated coal lands, U. S. Dept. of the Interior, Circular No. 4.54 pp. 1904.

Maps of segregated coal lands in the Lehigh-Ardmore district, Choctaw Nation, Indian Territory, with descriptions of the unleased coal lands, U. S. Dept. of the Interior, Circular No. 5. 39 pp. 1904.

Progress of coal work in Indian Territory. In Bulletin No. 260, pp. 382-401. 1905.

TAFF, T. A., and $A D \Lambda M S$, G. T. Geology of the enstern Choctaw coal fields, Indian Territory. In 'T'wenty-first $\Lambda \mathrm{nn}$. Rept., pt. 2, pp. 257-311. 1900.

VAUGHaN, I. W. Reconnaissance in the Rio Grande conl field of Texas. Bulletin No. 164. $100 \mathrm{pp}$. 1900.

Wevks, J. D. The manufacture of coko. In Mineral Resources U. S. for 1883 and 1884, pp. 144-213. 1885.

- The manufacture of coke. In Mineral Resources U. S. for 1894, pp. 218-304. 1896.

Write, D. The bituminous coal field of Maryland. In Twenty-second Ann. Rept., pt. 3, pp. 201-214. 1902.

White, D., and Campbell, M. R. The bituminous coal field of Pennsylvania. In Twenty-second Ann. Rept., pt. 3, pp. 127-200. 1902.

WhiTE, I. C. Stratigraphy of the bituminous coal field of Pennsylvania, Ohio, and West Virginia. Bulletin No. 65. 212 pp. 1891.

Wiltis, B. Some conl fields in Puget Sound, Washington. In Eighteenth Ann. Rept.,pt. 3, pp. 399436. 1898 .

Winsiow, $\Lambda$. The conl measures of Missouri. In Mineral Resources U. S. for 1892, pp. 429-436. 1893.

Woobworti, .T. B. The Atlantic const 'Triassic coal field. In 'T'wenty-second Ann. Rept., pt. 3, pp. 25-53. 1902 . 
The following publications contain, in the main, brief references to the coal deposits of the regions of which they treat. In some cases, however, the articles devote a large portion of space to the treatment of this subject:

Becker, G. F. Report on the geology of the Philippine Islands. In Twenty-first Ann. Rept. pt. 3, pp. 493-625. 1901.

DiLler, J. S. A geological reconnaissance in northwestern Oregon. In Seventeenth Ann. Rept., pt. 1, pp. 447-520. 1896 .

Eldridge, G. H. A geological reconnajssance across Idaho. In Sixteenth Amn. Rept., pt. 2, pp. 211276. 1855 .

- A geological reconnaissance in northwest Wyoming. Bulletin No. 119.72 pp. 1894.

Lmmons, S. F., Cross, W., and EldredGe, G. H. Geology of the Denver basin. Monograph XXviI. 556 pp. 1896.

Punington, C. W. Preliminary report on the mining industries of the Telluride quadrangle, Colorado. In Eighteenth Ann. Rept., pt. 3, pp. 751-848. 1898.

RUSSELL, I. C. A preliminary paper on the geology of the Cascade Mountains in northern Washington. In Twentieth Ann. Rept., pt. 2, pp. 89-210. 1900.

Shaler, N. S., and Woodworth, J. B. Geology of the Richmond basin, Virginia. In Nineteenth Ann. Rept., pt. 2, pp. 385-520. 1899.

SHALER, N. S., WoOdworth, J. B., and Foerste, A. F. Geology of the Narragansett basin. Monograph XXXIII. $402 \mathrm{pp.} 1899$.

Sмiтн, G. O., and White, D. The geology of the Perry basin, in southeastern Maine. Professional Paper No. 35. 107 pp. 1905.

Stone, R. W. Mineral resources of the Elders Ridge quadrangle, Pennsylvania. Bulletin No. 250. 86 pp. 1905.

On pages 8-13 of this bulletin is given a list of geologic folios with the mineral resources briefly described. The following folios contain references to coal: Nos. $1,2,4,6,8,9,12$, $17,19,21,22,24,25,26,28,33,35,40,44,45,47,49,53,54,58,59,60,67,68,69,71,72$, $73,77,79,82,84,89,92,94,102,105,106,107,110,115,121$, and 123 .

The following publications are the most important on peat and lignite:

Burchard, E. F. Lignites of the middle and upper Missouri valley. In Bulletin No. 225, pp. 27C288. 1904.

KNowlton, F. I.. Fossil wood and lignite of the Potomac formation. Bulletin 56. 72 pp. 1889. Shalfer, N. S. Origin, distribution, and commercial value of peat deposits. In Sixtcenth $\Lambda \mathrm{m}$. Rept., pt. 4, pp. 305 314. 1895 .

Willis, B. The lignites of the Great Sioux Reservation, Dakota. Bulletin No. 21. 16 pp. 1885. 